



\section{A REVIEW}

$$
\text { OF THE }
$$

\section{NON-MARINE FOSSIL MOLLUSCA}

$$
\text { OF }
$$

NORTH AMERICA.

$$
\begin{aligned}
& \text { c. A. Lwніте, м. D. } \\
& \text { Matthew Library }
\end{aligned}
$$


cat. for Pales lib. 


\section{IETTER OF TRANSMITTAL.}

SIR: In accordance with your request that I should prepare an article for your annual report upon a subject which has for some years been engaging my attention, I have the honor to submit herewith the following, which I have entitled "A Review of the Non-Marine Fossil Mollusca of North America."

In the preparation of this article I have endeavored as fully as practicable to follow your suggestion, that it should be as free from technical forms and methods as the nature of the subject will allow. I have therefore endeavored to address the general reader rather than the special investigator; but $I$ have given copious references in the form of foot-notes, so that those who wish to pursue the subject further may readily refer to nearly all that hás been published upon it in America.

Your recognition of the fact that there is a natural and growing desire on the part of intelligent readers to know something of the geological history of the predecessors of the animals with which they are more or less familiar, or which are frequently referred to in the books they read, would be expected by those who are familiar with the graphic style of your own writings; and your wish to gratify that desire is too obviously correct to make any explanation or apology proper on the part of a specialist who may be called upon to communicate with the public in the form proposed by you.

In the selection of a subject, I have chosen one which, although primarily based upon molluscan species which are all extinct, embraces the consideration of, or reference to, living forms, congeners of those which have ceased to exist, that are scattered over all parts of the country. It is, therefore, a subject which a far greater number of persons will find of ready application within their every day experience than many others which the wide range of paleontology might furnish. In illustrating this subject on the accompanying plates, I have in each case selected such figures (which are in part copies of illustrations already published by various authors, but largely newly drawn from the type-specimens of the various species) as would exhibit the form, and such features of the objects, respectively, as strike the eye of the ordinary observer, omitting, in many cases at least, those details of structure which more especially engage the attention of the special investigator. 
While the material upon which the present statements and discussions are based is in many respects very incomplete, it is nevertheless extremely suggestive and instructive, and a knowledge of it is sure to awaken a strong interest in future labors in the same field that has been fruitful of these results.

A majority of the illustrations accompanying this article have been drawn directly from specimens in the United States National Museum, permission having been kindly given to do so by Professor Spencer F. Baird, the Director of the museum. A large part of the specimens thus used are the original types of the species which are illustrated.

. The drawings have been made with pen and ink by Dr. J. C. McConnell, of Washington, and they have been reproduced by the photoengraving process.

Very respectfully,

Hon. JoHN W. Powell,

O. A. WHITE.

Director of the United States Geological Survey. 


\section{CONTENTS.}

Letter of transmittal............................................. 405

Introductory remarks........................................... 411

Annotated and illustrated catalogue.... ............................ 420

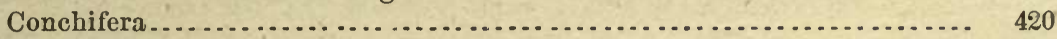

Ostreilææ............................................... 420

Anomiida........................................... 421

Mytilidæ.............................................. 423

Unionidx............................................ 424

Cyrenidæ.............................................. 435

Pisidiidæ.............................................. 440

Corbulidæ............................................. 441

Gasteropoda .............................................. 443

Auricnlidæ........................................... 443

Limnæidæ............................................. 444

Physidø................................................ 449

Ancylidæ ............................................... 451

Vitrinidæ................................................ 452

Arionidæ........................................... 452

Helicidæ.............................................. 453

Pupidæ...................................................... 455

Succinidæ............................................ 457

Neritidæ................................................. 457

Cerithidæ............................................. 459

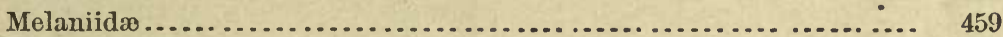

Ceriphasiidæ.......................................... 462

Rissoidæ.............................................. 465

Viviparidæ............................................. 466

Valvatidæ............................................. 470

Tabular view of the non-marine fossil mollusca of North America.......... 472

Spurious and doubtful species..................................... 478

General discussion........................................... 479 



\section{ILLUSTRATIONS.}

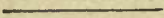

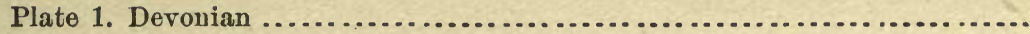

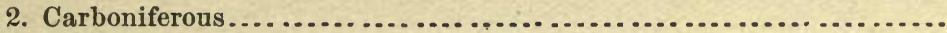

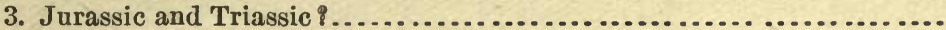

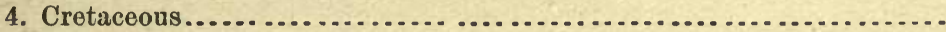

5. Cretaceous.....

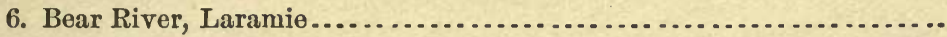

7. Bear River, Laramie......................................

8. Bear River, Laramie ..........................................

9. Laramio

10. Laramio

11. Laramio

12. Laramio

13. Laramie

14. Laramie

15. Laramio

16. Laramie

17. Laramie

18. Laramie

19. Laramio

20. Laramio

21. Laramio

22. Laramie

23. Laramio

24. Laramie

25. Laramio

26. Laramie

27. Laramio

28. Eocene

29. Eocene

30. Eocene

31. Eocene

32. Miocene and Pliocene?. 



\title{
A REVIEW OF THE NON-MARINE FOSSIL MOLLUSCA OF NORTH AMERICA.
}

\author{
By C. A. White, M. D.
}

\section{INTRODUCTORY REMARKS.}

In this article I propose to review the principal known facts concerning the fossil fresh-water, brackish-water, and land mollusca of North America, taking up each family in the order of systematic classification, and tracing the history of its occurrence, so far as it has been learned, from the earliest known appearance of any of its species within the present limits of North America until the present time; and to follow the same with some general discussion of certain questions that are suggested by the facts thus set forth. For the purpose of giving an approximately chronological view of the different faunæ the figures are arranged on the plates under headings that indicate the successive geological periods to which they belong. The plan proposed involves at least brief mention of every species of non-marine fossil mollusca yet discovered in North America, and the illustration of nearly all of them by figures, which show their external form and leading features, so far as they are known. To avoid frequent repetition, it is mentioned here that all statements made in this article in regard to the range of families and genera in time, must be understood as applying to North America alone, unless it is otherwise expressly stated.

The scope of this article, as indicated by the title and foregoing remarks, is a very wide one; and the presentation of such a title would seem to imply the known existence of much material upon which to base a discussion of the subject. Lest I should seem to assume greater knowledge of this subject than the facts will warrant, it may be stated that while the material upon which our present knowledge of it is based is really considerable and very important, it is nevertheless true that as regards a continuous history of the faunæ herein discussed, and the geological epoch in which our most common living molluscan types really originated, our knowledge is very imperfect. Enough material, however, has been collected to throw much light upon the character of the ancestral representatives of many of the families which are herein mentioned. It is proposed to go so far only in the discussion of these 
fossil forms as we are warranted in doing by the well-ascertained character of the evidence adduced.

As to the scope of the general subject, although it embraces the three categories of non-marine mollusca, namely, those of brackish-water, fresh-water, and land habitat, it is still small as compared with that of the great mass of that portion of the molluscan subkingdom which is embraced by the marine mollusca. Not only is the diversity within the three categories of molluscan forms which are herein discussed almost incomparably less than that which obtains among marine mollusca, but a greater proportion of the remains of formerly existing non-marine than of marine mollusca, have almost certainly been destroyed as the result of geological changes and other causes which will be suggested, or they have failed to be preserved in an available condition for study. Therefore the record furnished by the fossil non-marine mollusca is much more imperfect than it is in the case of the marine mollusca. Still, the scope of this subject is a very broad one, even with our present incomplete knowledge of its details, and the discussion of many interesting points pertaining to it must be deferred to other occasions.

Again, while the three non-marine categories of mollusca, especially the first two, in the order in which they have been named, may be defined from each other with a good degree of accuracy in the case of their jiving representatives, yet it has not always been found easy to say whether some of those fossil forms whose nearest living congeners are found exclusively in perfectly fresh-water may not have lived in waters which contained at least a small proportion of salt; but this subject will be further referred to on subsequent pages. Neither are we positive in all cases that those species which we refer to a land habitat were really land pulmonate mollusks, or that they may not have been in some cases palustral pulmonates, or, possibly, gill-bearing mollusks. But generally these determinations are made with much confidence, based upon the known correlation of shell characteristics with the soft parts of the living moliusks which formed them.

The more indefinite boundary of the scope of the present article is that which $I$ have drawn between the brackish-water and marine forms. The difficulty of drawing such a line arises largely from the fact that some of the genera which have more or less abundant representatives in brackish waters have also representatives in marine waters; but I have regarded those strata as of brackish-water origin, which have been found to contain by natural deposition forms whose living congeners are found in brackish waters, even though such fossil forms are found associated with those on the one hand whose living congeners are sometimes, but not not always, found in marine waters; or, on the other hand, with those whose living representatives are known only in fresh waters. Such a commingling of forms as is here indicated really occurs in numerous instances, especially in the strata of the Laramie group. Thus theassociation in one and the same stratum of Corbicula, Corbula, Neritina, 
\&c., is held to indicate a brackish-water origin for such a stratum, even though it holds, associated with those shells, such forms as Unio, Viviparus, Goniobasis, \&c., especially if such strata alternate (as is often the case in the Laramie Group) with strata which contain on the one hand only such fresh-water forms as Unio, Viviparus, \&c., and on the other hand such saline-water forms as Ostrea, Anomia, \&c. This view is also confirmed by the fact that in the Laramie Group Corbicula, Corbula, and Neritina are frequently found so associated with Ostrea and Anomia as to plainly indicate that they all lived together. It is thus clearly shown that a part of the forms discussed in this article have near allies in strata of marine origin, and also many near allies now living in truly marine waters, and none in fresh waters; but the commingling of these fossil species of undoubted saline habitat with others which clearly indicate that they lived in water of far less than marine saltness, makes it necessary to regard the former as members of a brackish-water fauna, and, therefore, as coming within the scope of this article.

In some cases the brackish waters that, by the presence in the deposits they have left of such fossils as have been referred to, are indicated as having then prevailed, were plainly those of estuaries, which indented the coasts of formerly existing seas at the mouths of then existing rivers. But the greater part of the species enumerated in this article, which are regarded as having had a brackish-water habitat, come from strata (namely, those of the Laramie Group) which bear evidence of having been deposited in a great inland sea, in parts of which sea brackish waters alternated with fresh, or nearly fresh-waters. The facts upon which this conclusion is based have been presented in other publications, and are repeated to some extent upon following pages in this article.

Before proceeding with the enumeration of the specific forms of non-marine mollusca which have been discovered in North American strata, and the geological position which each fauna represented by them respectively occupies, it is necessary to present a brief tabular statement of the arrangement or order of the geological formations, beginning not with the earliest known fossiliferous rocks in the geological series, but with the formation which has furnished the earliest known molluscan forms that come within the scope of this article, namley, Devonian.

This tabular view of the formations has been made with especial reference to those which have been recognized in Western North America, because it is there that the greater part of the fossils have been collected which are discussed in the following pages.

It may not be entirely unnecessary to state that, although the terms group and formation are somewhat variously used by different writers, the strata that were formed in a period or epoch of geological time are usually and properly referred to by the same name as that of the period or epoch in which they were formed. Thus, the following table of geo. logical time is really a table of the formations that were produced dur ing that time. 
Subdivisions of geological time.

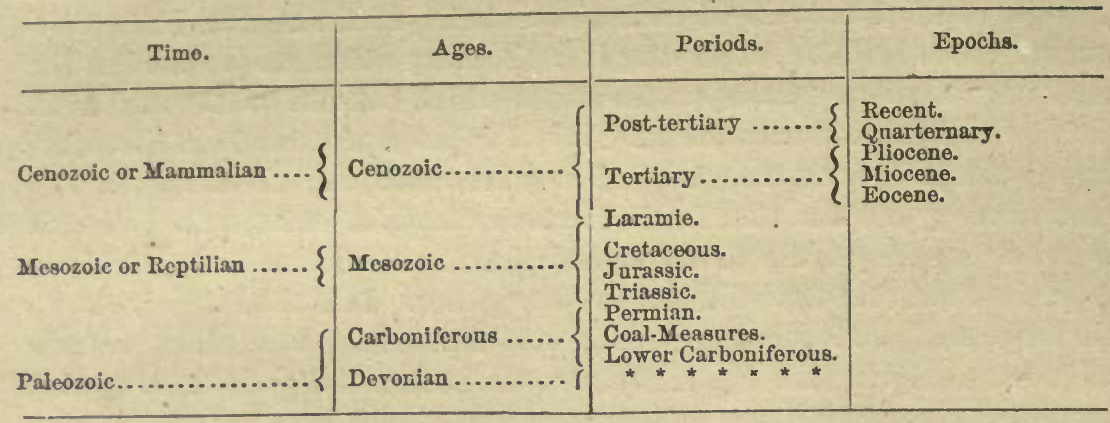

No special explanation of the terms or names used in this table, with perhaps the exception of Laramie, is deemed necessary, because they are to be found in all text-books of geology now in use; but some supplementary explanation of the terms that, in connection with those which have become so commonly known, have been used by the various geologists who have made original investigations in Western North America is necessary to enable the general reader to understand clearly the use of them that is made in the following pages.

The term Laramie Group, although it is unknown except in the geology of Western North America, will be mentioned oftener perhaps in this article than the name of any other formation; because a greater number of the species herein mentioned come from that group of strata than from any other. This name is applied to a large and very important formation which, in the western part of the continent, comes between the wellrecognized marine Cretaceous strata below, and the equally well-recognized Tertiary strata above. Geologists are not agreed as to whether this great group should be referred to the Tertiary or Cretaceous period, some contending for the former and some for the latter reference. The truth appears to lie between the two opinions, and I have elsewhere presented reasons for regarding this group as occupying a transitional position between the Cretaceous and Tertiary.* Neither the Laramie Group nor any true geological equivalent of it is at present known anywhere except in Western North America. It there occupies or is found at various localities within a large region, the present known limits of which may be roughly stated as extending from Northern New Mexico on the south to the British possessions on the north, and from the vicinity of Great Salt Lake on the west to a present known distance out upon the Great Plains of more than 200 miles from the eastern base of the Rocky Mountains. It has been traced within tlre western boundary of both Kansas and Nebraska.

In the course of the earlier geological investigations which were made in the west, the strata of this great group, which represents a distinct

\footnotetext{
An. Rep. U. S. Geol. Sur. Ter. for 1877, pp. 259-265. Ib. for 1878, part I, pp. 51, 52.
} 
period in the geological history of North America, were studied independently by different investigators, at various more or less widely-separated localities within the region that has just been indicated, which resulted in the strata of that group receiving different names in different regions. Thus, Meek \& Hayden gave the name "Judith River Group" to those strata in the valley of the Upper Missouri, near the mouth of Judith River, which were found tocontain brackish-water fossils. They gave the name "Fort Union Group" to strata of similar faunal character near Fort Union, also in the valley of the Upper Missouri, but at a considerable distance to the eastward of the Judith River region. They also gave the name "Lignitic Group" to those strata in Colorado east of the Rocky Mountains which were found to contain a similar fauna. Professor Powell, studying the strata in Wyoming and Utah, gave the name "Point of Rocks Group" to a series which agrees mainly with that which is now called Laramie, and which had been referred to by Meek \& Hayden as the "Bitter Creek Coal series." The strata which are herein called the Bear River Laramie beds of Southwestern Wyoming and the adjacent parts of Utah were by Meek and Hayden generally referred to as the "Bear River Estuary beds." Mr. King was the first to place all these local groups together (except those of the Upper Missouri River region) under the general and comprehensive name of Laramie Group. I subsequently showed that the Judith River, Fort Union, Lig. nitic, and Point of Rocks groups are all connected together by specfiic identity of fossils in their respective strata.* I have therefore treated the strata of all those different regions respectively as only local derelopment of parts of one great group; but I lave retained the local names which they originally received from different authors, only substituting the word "beds" in most of those cases for that of "group," using the latter term in the more comprehensive sense. Thus, I speak of the Judith River beds, Fort Union beds, Bear River beds, \&c., while referring them all to the great Laramie Group.

A similar duplication of names, arising from similar circumstances, also exists in reference to the earlier or earlist members of the purely fresh-water Eocene series, which immediately succeeds the Laramie Group. Thus, the names "Wahsatch Group" of Hayden, "Vermilion Creek Group" of King, and "Bitter Creek Group" of Powell are regarded as substantially equivalent, or as representing one and the same division of the Eocene epoch.

To aid the reader, who may be assumed to be unfamiliar with the details of western geology and with the names which the different series of strata in the West that are necessarily often referred to in this article lave received from different investigators, the following summary of facts and opinion is giren:

1. The "Judith River Groul," "Fort Union Group," "Lignitic Group," 
"Bitter Creek Coal series," "Point of Rocks Group," and "Bear River Estuary beds"* are all parts of the great Laramie Group.

2. The Laramie Group is regarded as a transitional group between the Cretaceous and Tertiary series, and therefore as representing a period partaking of both the Mesozoic and Cenozoic ages.

3. The "Wahsatch Group," "Vermilion Creek Group," and "Bitter Creek Group" are regarded as at least approximately equivalent strata, constituting the oldest member of the purely fresh-water Eocene Tertiary series of deposits in the West.

4. The Green River and Bridger Groups are respectively the second and third nembers of that fresh-water Eocene series.

5. The Wind River Group of Wyoming is regarded as of Eocene age.

6. The White River Group of Dakota is regarded as of Miocene age.

7. The fresh-water deposit of the Kawsoh Mountains, in Northern Nevada, and its equivalent in Southern Idaho, called by King the Truckee Group, are regarded as of Miocene age.

8. No strata of Pliocene age are referred to in this article except those of Cache Valley, in Northern Utah, because with that exception no non-marine mollusca are known to have been obtained from any North American strata which may be referred to that epoch; unless certain forms of Physa be also excepted, which have been found in the lBrown's Park Group of Powell, in Southern Wyoming.

Our knowledge of the various geological formations which are found within the limits of North America enables us to trace with a good degree of satisfaction the history of the evolution of the continent or the progressive steps by which it was elevated above the level of the sea. A brief outline, or at least a statement of some of the phases of this history, as it is understood by geologists, is necessary to a proper understanding of the facts which are presented in the following pages. Without going into the details of investigations by which geologists have arrived at their conclusions, it may be stated that the continent in its present shape has been produced by the coalescence of two or more principal portions which were elevated above the level of the sea in the earlier geographical ages in consequence of the progressive elevation of the continental area. The two principal portions of the continent previous to the Cretaceous period were an eastern and western one respectively, and before the close of that period they were separated by a broad stretch of open sea. By the continued slow rise of the whole continental area this broad stretch of open sea became land-locked at the close of the

\footnotetext{
* It should be remarked here that the molluscan species of the Bear River beds and their equivalents are all different from those of the Laramie Group clsewhere; but those strata are referred to the Laramie Group because they hold the same stratigraphical relation to the Cretaceous below and the Tertiary above that the typical Laramie strata do in other regions, and also because they contain a brackish-water fauna. Whether this difference in the faunæ is due to difference in age, contemporaneous isolation of waters as separate seas during the Laramie period, or to some other causo, is not jet known.
} 
Cretaceous period and beginning of the Laramie, changing the area thus inclosed to a brackish-water sea, in which the strata that we now call the Laramie Group were deposited. By the continued elevation of the continental area that sea became much reduced in size and entirely fresh at the close of the Laramie period.

During the immediately succeeding Eocene Tertiary epoch at least, - the great fresh-water lakes that were thus formed prevailed over a large part of that area which in the Laramie period had been occupied by brackish, and previously by marine, waters. Then began the series of movements in the earth's crust which resulted in the elevation of the plateaus and the great systems of mountains of Western North America, into the structure of which these Laramie and Eocene strata enter. Some portions of the western part of the continent continued to be occupied by fresh=water lakes of the kind last referred to, during the middle and latter portions of the Tertiary period; but they were much less in size than those which previously existed. They also gradually became smaller, and finally disappeared by being drained of their waters; or remuants of them remained to become the salt-water lakes of to-day.

The incompleteness of that portion of the geological record which is furnished by the fossil remains of the three categories of mollusks, which form the subject of this article, has already been referred to, and the causes of it are very apparent when it is remembered how small a proportion the non-marine have always borne to the marine mollusca; and also how small a proportion of fresh and brackish water deposits there must always have been in comparison with marine deposits.

The extensive fresh and brackish water deposits of Western North America are remarkable exceptions to the general rule, that extensive geological formations are of marine, or open sea, origin; and we have therefore in that region, and for the epochs which those formations represent, an unusually full record of non-marine and terrestrial life; for it must be remembered that those formations contain many remains of terrestrial vertebrates, and an abundant flora, as well as of fresh-water and land mollusca. . This statement of facts naturally leads to a brief consideration of the conditions which prevailed in former geological periods, and which conduced to the preservation of the molluscan forms herein discussed, when so large a proportion of their kinds in other parts of the world were destroyed.

While the remains of aqueous mollusca were readily entombed and preserved in the sedimentary deposits of the waters in which they lived (which deposits afterward became rocky strata), those of land mollusca must have been transported from the land into such waters, where alone they could have been preserved, and where in fact they did receive the same entombment with those that had lived there. This transportation of the shells of land mollusea was doubtless in most cases effected by the currents of rivers near the banks of which the mollusks lived, and into the waters of which they were swept in time of flood. And yet an 
unexpectedly large proportion of the known fossil pulmonate mollusca are those whose kabitat was constantly upon the land. The conditions, howerer, which prevailed during the Coalmeasure period of the Car. boniferous age, and under which the immense quantities of vegetable material that we now know as coal were preserved, were necessarily somewhat favorable to the preservation of such land mollusca as may have found a habitat among that vegetation. The paucity of the remains of such mollusca that have yet been discovered in the extensive coal-bear, ing strata of that early period seems to prove that they could not then have been very abundant; but the discoveries of Dawson, Bradley, and Whitfield show conclusively that a well-developed and widely differentiated land moluscan fauna existed at least as early as the middle of the Carboniferous age, and probably much earlier.

From the Coalmeasure period until that of the Laramie the fer remains of non-marine mollusca that have been found in North American strata present indications that the layers in which they were discovered were deposited under estuary, palustral, or limited lacustrine conditions, reference to which will be made in connection with the separate mention of the species on following pages. The conditions which prevailed in Western North America during the Laramie and Eocene periods have already been indicated, and for fuller details the reader is referred to the works before cited.

Although there are really many facts now known which throw light upon the physical conditions that prevailed, and the mollusean faunæ which lived in Western North America during the various geological periods from the later Paleozoic to the present time, a part of which have been referred to, the following counter-facts should also be mentioned, because they show how far from perfect or continuous the geological record really is, in relation especially to the non-marine mollusea.

Rivers, ponds, and marshes have necessarily existed ever since any considerable portion of the continent rose above the sea, and those rivers and ponds, without doubt, all had their own molluscan faunæ ever since the later portion of Paleozoic time, if not from a still earlier date, and yet no trace of any river deposits, except those of estuaries (and few of these are known), has yet been discovered which pertain to any geological epoch except that of the Post-Tertiary. The same can hardly be said of palustral deposits, because much, if not all, of the coal must have been produced under palustral conditions; and yet it is a note. worthy fact that the greater part of the known fossil palustral mollusca have been found preserved in lacustrine deposits together with mollusks of lacustrine origin, and very few in true palustral deposits.

Although it is only in the eastern half of the continent that any remains of non-marine mollusea have been found in strata of Paleozoic age, the remains of such mollusca as have been found there in strata of any of the periods between that of the Coalmeasures and the Post-Tertiary are few and unimportant.*

* See remarks on a following page on spurious and doubtful species. 
The same might also be said of that portion of the continent which borders upon the Pacific Ocean, and for the same periods, but for the very few Unione forms which the Cretaceous deposits have furnished there, and which have special interest in connection with other fossil Unionidæ mentioned in this article. Therefore, almost the whole of our present knowledge of the character of the non-marine molluscan types which existed during the whole of Mesozoic and Tertiary time aud of the order of their succession has been derived from discoveries of their remains which have been made in the interior region of the western half of the continent, mainly in connection with the surveys that have been prosecuted under the auspices of the government. Moreover, the discoveries that have been made in North America up to the present time give us very little information of any molluscan fauna, except the marine, for the Miocene epoch, and still less for the Pliocene. Therefore this review of the non-marine molluscan faunæ of the continent, although it is intended as a synopsis of all the species that are at present known, is something like a chapter, or parts of chapters, taken at random from a book; but these selections are of such a character as to give us a very good indication of what the whole book, figuratively speaking, must be. This indication is all the more clear because of the fact that while every species that is discussed in this article, from whatever formation it comes, is regarded as extinct, the great majority of the genera, and even the sections or subdivisions of the genera, are precisely the same as those which we find represented by living forms. In the case of many of the fossil forms, so clearly are these familiar generic and subordinate types expressed, that the fossil species are often found to resemble those now living so closely as to require careful scrutiny to discover wherein they differ. This persistence through long periods of geological time, of even the simpler types of non-marine mollusks, after they were once established, is a remarkable and interesting fact. Individuals, generations, and species died, as the epochs succeeded each other, but the types* have remained to this day.

* The word "type," as used by different authors, has often necessarily a somewhat indefinite meaning; but as used in this article it may be defined as an ideal representation of the essential characteristics of a group of species, usually applied to a group which may embrace a genus, or only a subordinate division of a genus. In the latter case, I use the designation subordinate type. I do not use the term type in any case as interchangeable with any of the names that are used in systematic classification, such as species, genus, family, \&c. ; but sometimes it may be equivalent in scope with any of them; as, for example, when only a single species of a subgenus, genus, or family is known.

Thus, although types may have no material existence in one sense, they are found to have been more persistent in time or duration than specific forms; for we find that many of the types, as above defined, which now exist among living mollusca also existed in various geological epochs as far back as Mesozoic, or even earlier, time; but every known fossil species in which those types have been expressed have successively become extinct. 


\section{ANNOTATED AND ILEUSTRATED CATALOGUE.}

\section{CONCHIFERA.}

The families of the Conchifera, which are represented by the fossil species discussed in this article, are those only which are represented among the living non-marine mollusca; because, so far as we now know, there is not a single representative of an extinct family among all those species. Moreover, the principal genera are the same among both the fossil and recent forms, and in only a few cases at most is there a subgeneric difference, or even a difference in the subordinate types into which certain of the genera may be divided; although all the species are regarded as extinct.

It should be understood that this article is a review, and not a revision, of published species. Therefore, the genuineness of the different species which have been published by various authors is seldom called in question, even when it is doubted, as it is in a number of instances. It is thought best on this occasion to present the subject somewhat historically, and defer a critical revision of the species to another time.

OSTREIDAE.

Although the Ustreidæ of the present time are much less frequently found living in the waters of the open sea than in those of bays and estuaries, the fossil shells of all the various generic groups of that family are often found quite abundantly associated with those of such molluscan forms as must be regarded as having been denizens of the open sea. Indeed, both the Mesozoic genera Gryphoea and Exogyra seem to have been invariably of open-sea habitat; while Ostrea proper has, in all the Mesozoic and Cenozoic epochs, existed in both marine and brackish waters; but the last-named genus seems to have always been in past times the only representative of the Ostreidæ that has lived in brackish waters, while none of the family have probably ever lived in perfectly fresh waters.

The most noteworthy examples of the fossil brackish-water Ostreidx of North America, namely, those of the Laramie Group, occur in strata that contain no truly marine forms, but which are frequently found to closely alternate with other strata in which fresh-water and land mollusca prevail; and, indeed, there are often found associated with these shells of Ostrea those of species whose living representatives exist only in fresh waters. But as it is my intention to prepare a separate essay for a future report on all the fossil Ostreidæ of North America, little more than incidental reference will be made to this family in this article-even to those species of Ostrea which constitute parts of the brackish-water fauna herein discussed. Since, bowever, the molluscan fauna 
of the great inland brackish-water sea which existed during the Laramie period will be necessarily somewhat frequently referred to and briefly discussed on following pages, it is thought best to make the series of its illustrations the more complete by presenting a few figures of the more characteristic forms of its Ostreidæ, which will be found on Plates 9, 10, 11, and 12.

Five species of Ostrea* have been described and published by various authors from strata which are now regarded as belonging to the Laramie Group; but in view of the known wide range of variation among the species of this genus, and the actual discovery of many intermediate forms which connect at least a part of those supposed species together, it is now thought that the strictly specific forms of Ostrea which have been discovered in the Laramie Group do not number more than two or three at most. $\dagger$

It is interesting to note how closely some of these ancient species of Ostrea are allied to living forms, a good example of which is afforded by 0 . wyomingensis, as may be seen by comparing the figures of it on Plates 10,11 , and 12, with the shells of the common Ostrea virginica, now liv. ing so abundantly upon our Atlantic coast. So closely, indeed, are some of the fossil specimens like living ones that, but for their partially mineralized condition, the former might easily be taken for damaged examples of the living species.

While the Ostreidæ have formed a more or less prominent feature of all the molluscan faunæ whose remains are found in all the marine deposits from the Jurassic period to the present time, we have yet discovered no remains of the family in any North American strata of any of the epochs betreen the close of the Laramie period and the beginning of the Post Tertiary which can be properly referred to a brackish water origin. Therefore the consideration of this family as contributing any of its species to non-marine molluscan faunæ must cease in this article with the references that are made to the fauna of the Laramie Group.

Precisely similar remarks may be made concerning the genera Anomia, Corbicula, Corbula, and Neritina so far as regards the extinction of all the species of those genera in the waters of the Laramie Sea as a consequence of their becoming completely freshened at the close of that period; and, also, because of the non-discovery of any brackish water deposits of a later date than that period in which such remains may have been deposited.

\section{ANOMUIDE.}

Since among fossil faunæ Anomia is an almost constant associate and sometimes, as, for example, in many of the layers of the Laramie Group,

* These were named, respectively, Ostrea 8ubtrigonalis Evans \& Shumard; O. glabra Meek \& Hayden; $O$. arcuatilis Meek; $O$. insecuris White; and $O$. wyomingensis Meek. Examples of all these forms are figured on the plates accompanying this article.

t See remarks on this subject in Au. Rep. U. S. Geol. Sur. Terr. for 1877, p. 162. Also, ib. for 1878, Part I, p. 56 . 
apparently the only immediate associate of Ostrea, the same general remarks may be made concerning the Anomiidæ that have just been made concerning the Ostreidæ so far as they are applicable to the subject of this article. The earliest known North American species of Anomia have been found in Cretaceous strata, the greater part of them having by the different anthors who have described them been reported as associated with forms that must be regarded as of marine origin, but some of them are known to hare existed in the estuaries that indented the sea coasts of the Cretaceous period.

One estuary species, A. propatoris, White, was discovered by Mr. Meek in an interesting estuary deposit of Cretaceous age at Coalville, Northern Utah, where it was found associated with Cyrena, Unio, Valvata, Melampus? Physa, and also with some marine forms. It is represented on Plate 5. In the marine Cretaceous strata of the same neighborhood some imperfect examples of Anomia have been found which seem to be specifically identical with Anomia propatoris. If this identification is correct it seems to prove that the species in question ranged from marine to brackish waters. This supposition is a plausible one, because certain living species of mollusks are known to have a similar range of habitat.

Anomia propatoris is very closely like some of the various forms of A. micronema presently to be mentioned, and the former not improbably represents the latter species ancestrally.*

Two other species of Anomia only are known, which come within the scope of this article, both of which are found in the strata of the Laramie Group in Colorado and Wyoming; although it is by no means unlikely that other species existed in the brackish waters of all the epochs that have passed since the family was first established.. These two species are A. micronema and A. gryphorhynchus, Meek. They are both represented on Plate 12. Both are from the Laramie Group, and although in the same neighborhood they are selclom found associated in one and the same layer.

It has been the subject of frequent remark that not a single example of the under valve of either of the three species of Anomia herein noticed has ever been discovered, although hundreds of examples of the upper valves of at least two of the species has been obtained, at many different localities, in a good state of preservation. I was lately so fortunate however as to find in the Laramie strata of Northeastern Colorado several examples of the under valve of $A$. micronema, one of which is illustrated by Fig. 11, on Plate 12. That the under, or byssusbearing, valves of $A$. micronema at least have been so generally destroyed is due to the fact, first, of their extreme thinness, and, secondly, to the fact that, with the exception of a thin, porcelanous layer in the middle portion, the whole valve is composed of a prismatic layer, like

"Seo remarks in An. Rep. U. S. Geol. Sur. Terr. for 1878, Part I, p. 14, pl. 12, fig. 15. 
the shell of Pinna; the pearly layer, which gives such strength to the npper valve, being apparently entirely wanting in the lower. This prismatic layer breaks up into its component prisms with great facility. The characteristics of the under valve of $A$. micronema, as well as those of the upper valve, show it to be a true Anomia; thus presenting evidence of the great antiquity of the genus just as it exists to-day.

MYTILIDAE.

This family is rery sparingly represented in the brackish water strata of North America, and not at all, so far as is now known, in either any existing fresh waters, or in any strata of purely fresh-water origin; yet the family has representatives in some of the strata of all the geological ages, from the Paleozoic to the present time. The only genus of this family which has been recognized among the fossil collections from our brackish water strata is Volsella Scopoli; and all the examples of it that have been discorered in those strata are apparently referable to the subgenus Brachydontes Swainson.

Two species have been described from the Laramie Group of Wyoming and Colorado, namely Volsella (Brachydontes) regularis and $V$. (B.) laticostata White; ${ }^{*}$ both of which are represented on Plate 13.

An undescribed form of this genus is also known to exist in the Bear River Laramie beds of Southwestern Wyoming. At least one species, which is closely allied with those just mentioned as coming from the brackish-water strata, is known to exist in the marine Cretaceous strata of the same region in which those Laramie species occur, and it is not improbable that they are genetically related with each other.

The genus Dreissena Van Beneden, a living species of which is so common in certain of the rivers of Europe and Western Asia, and which genus is so abundantly and variously represented in the fresh-water Tertiary deposits of Eastern Europe, is not known to be represented in North America by a single species, either living or fossil. Neither is Adacna Eichwald known in North America, either fossil or recent, although so common in Eastern Europe and Western Asia, in brackish waters and brackish-water formations.

The genus Mytilus, although it is recognized by Meek in the marine Cretaceous strata of the epoch which immediately preceded the Laramie period, seems not to have survived in the brackish waters of that period as did Ostrea, Anomia, and Volsella.

In the foregoing discussion of the three families Ostreidæ, Anomiidæ, and Mytilidæ, representatives of which are now so abundant upon our marine coasts, it will be seen that especial reference has been had to the faunæ of the Laramie and other great groups of strata in the western portion of the continent. This arises from the fact which has already been stated or alluded to, that in the epochs represented by those groups, the conditions were, in that region, widely extended and

${ }^{*}$ An. Rep. U. S. Geol. Sur. Terr. for 1878, Part I, pp. 58, 59, pl. 25, figs. 3 \& 4. 
very favorable for the developement of brackish and fresh-water faunæ; while whatever of estuary deposits may have been made during the periods that have elapsed since paleozoic time in those regions which now constitute other portions of the continent, lave been nearly or quite destroyed by the geological changes that have occurred, or they have hitherto escaped discovery. Consequently, as has already been remarked in relation to the Ostreidæ, diseussion of not only the brackish-water representatives of these-three families, but of all brackishwater forms will cease in this article with the references that are made to the fauna of the Laramie period. Discussion of the fresh-water and land mollusea will be continued to a much later epoch by references to their fossil remains, because favorable and extensive fresh water conditions continued in Western North America long after the wide-spread brackish waters of the Laramie period had ceased there.

But even as regards these purely fresh-water and land molluscan families, few of their remains have yet been discorered which are referable to the epochs which passed between the Eocene and the present time. These deficiencies of the geological record and their zoölogical bearing will be made apparent as the different known faunæ are presented in their order on the following pages.

\section{UNIONIDAS.}

For various reasons, no family of non-marine fossil mollusea is of greater interest than the Unionidæ, especially since the discovery of the large number of species in the Mesozoic and Cenozoic strata of Western North America, and of the rich Unione fauna of the Tertiary deposits of Eastern Europe.

Although certain shells found in the Carboniferous and Devonian strata of Europe and America have been referred to the Unioniclx by different authors, the accuracy of such reference has been by others seriously questioned; and American paleontologists at least have of late years not generally recognized as belonging to that famliy any shells found in strata of earlier than Mesozoie time.* Prof. James Hall has, however, recently expressed the opinion that the two bivalve species, which were named by Vanuxem Cypricardites cattskillensis and $O$. angustata, respectively, $₫$ belong to the genus Anodonta; and that the Montrose and Oneonta sandstones (later Devonian) in which those species occur, were "deposited under estuary and fresh-water conditions."

Aside from the apparent Unione characteristies of these shells, and the other facts upon which Professor Hall bases the opinion he has expressed, the wide differentiation, which is now known to have become fully established among the Unionidæ, at least as early as the later portion of Mesozoic age, points to a very early period for the origin of the family.

* See remarks on a following page on spurious and doubtful species.

† See "Science" for December, 1880.

‡Vanuxem’s Rep. Geol.; 3d District, New York, p. 186. 
It is not improbable, therefore, that representatives of the Unionidæ existed as early as the later Devonian, as has been suggested by Professor Hall. This opinion, furthermore, is all the more probably correct, because of the known fact that a well developed land-molluscan fauna existed during the Coalmeasure period, and apparently also in the Devonian, all the known species of which are mentioned on the following pages and figured on accompanying plates. Although it may not be regarded as certain that the Cypricardites cattskillensis and $C$. anyustata of Vanuxem really belong to the genus Anodonta, copies of Vanuxem's original figures are given on Plate 1 , for the purpose of comparison.

Dr. J. W. Dawson, in his Arcadian Geology, second edition, describes seven species of edentulous bivalves from the Coalmeasure strata of Nova Scotia, under the generic name of Naiadites. He states his belief that they are the shells of brackish-water or fresh-water mollusks "allied to the Mytilidæ or Unionidæ." The shell structure, as given by Dr. Dawson, is like that of the Unionidæ and unlike that of the Mytilidæ. It seems, therefore, not improbable that at least a part of his species really belong to the Unionidæ. Three of those species, namely, Naiadites carbonaria, $N$. elongata, and $N$. lcevis, are represented on Plate 2, the figures being copies of Dr. Dawson's original illustrations in the work referred to.

If these Devonian and Carboniferous shells do not really belong to the Unionidæ, the earliest known members of that family now known to exist in North American strata are two or three species, specimens of which were collected by Prof. E. D. Cope in the valley of Gallinas Creek, New Mexico, from strata which he regarded as of Triassic age.* These shells belong unquestionably to the genus Unio proper, as is shown by the character of the hinge and the muscular markings. The outer prismatic layer of the shell which characterizes the Unionidæ is also well preserved on some of the specimens. One of these forms, which is figured on Plate 3, was described by Mr. Meek, $\dagger$ under the name of U. cristonensis, and specific names were also proposed for the two other forms, the specimens of which he deemed to be too imperfect for characterization. $f$ There are some reasons for regarding the strata from which these shells were obtained as of Jurassic instead of Triassic age, but further investigation is needed before such an opinion can be confidently expressed. The figure of $U$. cristonensis is drawn from one of the best of Mr. Meek's type specimens, but which is nevertheless very imperfect. The species has never before been figured.

While $U$. cristonensis is probably the most ancient published North American species of Unio, this portion of the subject onght not to be

*An. Rep. Expl. and Sur. west of the 100th meridian, for 1875, p. 81.

+ An. Rep. Expl. and Sur. west of the 100th meridian, for 1875, p. 83.

$¥$ These two names are respectively Unio gallinensis and $U$. terra-rubra; but the spec-

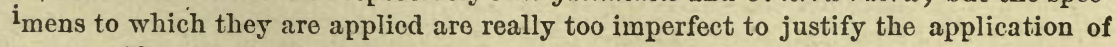
any specific names. 
passed over here without reference to the fact that Dr. S. G. Morton, Mr. T. A. Conrad, and Dr. Isaac Lea have all described fossil species which they regarded as belonging to the Unionidx. They were, however, either incorrectly referred to that family, or the formations from which they were respectively obtained are incorrectly stated; and they are, therefore, enumerated under the head of spurious and doubtful species on following pages.

That the Unionidæ existed within the area that now constitutes Western North America in the Jurassic period, and that the genus Unio of Retzius had then not only become established, but had reached a good degree of differentiation as regards the establishment of subordinate groups of forms within that great genus, is apparently beyond reasonable doubt; and in this article the question is treated as affirmatively settled. At the same time it should be stated that in the case of at least a majority of the alleged discoveries of fresh-water molluscan species in Jurassic strata, some doubt has been thrown upon the genuineness of the fresh-water origin of the strata in which they were deposited, or upon the actual Jurassic age of those strata.

The first discovery in North American Jurassic strata of shells which are referable to the Unionidæ was announced by Meek \& Hayden in connection with the publication of Unio nucalis, * which is figured on Plate 3. Those authors, howerer, expressed a remote doubt as to whether the strata in question, which occur in the vicinity of the Black Hills, are really of Jurassic age. No other examples of this species besides the type specimens have ever been discovered. They are shown to be those of true Unio by the hinge characters observable upon one of the specimens; and the outer prismatic shell-layer is observable on all of them. They were found associated with shells, which Meek \& Hayden referred to the genera Planorbis, Valvata, Viviparus, Neritella, and Lioplacodes respectively.

Another Jurassic species referable to this family is Unio stewardi, White, which was described from some imperfect specimens that were collected from Jurassic strata by Mr. J. F. Steward in Northern Utah.†

Fig. 1, on Plate 3 , is an outline illustration of this species which has been made up by help of several fragments, no perfect example having ever been discovered. It is believed to represent closely the outline and general aspect which the species presented while living. It is an interesting form, because it illustrates the fact that at least one of the subordinate types of Unio that now exists among the living species of the Mississippi River system was established at that early epoch.

The next known member of the Unionidæ, the appearance of which is to be mentioned in the order of geological time, is an interesting form

* Paleontology of the Upper Missouri, p. 92, pl. iii, fig. 13.

†Powell's Report, Geology of the Uinta Mountains, p. 110. 
which was described by Meek \& Hayden,* from Southeastern Dakota, under the name Margaritana nebrascensis. It was obtained from the Dakota Group, which is the earliest group of the Cretaceous strata in the North American series; and it was found associated with Cyrena dakotensis and Pharella? dakotensis of the same authors. These forms indicate a brackish-water, probably estuary, origin for at least the layers in which those fossils occur, although the remains of marine mollusca are found in other parts of the same group. Margaritana nebrascensis is represented by two figures on Plate 4, which figures are drawn from the principal type specimen.

In shape and general aspect this shell resembles some of the living forms of Margaritana, but it is of a somewhat different type from any known living species of that genus. It differs still more from any of the other known fossil Unionidæ, except the form which was described by Gabb $\uparrow$ from the Cretaceous strata of Vancourer's Island under the name of $U$. hubbardi. This suggestion of congeneric relationship is based upon the external characteristics alone which both present, because nothing is yet known of the character of the hinge of $U$. hubbardi. The hinge of $M$. nebrascensis, as ascertained by Meek, seems to warrant its reference to the genus Margaritana, and if this reference is correct, that species is, with the probable exception of the $U$. hubbardi of Gabb, the only known North American fossil form which can be properly referred to Margaritana. But, as before intimated, it probably belongs to a subordinate type of that genus which early became extinct. Unio hubbardi is represented by copies of Mr. Gabb's figures on Plate 5.

Mr. Gabb also described and figured $\ddagger$ another species, a strange bialate form from the Cretaceous strata of California, under the name of Unio penultimus, of which he seems to have had very imperfect specimens. Figure 1, on Plate 5, is a copy of Mr. Gabb's original figure of this form. He expressed no doubt of the correctness of his reference of that species to the genus Unio, and, notwithstanding its unusual form, there appears to be no reason to suppose that it may not belong at least to the Unionidæ. If it really is a member of this family it presents an interesting example of a subordinate type which has become extinct, while many co-ordinate types which existed contemporaneously with, or shortly after it, have come down to the present time unchanged. It is a significant and interesting fact, especially in connection with the reference of his Coalmeasure genus Naiadites to the Unionidx by Dawson, that both of the Uniones which were described by Gabb from the Cretaceous strata of the Pacific coast were found in strata associated with the coal beds of that period.

The three last-mentioned species of the Unionidæ are, with one exception, all that are at present known to have existed within the area which

* U. S. Geol. Sur. Terr., vol. ix, p. 114, pl. i, fig. 5.

†Paleontology of California, vol. ii, p. 190, pl. 30, fig. 86.

$\ddagger$ Paleontology of California, vol. i, p. 182, plate 24, fig. 164. 
is now occupied by the North American continent during the epochs that all geologists agree in referring to the Cretaceous period. It cannot be doubted, however, that many representatives of the family really lived during that period, the remains of most of which are probably forever lost, but some of which we may yet hope to discover. The exception that has been referred to is a species, the only known remains of which consist of a few fragments, too imperfect for specific characterization, which were found in the Estuary deposit at Coalville, Utah, which has already been referred to as furnishing Anomia propatoris, and is yet to be mentioned in connection with certain other species.

The cause of the apparent paucity of Unione and other non-marine molluscan remains in strata of Cretaceous age, is not, probably, that such mollusca did not then exist in very many places in greater or less abundance; but it is probably due to the fact that few of the non-marine deposits of those epochs have escaped destruction.

We come now to the consideration of a geolodical period, namely, the Laramie (which is also a remarkable period of time in the evolutional history of the Unionidæ), in which the physical conditions within the area now occupied by the North American continent were exceedingly favorable to the existence and development of non-marine mollusca. The chief of these conditions was the wide prevalence of brackish and fresh waters during the whole of that period. During the Laramie period there existed a Unione fauna that, for differentiation into a great varietv of subordinate types, is truly remarkable when we remember that it occurred at a time so remote.

It is also a remarkable fact that a large proportion of these types are precisely those which now characterize the peculiar and rich Unione fauna of the Mississippi drainage system. A part only, and apparently an unimportant part, of those subordinate types that existed during the Laramie period appear to have become extinct.

In tracing the evolutional history of any family of mollusea we should, in a general way at least, expect to find that the simplest forms were the first to appear in the order of time; and although simplicity of form of the shell is not by any means a necessary correlative of simplicity of structure in the mollusk which produced it, we nevertheless naturally inquire whether the simple shells of Anodonta did not precede in geological time the more complicated shells of Unio. This may or may not have been the case; for the difference in actual zoölogical rank between the two genera is at best measured only in part by the differences in the shells of each genus.

If, however, Professor Hall's suggestion is correct, that the two Devonian forms that have already been referred to, belong to the genus Anodonta; and if Dr. Dawson is correct in referring his Carboniferous genus Naiadites to the Unionilix, the evidence seems to be strongly in favor of the opinion that $U$ nio was actually preceded in geological time by Anodonta and other edentulous Unionidæ. 
On the other hand, if those two Deronian species are rejected as not being members of the Unionidæ, the earliest species of Anodonta that are yet known in North American strata have been obtained from the Laramie Group, although, as we have seen, diverse and characteristic forms of true Unio existed as early at least as the Jurassic period; and Margaritana appears also to have existed in the earliest epoch of the known North American Cretaceous.

One of the two species of Anodonta, which have been discovered in the Laramie Group, namely, A. propatoris White, from the Judith River beds of the Upper Missouri River region,* is represented on Plate 19. In form and general aspect it is exceedingly like certain species which are now living in North American waters. The example represented by Figs. 7 and 8 , on Plate 19, is not of fully adult size, as is shown by an accompanying figure of another, but less perfect example; but it serves to illustrate the form of the species with considerable accuracy. Fragments found associated with them show the characteristic edentulous hinge of Anodonta, one of which is represented on that plate. Indeed there can be no reasonable doubt that both Unio and Anodonta have come down from at least the close of Mesozoic time, wholly unchanged, not in generic characters only, but in those characteristics also which separate subordinate types within those genera from each other.

The other Laramie species of Anodonta, namely, A. parallela White, $\dagger$ was obtained from the valley of Crow Creek, Northern Colorado; but only fragments of the shell have yet been discovered, Fig. 5, on Plate 19, being a restoration of the form, which has been prepared by aid of those fragments. It is an unusually elongate form, but it is apparently a true Anodonta.

At the present time lacustrine waters appear to form a more congenial habitat for Anodonta than fluvatile waters do, although various species of that genus occur in both; but notwithstanding this fact, no specimens of Anodonta have been discovered in any of the great lacus. trine deposits of Tertiary àge which succeeded those of the Laramie Sea in Western North America, although several species of true Unio, as well as other fresh-water molluscan forms, are frequently found in those deposits. Notwithstanding the fact that so few of the remains of Anodonta have been discovered, it cannot be doubted that it was continuously represented by different species from at least as early a period as the Laramie down to the present time. $f$

Returning again to the genus Unio, we find it remarkably well represented in the strata of the Laramie Group and those of the immediately succeeding fresh-water Eocene Tertiary groups.

That division of the Laramie Group which is known as the Bear River

${ }^{*}$ An. Rep. U. S. Geol. Sur. Terr. for 1878, Part I, p. 62, pl. 24, fig. 2.

† An. Rep. U. S. Geol. Sur. Terr. for 1878, Part I, p. 62, pl. 24, fig. 3.

$\ddagger$ See reference to Anodonta decurtata, Conrad, under the head of spurious and doubtful species. 
beds, and which is better known in Southwestern Wyoming and the adjacent parts of Utah than elsewhere, is probably somewhat earlier in its origin than those divisions of the group which occur in other portions of that great western region.* Therefore the two species of Unio which those strata have furnished may be properly first considered.

One of these species, which is represented on Plate 6, is interesting as the type of what was regarded by Mr. Meek, who described the species under the name of Unio belliplicatus, $\dagger$ as a distinct subordinate type of Unio, to which he subsequently gave the subgeneric name

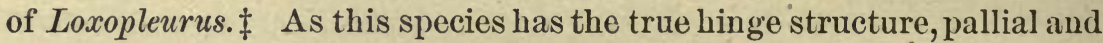
muscular markings, and ordinary external form of Unio, its assumed type characteristics consist only of its peculiar style of surface plication. It may well be questioned whether this feature is sufficient to base a subgeneric distinction upon, especially as the bent plications seem to consist essentially of a blending of small concentric folds, which are developed only near the beaks, with radiating folds, both of which are respectively found upon various other species of Unio.

The other species which has been referred to as occurring in the Bear River Laramie beds, and with which $U$. belliplicatus is usually associated, is Unio vetustus Meek, $\S$ which is figured upon Plate 7. This species has an external form somewhat similar to that of $U$. belliplicatus, but its surface is plain, except that a few more or less distinct concentric wrinkles are usually observable upon the beaks; and sometimes one or two faint radiating raised lines appear upon each side of the postero-dorsal portion. Both species have all the characteristics of true Unio well developed, and both have the front shorter than is usual among living species of that genus which have a like transversely oval outline. In the latter feature they agree with other fossil species, which are presently to be noticed.

Those strata belonging to the great Laramie group, which are somewhat extensively developed in the Upper Missiouri River region, and which have become generally known as the Judith River beds, have furnished a considerable number of species of Unio, besides one species of Anodonta, which has already been mentioned.

All the species of Unio noticed in this article, especially those of the Laramie and fresh-water Eocene groups, may be divided into several natural sections, each section representing a subordinate type of Unio, which, with one doubtful exception presently to be noticed, has repre-

\footnotetext{
* This suggestion that the Bear River beds are older than the other portions of the Laramio Group is not made with entire conficlence. It is based wholly upon the greater dissimilarity that appears between the fauna of the former than that of the latter when both are compared with living mollusea. This dissimilarity may, of course, be due to other causes than the supposed greater length of time since the existence of the Bear River fauna than has passed since that of the other portions of the Laramie group was living.

† Geol. Sur. 40th Parallel, Vol. iv, p. 165, pl. xvi, fig. 4.

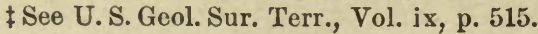

Geol. Sur. 40th Parallel, Vol. iv, p. 164, pl. XVI, fig. 5.
} 
sentatives now living in the waters of the Mississippi drainage system. These types of living Uniones, which have such well-defined-representatives among the fossil species of the Laramie Group, are among those which, being characteristic of the molluscan fauna of the Mississippi drainage system, have come to be generally known as "North American types of Unio." So unmistakable is their relationship that no reasonable doubt can be entertained that the fossil, represent the living forms ancestrally.

In only one particular, if we except the peculiar plication of $U$. belliplicatus, do any of the fossil species of Unio of Laramie or Tertiary age assume a characteristic which is either not present or not clearly recognizable in any living species among North American Uniones. This excepted characteristic consists in the extreme shortening of the shell in front of the beaks in certain of the species which have also a considerable transverse elongation and an approximately oval outline; that is, instead of having the beaks situated near, or only a little in advance of, the mid-length of the dorsal border, as they are in all the living oval and some of the shorter forms, the beaks in the case of the fossil forms in question are placed very near to the front. Short forms of Unio, of living as well as fossil species, have their beaks placed thus far forward, but attention is called to the fact that it is only in the fossil species that this peculiarity has been observed in connection with such shells as are much elongated transversely. A living species, which perhaps more nearly than any other approaches in this respect the fossil species referred to, is $U$. clavus Lamarck, which is a common shell in the Ohio River and its tributaries. But this species is, in reality, only one of the short subtriangular forms, which is a little more than usually elongate.

The Unio subspatulatus of Meek \& Hayden,* from the Judith River beds, which is illustrated on Plate 14, may be taken as an example of an elongate shell with a shortened front, such as has been referred to. In this case, however, there is an unusual narrowing of the shell posteriorly.

Associated with $U$. subspatulatus, and closely related to it, is another form which was described by the same authors under the name of Unio dance,t and which is represented on Plate 17. This species has also been somewhat doubtfully identified in the Laramie strata of Southern Wyoming, further mention of which fact is made on a following page

Two other species have been obtained from the Judith River beds, namely, Unio deweyanus Meek \& Hayden, $\ddagger$ and U. cryptorhynchus White, $\S$ both of which possess the shortened front in connection with a transversely oval outline, which features have already been discussed.

* U. S. Geol. Sur. Terr., vol. ix, p. 518, pl. 41, fig. 1.

† U. S. Geol. Sur. Terr., vol. ix, p. 517, pl. 41, fig. 3.

$\ddagger$ U. S. Geol. Sur. Terr., vol. ix, p. 519, pl. 41, fig. 2.

$\$$ An. Rep. U. S. Geol. Sur. Terr., for 1878, Part I, p. 68, pl. 24, fig. 1. 
These two species are represented on Plates 17 and 14 respectively. Some imperfect specimens of a form that seems to be specifically identical with $U$. cryptorhynchus have also been discovered in the Laramie strata at Black Buttes station. The correctness of this identification is rendered the more probable, because of similar identification of other mollnscan species in both regions, one of which has already been mentioned.

(of the Uniones that are yet known from the Judith River beds, two species remain to be noticed namely, $U$. primcevus and $U$. senectus White,* which are represented on pates 14 and 19 respectively.

These two species differ much in external form, but both are marked by small rugose plications upon the postero-dorsal portion of the surface, a feature which is not unusual among living North American species of Unio, but which is possessed by few of the known fossil species.

The aspect of these shells is so suggestive of certain features presented by some of the living forms of Unio just referred to, that it is only their fossilized condition which at first view conveys to the mind an impression of their great antiquity.

One other species, Unio priscus Meek \& Hayden, $†$ has also been obtained from the Laramie strata of the Upper Missouri River region; but this one is from the Fort Union beds which occur in a part of that great region which lies far to the eastward of that in which the Judith River beds are found. This species is of an ordinary oral outline, with a moderately short front, but without any noteworthy peculiarities. It is represented on Plate 14 by a copy of Mr. Meek's original figure.

In a single stratum of the Laramie Group at Black Buttes station, in Southern Wyoming, nearly a dozen species of Unio have been found, among which are some of the most interesting fossil forms of that genus that have ever been discovered: Some of these species have the peculiarly shortened front, together with a transversely oval form, of which mention has already been made; but in their general characteristics others of them are peculiarly like certain forms that are now living in the waters of the Mississippi drainage system.

Among these species from the Black Buttes locality is Unio cousii, White, $\ddagger$ the largest species of that genus which has ever been found in North American strata. It is represented on Plate 16. Its large size, massive test, and general aspect strongly recall certain of the large Uniones that are found living in the waters of the Wabash and other rivers of the Mississippi drainage system.

As̊sociated with $U$. couesii is another species, which is nearly as large, but of different form, namely, $U$. endlichi White, § which is represented on Plate 15.

*An. Rep. Sur. Terr. for 1878, Part I, pp. 69, 70, pl. 29, fig. 3, and pl. 28, fig. 1.

t U. S. Geol. Sur. 'Terr., vol. ix, p. 516, pl. 43, fig. 8.

¥An. Rep. U. S. Geol. Sur. Terr., for 1878, Part I, p. 64, pl. 27, fig. 1.

$\$$ An. Rep. U. S. Geol. Sur. Terr., for 1878, Part I, p. 66, pl. 26, fig. 1. 
The shells of both these large species are strong and massive, and both have strong and well developed cardinal and lateral teeth, such as are observable upon the shells of the large living river Uniones.

The other species of Unio that have been obtained from the Black Buttes locality have all been described by me under the following names respectively: Unio propheticus, U. brachyopisthus, U. proavitus, $U$. aldrichi, $U$. goniambonatus, $U$. holmesianus, and a form which I have doubtfully referred to the $U$. dana of Meek \& Hayden* has also been obtained there. These seren species are represented by appropriate figures upon Plates $13,15,16$, and 19 . They cannot fail to be especially interesting to those who are familiar with the Unione fauna of the Mississippi drainage system.

The form which is represented by figures 1 and 2, on Plate 18, has already been referred to as having been doubtfully identified with Unio dana, the type specimens of which species were obtained by Meek \& Hayden from the Judith River beds of the Upper Missouri River region. It is not improbable that further comparison will make it necessary to regard the Black Buttes form as a distinct species.

In some respects, at least, the most interesting of these fossil species of Unio is U. holmesianus White. It is especially noteworthy as indicating, in connection with its associates, the wide diversity of subordinate types that the genus Unio had attained in the Laramie period, and also as affording a fine fossil example of one of the most characteristic subordinate types of Unio that are now peculiar to North American fluvatile waters.

Unio gonionotus Whitet is illustrated on Plate 13. It was discov. ered, by Professor Powell, in the Laramie strata of Southern Utal, where alone any specimens of the species have yet been found. It is an interesting form, especially because of the strong plications which it bears, and which are similar to those that characterize various living species, and also because it possesses the excessively shortened front which has before been noticed as characterizing other fossil Uniones.

Only one other species of Unio, which is referred to the Laramie Group, remains to be noticed by name in this article; but, judging from various fragments that have been found at different localities, it is quite certain that several, perhaps many, other species exist there. Indeed, the known wide diversity of type that the genus Unio had attained during the Laramie period seems necessarily to imply that a greater num. ber of specific forms then existed than have yet been discovered.

The species last referred to, and which is illustrated on Plate 18, I have described under the name of Unio mendax. $\ddagger$ Specimens of it

* For original descriptions and figures of these seven forms see An. Rep. U. S. Geol. Sur. Terr. for 1878, Part I, pp. 62-68, pl. 22, 26, 27, and 29.

† An. Rep. U. S. Geol. Sur. Terr. for 1878, Part I, p. 71, pl. 26, fig. 2.

$\ddagger$ Bull. U. S. Geol. Sur. Terr., vol. iii, p. 605 .

$28 \mathrm{G}$ 
have been collected, by Professor Powell, from certain strata in the Cañon of Desolation, and others, by one of the parties under Lientenant Wheeler, from the coal-bearing strata at Wales, Utah, all of which probably belong to the upper portion of the Laramie Group. The specimens obtained at Wales were erroneously referred by me to $U$. vetustus Meek,* which species $U$. mendax resembles in certain particulars.

In the Eocene fresh-water deposits, which immediately succeeded the Laramie, several species of Unio have been found; and it is a note. worthy fact that while there was great diversity of form and considerable diversity of surface ornamentation among the species of Unio that existed in the Laramie period, all the species of that genus which have yet been found in the purely fresh-water Eocene deposits have a transversely oval form and plain surface; that is, there are among the latter no short forms, like several of those of the Laramie Group and many among living species, and none of them have the surface marked by plications, rugæ, or pustules; nor are they marked in any other manner except by the ordinary concentric lines of growth. Most of these oval shells also have the beaks placed at least a moderate distance from the front, as is usual in the case of living species of oval form; but one of them at least possesses a shortened front, like that of several of the Uniones of the Laramie Group which have already been noticed.

The species referred to is Unio clinopisthus White, which is described and figured for the first time, as follows: Unio clinopisthus (sp. nov.), Plate 28, Figs. 1 and 2. Shell transversely elongate, short in front of the beaks, elongate and narrowing behind them to the posterior end; basal margin having a gentle sinuosity, there being a slight emargination just behind the midlength; front margin regularly rounded; dorsal margin proper rather short; postero-dorsal margin forming a long, convex, downward slope from the dorsal to the postero-basal margin, which latter margin is narrowly rounded; beaks depressed and placed near the front of the shell. A somewhat prominent, but not sharply defined, umbonal ridge extends from the beak of each valve to the postero-basal margin, giving a flattened space at the postero-dorsal portion of each valve. Surface marked only by concentric lines of growth.

Length, 63 millimeters; height, 30 millimeters; thickness, both valves together, 23 millimeters.

This species was collected by Dr. Hayden from the fresh-water Eocene strata, near Washakie Station, in Southern Wyoming.

Another species, quite a large one, to which I hare given the name of Unio Meekii, changing it from U. leai Meek, which name was preoccupied, was obtained by Dr. Hayden from the Bridger Group of Southern Wyoming. This form is yet known only by fragments and natural casts of the interior; but it is known to have been a large, plain shell

\footnotetext{
"Expl. and Sur. West of the 100th Merid., vol. iv, p. 206, pl. XXII, fig. 12, a, b, c, and $\mathrm{d}$.
} 
of transversely oval outline, and having the anterior portion rather short in front of the beaks.*

The remaining three species of Unio yet to be noticed are all of the simple elongate, or transversely oval form, so common among living representatives of the genus.

The first is $U$. shoshonensis White, $\nmid$ which is figured on Plate 28. Specimens of it have been found at various localities in Southern Wyoming and the adjacent parts of Colorado and Utah, in the Wahsatch Group of fresh-water Eocene strata there.

The next is $U$. washakiensis Meek, $\ddagger$ which is figured on Plate 28, and which has a similar geographical range and geological position. It seems also to range upward into the Bridger Group.

The third and last is $U$. haydeni Meek, $\S$ which is represented on Plate 28. This species closely resembles $U$. shoshonensis in external form, but it is a thinner and more delicate shell, with a more slender hinge. It also comes from a different group of strata. It is not improbable that $U$.haydeni is identical with the species that was described by Hall under the name of Mya tellinoides.\| For purposes of comparison Professor Hall's principal figure of that form is copied on Plate 28.

Although there are fresh-water deposits of considerable extent in Western North America of later date than the Eocene Tertiary epoch which have furnished numerous vertebrate, and a few molluscan remains, no Uniones, and only a few other bivalve species, which are referred to Sphorium, have been found in any of them. In a few instances, some Uniones have been discovered in certain Post-Tertiary deposits, but as they have all been referred to living species, they do not come within the scope of this article. I

\section{CYRENIDE.}

The geological history of the Cyrenidæ of North America, as it is at present known, begins with the earliest epoch of the Cretaceous; but it was no doubt actually introduced much earlier.

The family has apparently never formed a very prominent feature of any molluscan fauna, either marine or non-marine, in any of the geological periods, except that of the Laramie, since its introduction. In this period there was so extraordinary a development of the genus Cor-

* This species is described, and a cast of one valve figured in An. Rep. U. S. Geol. Sur. Terr., for 1878, Part I, p. 43, pl. 19, fig. 1. Owing to the imperfection of all the specimens of this species that have yet been discovered, no figure of it is given in this article.

t An. Rep. U. S. Geol. Sur. Terr., for 1878, Part I, p. 41, pl. 19, fig. 2.

†An. Rep. U. S. Geol. Sur. Terr., for 1878, Part I, p. 42, pl. 19, fig. 3.

s Simpson's Report Great Basin of Utah, p. 364, pl. 5, fig. 11.

\| Fremont's Rep. Oregon and N. California, p. 307, pl. iii, figs. 1 and 2.

I For an interesting discovery of this kind, by Prof. John Collett, in Indiana, see 7th An. Report Geol. Sur. Indiana, p. 246. See also, on a following page, remarks on spurious and donbtful species. 
bicula as to give an impression to the casual observer that the family then reached a culmintion, but it was in reality a culmination of the genus Corbicula only.

In the Cretaceous strata of the western part of the continent several species belonging to the Cyrenidæ have been discovered, all of which are referred to the genus Cyrena as distinguished from Corbicula.* Only two of these species, however, are regarded as coming within the scope of this article, because all the others are found to be associated with such forms as are regarded as indicating a marine habitat, while those two species are associated with non-marine forms. Although in the Cre: tacious period the genus Cyrena was established with all its distinctive characteristics, as they are at present known, and was represented by sereral known species in the southern portion of North America, with one or two exceptions the genus has not been recognized in strata of any geological period since the Cretaceous.

And again, although the genus Corbicula formed so conspicuous a feature of the fauna of the Laramie period, it is at present not known to occur in any North Americau strata of either earlier or later date than that period; if we except the $C$. truncata of Prime, which is understood to be of doubtful authenticity. These facts are significant as regards the genetic history of the family, and show, among other things, that our knowledge of that history is far from complete.

The earlier of the two non-marine fossil species of Cyrena that havo just been referred to, is $C$. dakotensis Meek \& Hayden, $\dagger$ which has already been mentioned on a previous page as an associate of Margaritana nebrascensis in strata of the Dakota Group in Southeastern Dakota. It is represented on Plate 4 by copies of Mr. Meek's original figures.

The other species is Cyrena carletoni Meek, $\ddagger$ which is represented on Plate 5, and which was discovered by Mr. Meek in the Cretaceous estuary deposit at Coalville, Utah, which has already been mentioned in connection with remarks upon Anomia propatoris. The only examples of this species that have been discovered are small and delicate, and it is probable that they are all young shells.

Although the family Cyrenidæ has evidently become well established in the estuary and marine waters of the Cretaceous period, at least by its typical genus Cyrena, it is in the strata of the Laramie Group, as before stated, that we find evidence of its greatest development, especially as regards the genus Corbicula. Among the fossil forms of that genus which the Laramie Group has furnished, three sections or subgenera are recognized, two of which have become extinct.

Beginning with the Bear River beds of the Laramie Group, which are perhaps somewhat earlier than the other known portions of the group,

"For remarks on these genera, by Mr. Meek, see U. S. Geol. Sur. Terr., vol. ix, p. 157.

†U. S. Geol. Sur. Terr., vol. ix, p. 159, pl. I, fig. 1.

$\ddagger$ An. Rep. U. S. Geol. Sur. Terr. for 1878, Part I, p. 20, pl. 12, flg. 16. 
we find in Southwestern Wyoming, and the adjacent parts of Utah, one species of Corbicula which is interesting as being the type of a section of that genus for which Mr. Meek proposed the subgeneric name of $V e$ loritina.* This species, which he described under the name of Corbicula (Veloritina) durkeei, $\uparrow$ is represented on Plate 8.

Two species of Corbicula were described by Meek \& Hayden from the Judith River beds of the Upper Missouri River region, under the names respectively of $C$. cytheriformis and $C$. occidentalis, $\$$ which are represented on Plates 22 and 23 respectively. The first-named species is referred to the typical section of the genus; but the latter approaches -in form the type of the subgenus Veloritina. Both these species have also been obtained from Laramie strata of Bitter Creek Valley in Southern Wyoming.

The form which was described by Meek from that region, under the name of $C$. bannisteri, is regarded as identical with $C$. occidentalis. $\oint$ This form is represented on Plate 17.

Two other Laramie species of Corbicula were described by Meek \& Hayden, from the Upper Missouri River region, both of which are, however, from the Fort Union beds. They are respectively $C$. nebrascensis and C. subelliptica, both of which are represented on Plate 20. The latter has been recognized in the Laramie strata of Colorado east of the Rocky Mountains. It was referred by Mr. Meek to his subgenus Leptesthes.\|

It seems not improbable that $C$. nebrascensis is only a young example of $C$. cytheriformis, but as that question is not yet settled, the former is here treated as a distinct species as well as the latter.

The Laramie strata east of the Rocky Mountains in Colorado, which were by Dr. Hayden designated as the Lignitic Group, have been found in several localities to be especially rich in Corbicula. A part of these species are referable to the typical section of the genus and a part to the subgenus Leptesthes. To the latter subgenus belong $C$. subelliptica Meek \& Hayden, C. macropistia White, C. planumbona Meek, and $C$. cardiniaformis White; $\uparrow$ all of which are figured on Plates 21 and 22.

Since the last-named form was published numerous other examples have been discovered which make it probable that it should be regarded as a variety of $O$. fracta Meek.

Other published species found in the valley of South Platte, and its tributaries in Colorado, are C. cleburni and C. obesa White,** which are figured on Plates 20 and 23 respectively.

"See U. S. Geol. Sur. Terr., Vol. ix, p. 161, for a diagnosis of this subgenus.

†U. S. Geol. Sur. 40th parallel, vol. iv, p. 167, pl, lvi, fig. 6.

‡U.S. Geol. Terr., vol. ix, pp.520, 521, pl. 40, figs. 5 aud 6. Also, An. Rep. U.S. Geol. Sur. Terr. for 1878, Part I, pp. 74, 75, pl. 21.

ó See An. Rep. U. S. Geol. Sur. Ter. for 1878, Part I, p. 75.

\| For diagnosis of this subgenus, see U. S. Geol. Sur. Terr., vol. ix., p. 161.

Tा These species are described and figured in the An. Rep. U. S. Geol. Sur. Terr. for 1878, Part I. References are also given there to original descriptions.

" "See An. Rep. U. S. Geol. Sur. Terr. for 1878, part I, pp. 73, 73, p1. 23. 
In addition to the six species last-mentioned, the three which are doscribed in the following paragraphs for the first time, have been discovered in the Laramie strata of South Platte Valey, Colorado, since the former were published.

Corbicula berthoudi (sp. nor.), Plate 21, figs. 1, 2, and 3.-Shell very large, subtrigonal in marginal outline, moderately gibbous; front concave immediately in front of the beaks; front margin regularly rounded; basal margin broadly rounded; postero-basal margin abruptly rounded up to the postero-dorsal margin, which latter margin slopes obliquely downward with a gentle convexity from between the beaks; hinge strong; all the teeth well developed, the lateral ones especially being long and large and crenulated upon their edges, as is usual with all the known species of Corbicula of the Laramie Group; muscular and pallial impressions having the usual characteristics; surface marked with the usual concentric lines.

Length of one of the largest examples in the collections, 62 millimeters; height from base to umbo, 54 millimeters; thickness, both valves together, 44 millimeters.

This fine large species, the largest yet known in North America, has been found only in the Laramie strata east of the Rocky Mountains in Colorado. It is named in honor of Capt. E. L. Berthond, the first discoverer of the rich shell deposits of the Laramie Group in that region.

Corbicula augheyi (sp. nov.), Plate 21, figs. 4, 5, and 6.-Shell moderately large, sub-tetrahedral in marginal outline, postero-dorsal region not flattened, as in $C$. berthoudi; umbones full, rounded, considerably elevated above the hinge-line, front regularly rounded; basal margin broadly convex; posterior end truncated, the direction of the truncated margin usually a little backward of a line drawn perpendicularly with the base of the shell; postero-dorsal margin a little convex; hinge well developed; muscular and pallial markings of the usual character; surface marked by the usual concentric lines of growth, and usually by very faint umbonal ridges extending from the umbo to the posterodorsal and postero-basal margins respectively upon each valve.

Length of an adult example, 46 millimeters; height from base to umbones, 38 millimeters; thickness, both valves together, 30 millimeters.

This species has yet been found only in the valley of South Platte River, in Northern Colorado, east of the Rocky Mountains. It is named in houor of Prof. Samuel Aughey, of Nebraska State University, who assisted me in the collection of the type specimens.

Corbicula umbonella* Meek; Plate 21, Figs. 7, 8, 9, and 10.-Shell resembling $C$. obesa White, in most respects, but it is proportionally longer, the umbones are fuller and more elevated, and upon the posterior portion there are upon each valre two or three indistinct radiating rugæ. Upon other parts the surface is more than usually smooth.

\footnotetext{
"Seo Bull. U. S. Geol. Sur. Terr., Sec. Ser., No. 1, p. 44, where this species is named but not described.
} 
Length, 39 millimeters; height from base to umbones, 34 millimeters; thickness, both valves together, 26 millimeters.

The large series of examples of all the déscribed species of Corbicula. that have been obtained from the Laramie strata east of the liocky Mountains in Colorado give unmistakable indications of genetic relationship between them. It has already been stated that $C$. cardiniocformis is perhaps only a variety of $C$. fracta; and it may be remarked that $C$. obesa, C. umbonella, and $C$. augheyi hold similar relations to each other. It is not unlikely that when all the Corbiculæ of the Laramie Group come to be fully studied, some of the species heretofore described must be abandoned; but in an article like this, it is thought best to make mention of, and to figure, all the forms that have been published by any author, as he has published them.

The species which Mr. Meek adopted as the type of his subgenus Leptesthes, namely, $O .(L$. $)$ fracta* Meek, has been found in considerable abundance at Black Buttes station, in Southern Wyoming, and sparingly also at other localities on both sides of the Rocky Mountains. It is figured on Plate 20.

This is the largest species of the subgenus Leptesthes yet known, and with the exception of $C$. berthoudi, herein described, the largest species of Corbicula that has ever been discovered in North American strata. The figures that are here giren show it to be a very variable species as regards external form. Fig. 1, on Plate 20, is a copy of Mr. Meek's drawing from his type specimen. The partial truncation of the posterior border is a slight deformity of that specimen, and is not common to the species. The dimensions of that figure are also somewhat less than the average for adult shells. Figs. 4 and 5, on Plate 20, represent two views of a young example of ordinary form, but some examples of this species are more elongate transversely.

No examples of the genus Sphorium have been found in any North American strata of older date than the Laramie Group, and none have been published from that group except the four species which were obtained by Meek \& Hayden from the Upper Missouri River region, and described by them respectively under the names Sphciorium planum, S. recticardinale, S. formosum, and S. subellipticum.t These four species are all represented on Plate 17 by copies of Mr. Meek's original figures. The two first-named species are from the Judith River beds, and the other two from the Fort Union beds. Some fragments of a species of Spharium, which is perhaps different from either of the four species above referred to, have been discorered in the coal-bearing beds at Eranston, Wyoming, which beds seem to belong to the upper part of the Laramie Group.

A few imperfect examples, too imperfect for specific characterization, but evidently belonging to one or more species of the genus Spharium,

" See U. S, Geol. Sur. Terr., vol. ix, p. 161.

† See U. S. Geol. Sur. Terr., vol. ix, pp. 526, 527, pl. 43. 
have been found in the Eocene fresh-water deposits of Sonthern Wyoming, which are, like those of the Laramie Group, so similar to certain living species as to call for no distinguishing remarks.

We yet know nothing of the existence of Sphorium in North America between the close of the Eocene epoch and the Post-Tertiary except the two species which were respectively described by Meek under the names Sphacrium rugosum and S. idahoense, both of which are represented on Plate 32 by copies of his original figures. The types of these two species were obtained from the fresh-water deposit of the Kawsoh Mountains of Northern Nevada, which is regarded as of Miocene age by parties connected with the United States Geological Survey of the 40th parallel.* We do not jet know even so much as this of the history of the Unionidr between the close of the Eocene epoch and the beginning of the Post-Tertiary; $\uparrow$ yet we cannot doubt that both Unio and Sphorium flourished together somewhere during all that time.

\section{PISIDIIDE.}

Of the genus Pisidium, only one fossil species, namely $P$. saginatum White, has yet been discovered. $\neq$ Its form is represented by figures 14 and 15 , on Plate 20, and it is by its outward features alone that it is referred to Pisidium, the interior markings of the shell having never been ascertained. It was obtained from the series of coal-bearing strata near Evanston, Wyoming, which are at present understood as belonging to the upper part of the Laramie Group.

While it seems to be unquestionable that the living Unionidx of the Mississippi drainage system are generically descended from those species which, as we have seen, existed during the Laramie period, and from their associates which yet remain to be discovered, no descendants of the Cyrenidre which then existed seem to have survired the close of the Laramie period, except those of the genera Sphcerium and Pisidium. In fact, all three of the sections of the genus Corbicula, which have been mentioned as having lived during the Laramie period, seem to have required the same conditions of habitat that the contemporaneous Ostrea and Anomia did. When, therefore, at the close of the Laramie period, the waters of the interior region of North America became entirely fresh, all the forms of Corbicula which had flourished throughout that great region ceased to exist; while Sphcrium and Pisidium, whose habitat is in fresh water only, survived to the present time, doubtless in company with representatives of the Unionidæ, and with many freshwater gasteropods. This opinion of course implies not only the belief that while the living Uniones of the Mississippi drainage system are, either wholly or in part, directly descended from those whose remains

\footnotetext{
" U. S. Geol. Sur. 40th parallel, vol. iv, pp. 182, 183, pl. xvi, figs. 1 and 2.

†That is, if we omit all those which are mentioned on following pages under the head of spurious and doubtful species.

.$\ddagger$ Powell's Report Geology of the Uinta Mountains, p. 128.
} 
we find in the strata of the Laramie Group, but also the belief that the brackish water Cyrenidæ which existed contemporaneusly with them in the Laramie period are not thus ancestrally related to the living species of Cyrena and Corbicula of North America, but that the latter have come down by some other liness of descent which are not yet known.

\section{CORBULIDAE.}

The genus Corbula is represented by several species in the Crotaceous strata of North America; but all the species that are yet known from strata of that period are found associated with marine forms; and, as they no doubt lived in marine waters, they do not fall within the scope of this article. Three or four species are known to have lived during the Laramie period, the faunal associates of which indicate a brackish water habitat; and as no other fossil species of this genus have been discovered under such circumstances as to make it probable that they lived in other than marine waters, we shall have only those Laramie forms to discuss at the present time.

Nine species of Corbula have been described and named by different authors, from strata which have been studied at different localities, all of which strata are now referred to the Laramie Group; but at present I am disposed to regard less than half of them as distinct species, the remainder being regarded as at least no more than varieties of those species, respectively.

Mr. Meek regarded all the Laramie species of Corbula as not belong. ing to the typical section of the genus; and he referred one of them to the proposed subgenus Anisorhynchus of Conrad, and the others to Pachyodon Gabb. In this article, however, I shall treat all the species herein discussed as true Corbula, without expressing an opinion as to the sections of the genus proposed by Conrad and Gabb; but it is proper to call attention to the fact that the first two mentioned of the following species present a facies or type which is quite different from that of any living North American species of Corbula. Indeed, we may regard these Laramie forms as representing extinct lines of descent, for it is practically certain that the line of descent of none of the living species of Corbula has eome down through any of those of the Laramie period as represented by the strata which we now know as the Laramie Group.

The reasons for this opinion are expressed in the remarks that have been made in relation to the Cyrenidse of the Laramie Group, and the subject is further discussed in the remarks which close this article.

Since the Bear River beds are hypothetically regarded as the earlier portion of the Laramie Group, the first of the species of Corbula to be mentioned is C.pyriformis Meek,* which has been found only in thosé beds, and their equivalents in Southwestern Wyoming and the adjacent

"See Simpson's Rep. Great Basin Utah, p. 361, pl. v, figs. 9 and 10. Also U. S. Geol. Sur. 40th Parallel, vol. iv, p. 170, pl, xvii, fig. 2. 
parts of Utab. It is represented on Plate 8. Mr. Meek described another form in connection with this under the name of $C$. englemanni, but the numerous examples that have been collected from those strata show such a degree of variation as to make it very doubtful whether the difference between the two forms is anything more than individual variation. $C$. englemanni is therefore regarded as a synonym of $C$. pyriformis.

An interesting species, which occurs in the valleys of Bitter Creek, Southern Wyoming, and Yampa River, Northwestern Colorado, was described by Mr. Meek under the name of Corbula undifera, which is illustrated on Plate 18. A variety of this species, which also occurs in the valley of Bitter Creek, but at a higher horizon in the Laramie Group by several hundred feet, was described by me under the name of $C$. subundifera.* Although the latter is now regarded as only a variety of the former, yet the variation is quite constant and readily recognizable, as may be seen by comparing the figures of the variety with those of the typical form on Plate 18.

Two species were described by Meek \& Hayden from the Judith River beds of the Upper Missouri River region, under the names respectively of Corbula subtrigonalis and $C$. perundata, both of which I regard as belonging to one and the same species. Furthermore, the two species which were described by Meek from the Laramie strata of the valley of Bitter Creek, Southern Wyoming, under the names respectively of $C$. tropidophora and C.crassatelliformis, I regard as also belonging to that species, making three synonyms of $C$. subtrigonalis. Figures of these forms may be seen on Plate 19.

One other published form of Corbula only remains to be noticed in this article, namely, C. mactriformis, $\ddagger$ which was described by Meek \& Hayden from the Fort Union beds of the Upper Missouri River region, and which has hitherto been found nowhere else. It is represented on Plate 18.

The non-marine bivalre mollusca that have been noticed on the preceding pages comprise only six families, while, as we shall see, their associated gasteropod families were more than double that number. This numerical proportion of the families pertaining to the Conchifera and Gasteropoda, respectively, may be taken as about the same as that which obtains in those two classes among living non-marine mollusca. Indeed, the familieswhich have been recognized among these fossil forms are no other than those under which wo group their living representatives.

\footnotetext{
"For descriptions and figures of both these forms see An. Rep. U. S..Geol. Sur. Terr. for 1878, Part I, pp. 80, 81, pl. 29.

fFor descriptions and figures of these forms and remarks upon them see U. S. Geol. Sur. Terr., vol. ix, pp. 529, 530, pl. 40; An. Rep. U. S. Geol. Sur. Terr. for 1870, p. 315 ; $i b$. for 1872 , p. 514 ; $i b$. for 1878 , Part I, pp. 80, 81, pl. 25.

$\ddagger$ U. S. Geol. Sur. Terr., vol. ix, p. 528, pl. 42, fig. 7 .
} 
Moreover, the majority of the genera, and many of the subordinate divisions of those genera, possess no recognizable variation from those under which we are accustomed to range the living species. We have, however, seen that a small number of those subordinate types among the Conchifers have become extinct; and we shall see that still more of them among the Gasteropoda, together with a few of that class that we regard as full genera, have also become extinct; but yet the fact remains that these ancient non-marine mollusca, as a whole, are wonderfully like their living representatives.*

\section{GASTEROPODA.}

Although, in zoölogical rank, the gasteropoda are so much in advance of the Conchifera, the various families of the former seem to have been developed as early in geological time as those of the latter; and so far as we are now acquainted with the history of the fossil non-marine mollusca of North America, it appears that highly organized land pulmonate gasteropods were introduced quite as early as any of the. Conchifers. Indeed, from present indications, we are led to believe that the relations of the different classes of non-marine mollusca to each other were much the same in all geological epochs as they are to-day.

\section{AURICULIDE.}

Three or four species of gasteropods have been discovered in the Cretaceous estuary deposits, and those of Bear River, Laramie series, which are regarded as belonging to the family Auriculidæ; and these are the only members of that family which have been discovered in North American strata, and the only ones that come within the scope of this article.

One of these species was discovered by Mr. Meek in the Cretaceous estuary deposit at Coalville, Utah, $\uparrow$ which has already been mentioned

* There have been found in the Laramie Group two Conchifers and one Gasteropod, which, so far as is now known, have living allies only in marine waters, and they are therefore not enumerated in this article, although they seem to have survived in the brackish water Laramie Sea from the time when it was an open sea of marine saltness. They are respectively Nuculana inclara, Axincea holmesiana and Odontobasis buccinoides White. With these exceptions, all the known molluscan species of the Laramie Group are such as we should naturally refer to some non-marine habitat. It is not at all improbable that these species of genera which are usually characteristic of open-sea waters survived the land-locking of the Laramie Sea, and did not yield up their existence nntil the complete freshening of the waters took place, when their associates Corbicula, Corbula, Neritina, \&c., also ceased to exist. The species which was described by me as Odontobasis? formosa probably belongs to some genus of the Ceriphasiidæ. For remarks upon the species referred to in this note, with descriptions and figures, see An. Rep. U.S. Geol. Sur. Terr. for 1878, Part I, pp. 59, 60, 102, and 103; plates 20, 25, and 28.

tAn. Rep. U. S. Geol. Sur. Terr. for 1878, Part I, p. 23, pl. 12, fig. 11. 
in conuection with Anomia propatoris and Cyrena carletoni. It was originally described by Meek under the name of Melampus? antiquus, but it is quite certain that it does not strictly belong to that genus. It is illustrated by several figures on Plate 5 .

An imperfect example of a similar and apparently congeneric form, which is represented by Fig. 17 on Plate 5 was found in the same neighborhood among the remains of marine Cretaceuns mollusca, as was also an imperfect example of Physa; both of which specimens were no doubt drifted from the then adjacent shore, and sunk amoug the shells of marine mollusks that then lived there.*

In the Bear River Laramie beds in Southwestern Wyoming there have been found two species closely related to the two that are referred to Melampus?, which, from their characteristics as well as their brackishwater fannal associations are referred to the Auriculidæ. They have considerable resemblance to Melampus? antiquus, and are possibly congeneric with it; but Mr. Meek proposed for them the generic name of Rhytophorus. $\dagger$

The first of these two species was discovered by Mr. Meek, and described by him under the name of Rhytophorus priscus ; $\ddagger$ and the second was described by myself under the name of $R$. meekii. B Both these forms are illustrated by figures on Plate 8.

These three or four species constitute the only representatives of the Auriculidæ that have yet been obtained from North American non-marine strata, and they are so remotely allied with living representatives of that family that we cannot regard them as holding such ancestral relation to any of the living North American Auriculidæ as the fossil Unionidæ and some other families herein discussed, evidently hold to the living representatives of those families respectively. Indeed, for reasons already stated, it is practically certain that the lines of descent from such of the mollusca of the Laramie period as required a saline habitat were necessarily broken at the close of that period, when the waters of that sea became wholly fresh and greatly reduced in extent.

LIMNEID E.

The earliest North American strata in which remains of the Limnæidæ have been discovered are those of the Laramie Group; if we except the Jurassic form, which was described by Meek \& Hayden under the name of Planorbis veternus, and which is presently to be further mentioned. In the Laramie Group, however, we find the family represented by all the principal genera that are known among the living Limnæidæ, as well as the greater part of the subordinate sections of the

" See An. Rep. U. S. Geol. Sur. Terr. for 1878., Part I, p. 25. Ib. for 1877, p. 307.

† For diagnosis of this genus see U. S. Geol. Sur. 40th Parallel, vol.iv, p. 175.

$\ddagger$ U. S. Geol. Sur. 40th Parallel, vol.iv. p. 175, pl. xvii, fig. 6. Also Simpson's Rep. Great Basin, Utah, p. 364, pl. v, fig. 4.

f See An. Rep. U. S. Geol. Sur. Terr. for 1878, Part I, p. 82, pl. 30, fig. 8. 
genera which constitute that family. These facts necessarily point back to a period much more remote than the Laramie, for the origin of the family, and although we lack the positive evidence of the fact, we cannot doubt that it not only had its origin as early as the beginning of Mesozoic time, but that it had then become well established.

The earliest known species belonging to the genus Limnoea is $L$. nitidula Meek,* which is found in the Bear River Laramie strata of Southwestern Wyoming. It is represented on Plate 6 . It is referred to the subgenus Limnophysa Fitzinger. Among its faunal associates is a minute form, which I. have described under the name of Acella haldemani, $\dagger$ which is represented by enlarged figures on Plate 6 .

Associated with these is also a small Planorbis, belonging to the subgenus Gyraulus Agassiz.

It is a fact which doubtless indicates the imperfection of our present knowledge that, while those two widely differentiated members of the Limnæidæ are found in what are regarded as probably the earlier strata of the Laramie Group, the only other species which is referable to the subfamily Limnæinæ that has been found in any part of that group is a form, which was deseribed by Meek \& Hayden, from the Fort Union beds, under the name of Limnca tenuicostata. $\ddagger$ Mr. Meek proposed for this form the subgeneric name of Pleurolimncea, but it might probably be referred to Acella with equal propriety. It is represented by a copy of Mr. Meek's figure on Plate 23. Although a greater number of the Planorbinæ than of the Limnæinæ have been discovered in the Laramie Group, the apparent absence of the latter from most of the fossiliferous strata of that group, even those which contain other palustral pulnonates, such as Physa and Bulinus, is unexpected, and, as before intimated, it is probably not because they did not exist, but becanse they have not been discovered.

Mr. Meek described a species under the name of Limncea (Limnophysa?) compactilis, $\S$ from Separation Station in Southern Wyoming, which was obtained from strata that he regarded as Tertiary, but which doubtless belongs to the Laramie Group. It probably belongs to the genus Thaumastus, and not to Limnoca. It is represented on Plate 26 by figures of Mr. Meek's type specimen.

Mr. Meek described two species of Limncea, which he stated were discovered in the Bridger Group of Eocene fresh-water strata in Southern Wyoming. He named them respectively $L$. vetusta and $L$. similis.\| Both these forms are represented by copies of Mr. Meek's figures on Plate 29.

\section{From the Green River Eocene Group of Southern Wyoming I have}

* U. S. Geol. Sur. 40th Parallel, vol. iv, p. 181, pl. xvii, fig. 5.

†An. Rep. U. S. Geol. Sur. Terr. for 1878, Part I, p. 84, pl. 30, fig. 9.

$\ddagger$ See U. S. Geol. Sur. Terr., vol. ix, p. 534, pl. 44, fig. 13.

$\$$ An. Rep. U. S. Geol. Sur. Terr. for 1872, p. 517.

\| U. S. Geol. Sur. 40th Parallel, vol. iv, p. 191, pl. xvii, figs. 3 and 4. Also, Simpson's Rep. Great Basin, Utal, p. 367, pl. v, figs. 2 and 3. 
described a species under the name of $L$. minuscula, ${ }^{*}$ which evidently belongs to the subgenus Leptolimnaca Swainson. It is represented on Plate 29.

The species that have just been mentioned are all that are known to have existed in North America up to the close of the Eocene epoch, which pertain to the comprehensive genus Limncea. The fresh-water strata, which are known as the White River Group, and are referred to the Miocene Tertiary, are the only strata of that epoch which are at present known to contain any remains of Limncea. In that group two species of Limncea have been discovered, namely, L. meekii Evans \& Shumard, and $L$. shumardi Meek. $\dagger$ Both of these species belong, apparently, to the typical section of the genus, and both are represented by copies of Mr. Meek's original figures on Plate 32.

If the non-marine molluscan fauna, of the epoch of which the White River Group is a partial representative, were better known, it may bo regarded as certain that we should find in it many representatives of living types; but so far as that fauna is at present known, it is a very meager one, and confined to the pulmonate gasteropods. The apparent entire absence of gill-bearing mollusks in those portions of that formation which have been examined, may, perhaps, have been due to a solution in the waters in which they were deposited, of certain salts or other substances which made them uncongenial for molluscan life. If this were really the case, the presence there of the remains of pulmonate gasteropods might be accounted for on the supposition that they were drifted into those waters by tributary streams in or upon the banks of which they lived.

The only other species of Limncaa to be mentioned in this article is the one which was described by Mr. Meek under the name of L. kingii, and for which he proposed the subgeneric name of Polyrhitis. $\neq$ It was obtained from certain strata in Cache Valley, Utah, which are not of earlier date than the Miocene, and which are probably of Pliocene age. Copies of Meek's original figures of this form are given on Plate 32. It is an interesting form because of the fact that it is the only known representative of the only extinct subordinate type of Limnoca that is yet known, and because it comes down to a later date than most of the other extinct types of mollusca, of which mention is made in this article.

Of the other genera of the family Limnæidæ, Planorbis and Carinifex, remain to be considered. The earliest species of Planorbis yet discovered in North American strata is $P$. veturnus Meek \& Hayden, $\S$ which those

\footnotetext{
${ }^{*}$ Proc. U. S. Nat. Museum, vol. iii, p. 160.

t For descriptions and figures of theso two species seo U. S. Geol. Sur. Terr., vol. iv, pp. 598 and 599, pl. 45 , figs. 5 and 6.

$\$$ For deseription and figures of this species see U. S. Geol. Sur. Terr., 40th parallel, vol. iv, p. 192; and for Meek's diagnosis of the subgenus see U. S. Geol. Sur. Terr., vol. ix, p. 532.

$\$$ Paleontology of the Upper Missouri, p. 107, pl. iv, fig. 1.
} 
authors reported as coming from Jurassic strata in the vicinity of the Black Hills, where they found it associated with Unio nucalis and other species, which have already been referred to. It is represented on Plate 3.

It cannot be doubted that various species of Planorbis existed during the whole of the Cretaceous period, but no evidence of the fact has yet been obtained. In the Bear River Laramie beds, however, a small, undescribed species is known, as already mentioned, which belongs to the subgenus Gyraulus.

In the Laramie period the genus Planorbis is believed to have flourished; not because many examples have been found in those strata, but because the examples which have been discovered indicate that the different species which they represent reached a wide range of differentiation. Meek \& Hayden described Planorbis convolutus* from Laramie strata, in the Upper Missouri River region, which they regarded as of the age of the Judith River beds. This species seems to be referable to, or not widely different from, the typical section of the genus as it is known among living forms. It is represented on Plate 27.

The subgenus Bathyomphalus Agassiz, although not known to be now living in North America, is represented by three species in the Laramie Group; but it has not been recognized in any strata that are referred to a later date. One of these species was obtained from the Judith River beds, and was described by Meek \& Hayden under the name of Planorbis (Bathyomphalus) amplexus; $t$ and the other, by the same authors, from the Fort Union beds, under the name of $P .(B)$ planoconvexus.t.

Still another species, obtained from the Laramie strata of Southern Utah by Professor Powell, was described by myself under the name of Planorbis (Bathyomphalus) kanabensis.ई All three of these forms are represented on Plate 27.

Besides the species of Gyraulus that has already been mentioned as existing in the Bear River Laramie beds, another was obtained by one of the parties under the direction of Lieutenant Wheeler, from strata that belong to either the upper part of the Laramie Group, or the lower portion of the Eocene. This species I have described under the name of Planorbis (Gyraulus) militaris.\| It is illustrated on Plate 28.

A fine large species of Planorbis was described by Mr. Meek from the Bridger Group of Southern Wyoming, under the name of $P$. utahensis, and also a variety of the same under the name of P. spectabilis. T Both these forms are illustrated on Plate 29.

*U. S. Geol. Sur. Terr., vol. ix, p. 536, pl. 43, fig. 11.

† U. S. Geol. Sur. Terr., vol. ix, p. 539, pl. 42, fig. 16.

$\ddagger$ U. S. Geol. Sur. Terr., vol. ix, p. 538, pl. 44, fig. 9.

$\$$ Powell's Rep, Geology of the Unita Mountains, p. 119.

\| Proceedings U. S. National Museum, vol, iii, p. 159.

If For Meek's descriptions and figures of these two forms see U. S. Geol. Sur., 40th Parallel, pp. 189, 190, pl. xvii, figs. 13 and 14 ; Simpson's Rep. Great Basin, Utab, pp. 266, 267, pl. v, figs. 6 and 7. Also see Expl. and Sur. West of 100th Merid., vol. iv, p. 209, pl. $x x i$, fig. 8, for description and figures by White. 
This species is similar in outward form to those which have been grouped under the subgeneric name of Gyraulus; but in size it is very much greater than any of the species which have been referred to that subgenus.

A species somewhat similar to the last, but smaller, more nearly discoid in form, and having much more slender rolutions, was obtained by my. self from the Green River Group of Southern Wyoming, and described - under the name of Planorbis cirratus.* It is illustraterl on Plate 29. From the same region and from the same formation I also obtained Planorbis aqualis White, $\uparrow$ which is illustrated on Plate 29 . It seems to possess all the characteristics of the typical section of the genus.

From the fresh-water strata that are referred to the Miocene epoch, only four species of Planorbis have yet been published, which, being the only known fossil species of that genus of later date than the Eocene, are the remaining species to be noticed in this article. Three of these are described by Meek \& Hayden from the White River Group in Dakota, under the names respectively of Planorbis vetustus, $P$. leidyi, and $P$. nebrascensis. $\neq$ They are illustrated on Plate 32. The remaining species§ was described by T. A. Conrad, under the name of $P$. lunatus, from "Bridge Creek, Oregon," where it was found associated with Zonites marginicola, mentioned on a following page. Copies of Conrad's figure are given on Plate 32.

Reference has already been made, in connection with a notice of Sphacrium rugosum and S.? idahoense, to two deposits similar to each other in their faunal contents, the one being found in the neighborhood of the Kawsoh Mountains, in Northern Nevada, and the other in Southern Idaho, which are regarded as of Miocene age. These strata have furnished a limited but interesting molluscan fauna, among the species of which are two that were described by Meek under the names respectively of Carinifox (Vorticifex) tryoni and $C .(V$.$) binneyi.\| Both these$ forms are illustrated on Plate 32.

Although, as has already been shown, the family Limnæidæ (to which Carinifex is here referred) flourished ever since Mesozoic time, no other fossil species of Carinifex have yet been found in strata of any age, and no representatives of that genus. are now known to be living in North America except a few upon the Pacific slope. If the Miocene lake, the deposits of which contain the two species of Carinifex which have just been noticed, had drained into what is now the hydrographic basin of the Mississippi, representatives of that type as well as those of its associate mollusca would no doubt now be found living there. But as the

* An. Rep. U. S. Geul. Sur. Terr. for 1878, Part I, p. 44, pl. 19, fig. 5.

†Proceedings U. S. Nat. Museum, vol. iii, p. 159.

$\ddagger$ For descriptions and figures of these three species by their authors, see U. S. Geol. Sur. Terr., vol. ix, pp. 600, 601, pl. 45, figs. 1, 2, and 3 .

Am. Jour. Conch, vol. vi, p. 315 , pl. 13, fig. 8.

\|U. S. Geol. Sur. 40th Parallel, vol. iv, pp. 187, 188, pl. xvii, figs. 11 and 12. 
type referred to is found among the living mollusca in Pacific drainage . waters, it may be fairly inferred that that Miocene lake was drained into western and not eastern oceanic waters. It should be remarked, however, that no representatives of some of the types which were associated with those ancient forms of Carinifex are now known to be living.

PHYSLDE.

The Physidx have been found to be comparatively well represented in nearly all the strata which have furnished any fossil pulmonate mollusca. Both Physa and Bulinus are represented by several species (all of which are regarded as extinct), ranging from the Cretaceous to the Miocene, inclusive. Notwithstanding their great antiquity, there seems to be among them all very little deviation from the types which are expressed by the numerous living species of those genera.

The earliest known species referable to the Physidæ is Physa carletoni Meek, ${ }^{*}$ which was obtained by him from the Cretaceous estuary deposit at Coalville, Utah, which has before been referred to in connection with Anomia propatoris, Cyrena carletoni, and Melampus: antiquus. P. carletoni is represented by a figure on Plate 5.

In many cases the earliest known species of a genus which is capable of subdivision into subordinate types or sections is not referable to that section which has been selected by naturalists as the typical one; but in the present case Physa carletoni seems to be a typical Physa, while some of the later species seem to depart more from the typical form. These facts are, however, of no great significance, because the section of a genus which is designated as typical is usually only conventionally selected; and, also, because we cannot know with certainty whether the earliest known species was in reality the earliest. Although only the one species just mentioned has yet been discovered in any strata of greater age than those of the Laramie Group (if we except a fragment which has been found in the marine Cretaceous strata at Coalville, Utah, and which was probably drifted to that position from the then adjacent shoret), we cannot doubt that the Physidæ were comparatively abundant in the Cretaceous period, because that species is so unmistakable in its generic characteristics, and also because it belongs to a type that Las reached the present time unchanged.

An unnamed form, which is probably a true Physa, has been found in the Bear River Laramie beds of Southwestern Wyoming, a figure of which is given on Plate $6 . \ddagger$

Plate 25 contains figures of a fine large species which Professor Cope obtained from the Judith River Laramie beds in the Upper Mis-

${ }^{*}$ An. Rep. U. S. Geol. Sur. Terr. for 1877, p. 306, pl. 7, fig. 12.

†U. S. Geol. Sur. Terr. for 1877 , p. 307 , pl. 7, fig. 13 . The figure is also given on Plate LXV, accompanying this article.

$\ddagger \Lambda$ n. Rep. U. S. Geol. Sur. Terr. for 1878, Part I, p. 85, pl. 30, fig. 11.

29 ( 
souri River region, and which I described under the name of Physa - copei.*

Some fragments of a Physa have been found in the Laramie strata of Crow Creek Valley in Colorado, east of the Rocky Mountains, that indicate a somewhat remarkable and interesting form. It was described by me under the name of Physa felix. $t$ The best example yet discovered is figured on Plate 25.

A species which occurs in the Wahsatch Group of Eocene strata in Southern Wyoming and adjacent parts of Colorado and Utah, and which reaches a greater size than any other known fossil Physa, perhaps excepting $P$. copei, has been described by myself under the name of $P$. pleromatis. $\ddagger$ The type specimen of the species is figured on Plate 30. Some imperfect specimens have been found in Colorado, apparently belonging to this species, that indicate a very much greater size. A partially restored figure of one of these is given on Plate 30.

Another fine species has been described by Meek from the Bridger Eocene group of Southern Wyoming, under the name of Physa bridgerensis. It is illustrated on Plate 30.

Physa pleromatis is apparently a typical Physa, but P. bridgerensis perhaps ought to be referred to Bulinus. For present convenience, however, it is referred to Physa.

From the Miocene White River Group of Dakota, Evans \& Shumard described Physa secalina, $\|$ which is represented on Plate 32. It has a very modern aspect, although it is regarded as an extinct species. No fossil Physa of later age than this has vet been published from any North American strata, but one or more species is known to exist in certain strata of Southern Wyoming and Northwestern Colorado, which Professor Powell has named the Brown's Park Group, and are probably of Pliocene age.

The genus Bulinus is well represented in the Laramie Group, but no other species of that genus has yet been published from any other North American strata, unless Physa bridgerensis should prove to be a Bulinus, as already suggested. Associated with Physa copei in the Judith River Laramie beds, Professor Cope found a fine large species of Bulinus which I described under the name of $B$. atavus. I It is figured on Plate 25.

From the Laramie strata, at the mouth of Judith River, Meek \& Hayden obtained the type specimens of Bulinus subelongatus; ** which is represented on Plate 25.

From the Fort Union Laramie beds two other specimens of Bulinus

"An. Rep. U. S. Geol. Sur. Terr. for 1878, Part I, p. 84, pl. 22, fig. 1.

tAn. Rep. U. S. Geol. Sur. Terr. for 1878, Part I, p. 84, pl. 22, fig. 1.

$\ddagger$ Expl. and Sur. West of the 100th Merid., vol. iv, p. 211; pl. xxi, fig. 1.

An. Rep. U. S. Geol. Sur. Terr. for 1878, Part I, p. 45, pl. 19, fig. 10.

॥ U. S. Geol. Sur. Terr. vol. ix, p. 604, pl. 45, fig. 4.

I An. Rep. U. S. Geol. Sur. Terr. for 1878, Part I, p. 86, pl. 24, fig. 5.

** U. S. Geol. Sur. Terr., vol. ix, p. 540, pl. 42, fig. 13. 
were described by Meek \& Hayden, under the names respectively of $B$. longiusculus and B.rhomboideus, ${ }^{*}$ both of which are represented on Plate 25. These two forms are so closely like Physa that they may apparently be with equal propriety referred to that genus. Indeed if these two species are properly referred to Bulinus, then Physa bridgerensis and one or two other species herein referred to Physa ought to be referred to Bulinus also.

In the Laramie strata, east of the Rocky Mountains, in Colorado, $B u$. linus disjunctus White, † occurs. It is represented on Plate 25.

Another Laramie species was discovered in Southern Utah by Professor Powell, which I described under the name of Physa kanabensis, $\ddagger$ but which ought to be referred to Bulinus. This species is yet known only by specimens that are too imperfect for satisfactory illustration.

\section{ANCYLIDE.}

The Ancylidæ, when present, always form an inconspicuous feature in any fresh-water fauna, and the family is represented by only two published species, so far as is now known, in all the North American strata. One of these species, Acroloxus minutus, Meek \& Hayden, was obtained by them from the Laramie strata near Fort Union, in the Upper Missouri River region. $\S$ It is illustrated on Plate 24.

The other fossil representative of the family is Ancylus undulatus, Meek, $\|$ from the Miocene deposit of the Kawsoh Mountains of Northern Nevada, where it was found associated with the two species of Carinifex that have already been mentioned, and also with certain other freshwater forms. It is represented on Plate 32.

In the Southern Idaho equivalent of the Eocene beds just mentioned, associated with Melania taylori, Lithasia antiqua, Sphorium rugosum, \&c., an interesting shell has been found which seems to agree with the genus Latia Gray, although that genus has hitherto been known only in certain portions of Oceanica, and only in the living state.

This form may be briefly characterized as follows:

Latia dallii (sp. nov.), plate 32 , figures $37,38,39$, and 40. Shell subovate in marginal outline; irregularly convex above; the posterior portion narrowing rapidly to a small prominent umbo, which ends in a very small, closely-incurved beak; the beak turned a little to the right side, and making about one full volution; semilunar shelf or septum comparatively large. Surface marked by many strong, irregular, concentric undulations; but otherwise it is comparatively smooth, being marked only by fine lines of growth.

*U. S. Geol. Sur. Terr., vol. ix, pp. 541, 542, pl. 43, figs. 16 and 17.

† An. Rep. U. S. Geol. Sur. Terr. for 1878, Part I, p. 86, pl. 24, fig. 6.

$\ddagger$ Powell's Rep. Geology of the Uinta Mountains, p. 119.

$\S$ U. S. Geol. Sur. Terr., vol. ix, p. 543, pl. 44, fig. 10.

|| U. S. Geol. Sur. 40th Parallel, vol. iv, p. 186, pl. xvii, fig. 12. 
Length, 16 millimeters; breadth, 10 millimeters; height, 7 millimeters.

The specific name is given in honor of Mr. W. H. Dall, whose important works upon the mollusca are well known.

VITRINIDE.

It is a suggestive fact that so large a proportion of the fossil nonmarine mollusca, which have been found in North American strata, are air-breathing land snails. This result of field-investigation is unexpected, both because individuals of none of the living land-snails are. found in as great numbers as many of the gill-bearing water snails are, and because all the specimens that have been preserved in the fossil state must have been transported from the land into the waters in the sediments of which they were preserved after the death of the mollusks which formed them. We must therefore conclude that in former geological epochs the land-snails were proportionally quite as abundant as they are now, and it seems probable, also, that the shores of, and the region round about, the Laraime sea, and those of the great fresh-water lakes which succeeded that sea, formed a peculiarly favorable habitat for land mollusca.

Judging from the character of a portion of the fossil shells that have been discovered, and from the wide diversity in the families of land mollusca, which is indicated by the collections that have been made from various formations, we cannot doubt that the family Vitrinidre was represented, at least during the Laramie and Tertiary periods. It is not to be denied, however, that with a knowledge of the shells only, and they usually more or less imperfect, it is not always possible to say with certainty that those which we refer to that family really belong to it; or that they may not belong to the Helicidø.

The three following-named species were described by Meek \& Hayden, and referred by them, not without some donbt, to the Vitrinidx. They obtained them from the Judith River Laramie beds of the Upper Missouri River region, and named them respectively, Vitrina? obliqua, Hyalina? occidentalis, and H. $\mathrm{H}$ evansi.* All three of these forms are represented by figures on Plate 27.

From the Wind River Group of Eocene strata, in Wyoming, Meek \& Hayden also obtained a fine large species, which they described under the name of Macrocyclis spatiosa, which is represented on Plate 30.

\section{ARIONIDEE.}

Among the most interesting remains of land mollusca that have been discovered are those which Dr. J. W. Dawson has published at different times from the Coal-Measures of Nora Scotia. Ho was the first to demon-

*U. S. Geol. Sur. Terr. vol. ix, pp. 545-548, pl. 42, figs. 6 and 7.

† U. S. Geol. Sur. Terr., vol. ix, p. 594, pl. 42, fig. 9. 
strate that a widely differentiated land molluscan fauna existed during the Coal Measure period, if not much earlier.

If the species which Dr. Dawson described under the name of Zonites priscus, * from the Coal Measure strata of South Joggins, Nova Scotia, is really a Zonites, or a closely related form, we have proof of the remarkable fact that the family Arionidæ was well established in the Carboniferous age. The correctness of the reference of this species to the Arionidæ being accepted, we naturally conclude that other members of the family have existed somewhere during all the time that has'elapsed since the Carboniferous age; but yet remains of no other representatives of the Arionidæ are now known to exist in any North American strata, if we except the one mentioned below. Copies of Dr. Dawson's original figures of Zonites priscus are given on Plate 2. His specimens were found associated with Pupa vetusta and P. bigsbyi Dawson, both of which species are mentioned in their order on following pages.

Mr. T. A. Conrad published a form under the name of Helix (Zonites) marginicola, $\nmid$ from Bridge Creek, Oregon, which probably comes from a fresh-water Eocene deposit. His specimens seem to have been very im. perfect and unsatisfactory. A copy of his figure is given on Plate 32.

\section{HELICID E.}

Among other molluscan remains that have been discovered in the Coalmeasure strata of Indiana and referred to the Pulmonata is a form to which Professor Bradley gave the generic name of Dausonella, describing the species under the name of $D$. meekii. $\neq$ Dr. Dawson, in commenting upon this form, expresses the opinion that it belongs to the Helicidø "near Helix (Triodopsis) palliata and H. (Stenotrema) monodon;"§ but Professor Whitfield expresses the opinion that it was an operculate shell resembling Helicina.\|

For present convenience, and without reference to the merits of the question raised, this species is here left where Dr. Dawson first placed it. It is in either case very probable that true members of the Helicidæ really did exist during the Coalmeasure epoch, contemporaneously with the Pupidæ which are known to have existed then, and which are presently to be mentioned. Darcsonella meekii is represented on Plate 2 by copies of Professor Whitfield's figures.

If Dawsonella should prove not to belong to the Helicidæ, the earliest examples of that family which are yet known to occur in North American strata are found in the Laramie Group. From the Judith River Laramie beds of the Upper Missouri region Meek \& Hayden obtained two species which are referred to this family. The first they described

*Am. Jour. Sci., vol. xx (3), p. 411, figs. 10 and 11.

†Am. Jour. Conch., vol. vi, p. 315, pl. 13, fig. 9.

$\ddagger$ Am. Jour. Sci., vol. iv (3), p. 88.

I Am. Jour. Sci., vol. xx (3), p. 413.

\|Am. Jour. Sci., vol. xxi (3), p. 127. 
as Helix vetusta, and the other under the name of Thaumastus limnaformis; * the first being represented on Plate 27 and the latter on Plate 25. The former is perhaps not a typical Helix, but the latter is probably a true representative of Thaumastus, as that genus is known among living mollusca. If so, it is the only fossil representative of the section of the Helicidæ to which it belongs that is at present known in North America strata (if. we except the Bulinus floridanus of Conrad from the Eocene of Florida and perhaps also the species mentioned on page 445 under the name of Limnoa (Limnophysa?) compactilis, although living species of Thaumastus are not uncommon in the southern part of North America.

From the Fort Union Laramie beds of the Upper Missouri River region Meek \& Hayden also described two species of Helicidæ under the names respectively of Columna teres and C.vermicula.' 'These also are the only representatives of their genus that are yet known in North American strata, and, like the next preceding species, no living congeners are found in North America so far northward as the localities from which the fossil species were obtained. Both these forms are represented on Plate 25.

From the Laramie strata of Southern Utah Professor Powell obtained a species of Helix that seems to possess the characteristics of the subgenus Strobila Morse, and which I have described under the name of Helix kanabensis. + It is figured on Plate 25. It was found associated with Physa kanabensis and Planorbis (Bathyomphalus) kanabensis, both of which have already been noticed.

A series of coal-bearing strata near Evanston, Southwestern Wyoming, which apparently belong to the upper part of the Laramie Group, have furnished a number of species of pulmonate mollusca, among which are two species of Helix, namely H. Sepulta and H. evanstonensis White.ई The former seems to possess the subgeneric characteristics of Patula Haldeman, and although its characteristics have been quite clearly ascertained, the specimens are all too imperfect for figuring. H. evanstonensis is apparently referable to the subgenus Triodopsis Rafinesque. It is figured on Plate 27.

From the Wind River Group, a series of fresh-water Eocene strata in Western Wyoming, a fine species was obtained by Meek \& Hayden and described by them under the name of Helix? veterna.\| It is represented by copies of Mr. Meek's figures on Plate 30. Certain characteristics presented by this shell cause some doubts-to arise as to its real

\footnotetext{
* For figures and descriptions of both these species seo U. S. Geol. Sur. Terr., vol. ix., pp. 552, 553, pl. 42, fig. 7; and pl. 44, fig. 8.

† U. S. Geol. Sur. Terr., vol. ix, pp. 555, 556, pl. 44, figs. 11 and 12.

$\ddagger$ Powell's Rep. Geology of Uinta Mountains, p. 120.

The first of these species was originally described in Proc. U. S. Nat. Museum, vol. iii, p. 160; and.tho other in Bull U. S. Geol. Sur. Terr., vol. iv, p. 714.

UU. S. Geol. Sur. Terr., vol. ix, p. 596, pl. 42 , fig. 8.
} 
affinities; but it is at present left with the Helieidæ, where those authors placed it.

Professor Powell obtained from the Bitter Creek Group, in Central Utah, the earliest of the fresh-water Eocene series, a species which I described under the name Helix peripheria,* and which appears to possess the subgeneric characteristies of Aglaia Albers. From the Eocene Green River Group of Southern W.yoming he also obtained H: ripariat White, which is apparently referable to the subgenus Arianta Leach. Both the last-mentioned species are figured on Plate 29.

Whether Helix kanabensis, H. sepulta, H. evanstonensis, H. peripheria, and $H$. riparia are correctly referred to the respective subgenera in conneetion with which they have just been mentioned, or not, their diversity of form gives sufficient indication that the Helicidæ had become widely differentiated during those early epochs in which they lived, probably quite as widely as their living representatives are, and under closely similar forms.

At present, the only known Miocene species of Helix is H. leidyi Hall \& Meek; which is also the only known fossil species of that genus of later date than the Eocene.ई It is represented on Plate 32.

PUPID EE.

If it were not that the existence of a diversified land molluscan fauna during the Coal-Measure period is a well-established fact, we should be slow to accept the conclusion of Dr. Dawson that the shell which he has described from the Erian (Devonian) plant-beds of St. Johns, New Brunswick, under the name of Strophites grandoevaई is really a land snail. In view of the factjust stated, and of the reasons which he gives for his conclusions, we seem to have no reason to doubt that the shell in question is, as hẻ suggests, closely related to Pupa. A copy of his figure of it is given on Plate 1.

Although an unexpectedly large number of species of non-marine mollusea has been obtained from strata so ancient as those of the CoalMeasures, the fact that the Gasteropoda are all land snails shows clearly that the complete non-marine inollusca of that period is very far from being fully known. It cannot be supposed that coördinate families, similar to those with which representatives of the speeies referred to are raneously with those ancient species which have been discovered. The known to have been afterwards associated, did not exist contempocontinental area, however, having been at that time smaller than it afterward became, the rivers were necessarily comparatively few and small. Therefore, the fresh-water mollusca, as compared with those of the land, were perhaps proportionally fewer then.

\footnotetext{
* Powell's Rep. Geology Uinta Mountains, p. 130.

+ Ibid.

† See mention of some California species of Helicidæ found in a fossilized condition under the head of spurious and doubtful species, on a following page.

$\S$ Am. Jour. Sci., vol. $x x(3)$, p. 413.
} 
Among the non-marine mollusca which have been discovered in the Coal-Measure strata of Canada and the United States are four species which belong to the Pupidx. Dr. Dawson was the first to recognize the pulmonate character of these mollusks, and he described the firstdiscovered species under the name of Pupa vetusta, the type specimens of which he obtained from the Coal Measure strata at South Joggins, Nova Scotia.* Copies of his figures of this species are given on Plate 2.

Professor Bradley described P. vermillionensis from the Coal-Measures of Indiana, and subsequently Dr. Dawson described a second species nnder the name of $P$. bigsbyit from the same strata and same locality in Nova Scotia that had furnished examples of $P$. vetusta. Both these species are represented by copies of Dr. Dawson's figures on Plate 2.

Within the present year (1881) Professor Whitfield has described a fourth Pupa-like form from the Coal-Measure strata near Marietta, Ohio, for which he proposed the new generic name of Anthraeopupa, describing the species under the name of A. ohioënsis.ई Copies of Professor Whitfield's figures are given on Plate 2.

Whether the species described as Pupa by Dawson and Bradley strictly belong to the typical forms of that genins, as it is represented by living species, or not, there seems to be no room for reasonable doubt that all four of the Carboniferous forms that have just been noticed belong to the family Pupidx. This being the case, it cannot be doubted that the family was well represented during all subsequent epochs; and yet no other fossil species besides these have been discovered in North American strata, except those which have been found in the fresh-water Eocene deposits of Southern Wyoming.

One of these Eocene species was described by Mr. Meek, from the Bridger Group, in Southern Wyoming, under the name Pupa? leidyi.\| The type specimen of this species seems to have been lost; and therefore no figure of it can be given. It evidently differed considerably from the typical forms of Pupa, and Mr. Meek was in doubt whether it might not with propriety be referred to Holospira Albers.

The remaining three species of the Pupidre to be noticed in this article were all obtained from the Green River Eocene Group at one locality, in Southern Wyoming. They have been published under the following names, respectively: Pupa incolata, P.arenula, and P. atavuncula White. IT

The first-named species seems to belong to the subgenus Leucocheila

"Acadian Geology, 1855, p. 160; Am. Jour. Sci., vol. xx (3), p. 405.

t Am. Jour. Sci., vol. iv (3), p. 87.

\pm Am. Jour. Sci., vol. xx (3), p. 410.

For generic diagnosis and specific description see Am. Jour. Sci. vol. $x \times$ (3), p.126.

IIAn. Rep. U. S. Geol. Sur. Terr., for 1872, p. 517 .

Tा For descriptions and figures of these three spccies, see $\Lambda$ n. Rep. U. S. Geol. Sur. Terr., for 1878, Part I, pp. 46, 47, pl.19, figs. 7, 8, and 9. 
Alb. \& Mart.; and the other two are referred provisionally to Pupilla Leach. All three of these forms are represented on Plate 29. Owing to the imperfection of the type specimens of these three species, their reference to the subgenera which have just been mentioned is not made with entire confidence; but whether this reference is correct or not, it is a well-established fact that the family Pupidro had acquired, as early, at least, as the earliest Eocene, nearly or quite all the characteristics which distinguish it at the present day.

\section{SUCCINIDE.}

Although so large a number and great variety of other land-snails have been discovered in the strata of various geological periods, only a single species referable to the Succinidæ has yet been found in North American strata. This is succinea papillispira, White, ${ }^{*}$ which was obtained from the upper portion of the Green River Eocene group in Southern Wyoming, and which plainly belongs to the subgenus Brachyspira Pfeiffer.

\section{NERITIDE.}

Since the greater part of the known species of this family, both living and fossil, are of marine origin, only those of its fossil representatives which are found associated with such forms as indicate that they lived in a brackish or nearly fresh water habitat will be considered in this article. The species thus falling under consideration embrace two subordinate types of Neritina and these only. One of the types is apparently identical with that of the common fluvatile living species of Neritina, which may be regarded as the typical section of the genus, $\nmid$ but the other type is extinct. Instead of having been confined to either brackish or fresh water, both these types have representatives in strata of both brackish water and marine origin. That is, for example, a species of each type is found in the Laramie group, associated with Corbicula, Corbula, Unio, and Melania. Other species of both types are found in Cretaceous strata, associated with such unmistakably marine forms as the Aviculidæ, Arcidæ, Turritellidæ, \&c.

'The earliest species referable to this family which is at present known, and which comes within the scope of this article, is Neritina nebrascensis, Meek \& Hayden, $\ddagger$ which was found in the vicinity of the Black Hills, in strata believed by those authors to be of Jurassic age. It is plainly a true Neritina, but those authors found it associated with species that are regarded as indicating a purely fresh.water habitat, namely, Unio, Viviparus, Lioplacodes, \&c. It is represented on Plate 3.

*An. Rep. U. S. Geol. Sur. Terr., for 1878, Part I, p. 45, pl.19, fig. 4.

+ The Laramie species, $N$. volvilineata, shows a faint crenulation of the border of the inner lip; and some small examples, apparently the young of this species, lately discovered, show a distinct denticulation of that border. Perhaps this species ought to be referred to Nerita, but for the present I leave it with Neritina.

$\ddagger$ Paleontology of the Upper Missouri, p. 109. 
The next species that are to be mentioned in the order of geological time are two that were discovered by Mr. Meek in the estuary deposit at Coalville, Utah, which has already been several times mentioned. One of these species was described by him under the name of Neritina bannisteri, ${ }^{*}$ and is represented on Plate 5. It is closely allied with the foregoing Jurassic species, and specimens of both have been found which still show the original color-markings of the surface. Neritina bannister $i$ has also a near ally in $N$. incompta White, from the marine Cretaceous strata of the same epoch, and which is found in the same region. Indeed, it is not improbable that these two forms are only varieties of one and the same species. If so, the fact implies that the species ranged from marine into brackish waters, with no more than a varietal change as a consequence.

Associated with this typical Neritina in the Cretaceous estuary deposit at Coalville is a species which Mr. Meek described under the name of N. bellatula; and with it, also, another form, which he named $N$. carditoides.t The type specimen of the latter is very imperfect; but, judging from the characters which it shows, it is thought to be identical with .7 . bellutula. Both the forms are represented on Plate 5.

These two last-named forms of Neritina belong to a sribordinate type to which Mr. Meek gave the subgeneric name of Velatella. The type is an extinct one, as has already been intimated, and is at present known only in Cretaceous and Laramie strata. $\ddagger$

In the Bear River Laramie beds a very small species occurs, which I have described under the name of Neritina naticiformis.ई It apparently belongs to the typical section of the genus. It is represented on Plate 7.

The Laramio species belonging to the subgenus Velatella, which has been referred to, was first discovered at Black Buttes Station, in Southern Wyoming, and described by me under the name of $N$. (V.) baptista. $\|$ Numerous specimens of it have since been discovered in the Laramie strata east of the Rocky Mountains in Colorado, all of which, including the type specimens, have preserved upon their surface the original color markings with which they were ornamented while living, and which are represented by Figs. 16-20 on Plate 23.

Associated with $N$. (V.) baptista, at the Wyoming locality, is the form which I have described under the name of Neritina volvilineata, II and which is illustrated on Plate 23. The type specimens were found in Southern Wyoming and Northwestern Colorado, none of which showed

\footnotetext{
*An. Rep. U. S. Geol. Sur. Terr. for 18i8, Part I, p. 25, pl. 12, fig. 10.

†For descriptions and figures of these two forms, see An. Rep. U. S. Geol. Sur. Terr. for 1878, Part I, pp. 27, 28, pl. 12, fiğs. 7 and 8.

$\ddagger$ For a diagnosis of this subgenus, see An. Rep. U. S. Geol. Sur. Terr. for 1878 , Part I, p. 27.
}

$\$$ An. Rep. U. S. Geol. Sur. Terr. for 1878 , Part I, p. 89 , pl. 30 , fig. 3.

\| An. Rep. U. S. Geol. Sur. Terr. for $18 i 8$, Part I, p. 89, pl. 29, fig. 6.

T An. Rep. U. S. Geol. Sur. Terr. for 1878 , Part I, p. 88, pl. 21 , fig. 6. 
the color markings such as are seen to characterize several species already noticed, and also the form referred to in the following paragraph.

Associated with. $N$. ( $\nabla$.) Baptista in Northern Colorado, east of the Rocky Mountains, is a form of Neritina which is closely related to $N$. volvilineata, which being undescribed I propose for it the name $N$. bruneri in honor of Mr. Lawrence Bruner, who first discovered the species. It differs from $N$. volvilineata in being somewhat more globose, having a less elevated spire, and the inner lips broader and less retreating. It is marked by revolving lines, somewhat like that species, but they are sometimes obsolete. It is also ornamented by zigzag colormarkings. The type specimen is represented by Figs. 14 and 15 on Plate 23.

Associated with the foregoing is still another form, much smaller, which seems to be the young of $N$. volvilineata. It is without color markings, and the inner border of the inner lip is dentate.

Although belonging to so early an epoch, these Laramie species of Neritina are the latest members of that family of non-marine origin that are now known to occur in North American strata. Consequently, no others besides those mentioned come within the scope of this article.

The typical form of Neritina has doubtless come down to the present day by securing a congenial habitat along the changing coasts of the growing continent; but although the subgeneric type Velatella existed before the inclosure of the Laramie sea, that sea seems to have embraced all the forms of that type which survived during the Laramie period. When, therefore, the waters of that sea became wholly fresh, that type, together with others, seems to have been extinguished as a consequence.

\section{CERITHIID 互.}

Only a single species, referable to this family, which may be regarded as a non-marine form, has been found in any North American strata. It was obtained from the Judith River Laramie beds, in the Upper Missouri River region by Meek and Hayden, and by them described under the name of Cerithidea nebrascensis.* Those authors referred it to the subgenus Pirenella Gray, but they expressed some doubt as to the true generic character possessed by the shell. Although Cerithidea is a well known living genus of the Old World, this species at present stands alone, or without near known allies, either living or fossil, among North American mollusca, if its generic relations are correctly understood, as stated above. It is represented on Plate 26.

\section{MELANIIDAE.}

Most naturalists agree in the opinion that no living North American species of mollusca are properly referable to the genus Melania; although formerly many species were referred to that genus which are now placed in the family Ceriphasiidæ, and mostly referred to the

* U. S. Geol. Sur. Terr., vol. ix, p. 559, pl. 43, fig. 9. 
genus Goniobasis. It has also been considered doubtful by many naturalists whether any one of the fossil species that have been found in the rocks of North America, ought to be referred to the family Melaniidx. The five or six following species, however, are in this article provsionally referred to that family; two because they are at present believed to strictly belong there; and the others partly because of their apparent affinities in that direction, and partly because they seem to be not properly referable to the Ceriphasiida. They are all interesting shells, embracing three distinct types, two of which, at least, are not known to have living representatives; but two of the species, while they appear to have no generic representatire living in North America, seem to be referable to true Melania of Old World type.

One of the species last referred to is Melania wyomingensis Meek, (= M. larunda White,*) which has been found on both sides of the Rocky Mountains in Southern Wyoming and Northern Colorado. Figures of this fine species are given on Plate 26.

The other species, which appears to be a true Melania, is M. claibornensis Heilprin, from the marine Eocene deposits of Alabama.t It is represented on Plate 28.

In Southern Wyoming Mr. Meek also obtained from the Laramie strata a form which he described under the name of Melania insculpta. $\ddagger$ It seems to be nearly related to $M$. wyomingensis, but difiers from it in wanting its prominent subspinous ornamentation. This species has also been found in the Laramie strata east of the Rocky. Mountains in Colorado, the specimens figured on Plate 26 having been collected in the valley of South Platte River.

There occurs somewhat abundantly in the Bear River Laramie beds of Southwestern Wyoming and the edjacent parts of Utah a shell which Mr. Meek first referred to Melania, but to which he afterward gave the new generic name of Pyrgulifera, describing it under the name of Pyrgulifera humrosa.ई It is illustrated on Plate 6. Mr. Meek placed this shell among the Ceriphasiidæ or American Melanians, but as it seems to differ quite as widely from the typical forms of that family as it does from the true Melanians, I here place it provisionally

- An. Rep. U. S. Geol. Sur. Terr. for 1878, Part I, p. 95, pl. 28, fig. 6.

tAlthough the associates of this shell are all marine, it is given a place in this articlo because Melania is generally regarded as a fresh-water genus. In this connection, however, it is proper to remark that among certain fossil faunæ shells undistinguishable from Melania are found associated with marine forms. (See Professor Heilprin's description and remarks, Proc. Acad. Nat. Sci., Phila., 1879, p. 214.) M. voyomingensis and $M$. insculpta have also been found in such associātion with Ostrea and Anomia, as to indicate that thoy all lived and flourished together in the same waters, which wero certainly in some degree saline, or the Ostrea and Anomia could not have existed there.

$\$$ See An. Rep. U. S. Geol. Sur. Terr. for 1878, Part I, p. 94, pl. 20, fig. 4.

$\$$ For diagnosis of this genus, and description and figures of the species, seo U. S. Geol. Sur. 40th Parallel, vol. iv, p. 146, pl. 17, fig. 19. 
with the latter family. It is the only known species of the genus which has been proposed to receive it, either fossil or living:*

From the fresh-water Miocene deposits, which have already been mentioned as occurring in Sou thern Idaho and in the vicinity of the Kawsoh Mountains, Mr. Meek described two forms and Mr. Gabb another, which they referred to Melania, Mr. Meek doing so with an expression of doubt but Mr. Gabb with none. Copies of their origin al figures of these forms are given on Plate 32.

Mr. Meek gave the names M. 8 sculptilis and M. 2 subsculptilist to his two species, and Mr. Gabb, that of Mr. taylori to the one he described. Conrad's $M$. decursa is probably a synonym of the latter.

All three of these forms belong to one and the same type, and perhaps represent only one species. This type differs considerably from the other types that have herein been referred to the Melaniadæ. The species belong to a fauna from which, as before stated, no genetic lines seem to have reached the present Mississippi drainage system, and, like a portion of their associates, are quite unlike any other North American species, either living or fossil. All the known species of that fauna are herein referred to and figured, but, for the purpose of separate view, their names are given, as follows: Melania? sculptilis, M. \& subsculp. tilis, M.? taylori, Lithasia antiqua, Carinifex, (Vorticifex) tryoni, $C .(\nabla$. binneyi, Ancylus undulatus, Sphorium rugosum, and S.? idahoense.

The genus Melanopsis Lamarck is not known among the living mollusea of North America, and until very lately it was believed to be also ; absent from all North American strata. A small shell from the Laramie strata east of the Rocky Mountains in Colorado, associated with Corbicula, Corbula, Melania, Neritina, Anomia and Ostrea, is here described for the first time, and referred provisionally to Melanopsis. It is evidently congeneric with the living Melanopsis costellata Ferussac, and also with the Eocene M. buccinoidea Ferussac; both from Western Europe.

Melanopsis 8 americana (sp. nov.), Plate 23, Figs. 21, 22, and 23.

Shell very small, sides straight, and meeting at the apex at an acute angle; volutions six or seven, those of the spire not convex, but so flattened as to show only a linear suture between them, which is somewhat irregular; proximal portion of the last volution gently convex,its length being more than half the entire length of the shell; outer lip thin, not expanded, its margin not distinctly sinuous; inner lip having a very strong callous nearly filling the distal end of the aperture, leaving a narrow groove between it and the margin of the outer lip, and gradually diminishing in thickness towards the proximal end of the aperture; aperture, as bounded by the outer lip and callous inner lip, rudely sub-

* Sce foot-note on page 464.

†U. S. Geol. Sur. 40th Parallel, pp. 195, 196, pl. 17, figs. 8 and 9.

$\ddagger$ Paleonotology of California, vol. ii, p. 13, pl. 2, fig. 21. 
elliptical, angular at its distal end, rounded at its proximal end, and terminating at the end of the columella in a distinct, narrow canal, which is slightly bent to the left. Surface marked only by faint lines of growth.

Length, 7 millimeters; diameter of last rolution, $3 \frac{1}{2}$ millimeters.

\section{CERIPHASIID 2 .}

The Ceriphasiidæ, or American Melanians, constitute an important feature of the non-marine fossil molluscan faunæ of North America, especially in the Laramie and Eocene fresh-water strata of the west. We have yet no evidence of the existence of this family before the Laramie period; but in view of its known abundance during that period, and also during that of the Eocene, it inay be safely assumed that the - origin of the family was at an earlier period. It is nevertheless true that the forms of Goniobasis, which occur in the purely fresh-water Eocene strata, somewhat more nearly resemble those which are regarded as typical forms among living species than most of those of the Laramie period do. This, however, may have little significance as regards physical changes since the Laramie, because the Uniones of that period are more characteristically like living Uniones than those of the Eocene strata are.

All except two or three of the fossil species that have been described as belonging to the Ceriphasiidr have been referred to the genus Goniobasis Lea; but a part of them have been so referred with some doubt. Among those concerning which no doubt of this kind has been expressed by the respective authors who have describud them, there may be recognized at least three somewhat distinct subordinate types perhaps worthy to be called subgenera.

Of these three types, Goniobasis cleburni White, G. tenera Hall, and G. nebrascensis Meek \& Hayden, may be regarded as representatives respectively; but I regard it as probable that the latter type is more nearly related to Lioplax than to Goniobasis.

The Bear River Laramie strata not only furnish what are probably the earliest known species of the Ceriphasiidx, but they furnish most of the known species, four in number, which may be referred to that proposed section of Goniobasis of which G. cleburni is the type.* The other three species are, respectively, $\dot{G}$. chrysallis Meek, G. chrysalloidea White, and G. macilenta White.t All four of them are figured on Plate 6. They are found associated together in the Bear River Laramie beds of Southwestern Wyoming and the adjacent parts of Utah, and none of them

\footnotetext{
*The species of this type bears some resemblance to Mclanopsis, but none of them are canaliculate at base in any degree. No examples of Melanopsis, except the one described on page 461 of this article, are known in North America, either fossil or recent; if we except the species Conrad deseribed as Bulliopsis.

tSee description and figures of these four species, together with other references, An. Rep. U. S. Geol. Sur. Terr. for 1878, Part I, pp. 91-93, pl. 30, fi.gs. 4, 5, 6, 7, aull 10.
} 
have been found in any other strata of the Laramie Group except those which are strictly equivalent with those beds.

One other species, which I have described under the name of Goniobasis endlichi, ${ }^{*}$ is found associated with the four species that have just been mentioned. It is represented on Plate 6 . This form belongs to another type, which includes $G$ : nebrascensis, presently to be mentioned, and which, as before suggested, probably belongs near Lioplax Troschel.

Five species were described by Meek \& Hayden from the Judith River Laramie beds of the Upper Missouri River region, under the generic name of Goniobasis, namely, G. convexa, G. invenusta, G. sublavis, G. omitta, and $G . ?$ subtortuosa, $\dagger$ all of which are represented on Plates, 26 and 27. It seems probable that $G$. sublocvis and $G$. invenusta are only varieties of $G$. convexa. $G$. omitta is much like $G$. gracilenta from the Fort Union beds, presently to be mentioned; but G.? subtortuosa is quite different from any other form that has been referred to Goniobasis. It probably belongs to some other genus, perhaps to Cassiopella White, which will be further mentioned on a following page, but that question cannot yet be determined because the characters of the base and aperture of the former are not yet known.

From the Fort Union Laramie beds of the Upper Missouri River region three species have been described by Meek \& Hayden, namely, Goniobasis gracilenta, G. nebrascensis, and G. tenuicarinata.t The two latter species have already been referred to as representing a separate section of the genus Goniobasis, if, indeed, they belong to that genus. They are represented on Plate 26. Both species have also been recognized in the coal-bearing strata at the town of Wakes, Utah, and $G$. tenuicarinata has been found in the Laramie strata of Crow Creek Valley in Northern Colorado, east of the Rocky Mountains. At the lastmentioned locality, as well as at Black Buttes Station in Southern Wyoming, Goniobasis gracilenta has been recognized. The species is represented on Plate 26.

It will thus be seen that thirteen species in all have been described and referred to Goniobasis from the Laramie (iroup alone. Even in case several of the specific names that have been applied to these forms should, as already suggested, prove to be merely synonyms, still it is clear that in the great Laramie Group there is a goodly number of welldefined species of Goniobasis, as that genus is now understood.

From the Laramie strata at Black Buttes Station, which have been so often mentioned, several specimens of a shell have been obtained, to

* An. Rep. U. S. Geol. Sur. Terr. for 1878, Part I, p. 92, pl. 30, fig. 7.

tFor descriptions and figures of these tive species, see U. S. Geol. Sur. Terr., vol.ix, pp. 562-570, pl. 42 .

$\ddagger$ For descriptions and figures of these three species, see U. S. Geol. Sur. Terr., vol. ix, pp. 565-568, plates 42 and 43. 
which I have given the generic name of Cassiopella," describing the species under the name of $C$. turricula. It is figured on Plate 23. Like Pyrgulifera, it is the sole representative of an extinct generic type.t It is umbilicate, and in this respect differs from any other shell that has been referred to the Ceriphasiidx. It is referred to that family only provisionally, and because there appears to be equal or greater objections to referring it to any other established family. It is so referred mainly because of its agreement in form, and the character of its outer and inner lips.

Passing now to the three groups of fresh-water Eocene strata, the Wahsatch, Green River, and Bridger groups, as they are developed in Wyoming, Colorado, and Utah, we find that the genus Goniobasis constitutes even a more conspicuous feature of the faunæ of those groups, as regards proportionate numbers of individuals, than it did in the Laramie period, although the number of species was so much greater then. Notwithstanding this great generic prominence, and also the fact that four species have been described by different authors from those fresh-water Eocene groups under the name of Goniobasis, $\ddagger$ I am not at present prepared to admit that more than one well-defined species has yet been found in any of the strata of those three groups. Taking this view, we must of course regard those forms which have been described as separate species, as only varieties of the first one described; although it cannot be denied that the variation is, in some cases, very considerable; and if intermediate forms had not been discovered, their specific separation would nerer have been called in question. In this view of the case I have selected tenera Hall as the specific name by which to designate this variable and abundant Eocene species of Goniobasis, because it was the first specific name that was applied to it by any author. It will be convenient and proper, however, to retain the other names as those of varieties, or even in some sense as species. For the same purpose I propose the name Goniobasis columinis for the extravagantly ornamented forms represented by Figs. 29 and 30 on Plate 31. A considerable series of these forms from different localities in those fresh-water Tertiary groups is given on Plate 31 , which shows the wide range of variation and the transition of the forms and the character of their ornamentation.

- For diagnosis of this genus and description and figures of the species, see An. Rep. U. S. Geol. Sur. Terr. for 1878, part I, pp.66,67, pl.27, fig. 3.

t Since these paragraphs were written, Mr. Edgar A. Smith has published, in the Proceedings of the Zoological Society of London, two species under the new generic name of Paramelania, found living in Lake Tanganyika, in Africa, which seem to bo congenerio with Pyrgulifera.

$\$$ These proposed species are respectively as follows: Goniobasis tenera (=Cerithium tenerum Hall), Fremont's Rep. Oregon \& N. California, p. 308, pl. III, fig. 6; G. simpsoni Meek, Simpson's Rep. Great Basiu Utah, p. 365, pl. v, tig. 1 ; G. nodulifera Meek (=Cerithium nodulosum Hall, Fremont, op. cit.), and G. carteri Conrad, An. Jour. Conch., vol. iv, p. 280, pl. 18 , figs. 6 and 7 . 
Although the genus Goniobasis has not been recognized in any of the strata of North America of later age than the Eocene, it cannot be doubted that it existed somewhere during the later epochs; probably in some of the streams which have since become upper branches of the Mississippi River system, where it is now abundant.

In the Miocene fresh-water deposit, which has been several times referred to as occurring in Southern Idaho and Northern Nevada, called the Truckee Group by King, no species of the genus Goniobasis have been recognized; but Mr. Gabb obtained a shell which he referred to Lithasia (a genus which is regarded as a member of the Ceriphasiidæ), and described it under the name of $L$. antiqua.* It is illustrated on Plate 32.

\section{RISSOID $A$.}

The Rissoidæ, in consequence of their small size and comparative rarity, form an inconspicuous feature of the non-marine fossil faunæ which are discussed in this articie; and jet they are interesting because they show that as early at least as the close of Mesozoic time several genera of that family inhabited the then existing fresh and brackish waters; and that the most of those which have been discovered are either congeneric with existing forms, or so closely like them, that we cannot properly do otherwise than refer them to existing genera, although we may entertain some doubt as to their real affinities. Up to the present time eight fossil species have been published and referred to this family, most of which were obtained from the Laramie Group.

Among these the two living genera Hydrobia and Bythinella are recognized, and also one new genus, Micropyrgus, which was proposed by Mr. Meek. ${ }^{\prime}$

Four species, Hydrobia subconica, $H$. anthonyi, $H$. enlimoides, and $H$. warrenana, were described from the Laramie strata of the Upper Missouri River region by Meek \& Hayden.f The first one comes from the Judith River beds, and the other three from the Fort Union beds. They are all illustrated on Plate 27. Except in the case of $H$. anthonyi, those authors express some doubt as to the true generic relations of these shells with Hydrobia, and reason for similar doubt seems to exist in relation to that species also. For present convenience, however, all four of these forms are left under Hydrobia, where those authors placed them.

The Fort Union Laramie beds also furnished Meek \& Hayden with the types of their Micropyrgus minutulus, $\S$ which they referred to the Rissoidæ. It is represented by copies of Mr. Meek's figures on Plate 26.

*Paleontology of California, vol. ii, p. 13, fig. 22.

tU. S. Geol. Sur. Terr., vol. ix, p. 574.

$\downarrow$ For figures and descriptions of these four species, see U. S. Geol. Sur. Terr., vol. ix, pp. 571-573, pl. 43.

$\S$ U. S. Geol. Sur. Terr., vol. ix, p. 575 , pl. 43, fig. 18 . $30 \mathrm{G}$ 
Among the species which occur in the coal-bearing beds near Evanston, Wyo., several of which species have already been herein noticed, there oceurs a slender form which I have described as Hydrobia recta.* It is represented on Plate 27.

Another species was obtained by Professor Powell from certain strata in Utah, which he then referred to the Bitter Creek Group, but which may probably prove to be of Laramie age. This form was described by me under the name of Hydrobia utahensis.t It is represented on Plate 27.

The only remaining species to be noticed under the Rissoidæ is Bythinella gregaria $\ddagger$ Meek; which was obtained from the fresh-water Eocene strata at Pacific Springs, Southern Wyoming, by Dr. Hayden. This species is also represented on Plate 27.

\section{VIVIPARIDE.}

Among the non-marine gasteropods of North America, no family is more conspicuous than the Viviparidæ, and, although this family ranks high in its class, it seems to have been fully established, essentially as it exists to-day, in the Jurassic period, and its origin was doubtless much earlier. It seems to have existed in greatest abundance in the Laramie and Eocene periods, but that is perbaps largely due to the fact that the conditions of their existence and preservation were greater then. After the Eocene, the preservation of the family doubtless took place in rivers, the great lacustrine waters of the continent having then passed away, or what remained seemed to have been uncongenial to Viviparine life.

The small collection of fresh-water shells which was obtained by Meek \& Hayden from near the Black Hills, and by them referred, with some doubt, to the Jurassic period, has already been mentioned in con: nection with Unio nucalis and Planorbis veternus. Two other species were included in that collection, namely, Viviparus gillianus and Lioplacodes veternus $§$ Meek \& Hayden, both of which forms are illustrated on Plate 3.

Besides the original specimens of Lioplacodes no other 1 epresentatives of the genus, either fossil or recent, have ever been discovered, and it therefore falls into the eategory of extinct types, a subject which will be briefly discussed on subsequent pages. These two species, being of Jurassic age, are the oldest members of the Viviparida that are yet known in North American strata.

No member of this family of Cretaceous age is jet known; and the next to be mentioned is a very large species from the Bear River

\footnotetext{
* Powell's Rep. Geology of the Uinta Mountains, p. 132.

† Powell's Geology of the Uinta Mountains, p. 132.

$\ddagger$ An. Rep. U. S. Geol. Sur. Terr. for 1878, Part I, p. 48, pl. 19, fig. 6 .

$\$$ For diagnosis of Lioplacodes, and deseription and figures of $L$. veternus and Viviparus gillianus, see Paleontology of the Upper Missouri, pp. 115, 116, pl. v.
} 
Laramie beds of Southwestern Wyoming and the adjacent parts of Utah, which I described under the name of Viviparus couesii.* It is represented on Plate 8.

The only species of Viviparus that is yet known to occur in the Judith River beds of the Upper Missouri River region is $V$. conradi Meek \& Hayden, $t$ which is illustrated on Plate 24; but the genus is abun. dantly represented in the Fort Union beds. Six species and one variety have been described by Meek \& Hayden from the latter beds, under the following names (figures of which are given on Plates 24, 25, and 27): Viviparus peculiaris, V. trochiformis, V. leidyi, V. leidyi var. formosa, $V$. reynoldsianus, $V$. leai and $V$. retusus. $\neq \mathbf{A}$ glance at these illustrations will show that the species they represent are evidently allied to each other, the relationship being so close in some cases as to suggest that future discoveries of specimens will probably reveal intermediate forms that must reduce the number of recognizable species by one-half at least.

A form similar to but shorter and more compact than Viviparus leai has been obtained from the Laramie strata of Crow Creek Valley east of the Rocky Mountains in Colorado, which is figured on Plate 25, and which I have described under the name of Viviparus prudentius. $\S$

From certain strata in Central Utah, probably belonging to the Laramie Group, Professor Powell obtained some forms of Viviparus which closely resemble $V$. trochiformis and $V$. leidyi, respectively, and with which they are probably identical.

At Black Buttes Station, in Southern Wyoming, Viviparus plicapressus || White, together with numerous other fresh and brackish water forms, have been found in the Laramie strata there, most of which have been mentioned on previous pages. This species is represented on Plate 24.

Another form, somewhat similar to $V$. trochiformis, to which I gave

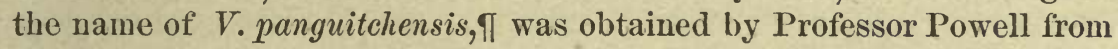
strata in Southern Utah, which, doubtless, belong to the Laramie Group. It is figured on Plate 25.

One of the most interesting species that has as yet been obtained from the Laramie Group is Tulotoma thompsoni** White, which has been found in Southern Wyoming, west of the Rocky Mountains, and also east of the same in Colorado. It is illustrated on Plate 24. It is referred to the genus Tulotoma Haldeman, rather than to Viviparus, because of its nodular ornamentation; but since the operculum has

*An. Rep. U. S. Geol. Sur. Terr. for 1878, Part I, p. 99, pl. 30, fig. 1.

†U. S. Geol. Sur. Ter., vol. ix, p. 579, pl. 42, fig. 15.

$\ddagger$ For descriptions and figures of all these forms, see U. S. Geol. Sur. Terr, vol. ix, pp. 577-584, pl. 44.

$\oint$ An. Rep. U. S. Geol. Sur. Terr. for 1878 , Part I, p. 98 , pl. 28, fig. 5.

॥ An. Rep. U. S. Geol. Sur. Terr. for 1878, Part I, p. 98, pl. 28, fig. 6.

I Powell's Rep. Geology Uinta Mountains, p. 123.

**An. Rep. U. S. Geol. Sur. Terr for 1878, Part I, p. 100, pl. 28, fig. 2. 
never been discovered, all its known characteristics, except the one mentioned, agree with Viviparus, from which genus some naturalists do not separate Tulotoma. There appears to be good reason, however, for separating the two groups as distinct genera among living North American mollusca; but it is nevertheless reasonable to suppose that they had a common origin in a single generic form in some one of the geological epochs. Such a community of origin, and probable original generic identity of these fossil Viviparine forms, is strongly suggested by comparing some of the specimens of $T$. thompsoni, upon which the nodules are only faintly developed, with typical specimens of $V$.trochiformis, which have a closely similar form and similar revolving ridges, but no nodules. Indeed, some of the characteristics are so strikingly alike in both these species that one can hardly resist the suggestion that they themselves present the examples of such a community of origin as las been supposed. If this really was the case, and we accept Tulotoma as a genus separate from Vivipurus, we have an example of the evolution of a new generic form. without a break in a recognizable line of descent. In other words, it is a case in which the generic and specific divergences in the line of descent were coincident, the former being the more distinct of the two, at least in the features presented by the shell.

From certain strata in Utah, which were referred to the Tertiary, but which probably belong to the Laramie Group, I described a species of Viviparus, under the name of $V$. ionicus; * but all the known examples of it are very imperfect.

In the Eocene fresh-water strata of the West, perhaps the most abundant species next to Goniobasis tenera Hall, with which it is constantly associated, is Viviparus paludinceformis Hall. $t$ This species has been found especially plentiful in those strata of Colorado, Wyoming, and Utah. It presents some degree of variation in different districts, and in different layers at one and the same locality ; but it is not nearly so variable a shell as is its associate Goniobasis tenera. Illustrations of $\boldsymbol{V}$. paludinaeformis are given on Plate 30.

The only remaining species of Vivaparus to be regularly noticed in this article is $V$. vyomingensis Meek; $\ddagger$ which is figured on Plate 30. It has been found only in the Bridger Group, where it is comparatively rare.ई

The differences which are recognizable between the shells of living species of Viviparus and Campeloma, respectively, are quite as distinetly discernible among the fossil forms which are noticed in this article. Recognizing the two genera as separate and distinct, we find, as one of the earliest known North American species of Campeloma, a form that

"U. S. Expl. and Sur. West of the 100th Merid., vol. iv, p. 215, pl. xxi, fig. 6.

$\nmid$ Fremont's Rep. Oregon and N. California, p. 309, pl. iii, fig. 13.

\$Proc. Acad. Nat. Sci. Phila., vol. i, (3), 1871, p. 182.

\$Seo references to $V$. lyelli Conrad, V. glabra H. C. Lea, and Paludina subglobosa Emmons, on a subsequent page, under the head of spurious and doubtful species. 
was described by Meek from the Bear River Laramie beds of Southwestern Wyoming, under the name of C. macrospira.* It is illustrated on Plate 8.

Meek \& Hayden obtained from the Judith River Laramie beds of the Upper Missouri River region a species to which they gave the name of Campeloma vetula; $t$ and examples of the same species have also been recognized in the Laramie strata at Black Buttes Station, in Southern Wyoming. It is illustrated on Plate 27.

Two other species of Campeloma, namely, C.multistriata and $O$. multilineata Meek \& Hayden, were originally described from the Laramie strata near Fort Clarke, in the valley of the Upper Missouri. $\ddagger$ Both forms are represented on Plate 27. The former has also been somewhat doubtfully recognized at Black Buttes Station, in Southern Wyoming, and the latter in the valley of Crow Creek, east of the Rocky Mountains, in Colorado.

Among a collection of Laramie fossils made several years ago in the valley of the Yellowstone River by Mr. J. A. Allen are some examples of Campeloma multistriata that show the species to be much more variable than was indicated by the description and figures given by Meek \& Hayden. Some of these have the typical form and characteristics as described by them, but others are strongly shouldered at the distal side of the two last volutions. Examples of these are given on Plate 27.

Associated with the foregoing are numerous examples of a very variable species, some of which examples have the characteristics of Campelo$m a$, except that they are more than usually elongate, and some of them appear to lave the characteristics of Lioplax, Troschel. The species represented by these specimens appears to have never been described, and I therefore apply to it the name of Campeloma (Lioplax ?) producta, indicating the form represented by figures 21 and 22 on Plate 26, as the type. Figures of the associated forms, and which perhaps belong to the same species, are also given on the same plate.

Shell, elongate-ovate; test, moderately thick; spire, more than usually produced for a species of this genus; volutions, six or seven, usually slightly flattened, or having a faint revolving depression upon the distal sille near the suture, which is more apparent upon the larger than the smaller volutions; suture, deep and abrupt upon the proximal side; aperture and lips having the usual characteristics of Campeloma or Lioplax; surface, marked by the usual lines of growth, and by somewhat numerous revolving strix which are often obscure, but upon the smaller rolutions of some of the examples a few of the striæ are so strong as to produce a faint angularity. Among these examples are others which possess the general characteristics of those which are regarded as the

*See An. Rep. U. S. Geol. Sur. Terr. for 1878, Part I, p. 102, pl. 30, fig. 2.

† U. S. Geol. Sur. Terr. vol. ix, p. 587, pl. 42, fig. 14.

$\ddagger$ U.S. Geol. Sur. Terr., vol. ix, pp. 586 and 588, pls. 43, fig. 15, and 44, fig. 1 
types; but two or three of the revolving strix upon the smaller volutions of these examples are much more prominent than in the case of typical examples. I at present, however, regard these as only varieties of a very variable species. Examples of this variety are illustrated with the others on Plate 26.

The collection made by Mr. Allen also contains Viviparus trochiformis and $V$. retusus and $V$. leai M $H_{\epsilon e k} \&$ Hayden, and Unio senectus White.

VALVATID无.

The Valvatidæ like the Rissoidæ are inconspicuous among the fossil non-marine faunæ of North America, but the family which is essentially a fresh-water one, seems to have become established at least as early as Mesozoic time. Indeed, although the Valvalida are among the more highly organized of the fresh-water mollusca, they seem to have coexisted with the earliest fresh-water gill-bearing mollusks that are yet known to us.

Among the fresh-water Jurassic fossils that were obtained by Meek \& Hayden from the vicinity of the Black Hills, and which have been already several times mentioned on previous pages, is a form to which those authors gave the name of Valvata scabrida, * and which is the earliest known species of that genus in North American strata. It is illustrated on Plate 3, by a copy of Meek's figure.

The next known species in the order of time is $V$. nana Meek, $\nmid$ which was obtained by him from the Cretaceous estuary deposit at Coalville, Utah, which has before been mentioned. It is illustrated on Plate 5 .

From the Judith River Laramie beds of the Upper Missouri River region, Meek \& Hayden descriłed a form under the name of Valvata? montanaensis; and from the Fort Union beds of that region, two others, under the names, respectively, of $V$. subumbilicata and $V$. parvula. $\frac{7}{5}$ The latter is probably only a variety of the former. All three of the last named forms are illustrated on Plate 27 by copies of Meek's figures.

For the purpose of presenting the subject of the foregoing pages synoptically, the following table has been prepared. It is intended as a list of all the known species of the fossil non-marine mollusca of North America; and is also intended to show the geological position of each species, and consequently the present known range in geological time, of the families and genera to which they belong. The names of the divisions of geological time used in this table will be found explained on page 414 et seq.

In making up the following list, preoccupied names, and generic names which have been wrongly used, are onitted, but such as are regarded as

*Paleontology of the Upper Missouri, p. 113, pl. iv, fig 2.

† See An. Rep. U. S. Geol. Sur. Terr. for 1878, Part I, p. 33, pl. 12, fig. 17.

$\$$ For descriptions and figures of these three forms seo U. S. Geol. Sur. Terr., vol. ix, pp. 590-592, pl. 42, and woodouts. 
synonyms that have been made such by mistaken identification of species are given in italics. It is probable that several other like synonyms still remain among those that are not italicised, but it is not thought best to thus characterize them without further investigation, because, as has been already remarked, this article is not a revision of these faunæ, but merely a review. Those which are enumerated under the head of spurious and doubtful species on subsequent pages are purposely omitted from this list. Materials for large additions to this list will, without doubt, be obtained through future operations of the Survey, and from other sources. 


\section{TABULAR VIEW OF THE NON-MARINE IOSSIL MOLLUSCA}

OF NORTH AMERICA.

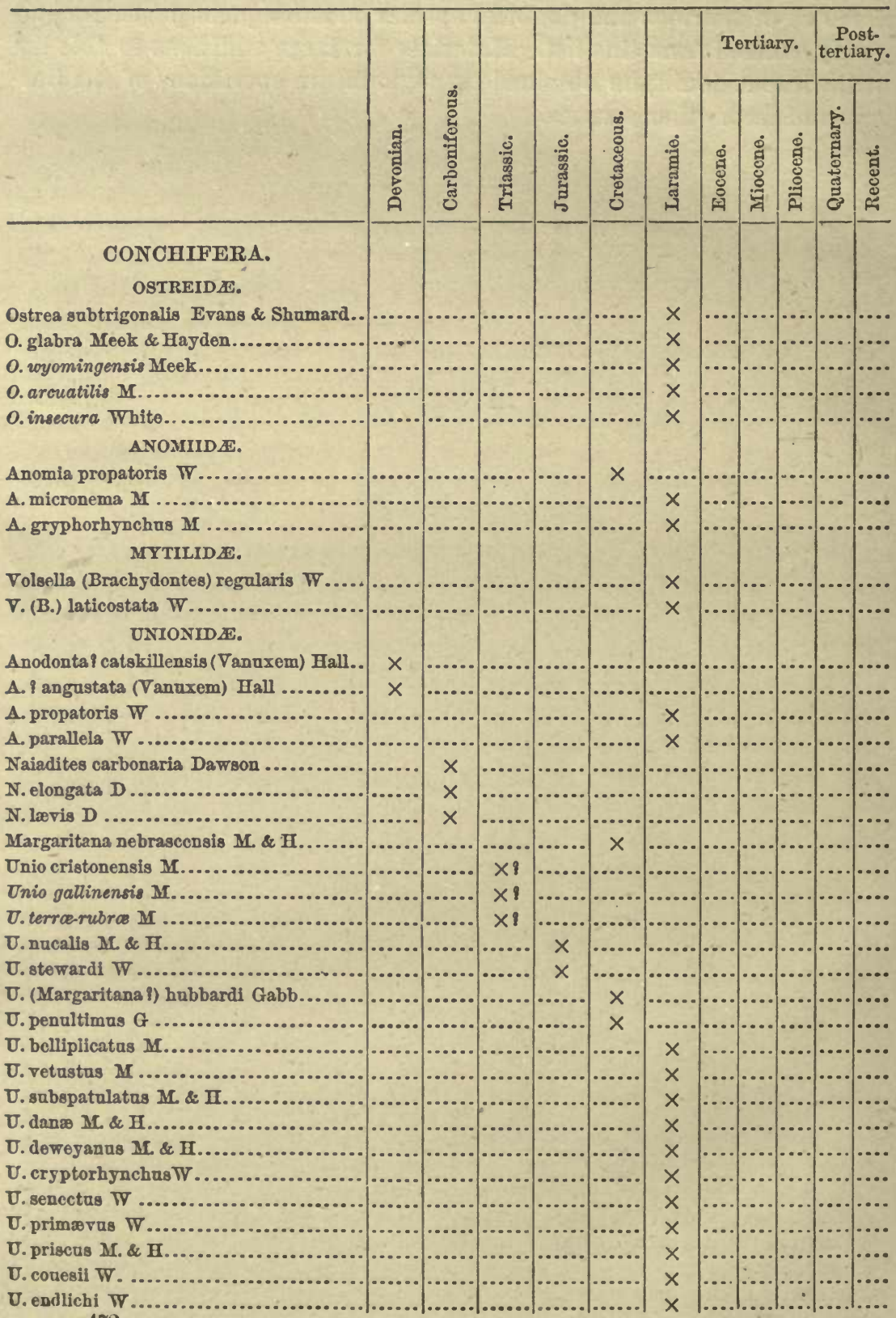


Tabular view of the non-marine fossil mollusca of North America-Continued.

\begin{tabular}{|c|c|c|c|c|c|c|c|c|c|c|c|c|}
\hline & \multirow{2}{*}{ - } & \multirow[b]{2}{*}{ 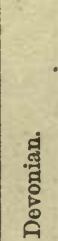 } & \multirow[b]{2}{*}{ 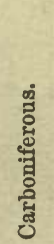 } & \multirow[b]{2}{*}{ 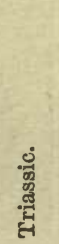 } & \multirow[b]{2}{*}{ 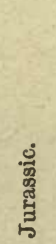 } & \multirow[b]{2}{*}{ 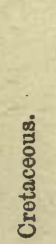 } & \multirow[b]{2}{*}{ 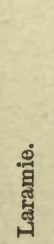 } & \multicolumn{3}{|c|}{ Tertiary. } & \multicolumn{2}{|c|}{$\begin{array}{l}\text { Post- } \\
\text { tertiary }\end{array}$} \\
\hline & & & & & & & & 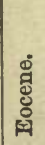 & 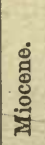 & \begin{tabular}{l}
$\dot{0}$ \\
$\stackrel{0}{0}$ \\
$: 0$ \\
\hdashline
\end{tabular} & 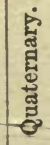 & 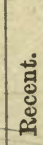 \\
\hline
\end{tabular}

CONCHIFERA-Continued.

UNIONIDE-Continued.

Unio propheticns White.

U. brachyopisthus $\mathrm{W}$

U. proavitus $\mathrm{W}$

U. aldrichi W

U. goniambonatus W

U. holmesianus W

U. gonionotus W.

U. mendax W

U. clinopisthus TV

U. meekii W

U. shoshonensis W.

U. washakiensis Meek.

U. haydeni M

U. tellinoides Hall.

\section{CYRENIDE.}

Cyrena dakotensis Meek \& Hayden C. carletoni $\mathbf{M}$.

Corbicula (Veloritina) durkeei $\mathbf{M}$

C. occidentalis $\mathbf{M}$. \& $\mathrm{H}$.

\section{O.bannisteri $\mathrm{M}$.}

C. cytherifurmis M. \& H

C. nebrascensis M. \& H

C. (Leptesthes) fracta M. \& H.

C. (L.) subelliptica M. \& H.

C. (L.) macropistha W

C. (L.) planumbona $\mathbf{M}$.

C. umbonella $\mathbf{M}$.

C. augheyi TV

C. berthoudi W

C. cleburni W

C. obesa W

C. cardiniæformis TV

Sphærium planum M. \& H

S. recticardinale M. \& H.

S. formosum M. \& H.

S. subellipticum M. \& H.

S. ragosum $\mathbf{M}$.

S. $\{$ idahoënse $\mathbf{M}$.

PISIDIIDAE.

Pisidium saginatum W CORBULIDAE.

Corbula pyriformis $\mathbf{M}$.

O. onglemanni $\mathbf{M}$.

C. nndifera $\mathrm{M}$

C. undifera, rar. subundifera W

.


Tabular view of the non-marine fossil mollusca of North America-Continued.

CONCHIFERA-Continued.

CORBULIDA-Continued.

Corbula subtrigonalis Moek \& Hayden.

C. perundata M. \& H.

O. crassatelliformis Meek.

O. tropidophora $\mathrm{M}$.

O. mactriformis $\mathrm{M}$ \& H

\section{GASTEROPODA.} AURICULIDE.

Melampus? antiquus $\mathbf{M}$.

Rhytophorus priscus $\mathbf{M}$.

R. meekii White.

\section{IMN XID AE.}

Limnæa (Limnophysa) nitidula $\mathbf{M}$

L. (Acella) haldemani W.

L. (Pleurolimnæa) tenuicostata $\mathbf{M}$

L. vetusta $\mathbf{M}$.

I. similis $\mathbf{M}$.

L. (Leptolimnea) minuscula W

I. meekii Evans \& Shumard

I. shumardi M.

L. (Polyrhytis) kingii M.

Planorbis veternus M. \& H.

P. convolutus M . \& H.

P. (Bathyomphalus) amplexusM. \& H.

P. (B.) planoconvexus M. \& H.

P. (B.) kanabensis W

P. (Gyranlus) militaris W

P. utahensis $\mathbf{M}$

P. spectabilis $\mathbf{M}$.

P. cirratus W

P. æqualis $\mathrm{W}$.

P. vetustas M. \& H.

P. nebrascensis E. \& S.

P. leidji M. \& H.

P. lunatus Conrad.

Carinifex (Vorticifex) tryoni $\mathbf{M}$.

C. (V.) binneyi M.

\section{PHYSIDAE.}

Physacarletoni $\mathbf{M}$.

P. copei W

P. felix W

P. pleromatis $\mathrm{W}$

P. bridgerensis $\mathrm{M}$

P. secalina E. \& $\mathrm{S}$

Bulinus atrvus W

B. subelongatus M. \& H.

\begin{tabular}{|c|c|c|c|c|c|c|c|c|c|c|}
\hline \multirow[b]{2}{*}{ 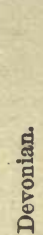 } & \multirow[b]{2}{*}{ 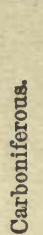 } & \multirow[b]{2}{*}{ 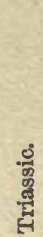 } & \multirow[b]{2}{*}{ 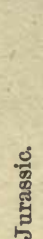 } & \multirow[b]{2}{*}{ 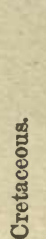 } & \multirow[b]{2}{*}{ 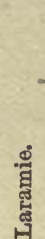 } & \multicolumn{3}{|c|}{ Tertiary. } & \multicolumn{2}{|c|}{$\begin{array}{c}\text { Post- } \\
\text { tertiary }\end{array}$} \\
\hline & & & & & & 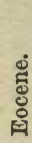 & 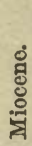 & 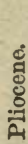 & 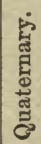 & 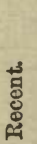 \\
\hline
\end{tabular}


Tabular view of the non-marine fossil mollusca of North America-Continued.

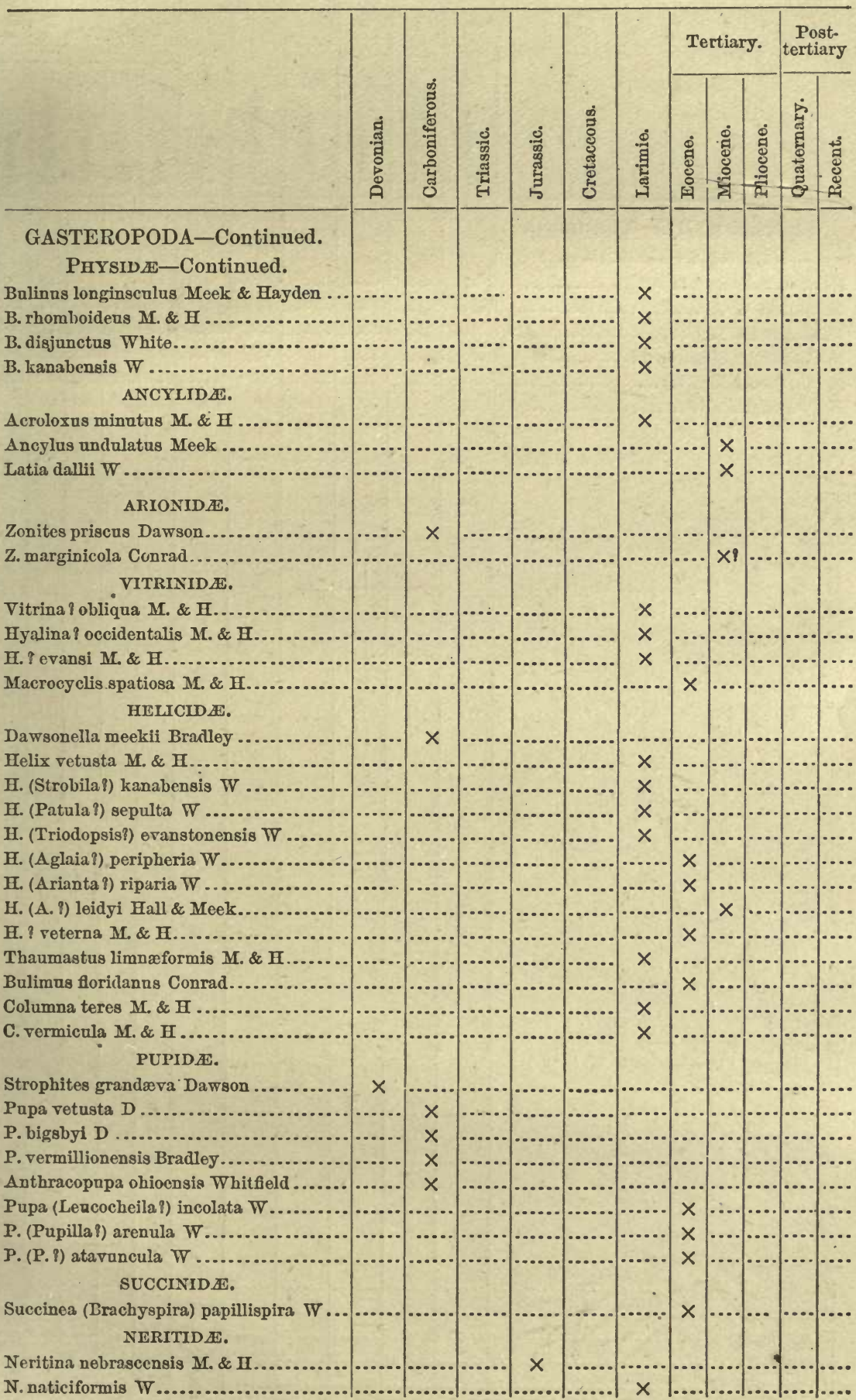


Tabular view of the non-marine fossil mollusca of North America-Continued.

\section{GASTEROPODA-Continued.}

\section{NERITIDE-Continued.}

Neritina volrilineata White.

N. bruneri W

N. bannisteri Meek

N. (Velatella) bellatula M.

$N$. ( .) carditoides $\mathbf{M}$

N. (V.) baptista W

\section{CERITHIDID.}

Cerithidea nebrascensis Mcek \& Hayden. MELANIID EE.

Melania wyomingensis M

M. claibornensis Heilprin

ar. larunda W

M. I insculpta $\mathrm{M}$.

M. I sculptilis M.

M. s subsculptilis $\mathbf{M}$

1C. I taylori Gabb.

Pyrgulifera humerosa M.

Melanopsis ? americana W

\section{CERIPIIASIID E.}

Goniobasis cleburni if.

G. chrysallis $\mathbf{M}$

G. chrysalloidea W.

G. macilenta W

G. (Lioplax i) endlichi W

G. convexa M. \& H.

G. invenusta M. \& H

G. sublovis M. \& H

G. omitta M. \& H

G. ? subtortuosa M. \& H.

G. gracilenta $\mathbf{M}$

G. (Lioplax ?) nebrascensis M. \& H

G. (Lioplax ?) tenuicarinata M. \& H .

G. tenera Hall.

G. nodulifera M

G. simpsoni $\mathbf{M}$.

G. carteri Conrail

Lithasia antiqua $\mathrm{Gabb}$

Cassiopella turricula W

\section{RISSOID E.}

Hydrobia subconica $\mathbf{M}$.

II. anthonyi M. \& H.

H. eulimoides $\mathbf{M}$

H. warrenana $\mathbf{M}$. \& H

H. recta W.

II. utahensis $\mathrm{W}$

\begin{tabular}{|c|c|c|c|c|c|c|c|c|c|c|}
\hline \multirow[b]{2}{*}{ 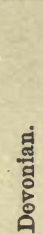 } & \multirow[b]{2}{*}{ 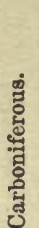 } & \multirow[b]{2}{*}{ 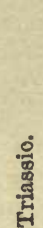 } & \multirow[b]{2}{*}{ 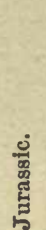 } & \multirow[b]{2}{*}{ 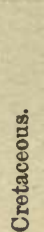 } & \multirow[b]{2}{*}{ 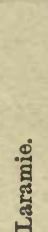 } & \multicolumn{3}{|c|}{ Tertiary. } & \multicolumn{2}{|c|}{$\begin{array}{c}\text { Post- } \\
\text { tertiary. }\end{array}$} \\
\hline & & & & & & 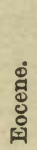 & 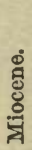 & $\begin{array}{l}\dot{\delta} \\
\text { हू } \\
. \\
\dot{\bar{A}}\end{array}$ & 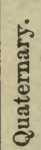 & 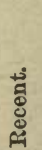 \\
\hline
\end{tabular}

$x$

$x$

$x$

$x$

$\times$

$\times$

$x$

$x$
$\times$

$x$

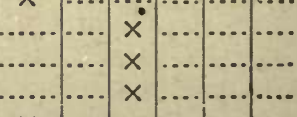

$x$

$x$

$x$

$x$

$x$

$x$

$x$

$x$

$x$

$x$

$x$

$x$

$x$

$x$

$x$

.......

$x$

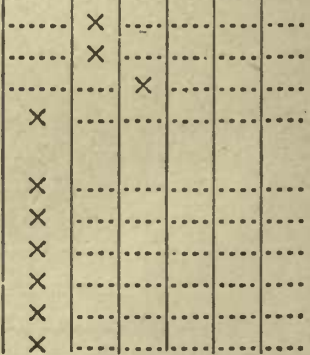


Tabular view of the non-marine fossil mollusca of North America-Centinued.

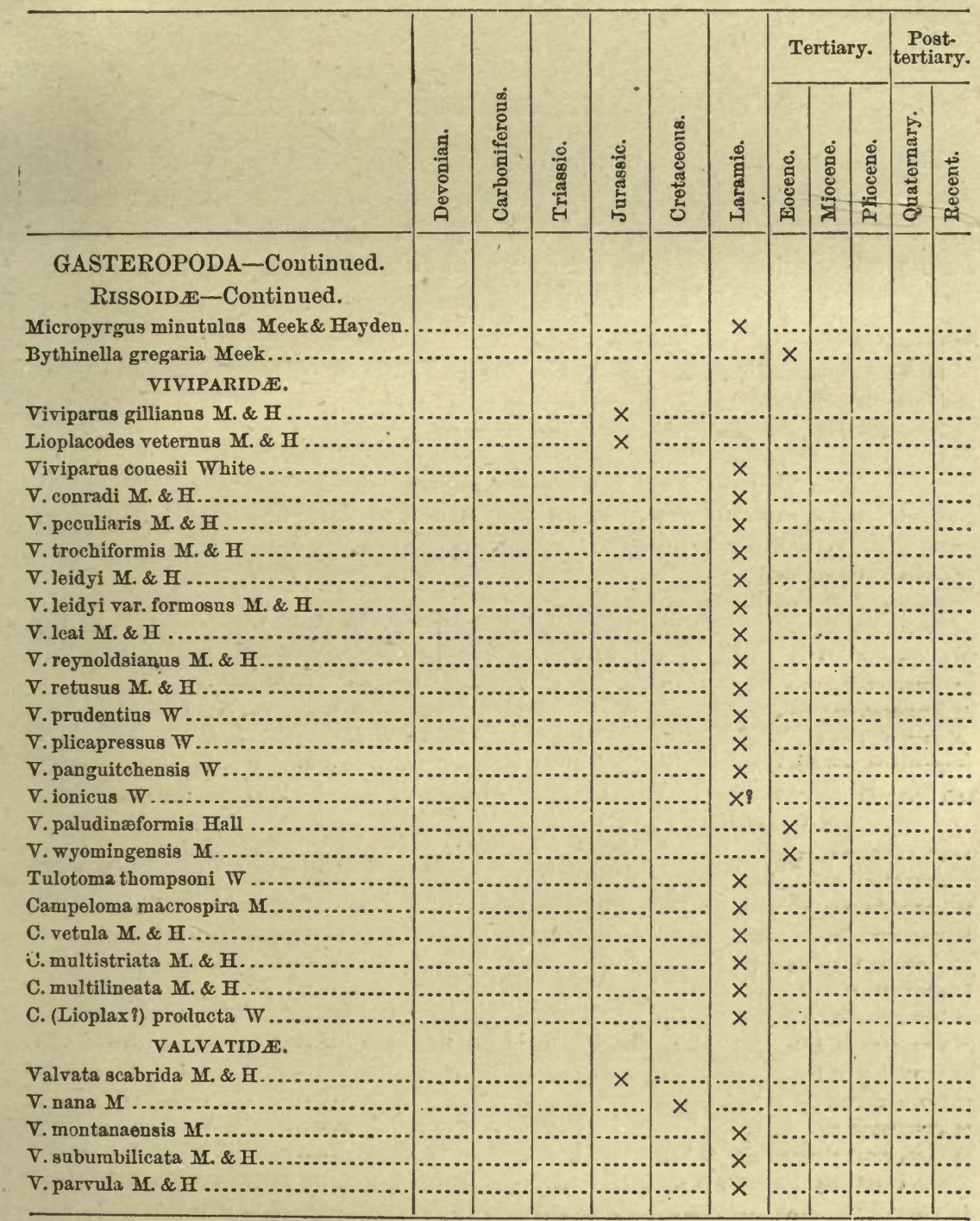




\section{SPURIOUS AND DOUBTFUI SPECIES.}

The species mentioned in the following notes were not included in the foregoing list because a part of them do not belong to the non-marine mollusca as they were supposed to do by the authors who first described them; concerning the true character of others there is some room for doubt, and the published information concerning the remainder is either unsatisfactory or erroneons.

In the Annual Report of the Geological Survey of New York for 1839, pp. 65, 66, Mr. T. A. Conrad published descriptions of four species of mollusks from the Medina Sandstone (Upper Silurian) under the names respectively, of Planorbis trilobatus, Cyclostoma pervetusta, Unio primigenius, and $U$. orthonotus. All these are now known to be marine species, and to belong, respectively, to the genera Bucania, Pleurotomaria, Cypricarlites,? and Modiolopsis.

In the American Journal of Science and Arts (1.), Vol. XXIX, p. 149 et scq, Plate 1, Figs. 17-22, Dr. S. G. Morton briefly described and rudely figured five forms which he named, respectively, Unio petrosus, U. tumulatus, U. terrenus, U. saxulum, and Anodonta hildrethi; and which he reported as having been obtained from Coal-measure strata in southern Ohio. If these fossils were really obtained from Coal-measure strata, our present knowledge of the fauna of that period, at least as it was developed in the region indicated, unakes it improbable that they were correctly referred to the genera Unio and Anodonta. It is more probable that they were obtained from a post Tertiary deposit, and that they really belong to living species.

In the proceedings of the Academy of Natural Sciences of Philadel. phia, 1368, pp. 162-164, Dr. Isaac Lea described ten species under the following names, respectively: Unio nasutoides, U. radiatoides, U. subrotundoides, $U$. cariosoides, $U$. humerosoides, $U$. roanokoides, $U$. ligamentoides, U. alatoides, Anodonta grandioides, and A. corpulentoides. They were obtained from a deposit in New Jersey which Dr. Lea regarded as "Lower Cretaceous," but which is almost certainly of post Tertiary date. Moreover, they probably belong to the living species, the resemblance to which is so plainly indicated by the respective names which Dr. Lea applied to them.

In Paleontology of California, Vol. II, p. 88, Mr. Gabb speaks of laving found the following species of Helix in a fossil condition, in different parts of that State, part of them being referred to strata of Pliocene age, although the species are all now living in that region : Hclix fracta Neweomb, H. hildebrandi Newcomb, II. mormonum Pfr., $H$. tryoni Neweomb, and $H$. tudiculata Binney.

Mr. H. C. Lea described a shell under the name of Turbo glaber in the 478 
Transactions of the American Philosophical Society, Vol. IX, p. 267, Plate 37, Fig. 87, which Mr. Conrad stated in Proc. Acad. Nat. Sci. Philad. 1862, p. 567, to be identical with the Paludina subglobosa of Emmons (Geology of North Carolina, p. 273, Fig. 186). This assumed identity is doubtful. The latter is probably either a Viviparus or a Campeloma. The former is probably neither.

From the Eocene strata of Wilmington, North Carolina, Sir Charles Lyell obtained the natural east of a shell which he referred to Paludina and published (Jour. Geol. Soc. Lond., Vol. I, p. 431) a figure of it, but without a specific name. Conrad subseqquently (Am. Jour. Conch., Vol. I, p. 32) gave the name Viviparus lyelli to this form. It is probably a true Viviparus, but its characters are not sufficiently known to settle the question definitely.

In Fremont's Report on Oregon and Northern California, pp. 308, 309, Plate III, Professor Hall has figured and deseribed several forms which have not beeu mentioned in the body of this article. They probably belong to a fresh-water fauna, although it was supposed that they were of marine origin when they were described. The specimens he had wero evidently imperfect, but $I$ have never seen them, and I have been unable by aid of Professor Hall's descriptions and figures to identify the species which they represent among any collections made in the West. The following are the names given them by Professor Hall in the work cited: Nucula impressa (?), Cytherea parvula, Plemotomaria uniangulata, Cerithium fremonti, Natica(?) occidentalis, and Turritella bilineata.

In Vol. III, p. 10, American Journal of Conchology, Mr. T. A. Conrad published a description and figure of a shell from the Carbonifer. ous strata of Kansas, under the new generic name of Prisconaia, referring it to the Unionidæ. It is probably a species of Schizodus, and therefore belongs to the Trigoniidæ.

In Vol. VI, of the same Journal, Conrad described Melania decursa and Anodonta decurtata "from Colorado." Because he did not state any locality or formation from which they were obtained, these species are not include in the text of this article. The former is probably from Oregon and identical with M. taylori Gabb.

\section{GENERAL DISCUSSION.}

Upon the preceding pages $I$ have presented a synopsis of all the known fossil nou-marine mollusea of North America, in the course of which it has been shown that many of the types now recognizable among the living non-marine mollusks have great antiquity; but that certain of the types which have been recognized only among the fossil species, and are therefore regarded as certainly extinct, were contemporaneous with many of those which survived. Before closing this 
article it will be proper to present some general discussion of the nature of the relations which these fossil forms bear to each other and to those now living, and to make some suggestions as to the probable lines of descent of the latter, and the causes of the destruction of those which have failed to survive.

In the present state of general knowledge of the subject, it seems hardly necessary to state in detail that these relations are regarded by naturalists as genetic in their character, and that the various forms which we discover, both living and fossil, have been evolved from preexisting primary forms. If the theory of the evolution of organic things is to be accepted in any sense, it seems necessary to conclude that molluscan life began in the sea, and that all fresh-water and land mollusca have been primarily derived from those of marine origin.*

While it is not my purpose to discuss this theory as such, it will be necessary, in the course of the remarks which are to follow, not only to refer to some of the phases which the subject presents when viewed in relation to the probable origin and distribution of the non-marine fossil mollusca, but it will also be necessary to adopt that theory at least as a working and explanatory hypothesis. Indeed, without an hypothesis of this kind, the structural relations which we find to exist between those fossil forms among themselves and between the fossil and living forms are meaningless and unimportant. With the acceptance of such a theory investigations like these become part of the elucidation of a grand history which has fortunately been self-registering and subject to errors only of interpretation arising mainly from imperfection of evidence.

If, as has been premised, the first molluscan life began in the sea, and the first non-marine mollusca were evolved from those which originated in marine waters, we may well inquire whether at least a part of those non-marine forms which subsequently existed had not also a similar origin, and whether we may not consequently regard the great tide of

* It is well known that in the case of some families of living mollusca, while certain species will thrive in brackish waters, none of them will livo in perfectly fresh waters. Living examples of this fact are common, and some have becn observed among the Laramie fauna. But too many facts are known concerning the ability of other mollusks to pass from saline to fresh waters, to leave room for reasonable doubt that the fresh-water mollnsca were primarily derived from the marine. Moreover, the evidence seems conclusive that many species whose living congeners are found exclusively in fresh waters were in former geological epochs able to live in waters that were more or less saline. It is the opinion of the writer also that in all or nearly all cases where marine types of mollusks, fishes, \&c., have been found in brackish and fresh waters, or their remains in deposits of such origin, they have become habituated to such waters by having been landlocked by the rising sea-bottom around them. That is, they were probably forced to conform to a change of habitat that they would not have voluntarily chosen. It is probable also that, as a rule, the fresh water mollusca have been developed as such by compulsion of this character and not by voluntarily forsaking marine for fresh waters. Onco doveloped as purely fresh water mollusca, certain forms at least became incapable of a return to marine waters; but certain other forms seemed capable of surviving a partial but not completo freshening of the waters. 
non-marine molluscan life that has come down to us from the past as having been made up of many contributing streams which had the sea as their source, rather than regard it, figuratively speaking, as a stream having an ancient and perhaps single source, augmenting in volume and throwing off from itself numerous branches which became collateral lines of descent. It is reasonable to suppose that both these conditions of evolution have prevailed, namely, that while some of the genetic lines of the non-marine mollusca may, and doubtless do, run back to paleozoir. time, the families of non-marine mollusks have had many accessions from the sea from time to time during the successive geological ages, and that each of these accessions was, at least potentially, the source of subsequent collateral lines of descent. But the question of the primary origin of these lines of descent is not an essential one in these discussions, because I propose now only to consider the evidence that they have existed, and make some inquiry into the character and relations of certain of those lines which may be regarded as directly lineal. In these inquiries I shall treat coincidences of structure among the fossil and recent shells which come under consideration not only as indications but as proof of genetic relationship; and this relationship as fundamentally pertaining to the geological and zoological history of the molluscan life which they represent.

It is true that the incompleteness of the material which is or that we may ever hope to have available for study is so great as to leave many gaps, at least in the details, of the life-histories of all the types which have been recognized among the fossil mollusca.

When, therefore, we come to trace the probable lines of succession of the various types of non-marine mollusks, we are met with certain difficulties, both apparent and real; and in endeavoring to account for the mauner in which those lines may have been preserved unbroken through successive geological periods, the difficulty seems especially great, when casually considered, in the case of the fresh-water gillbearing mollusca.

The prevalence of the sea has always been practically universal; and the various movements which the earth's crust has undergone since life began in the sea, while they have repeatedly disturbed or destroyed the habitats of its molluscan denizens in certain localities, and have broken many of the lines of genetic succession of types that had from time to time become established, there has evidently never been anything like such a general destruction of life in the sea as would either break or materially interfere with the greater part of the principal lines of such succession. In short, the marine field for the development and perpe. tuity of molluscan life has been ample and unbroken from the beginning to the present time, and we are at no loss to understand how continuous lines of genetic succession of its denizens may have extended down through all the geological ages, modified, it is true, by immediately environing and cosmical causes, but still unbroken. We may at least $31 \mathrm{G}$ 
conclude that if every molluscan species that now exists in the sea has not been lineally derived from the earliest molluscan forms that have existed in it, there have been no such changes of its physical conditions as would preclude such a possibility.

When we come to the-study of the fossil pulmonate mollusca, especially the laud-shells, we have also little or no difficulty in understanding how it has been possible for continuous lines of existence of these mollusks to be preserved through successive geological periods upon any continental area, such for example as North America, notwithstanding the numerous and great physical changes that have taken place within its area during those periods. Being air-breathers, nothing has apparently occurred to prevent their safe migration to other ground whenever that which they may have at any time occupied became uncongenial by reason of physical changes, because, as a rule, those changes were effected so slowly that a continuity of congenial habitat for such mollusks was not necessarily broken. They were thus apparently as capable of preserving a continuous existence through successive geological periods as the marine mollusca were.

But, as before intimated, when we come to the study of the fossil shells of the fresh-water gill-bearing mollusca, which in their living state must necessarily have been confined to fluvatile and lacustrine waters, it is not easy to understand, without a special explanation, how continuous genetic lines could have been preserved (as we find they were preserved even down to the present time) through a succession of geological periods, during which the great lakes, as we know, and all the rivers, as is generally but erroneously believed, in which those mollusks lived, have been successively obliterated. * Rivers are separated from each other by intervening land, and; running to the sea, their mouths are separated by marine waters, neither of which barriers are fresh-water gill-bearing molluska capable of passing. But if it can be shown that throughout those geological periods and down to the present time there has been direct continuity of fresh water by means of lakes or rirers, or both, the case is plain enough. Indeed, as precarious as the existence of continuous life of that kind may seem to hare been, under the circumstances of such vast physical changes as are known to have occurred, we are forced to conclude that it is in this direction that we must seek for an explanation of the manner in which were preserved

"It may be suggested that the distribution of these forms from one river or river system to another, may have taken place by the transportation of the mollusks or their eggs by aquatic birds. While such transportation is admitted to have been possible in some cases, it cannot be admitted as a probable cause of any considerable part of the distribution that must have occurred during the several geological epochs in which the molluscan types referred to are known to have existed. Notwithstanding the annual migration of myriads of aquatic birds between the northern and sonthern portions of North America at the present time, and doubtless also ever since It has been a contiuent, the fresh-water molluscan faunæ of those regions, respectively, are still distinct. 
the fresh-water molluscan types that have been found in the various groups of North American Mesozoic and Cenozoic strata, and that ${ }^{\circ}$ we also find among living mollusca. That is, ther have been preserved through a continuity of habitat in the congenial fresh waters of lakes and rivers, flourishing in the lakes, when they existed, as well as in the rivers, and escaping by the streams which were the former outlets and inlets of the lakes, but which continued to flow after the obliteration of the latter, as rivers or tributaries of river systems.

Lakes are only parts of unfinished river systems which disappear by being drained when the system is finished by the gradual wearing down of its channel. A lake consequently contains essentially the same aqueous fauna that the fluvatile portion of the system does in case the water of the lake is wholly fresh; or a modification of that fauna if the waters of the lake are more or less saline. The great lakes which existed in Western North America in the Tertiary and Laramie periods successively became obliterated, but we may reasonably conclude that at least a part of the rirer channels of to-day have existed as such from earlier geological times; that the greater part of them were established in epochs anterior to our own, and that those of some of the tributaries of the present Mississippi River system are identical, at least in part, with former outlets or inlets, or both, of the great ancient lakes which have just been referred to. Consequently we may reasonably conclude also that the molluscan fauna of the Mississippi River system is lineally descended from the faunæ of those ancient lakes, and the river systems of which they constituted lacustrine portions.* 'This view is confirmed

*I here include the Laramie Sea in the use of the term "lacustrine," the term "sea" being used simply to indicate that its waters" were saline and not fresh; just as the Black and Caspian are called seas instead of lakes, and for the same reason. It may seem to be the use of a misnomer to speak of the Laramie Sea as a part of a river system, because it was so immensely large, and the continental area which was drained into it was proportionally so small, but if these views concerning the conditions which then existed are correct, that sea, with its tributaries and outlet, differed only in degree and not in kind, from any river system which has a lake of any size in its principal course. The waters of that sea having been saline, the Laramie hydrographic system more nearly resembled that of the Black Sea than any other now existing that is equally well known; and, although the ancient sea has long since disappeared from the face of the earth, its "Hellespont" still flows as a part of the Missouri River, or of some one of its tributaries.

The commingling of brackish-water and fresh-water fossil forms in an estuary deposit is readily explained by the supposition that the river which debouched into the estuary brought down the latter and mingled them with the former. Bnt the commingling of brackish-water and fresh-water forms occurs in some portions of the Laramie deposits under such conditions as to compel the belief that some of them at least lived and thrived together. There is evidence also that the fresh-water fauna proper of the Laramie system not only inhabited the streams which emptied into its sea, but that in great and shifting areas of the sea itself the waters were sufficiently fresh to allow the existence in them of such mollusks as Unio, Goniobasis, Viviparus, Campelomia, \&c., and saline enough in other parts for the existence of Ostrea, Anomia, Corbula, \&c. This view of the conditions of the Laramie Sea being accepted it is plainly seen to have been, what Ritter has aptly termed, an unfinished river system, though an extremo example. 
by the identity of the living with the fossil molluscan types, which has already been referred to.

Rivers have of course existed ever since a sufficient extent of continental surface was raised above the sea to accunulate the waters that fell from the clouds; and in view of the mighty changes that have taken place during the progressive growth of the North American continent, especially the elevation of its great mountain systems and plateaus, it would be natural to suppose that the earliest rivers at least have been obliterated. Some have no doubt been obliterated, but contrary to what has been the general belief, the recent labors of Powell, Dutton, and others have shown that the rivers of North America lave been among the most persistent of its physical features; that many of them are older than the mountain ranges of the regions which the rivers traverse, and that they have not yielded their "right of way" when the mountain ranges and plateaus were raised, but continued during and after that elevation to run in essentially the same lines which they had chosen when the region they traversed was a plain instead of a mountainous one. That ancient river systems have been in some, and perhaps many instances, to a greater or less extent divided, as a consequence of unequal continental elevation, or from other eauses, is quite certain; and it was doubtless in part by this means that the dispersion of fresh. water mollusca into different river systems has been effected. That some formerly existing rivers with their lacustrine portions have been obliterated and their molluscan faunæ destroyed is doubtless also true, but these facts do not necessarily affect the correctness of the view concerning the general persistent integrity of rivers and river systems which has been referred to.*

The coalescence of separate minor drainage systems by the confluence of their lower portions into a common channel during the progressive elevation of the continent has also been an important means of the dispersion of fluvatile mollusca. By such coalescence, what were once seperate rivers or minor drainage systems became parts of larger ones; as, for example, the union of the separate peripheral members of the great Mississippi River system, which now forms a common drainage for the principal part of the continent. The Ohio and Upper Mississippi, the two most ancient portions of the present great system, were once separate rivers, emptying into a northern extension of the Great Gulf; and it is practically certain that neither of them received that portion of the mol-

* The discovery of so few traces of fluvatile deposits as have been made among the strata of the earth is probably due to the persistent adherence of rivers to their aneient channels. When land upon which rivers have formerly run has subsided beneath the level of the sea, the fluvatile deposits were doubtless destroyed by the encroaching marine waters. If the land continued to rise, as has been 80 generally the case in the gradual production of the North American continent, the earlier river deposits were swept away in later times by their own waters, as their valleys were broadened. and deepened. It is therefore, as a rule, only in the deposits of lacustrine portions of ancient rirer systems that their faun have been preserved. 
luscan fauna, which now so strongly characterizes them, until after the confluence with them of the western portions of the present great river system which brought that fauna from its ancient home in the western part of the continent.*

Rivers having been thus persistent, and the manner in which confluence of the waters of many of them has been effected being understood. it is no more remarkable that the types of fresh-water gill-bearing mollusea have come down to us from former geological periods practically unchanged, than it is that marine and land mollusea have reached us bearing the imprint of their really ancient, but what we have been accustomed to call, modern types.

The manner in which the various types of molluscan life have probably come down to the present time from former geological periods having been pointed out, we come next to inquire to what extent the views thus expressed are confirmed by $a^{\circ}$ comparison of the living with the fossil non-marine mollusea. As regards the fresh-water and land mollusea, it may be stated without hesitation that those views are fully confirmed by such a comparison. That is, we find between the fossil and living faunæ such an extensive agreement of types as to compel the conclusion that the former represent the latter ancestrally. It is true our investigations have shown that some of the types of freshwater gill-bearing mollusea which existeci in Mesozoic and Cenozoic time are not represented among living forms, having become extinct; but every family, almost every if not every genus, and many of the subordinate divisions of those genera that are known among living North American fresh-water mollusca, have been recognized among the species that constitute the different faunæ, the fossil remains of which have been collected from the Mesozoic and Cenozoic strata of Western North America.t These investigations also show the interesting fact that while considerable numbers of types among the mollusca referred to have been from time to time extinguished, the extinguishment having in some instances taken place as late as the Pliocene epoch, few or no new ones appear to have been introduced to replace any of them

* These remarks are made with especial reference to the Unionidx ; but they are also applicable to other gill-bearing mollusca, and they will no doubt apply with equal torce to at least a part of the ichthyc fauna of that great river system. The progenitors of the ganoids now living in that river system were doubtless originally landlocked in the Laramie sea, continued through the fresh water Eocene lakes, and finally escaped to the present river system in the manner already suggested.

t The extinctions referred to seem to have been caused by a failure of the waters in which the lost types lived, to secure a continuous flow into any existing river system, This is of course equivalent to supposing an exception to the rule already announced. that rivers have been persistent; but such exceptions being well authenticated would only add strength to the argument in favor of the rule. The portion of the Laramio Group known as the Bear River beds, and the Miocene Truekeo Group of Nevada, Idaho, and Oregon, both containing extinct types, may be taken as iudicating a failure of the waters in which they were respecticely deposited to secure persistent continuity during subsequent time. 
since the closing epochs of Mesozoic time. Fresh-water mollusca ap pear to have been less subject than marine mollusca to those cosmical influences which, from age to age and from epoch to epoch of geological time, progressively impressed the marine mollusca with their wonderful diversity of form and structure.

While so large a proportion of the types among the fossil fresh-water and land mollusca are clearly recognized among those now living, a large proportion, if not the greater part of the fossil brackish-water types which are presented in this article are different from those of the corresponding fauna now living. This is doubtless due to the fact that the lines of succession of most of the brackish-water mollusca, the remains of which we have had opportunity for study, were denizens of the brackish-water Laramie Sea, and were cut off by the final freshening of its waters, from which there was no escape to the coasts of the open sea, where they might have liad a congenial habitat, while their contemporaries of the land and fluvatile waters survived. This fact has been mentioned on previous pages in connection with the presentation of the several types referred to. It is, however, a remarkable fact that at least five of the types that are recognized among the fauna of the Laramie Group, namely, Bathyomphalus, Cerithidea, Pyrgulifera, Melanopsis, and true Melania, have'never been found among the living fauna of North America, but are represented by living species in the old world. But this and other questions pertaining to the Laramie invertebrate fauna will be discussed in a monograph of that fauna now in preparation. 


\section{PLATE 1. DEVONIAN.}

\section{Strophites GRANDeVA Dawson. (Page 455.)}

Fic. 1. Fragment, enlarged. The small outline to the left shows the natural size. After Dawson.

$$
\text { Anodonta? angustata (Vanuxem) Hall. (Page 424.) }
$$

FrG. 2. Right side view, natural size.

Fig. 3. Dorsal view of same. After Vanuxem.

Anodonta? Cattskillensis (Vanuxem) Hall. (Page 424.)

Fig. 4. Right side view, natural size. After Vanuxem. 

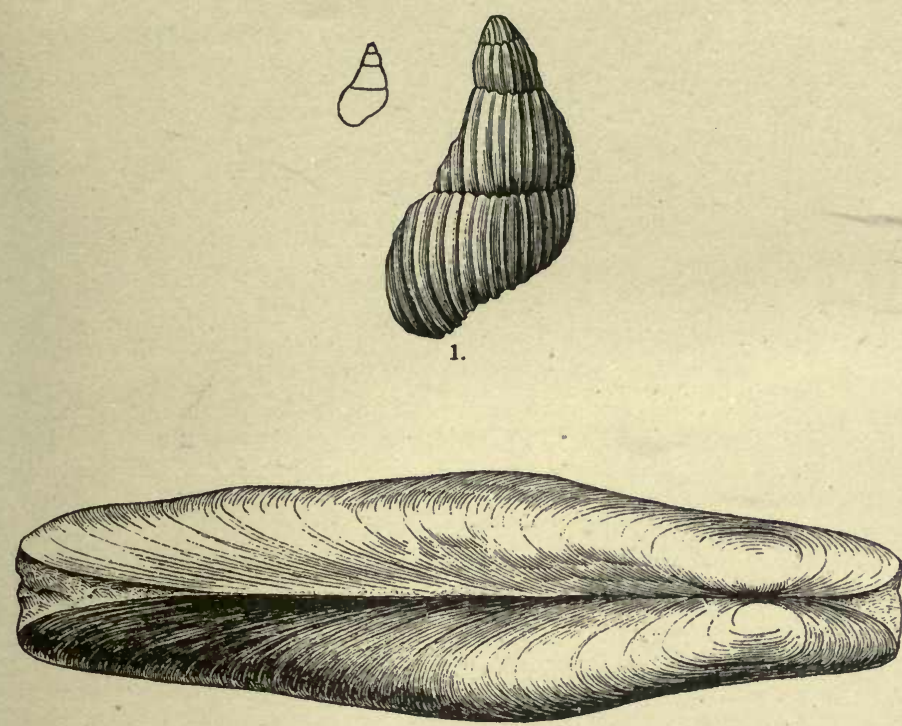

3.

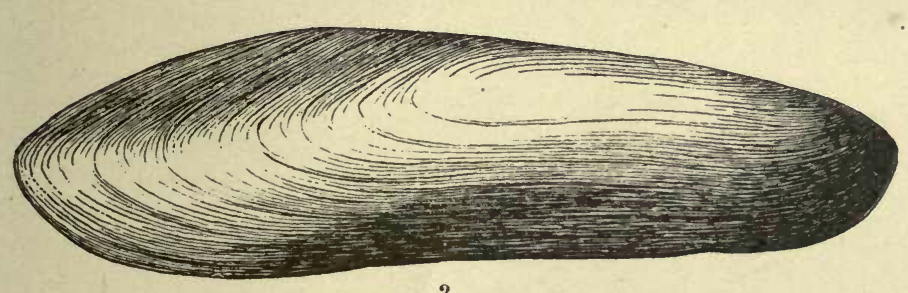

2.

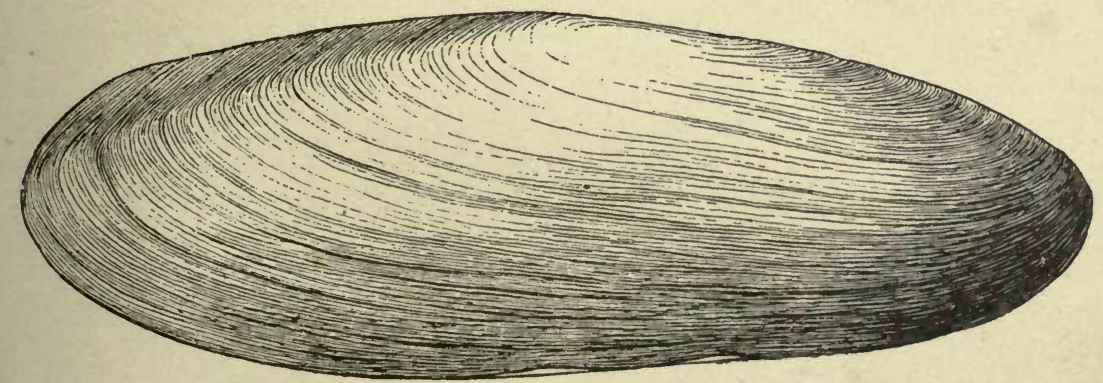

4.

DEVONLAN. 

PLATE 2. CARBONIFEROUS.

Pưa vetusta Dawson. (Page 456.)

FrG. 1. Lateral viow, enlarged.

Fra. 2. Apertural view, enlarged. After Dawson.

Dawsonella MEeki Bradley. (Page 453.)

Frg. 3. Apertural view, enlarged.

Frg. 4. Oatline of under view, enlarged. After Whitfield.

ANThracopupa omroensis Whitfield. (Page 456.)

Fic. 5. Lateral view, enlarged.

FrG. 6. Lateral view, outline showing edge of outer lip.

Fig. 7. Lateral view, outline showing aperture.

FIG. 8. Outline view of aperture, more enlarged. After Whitfield.

\section{PUPA BIGSBYI D. (Page 456.)}

Fig. 9. Lateral view, enlarged.

Frg. 10. Lateral view of a smaller example, enlarged. After Dawoon.

Zonites PRiscus D. (Page 453.)

FIG. 11. Lateral view, enlarged.

FrG. 12. View showing the aperture, enlarged. After Dawson.

Pupa vermillionensis B. (Page 456.)

Fig. 13. Lateral view, enlarged.

Fig. 14. Lateral view, showing the aperture, enlarged. After Dawson.

\section{Naiadtes carbonaria D. (Page 425.)}

Fig. 15. Left side view, natural size. After Dawson.

\section{Natadites elongata D. (Page 425.)}

Fig. 16. Right side view, natural size, and enlarged. After Dawson.

\section{Naiadites lavis D. (Page 425.)}

FiG. 17. Left valve enlarged, and smaller examples of natural size. After Dawson. 
U. S. GEOLOGICAL SURVEY

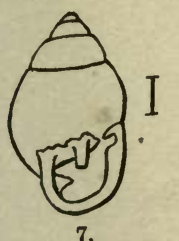

7.

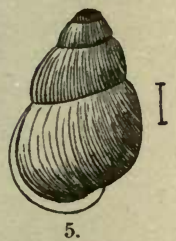

5.

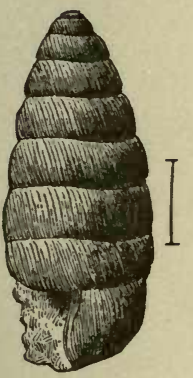

1.

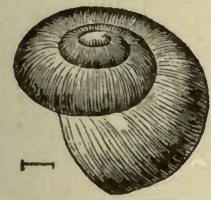

11.

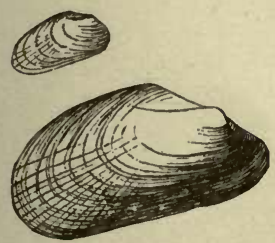

16.

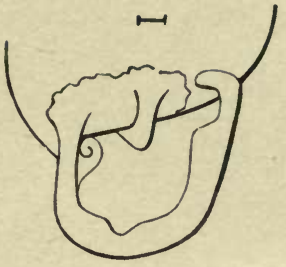

8.
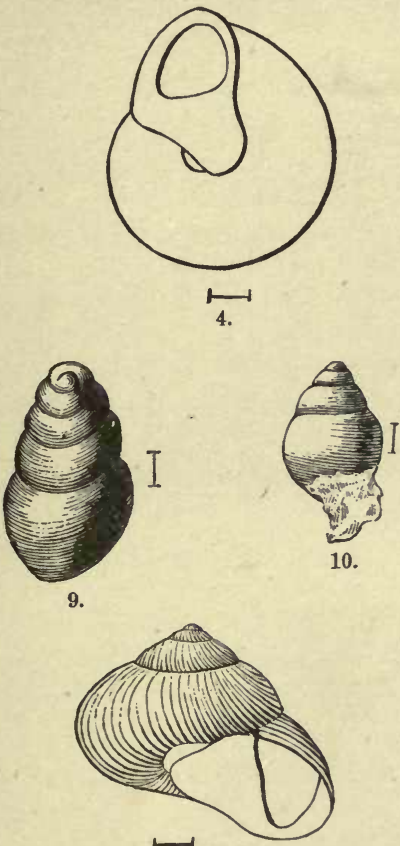

3.
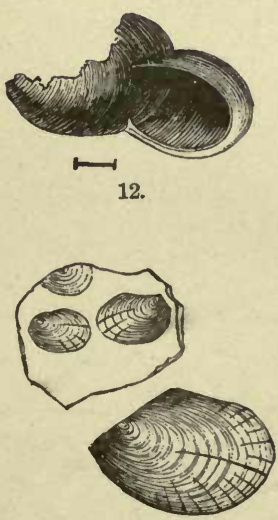

17.
ANNUAL REPORT $1882 \mathrm{Pl}$
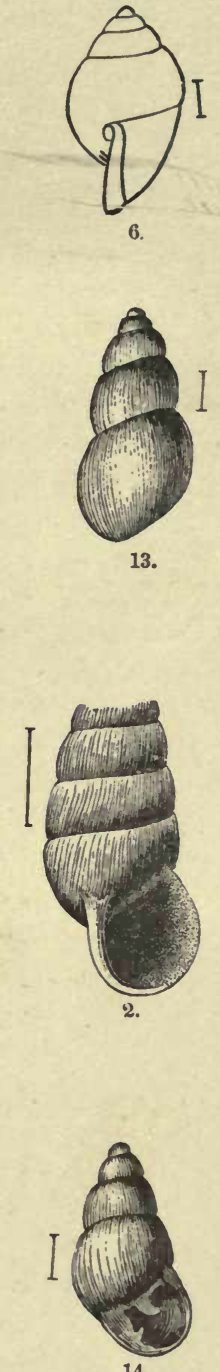

14.

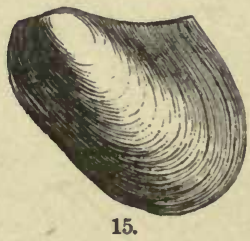

CARBONIFEROUS. 



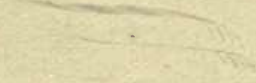

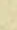




\section{PLATE 3. JURASSIC AND TRIASSIC ?}

Unio steward White. (Page 426.)

Fig. 1. Outline of a left valve restored from fragments, natural size.

Unio NuCalis Meek \& Hayden. (Page 426.)

Fig. 2. Lateral view of a left valve slightly restored from a specimen a little crushed.

Fig. 3. Dorsal view of the same; the right valve restored in symmetry with the left.

Fig. 4. Dorsal view of one of the originally figured types, slightly restored, the specimen being a little crushed; all natural size.

Unio CRistonensis Meek. (Page 425.)

FIG. 5. Right side view of Mr. Meek's most perfeet type, natural size.

Planoris veternus M. \& H. (Page 446.)

FIG. 6. Lateral view, natural size, and the same enlarged; also, a transverse section showing the number and shape of volutions. After Meek.

Valvata SCABRida M. \& H. (Page 470.)

Fig. 7. Copy of original figure of Meek \& Hayden.

Viviparus gillianus M. \& H. (Page 470.)

FiG. 8. Two views of the typo speeimen, natural size. After Meek \& Hayden.

Lioplacodes veternus M. \& H. (Page 4\%0.)

Fig. 9. Two views of the type specimen, natural size. After Meek \& Hayden.

Neritina nebrascensis M. \& H. (Page 457.)

Fig. 10. Two views of the type specimen, natural size. After Meek \& Hayden.

Fig. 11. Enlarged view of a portion of the surface showing the pattern of the color markings. 

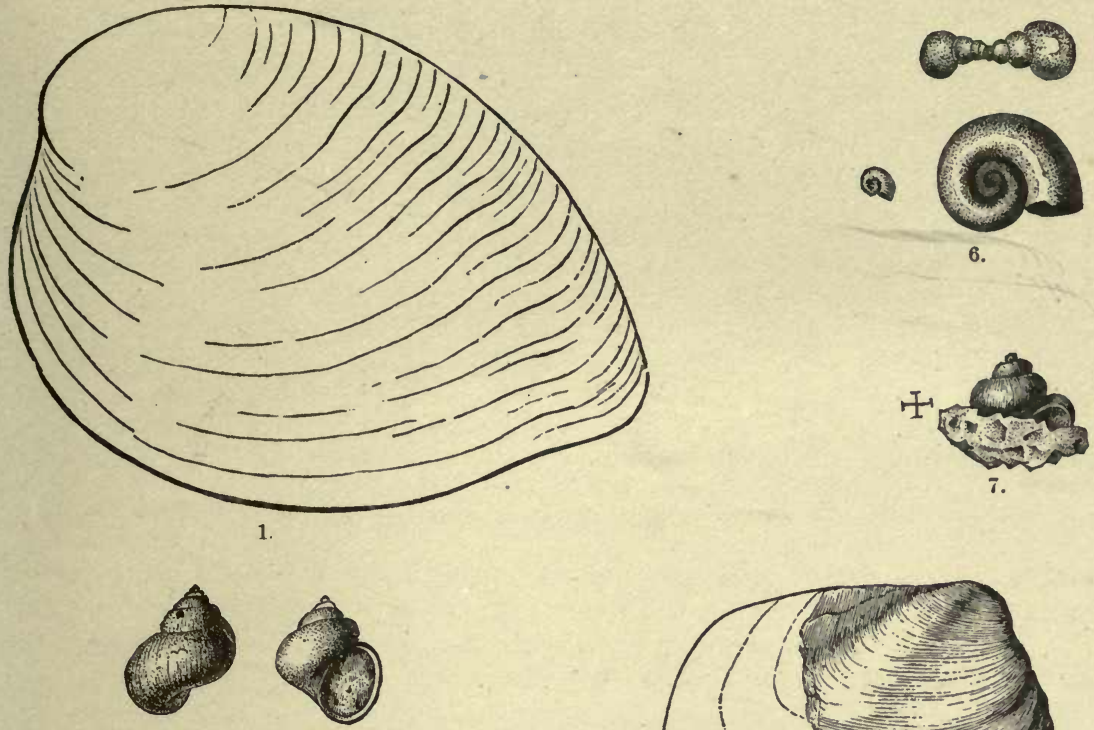

8.
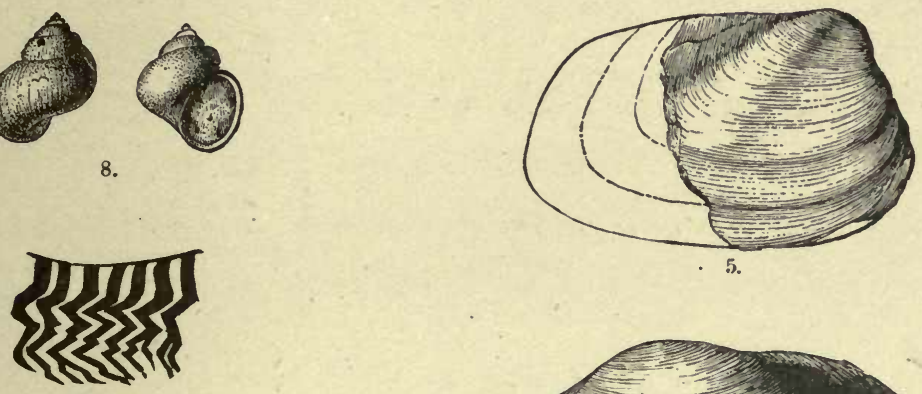

11.
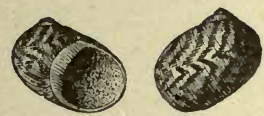

10.
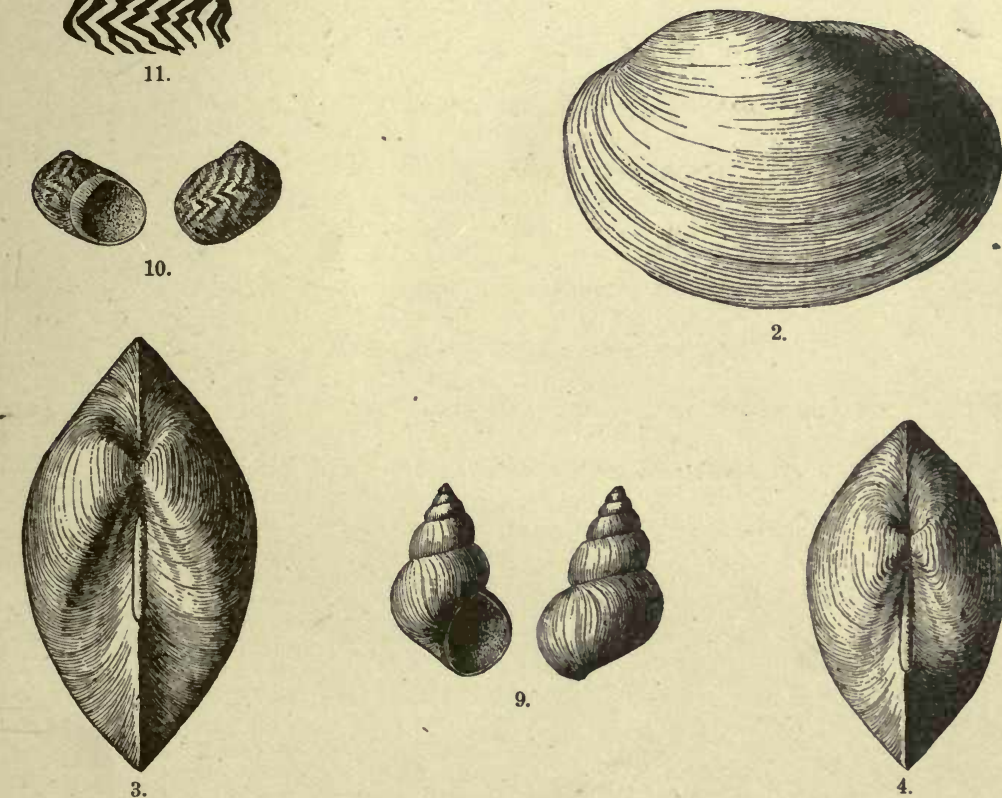

9.

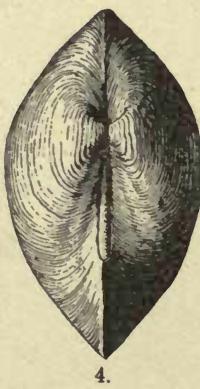

JURASSIC AND TRIASSIC ? 


PLATE 4. CRETACEOUS.

Margaritana nebrascensis Meek \& Hayden. (Page 427.)

Fig. 1. Left side view, natural size.

Fig. 2. Dorsal view of the same.

Cyrena dakotensis M. \& H. (Page 436.)

FIG. 3. Left side view, natural size.

Fig. 4. Dorsal view of the same. After Meek.

$$
\text { Physa — }
$$

Fig. 5. Lateral view of an imperfect natural cast, natural size. 
U. S. GEOLOGICAL SURVEY
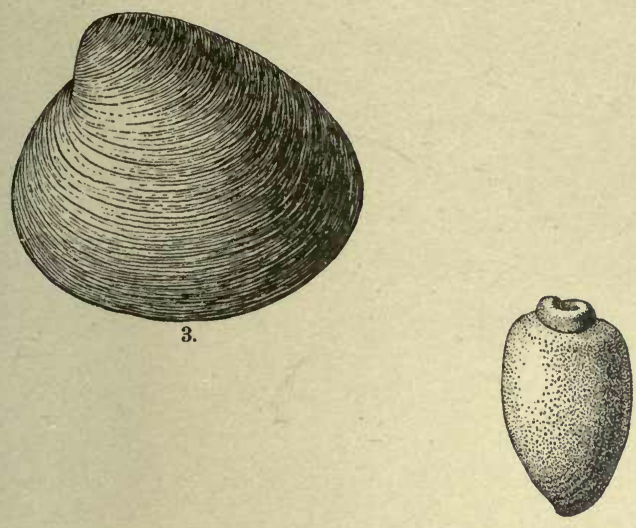

5.
ANNUAL REPORT $1882 \quad \mathrm{P}_{\mathrm{L}} 4$

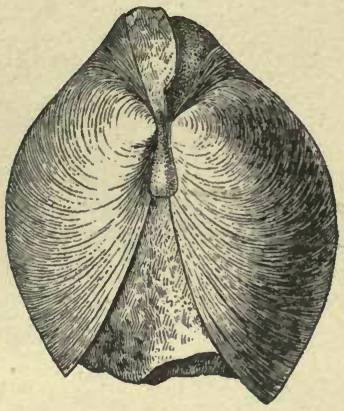

4.

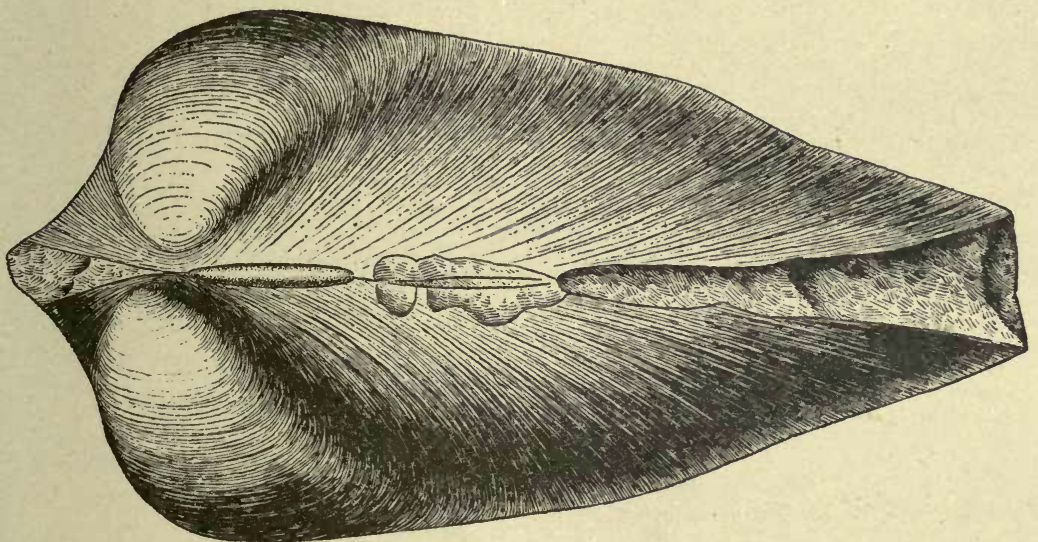

2.

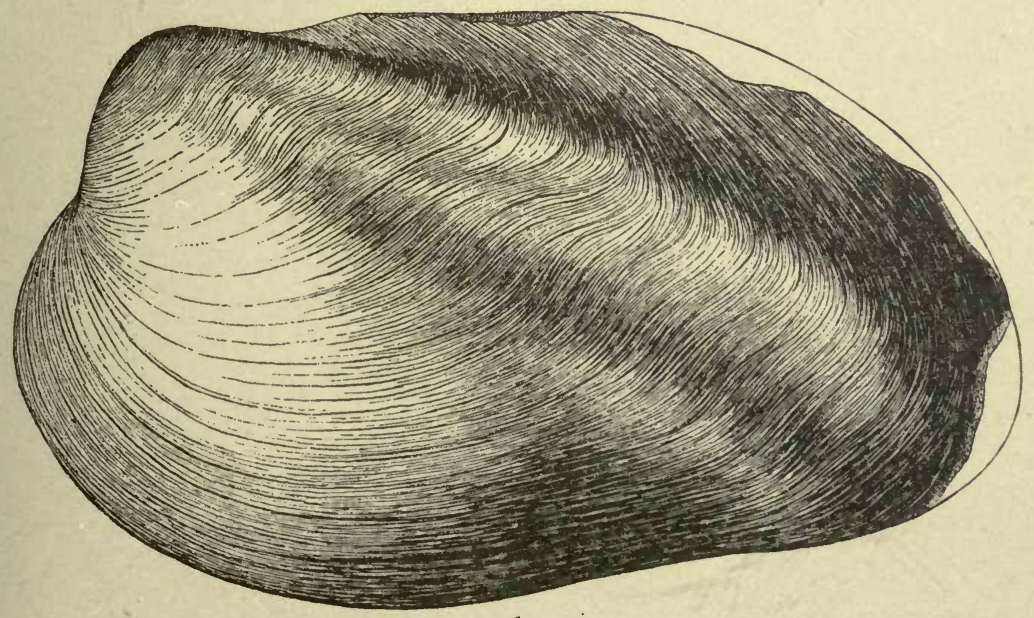

1.

CRETACEOUS. 

PLATE 5. CRETACEOUS.

Unio Penultimus Gabb. (Page 42\%.)

FIG. 1. Copy of Mr. Gabl's original figure, natural size.

Unio nubbardi G. (Page 427.)

FIG. 2. Left side view, natural size.

Frg. 3. Outline of front view. After Gabb.

Cxrena Carletoni Meek. (Page 436.)

Fig. 4. Left view, natural size.

Frg. 5. Dorsal view of the same.

Anomia propatoris White. (Pago 422.)

Frg. 6. Exterior view of an upper valve, natural size.

FrG. 7. Lateral view of the same.

\section{Neritiva (Velatella) bellatula M. (Page 458.)}

FIG. 8. Dorsal view of a small example, enlarged.

Fig. 9. Lateral view of another example, enlarged.

\section{Neritina (Velatella) Carditoides M. (Page 458.)}

Fig. 10. Dorsal view of the type specimen, natural size.

\section{Neritina Bannisteri M. (Page 458.)}

Fut. 11. Lateral view, enlarged, showing the color markings. The specimen has been a little compressed.

Fig. 12. Two views of a small example, enlarged. The color markings are not proserved in this example.

Melampus ? antiquUs M. (Page 444.)

Fig. 13. Lateral view of a small example, enlarged.

Frg. 14. Opposite view of the same.

Fig. 15. Fragment of a very large example, natural size.

FIG. 16. Apex very much enlarged, showing the reversed initial whorl.

$$
\text { Melampus: — (Page 444.). }
$$

Fig. 17. Lateral view, natural size.

Piysa carletoni M. (Page 449.)

Fig. 18. Lateral view, natural size.

Valvata nana M. (Page 470.)

Fig. 19. Lateral view, enlarged.

Fig. 20. Summit view of the same. 


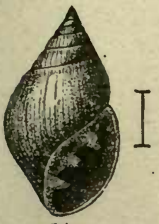

14.

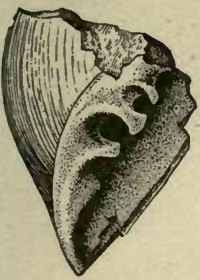

15.

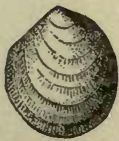

6.

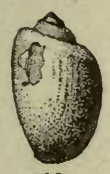

18.

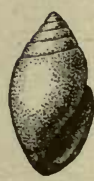

17.
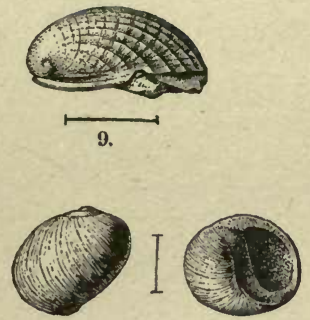

12.

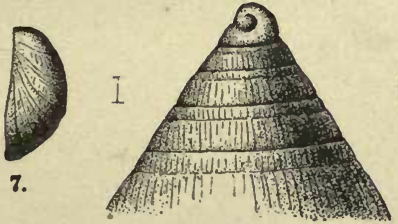

16.
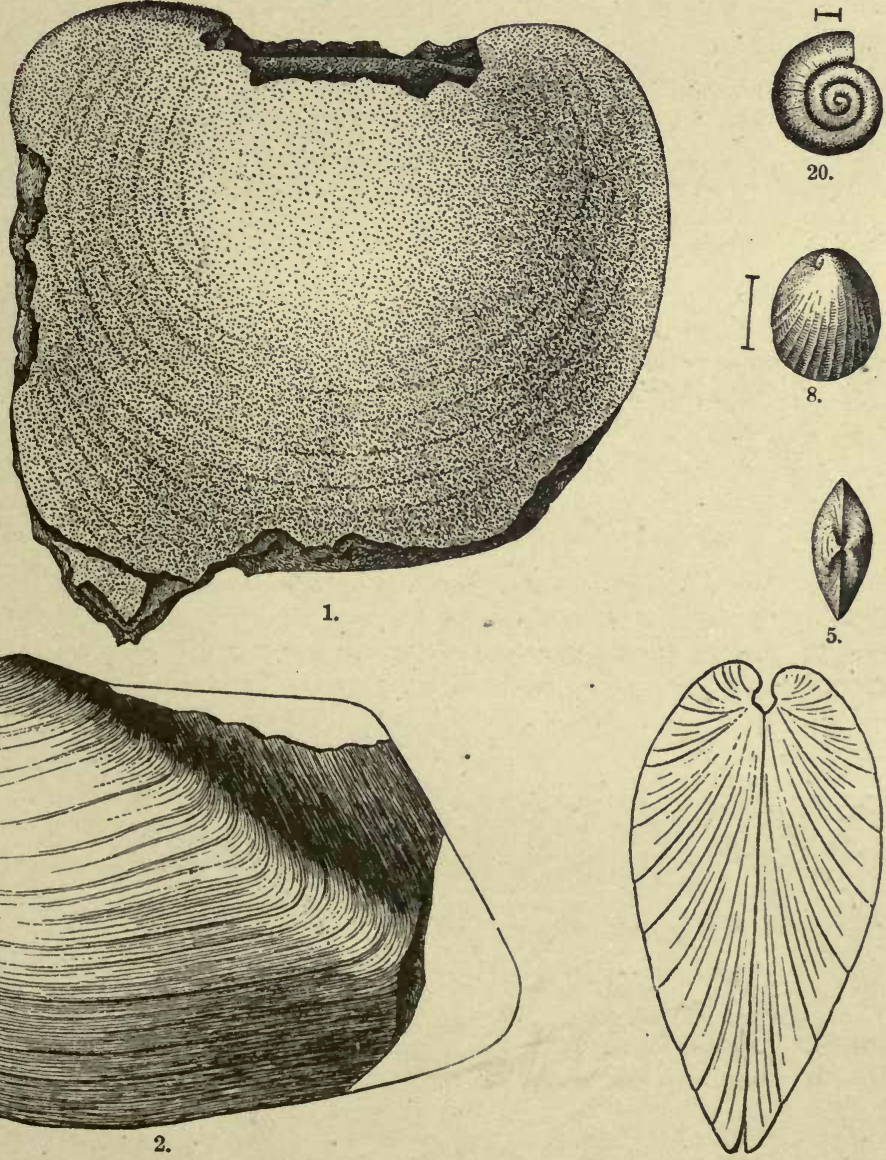

3.
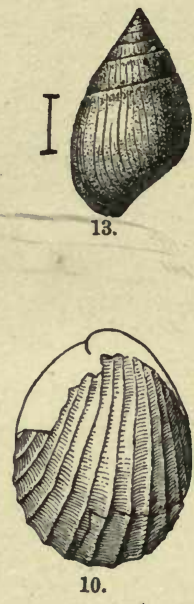

20.
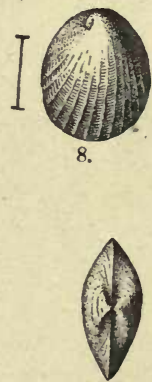
5.

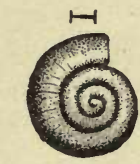

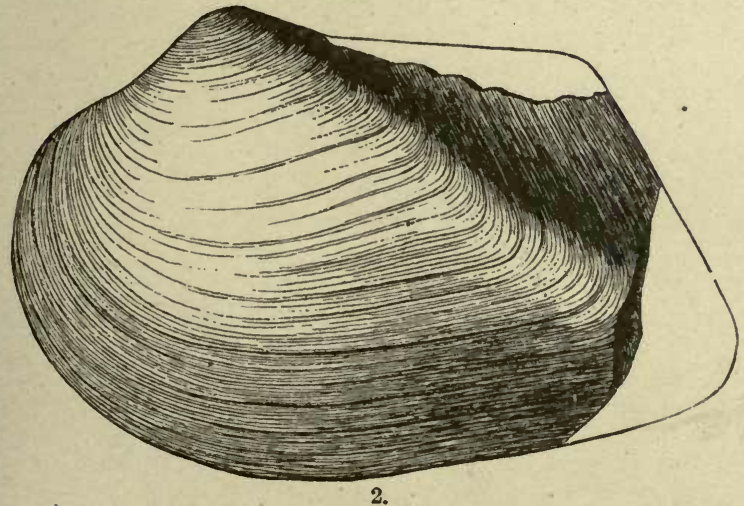

CRETACEOUS. 

PLATE 6. BEAR RIVER LARAMIE.

Unio beluiplicatos Meek. (Page 430.)

Fig. 1. Left side view, natural size.

FIG. 2. Similar view of another example.

FIG. 3. Dorsal view of a left valve, a little distorted, showing the plications of the umbo.

\section{Pyrgulifera humerosa M. (Page 460.)}

Frg. 4. Lateral view of a large example, natural size.

FIG. 5. Opposite view of the same. This is the same example that is figured by Meek on p. 177 U. S. Geol. Sur. 40th Parallel, vol. iv, but it has since been cleaned of extraneous matter.

Frg. 6. Lateral view of a smaller example.

\section{Goniobasis cleburni White. (Page 462.)}

Frg. 7. Lateral viow, natural size.

FIG. 8. Similar view of another example.

FIG. 9. Fragment of a large example.

Goniobasis chieysalloidea W. (Page 462.)

Fig. 10. Lateral view, natural size.

FIG. 11. Similar view of another example.

Goniobasis macilenta W. (Page 462.)

Fig. 12. Lateral view, enlarged.

\section{Goniobasis chrysalis M. (Page 462.)}

FıG. 13. Lateral view, enlarged.

FIG. 14. Similar view of another example.

Limnate (Limnophysa) nitidula M. (Page 445.)

Frg. 15. Lateral view, enlarged two diameters.

FIG. 16. Opposite view of the same.

$$
\text { Pнysa - (Page 449.) }
$$

FiG 17. Lateral view, natural size.

Limnaea (Acella) haldemani W. (Page 445.)

FIG. 18. Lateral view, enlarged.

Frg. 19. Opposite view of the same. 


\section{U. S. GEOLOGICAL SURVEY}

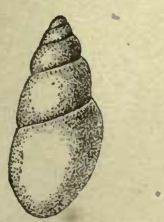

15.

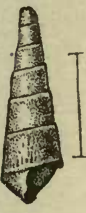

12.

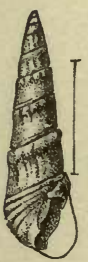

13.

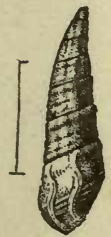

1.4.

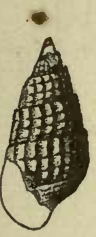

11.

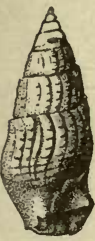

10.

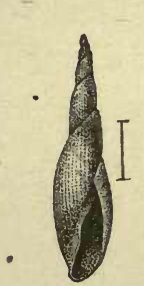

19.
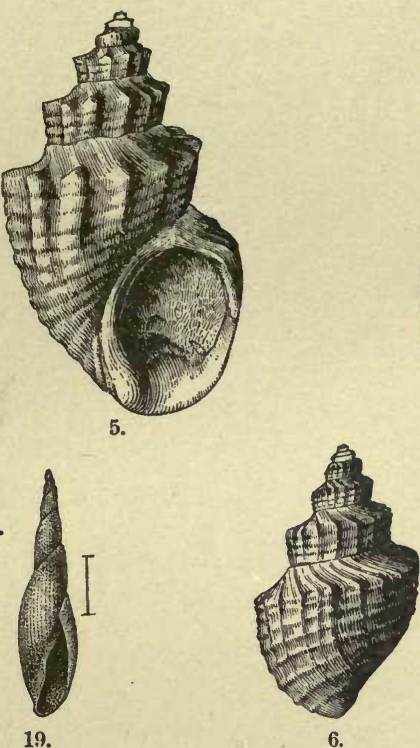

ANNUAL REPORT 1882 Pl.6
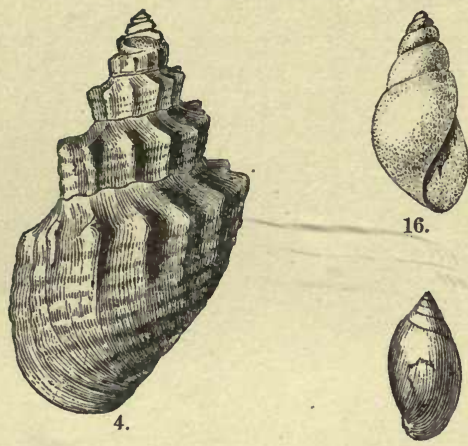

17.

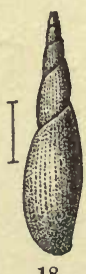

18.

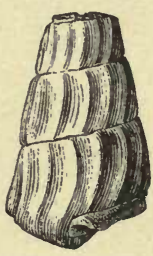

9.

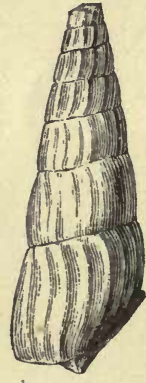

8.

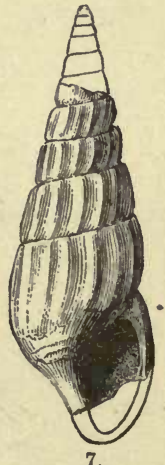

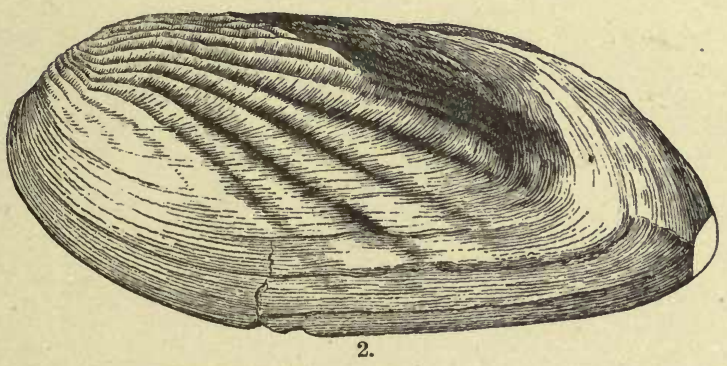

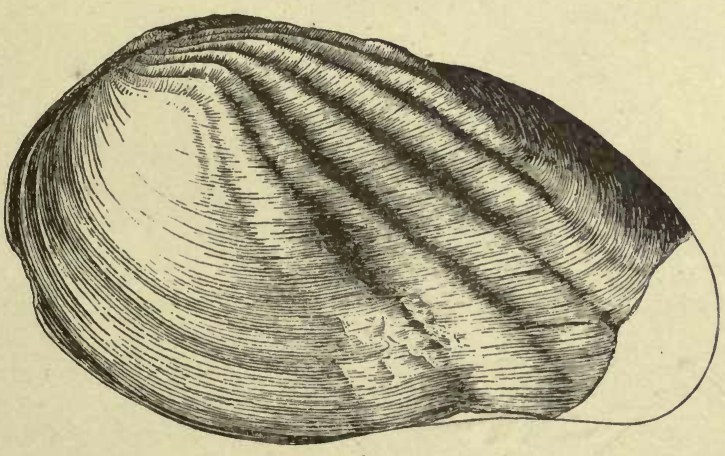

1.

BEAR RIVER LARAMIE. 

$-$

c

단 


\section{PLATE 7. BEAR RIVER LARAMIE.}

UNIO vetustus Meek. (Page 430.)

FIG. 1. Left side view of a large example; a little compressed laterally.

FrG. 2. Right side view; the posterior portion a little compressed vertically.

FIG. 3. Dorsal view of Fig. 2; the left valve restored in symmetry with the right.

FIg. 4. Interior view of a left valve.

(All natural size.)

\section{Neritina Natrciformis White. (Page 458.)}

Fig. 5. Lateral view; enlarged.

Frg. 6. Opposite view of the same.

Goniobasis endlichi W. (Page 463.)

FIG. 7. Lateral view; revolving lines faint.

Fig. 8. Another example; revolving lines obsolete.

Frg. 9. Apical portion of another example; revolving lines unusually distinct. (All natural size.) 

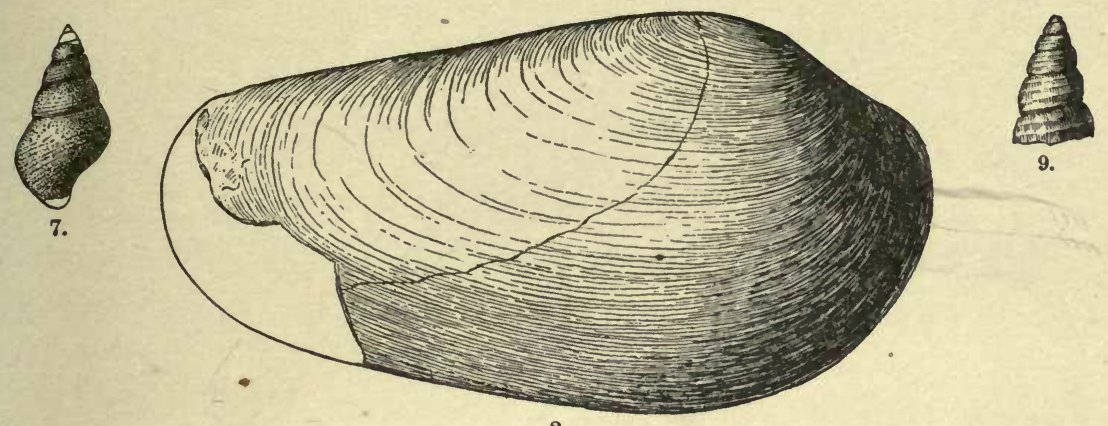

9.
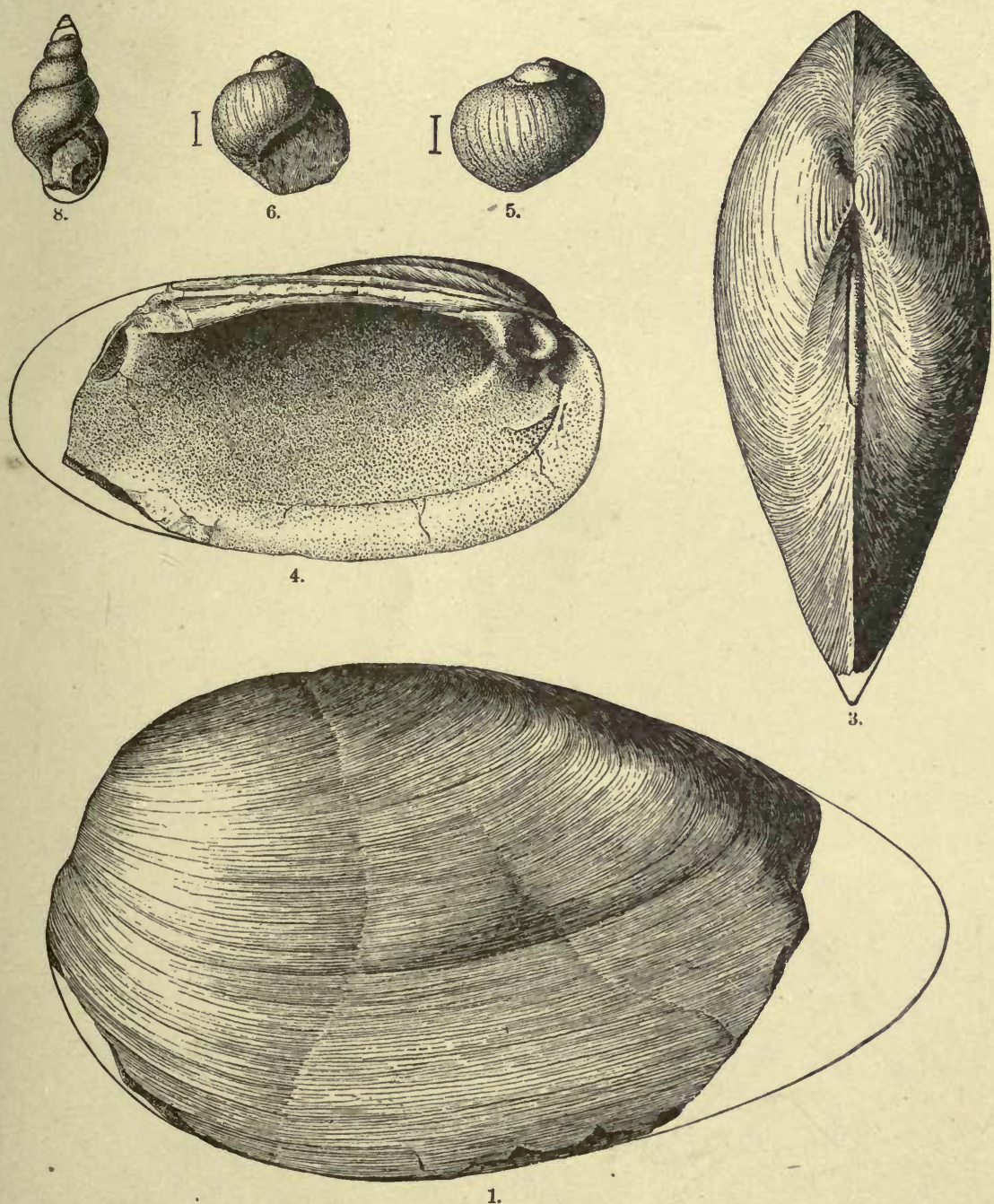

BEAR RIVER LARAMIE. 

PLATE 8. BEAR RIVER LARAMIE.

Viviparus couesir White. (Page 467.)

Fig. 1. Lateral view of a very large example, natural size.

\section{RHYTophorus priscus Meek. (Page 444.)}

FG. 2. Lateral view, natural size.

FrG. 3. Opposite view of the same. After Meek.

\section{RHYTophonUS MEeKII W. (Page 444.)}

Fig. 4. Lateral view, natural size.

FIG. 5. Opposite view of a larger example.

Campeloma macrospira M. (Page 469.)

Fig. 6. Lateral view, natural size.

Fig. 7. Opposite view of the same.

Corbicula (Veloritina) durkeei M. (Page 437.)

Fig. 8. Left valve.

FIG. 9. Similar view of another example.

Fig. 10. Dorsal view of another example.

Fig. 11. Front view.

(All natural size.)

Corbula pyiriformis M. (Page 441.)

Fra. 12. Right side view.

Fig. 13. Dorsal view of the same.

Fig. 14. Front view of the same.

Fig. 15. Interior view of a right valve.

FIG. 16. Interior view of a left valve.

(All natural size.) 
U. S. GEOLOGICAL SURVEY

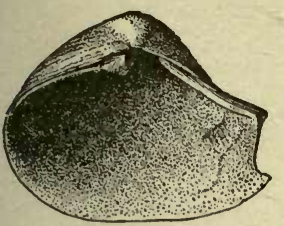

15.
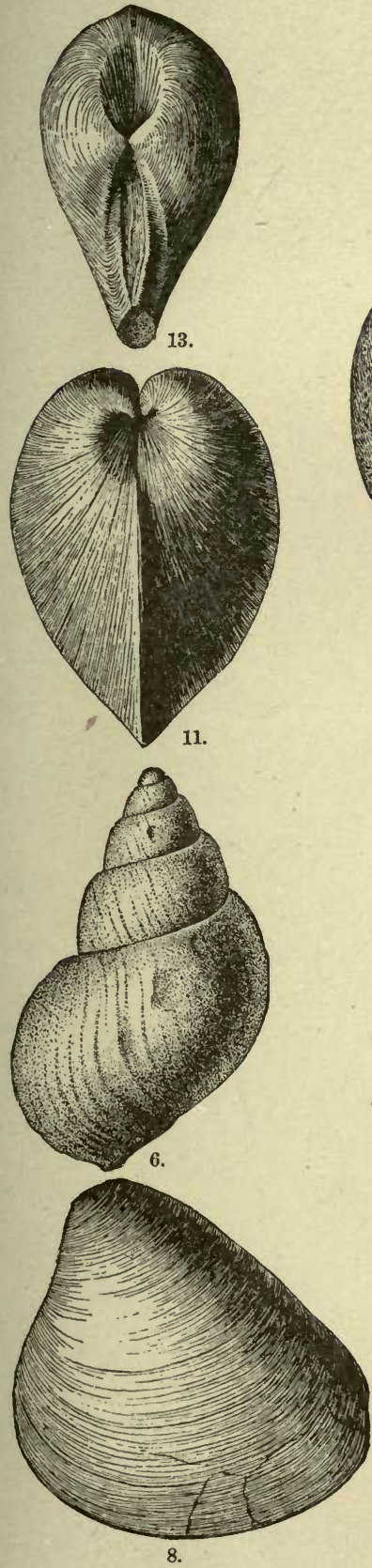
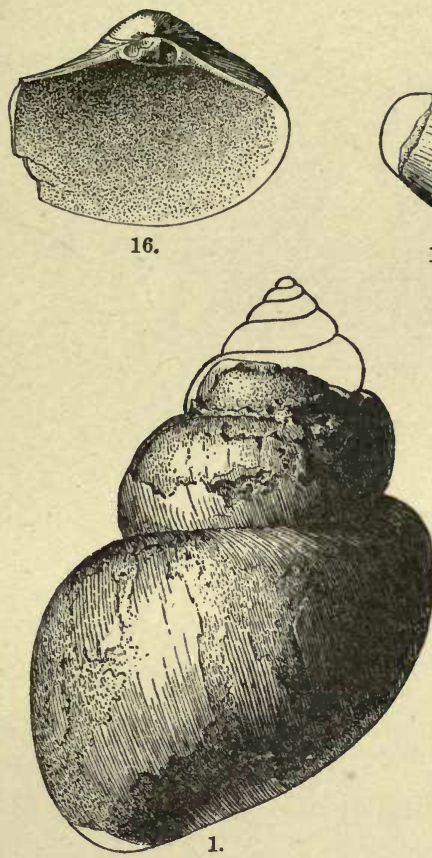

12.
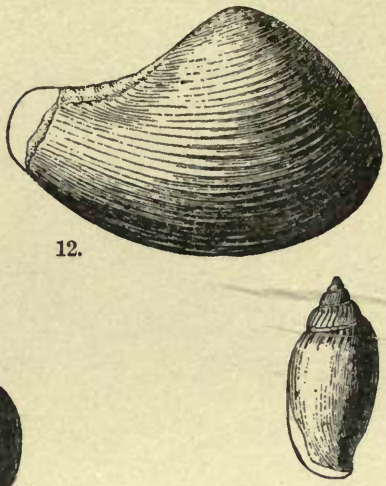

4.

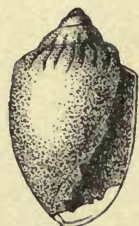

3.

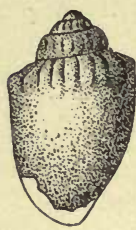

2.

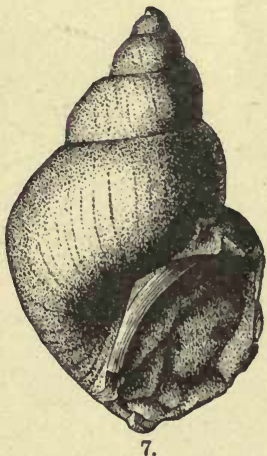

7.

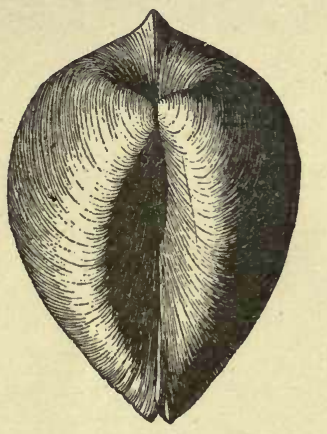

10.

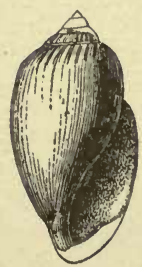

5.

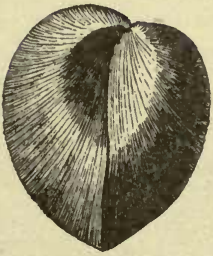

14.

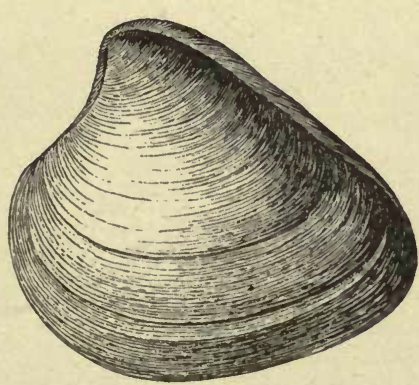

BEAR RIVER LARAMIE. 



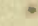

..

•

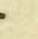

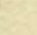


PLATE 9. LARAMIE.

Ostrea Glabra Meek \& Hayden.- (Page 421.)

Frg. 1. Exterior view of type; lower valve. After Meek.

FIG. 2. Interior view of the same.

Fig. 3. Exterior view of a lower valve, from the valley of the South Platte, Colorado.

Fra. 4. Interior view of the same.

(All natural size.) 

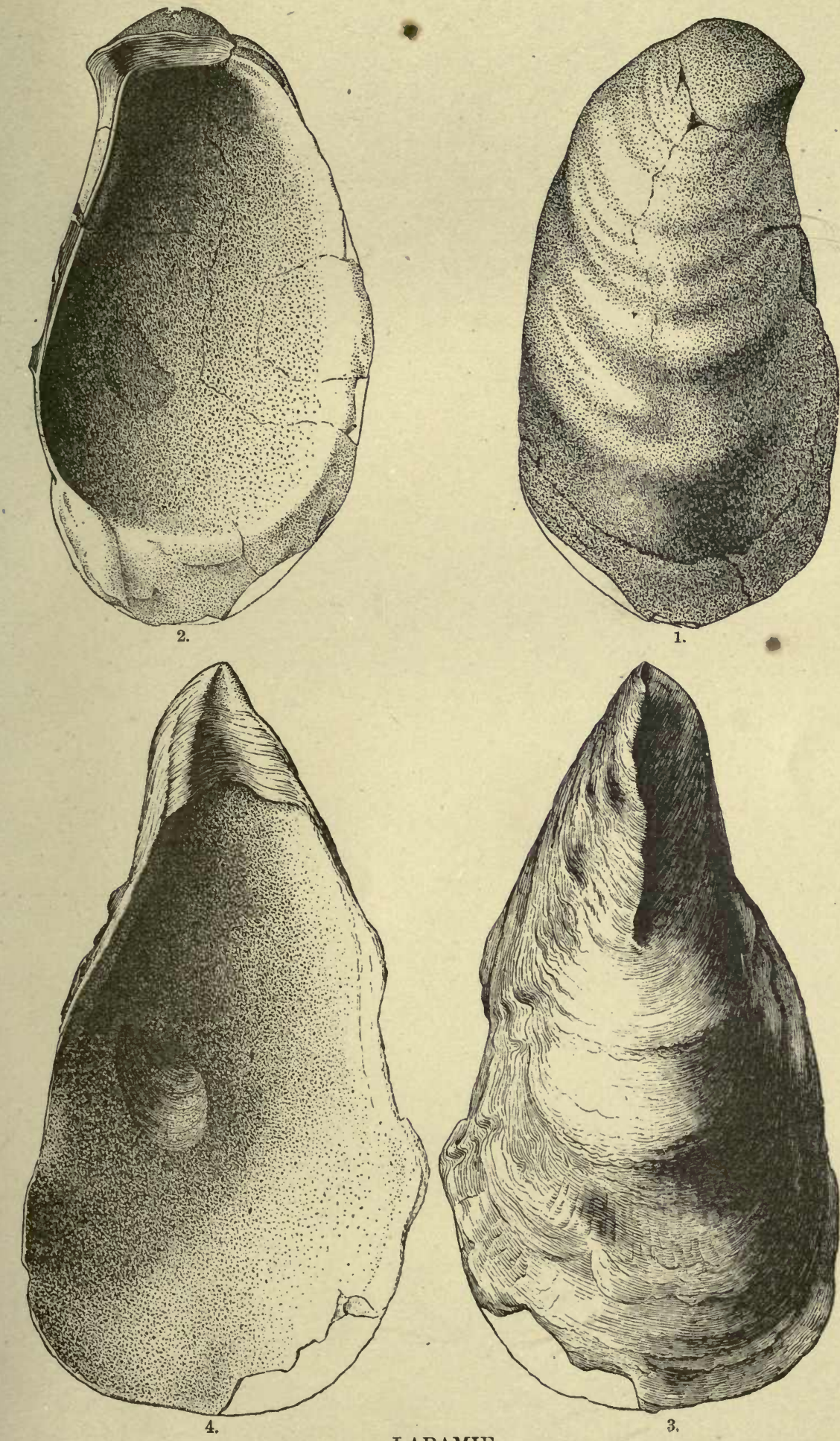

LARAMIE. 

PLATE 10. LARAMIE.

Ostrea glabra Moek \& Hayden. (Page 421.)

Fig. 1. Exterior view of an upper valve, from the valley of the South Platte, Colorado. Fig. 2. Interior view of the same.

FIG. 3. Lower valve of the type of the variety 0 . insecuris White; exterior view. Fig. 4. Interior view of the same.

Fig. 5. Type specimen of variety 0 . arcuatilis Meek.

(All natural size.) 
U. S. GEOLOGICAL SURVEY

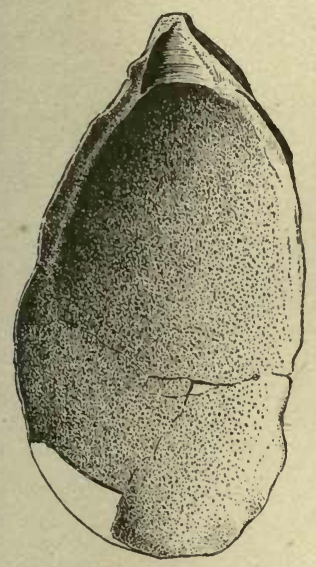

4.

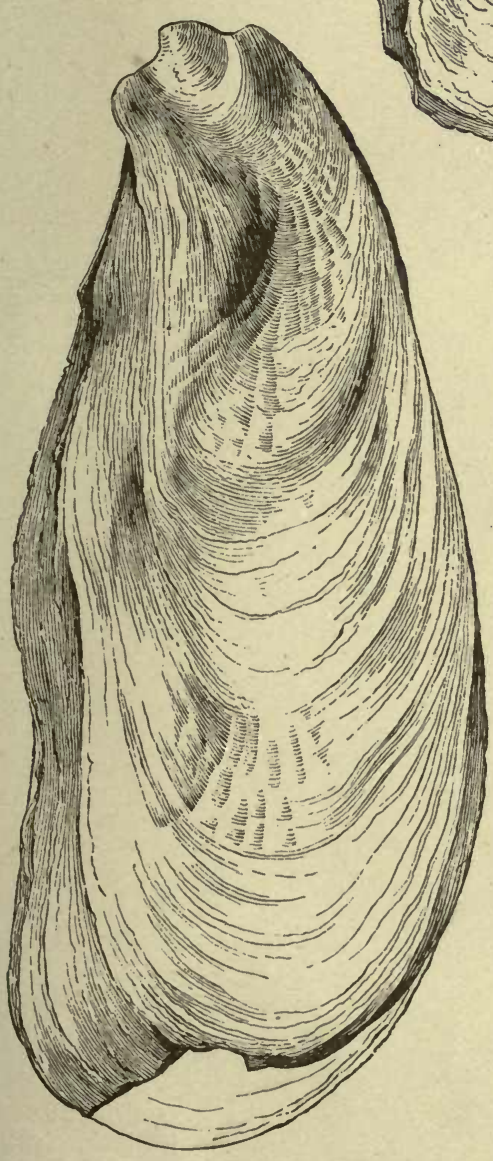

1.
ANNUAL REPORT $1882 \quad \mathrm{Pl}, 10$
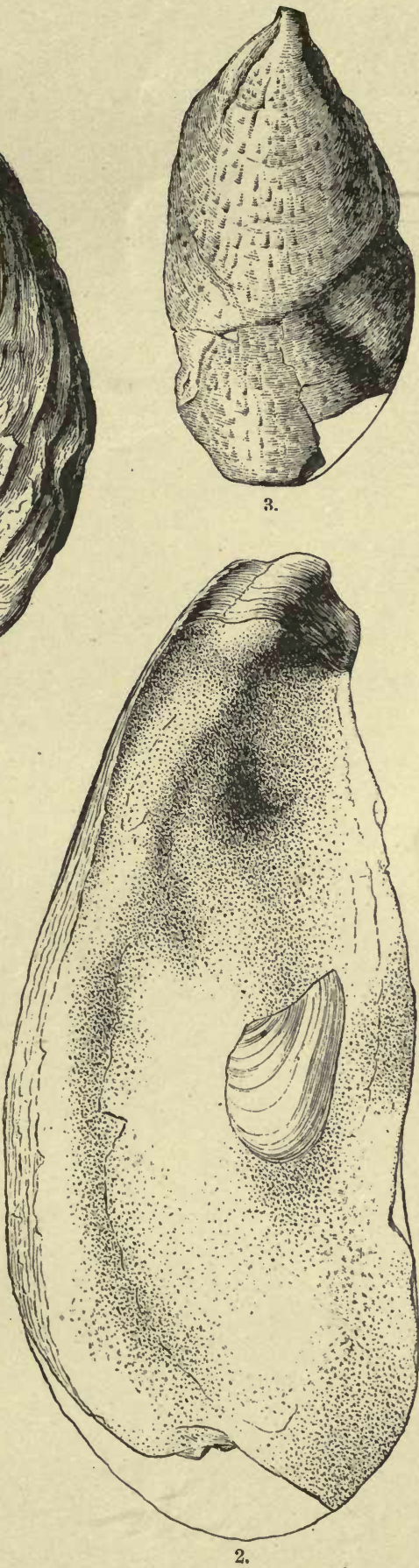

LARAMIE. 

PLATE 11. LARAMIE.

Ostrea Glabra Meek \& Hayden. (Page 421.)

FIG. 1. Exterior view of an upper valve of the variety 0 . vyomingensis Meek, from the valley of the South Platte, Colorado.

Fig. 2. Interior view of the same.

FIG. 3. Exterior view of an example of the upper valve of the same variety, from Point of Rocks, Southern Wyoming.

FIG. 4. Interior view of the same.

(Anl natural size.) 


$$
\begin{aligned}
& 81 \\
& 09
\end{aligned}
$$






\section{PLATE 12. LARAMIE.}

Ostrea Glabra Meek \& Hayden. (Page 421.)

FIG. 1. Interior view of an under valve of the variety 0 . wyomingensis Meek; from Point of Rocks, Southern Wyoming. Natural size.

Ostrea subtrigonalis Evans \& Shumard. (Page 421.)

Fig. 2. Exterior view of a lower valve.

Fig. 3. Interior view of another example of the lower valve.

Fig. 4. Exterior view of an upper valve.

FIG. 5. Interior view of the same.

(All natural size.)

\section{ANomia micronena Meek. (Page 422.)}

FIG. 6. Exterior view of an upper valve, showing radiating lines of ordinary character.

Frg. 7. Similar view of another example, the lines upon which are very fine, and less conspicuous than they appear upon the figure.

FrG. 8. Similar view of another example, having radiating lines much coarser than usual.

FIG. 9. Interior view of a large, nearly flat, upper valve, showing the four muscular scars, and the process beneath the beak.

FIG. 10. Similar view of another example, showing the process more plainly; but the scars are obliterated.

Frg. 11. Interior view, showing the under valve, with its byssal plug. (All natural size.)

\section{ANOMLA GRYPHORHYNCHUS M. (Page 422.)}

Frg. 12. Exterior view of a lower valve.

Fig. 13. Similar view of two other valves.

Fig. 14. Lateral view of Fig. 12.

Fig. 15. Interior view of an upper valve, showing the muscular markings and the small process beneath the beak. (All natural sizo.) 
U. S. GEOLOGICAL SURVEY
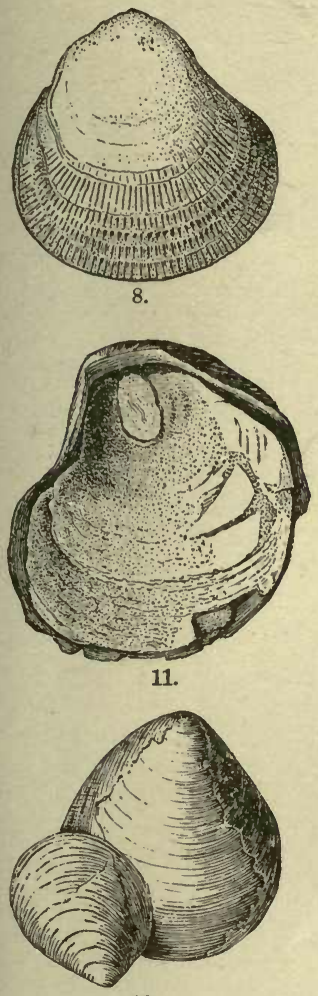

13.

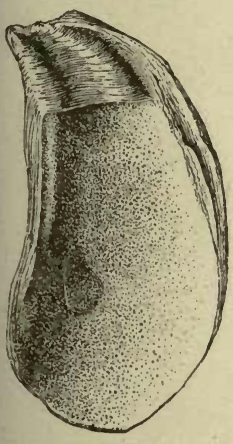

3.

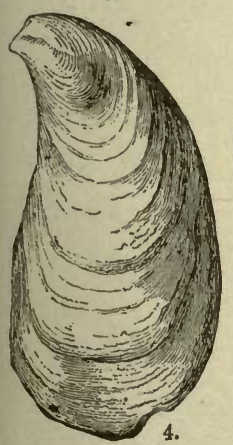

4.
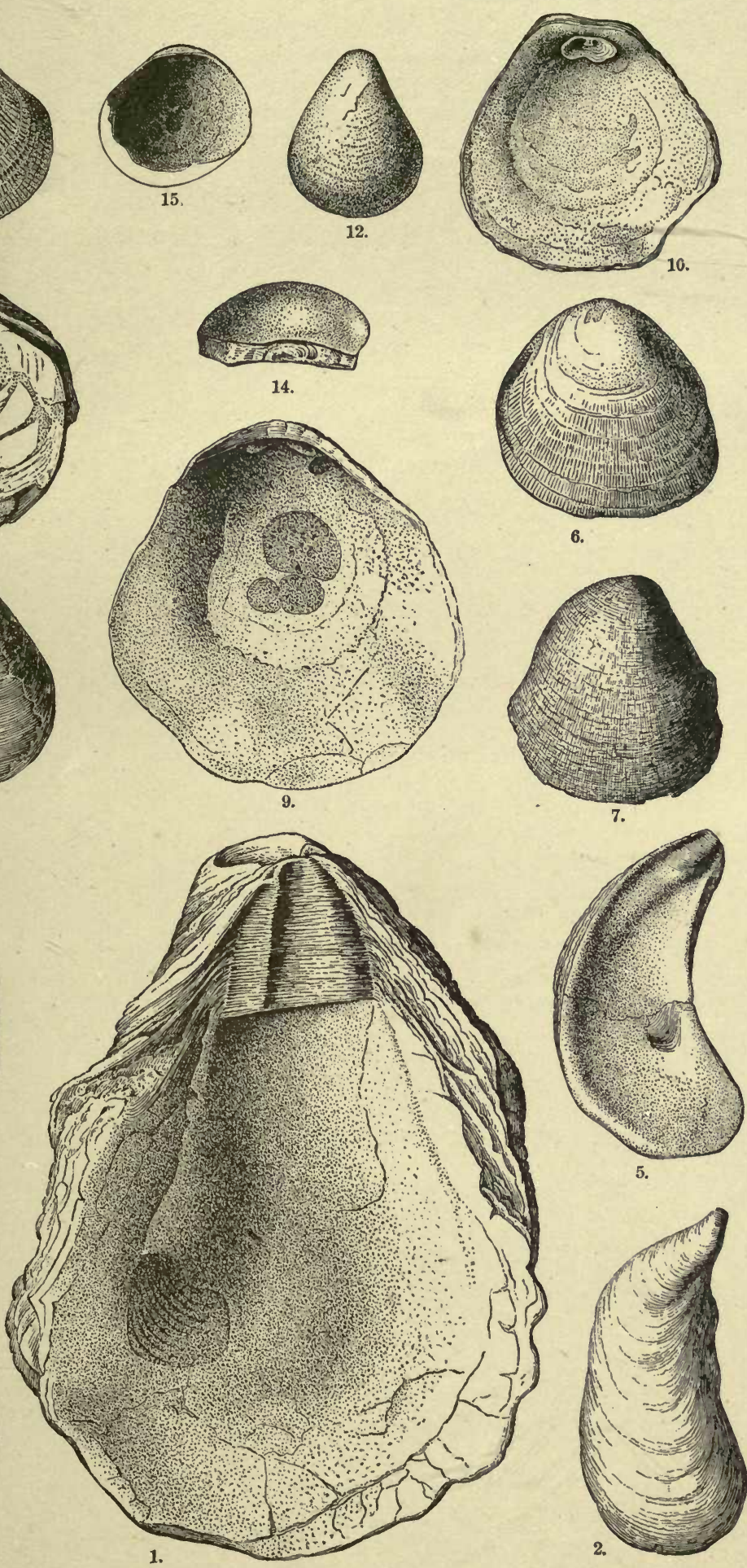

1.

LARAMIE. 



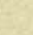
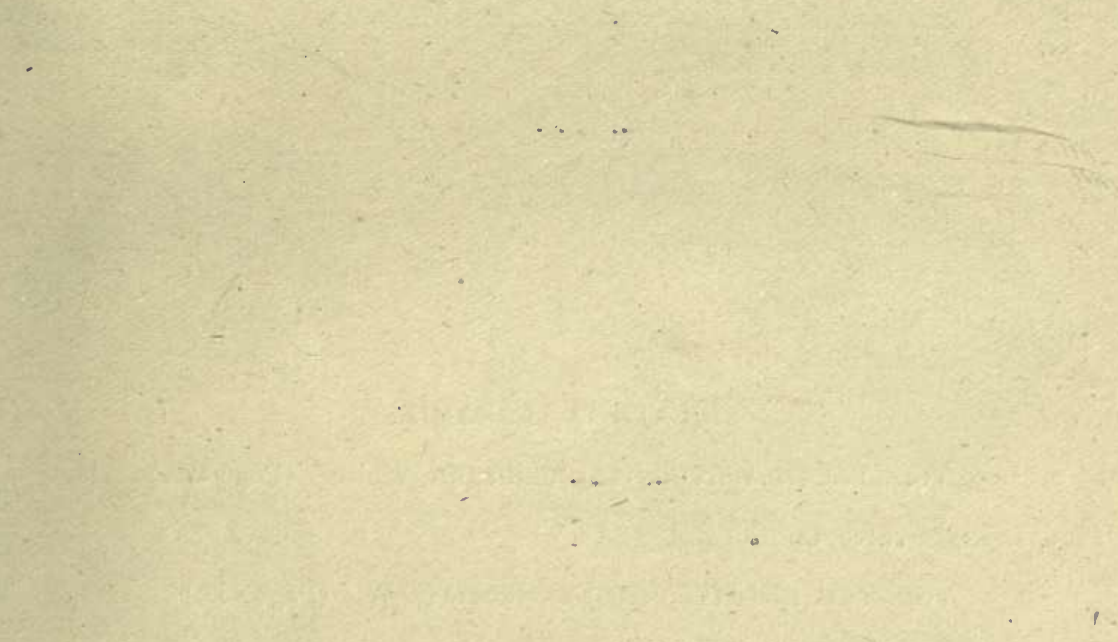

\section{.}

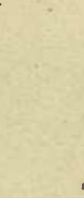

-. 
PLATE 13. LARAMIE.

VolseLLA (BRACHYDONTES) REgULARIS White. (Page 423.)

Fra. 1. Right valve, natural size.

Volsella (Brachydontes) laticostata W. (Page 423.)

Frg. 2. Right valve, natural size.

\section{Unio proavitus W. (Page 433.)}

Fig. 3. Left valve, exterior view.

FIG. 4. Similar view of right valve.

Fig. 5. Front view of another example.

FIG. 6. Interior view of a left valve.

(All natural size.)

UnIo GoINONOTUS W. (Page 433.)

FIG. 7. Right side view.

FIG. 8. Front view of another example.

FIG. 9. Left side view of young example.

Frg. 10. Dorsal view of the same.

(All natural size.) 
U. S. GEOLOGICAL SURVEY

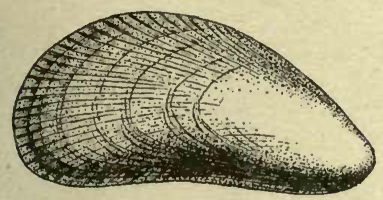

1.

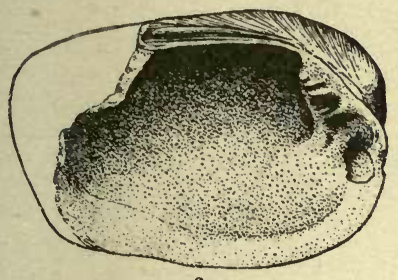

6.

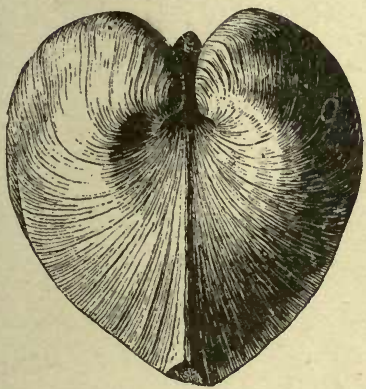

5.

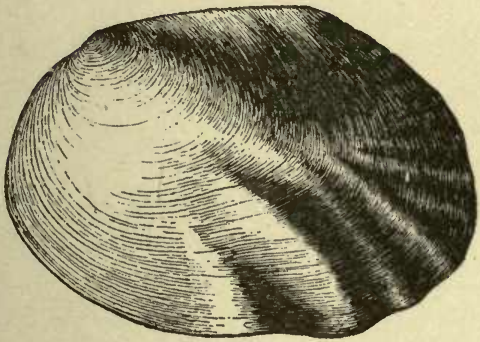

9.

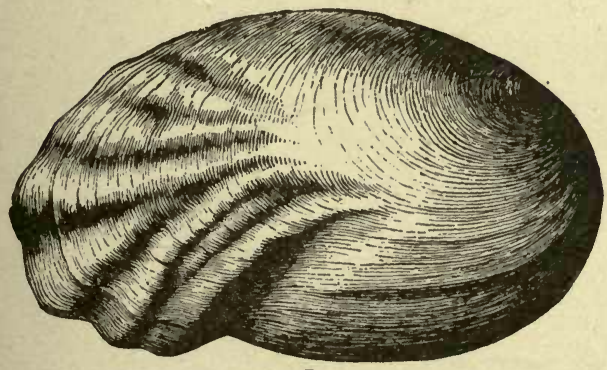

7.
ANNUAL REPORT 1882 Pl. 13

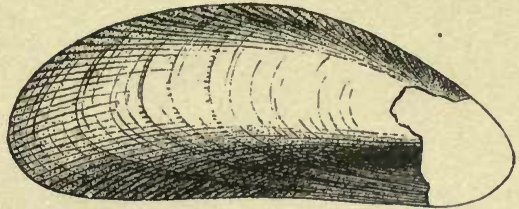

2.

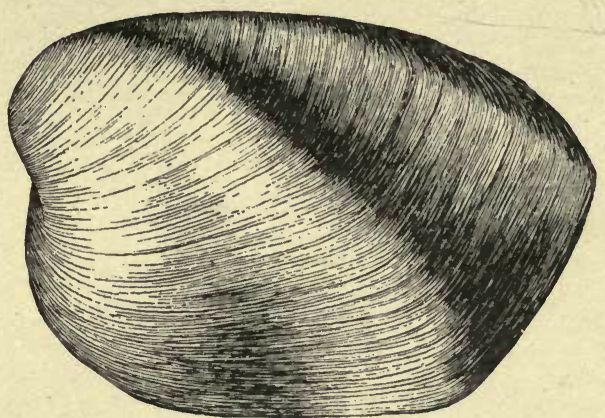

3.

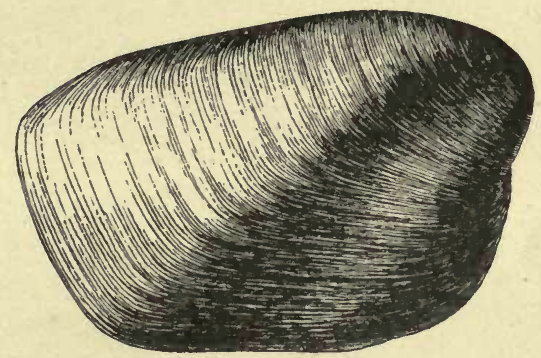

4.

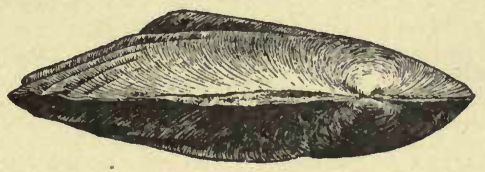

10.

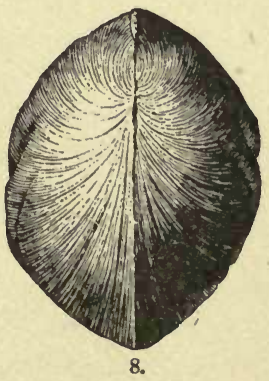

LARAMIE. 

D

2

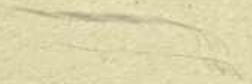


PLATE 14. LARAMIE.

Unio Priscus Meck \& Hayden. (Page 432.)

Fra. 1. Copy of the original figure of Meek \& Hayden.

Unio subspatulatus Meek. (Page 431.)

Fra. 2. Left side view.

Fig. 3. Dorsal view of the same. After Meek.

Unio primavus White. (Page 432.) -

Fig. 4. Exterior view of a small left valve.

Fig. 5. Interior view of a large right valve.

(Both natural size.)

Unio CRYptorirncius W. (Page 431.)

FrG. 6. Exterior view of an imperfect right valve.

FrG. 7. Interior view of a fragment of a left valve, showing the cavity behind the cardinal plate. 
U. S. GEOLOGICAL SURVEY

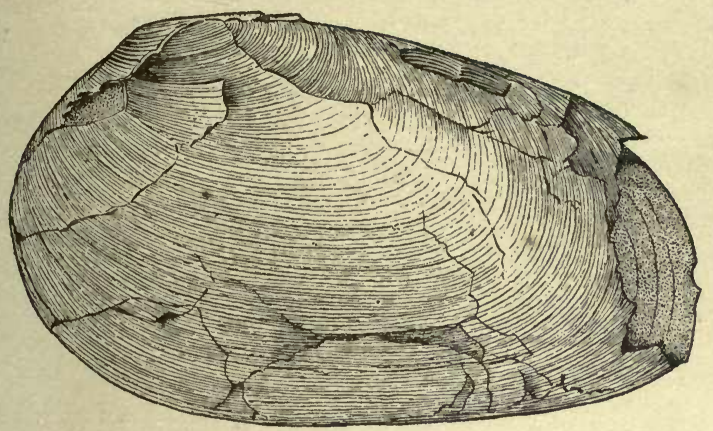

1.

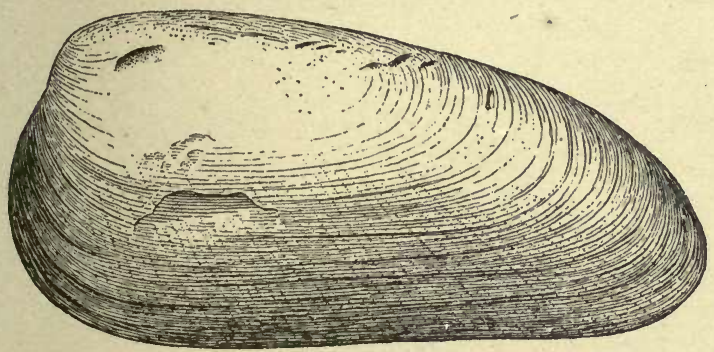

3.
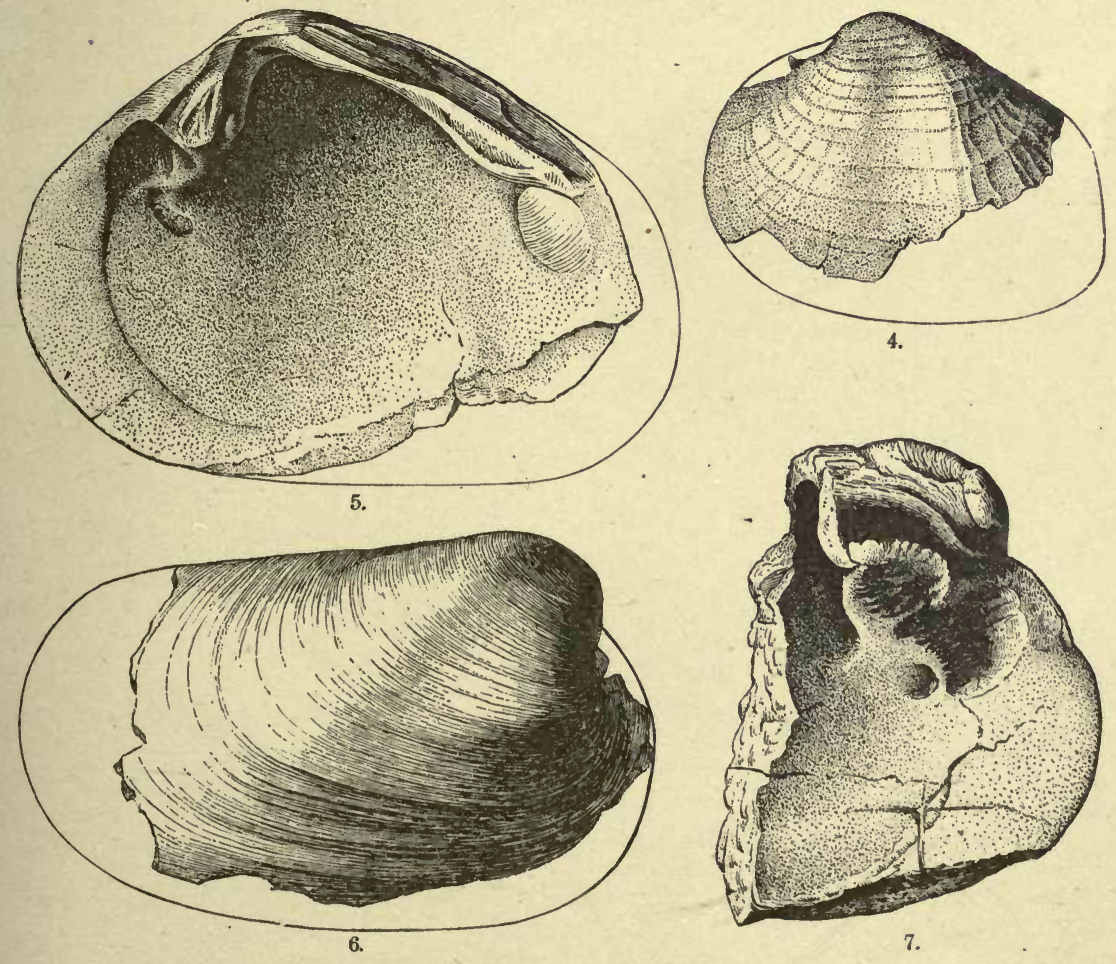

LARAMIE.
ANNUAL REPORT $1882 \quad \mathrm{Pl} .14$

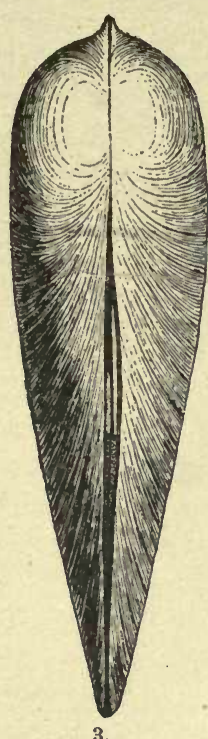

3.

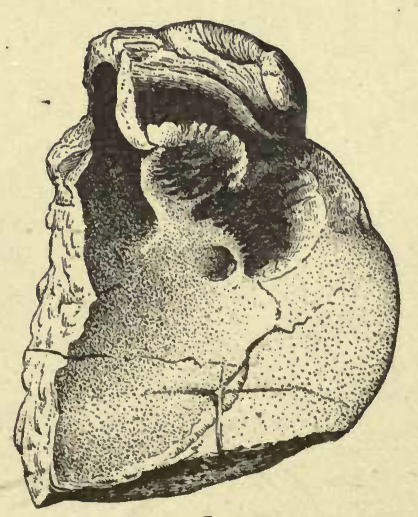

7. 


PLATE 15. LARAMIE.

UnIo ENDLICII White. (Page 432.)

Fig. 1. Right valve of a large example, exterior view.

FIG. 2. Interior view of a smaller left valve.

(Both natural size.)

UnIO PROPHeticus W. (Page 433.)

Fra. 3. Exterior view of a left valve. Natural size.

FIG. 4. Left side view.

Unio aLdRICHI W. (Page 433.)

Fig. 5. Dorsal view of the same. Natural size. 

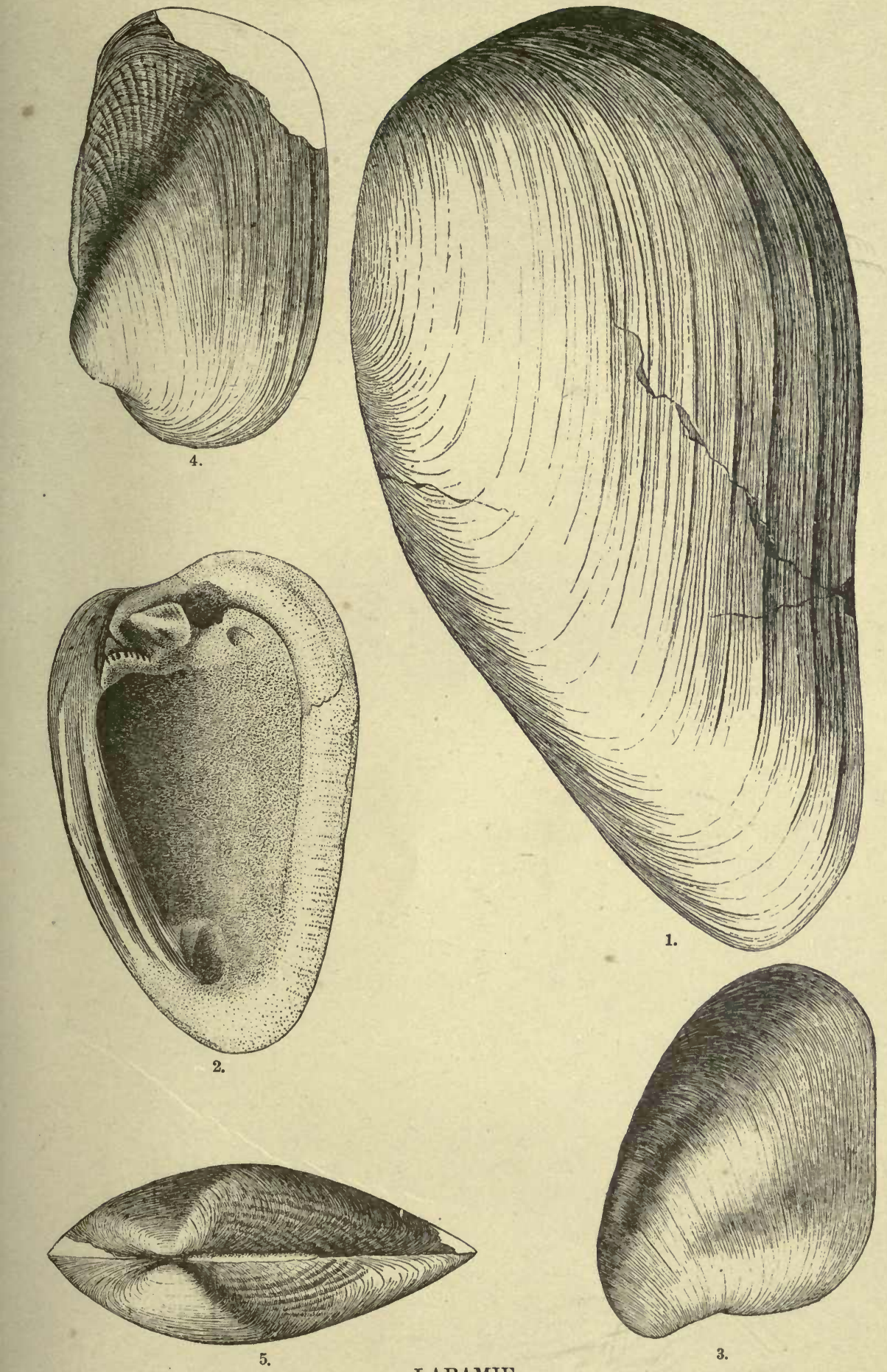

LARAMIE.

3. 


PLATE 16. LARAMIE.

Unio covesII White. (Page 432.)

Fig. 1. Exterior view of a left valve. Natural size.

Unio molmasianus W. (Page 433.)

Fig. 2. Left side view of an adult example.

Fig. 3. Dorsal view of the same.

Fig. 4. Left side view of a young example.

Fig. 5. Front view of the same.

Fig. 6. Posterior view of the same.

(All natural size.)

UNIO BRACIIYOPISTIIUS W. (Page 433.)

Fig. 7. Right side view of an example not fully adult.

Fig. 8. Front view of the same. Natural size. 
U. S. GEOLOGICAL SURVEY
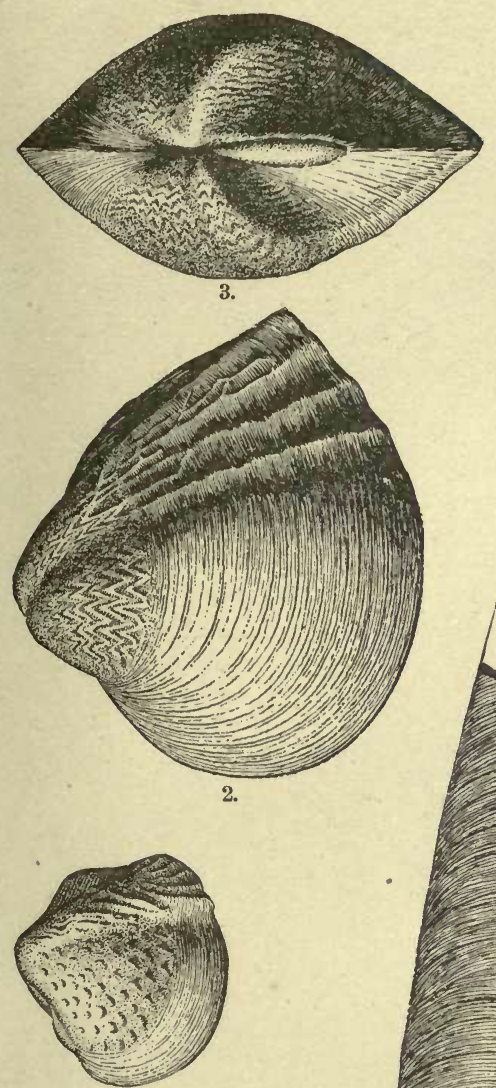

4.

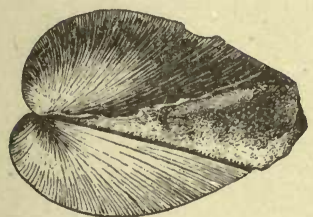

1.
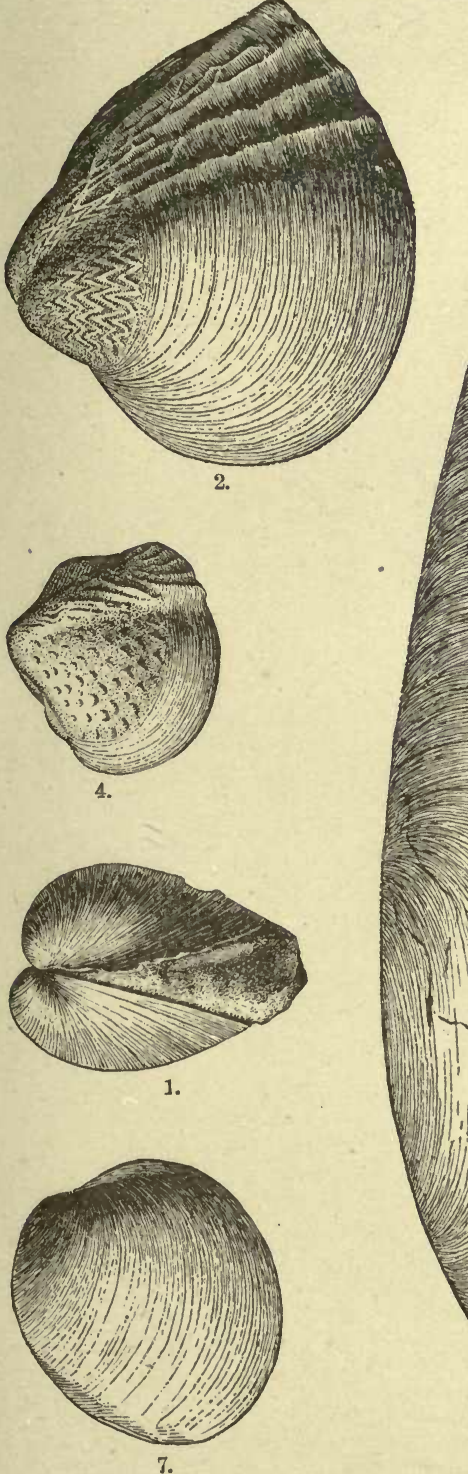

ANNUAL REPORT 1882 Pl. 16
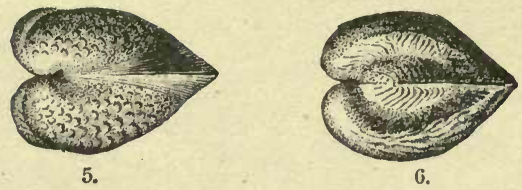

5.

6.
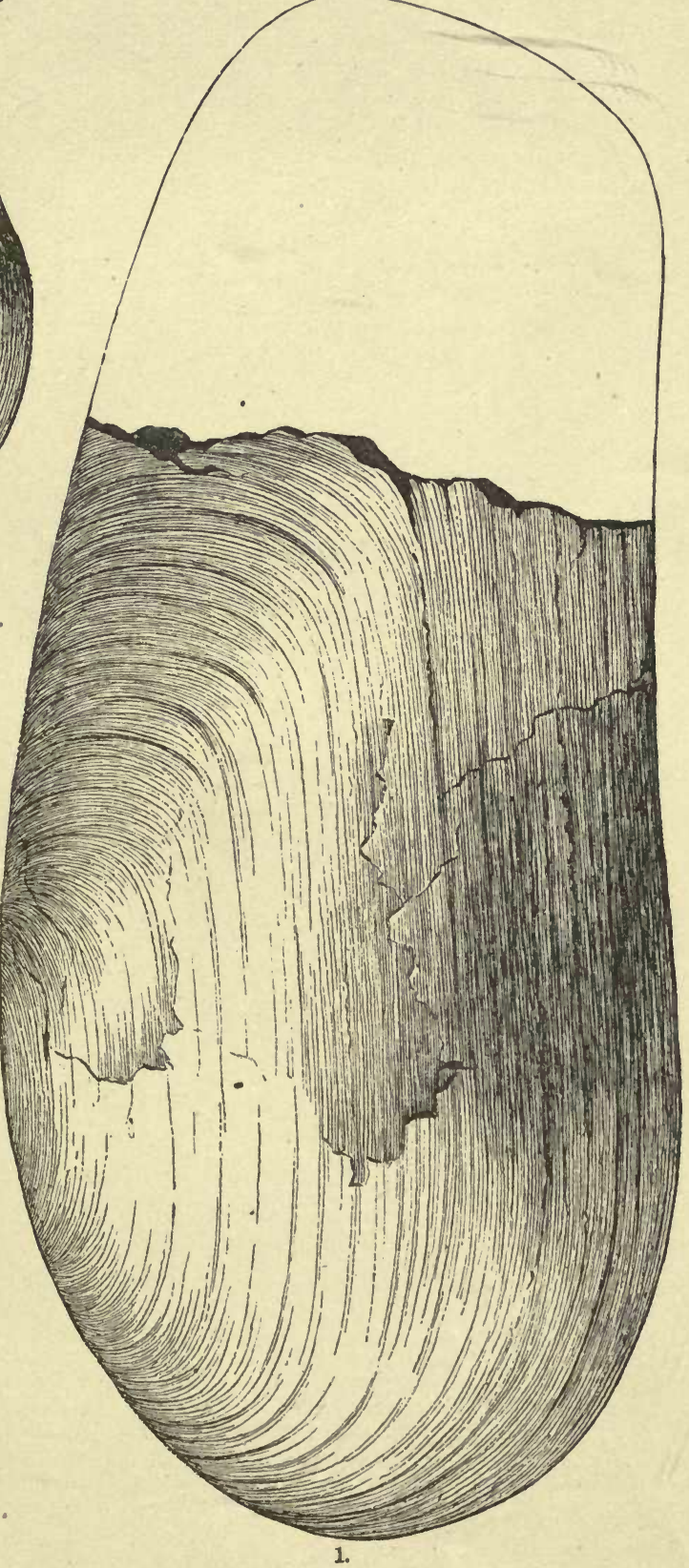

LARAMIE. 




\section{PLATE 17. LARAMIE.}

Uxio DAxג Meek \& Ilaylen. (Page 431.)

Fig. 1. Left sille view.

Fig. 2. Dorsal view of the same example.

F1G. 3. Right side viow of another example. After Meck. .

Unio Detreyanus M. \& II. (Page 431.)

Fra. 4. Left side view.

Fig. 5. Interior vierv of the same. After Meek.

\section{Corbicula occidextalis M. \& II. (Page 437.)}

Frg. 6. Left side riew of the type of $C$. binnisteri Meek.

Fig. 7. Dorsal view of the same; natural size.

(For other figures of $C$. occidentalis, see Plate XXIII.)

Spilderium plaxum M. \& H. (Page 439.)

Fia. 8. Exterior view of a left valve and ontline of a dorsal view of the same; natural size. After Meck.

Spmeriud recticardinale M. \& H. (Pago 439.)

Fig. 9. Exterior view of a left valve and ontline of a dorsal view of the same; natural size. After Meek.

Spinderium subellipticuar M. \& II. (Page 439.)

Fig. 10. Exterior view of the left valve, natural size, together with the same much enlarged. After Meek.

Spinzium formosum M. \& II. (Page 439.)

FIG. 11. Exterior view of the right side, natural size, together with side and dorsal views of the same much enlarged. After Meek. 


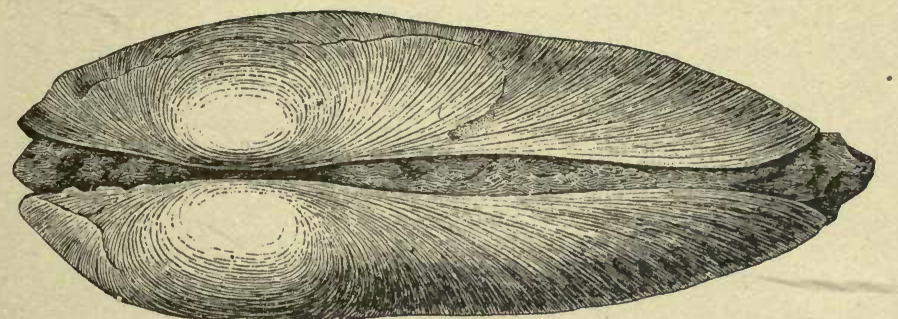

2.
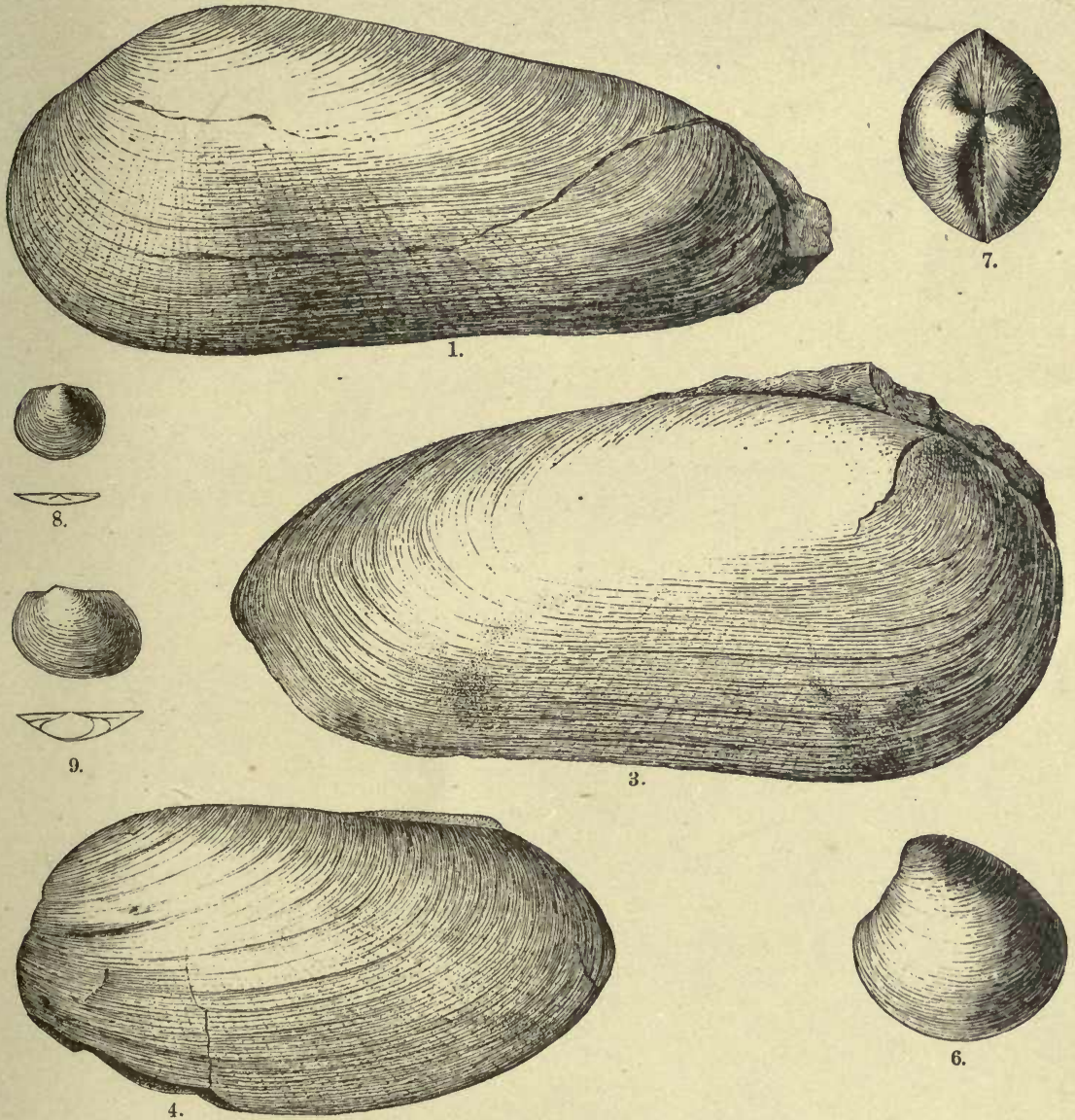

6.

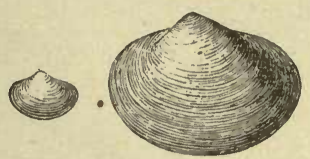

10.
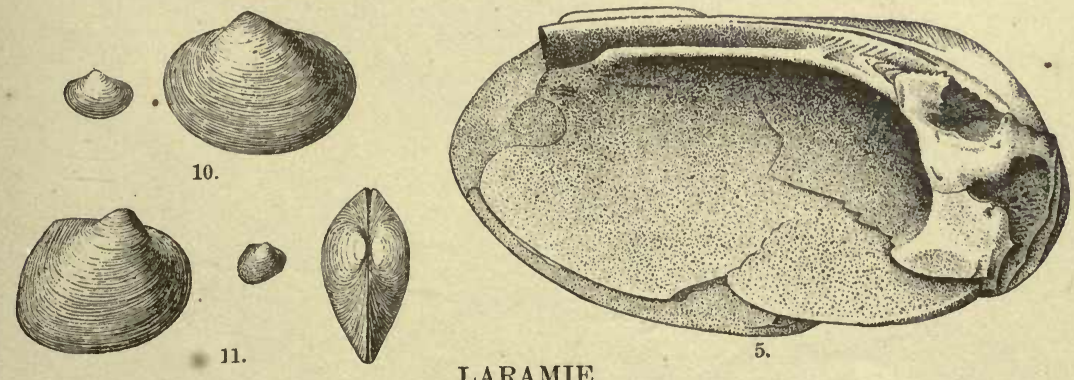

LARAMIE. 

. 
PLATE 18. LARAMIE.

\section{Unio DANE Meek \& Mayden? (Page 433.)}

Fic. 1. Exterior view of the right valve of an example from Black Buttes Station, Southern Wyoming.

Frc. 2. Interior view of a left valve from the same locality. (Both natural size.)

UNIo MENDAX White. (Page 433.)

Fig. 3. Exterior view of a left valve; adult.

FrG. 4. Similar view of a smaller right valve.

FIG. 5. Interior view of part of a right valve. (All from the Cañon of Desolation, Utah ; and all natural size.)

Corbula undifera Meek. (Page 440.)

Fra. 6. Right side view of an adult example.

Fra. 7. Dorsal view of the same.

FrG. 8. Left side view of a smaller example.

Frg. 9. Front view of the same.

Corbula undifera var. subundifera W. (Page 440.)

Fra. 10. Left side view of the type specimen.

Fra. 11. Dorsal view of the same, natural size.

Corbula mactriformis M. \& H. (Page 440.)

Fra. 12. Exterior view, left valve.

Fig. 13. Interior view of the same.

Fig. 14. Dorsal vien of the same.

Fra. 15. Interior view of the right valve of another example. (All natural size, and all after Meek.) 

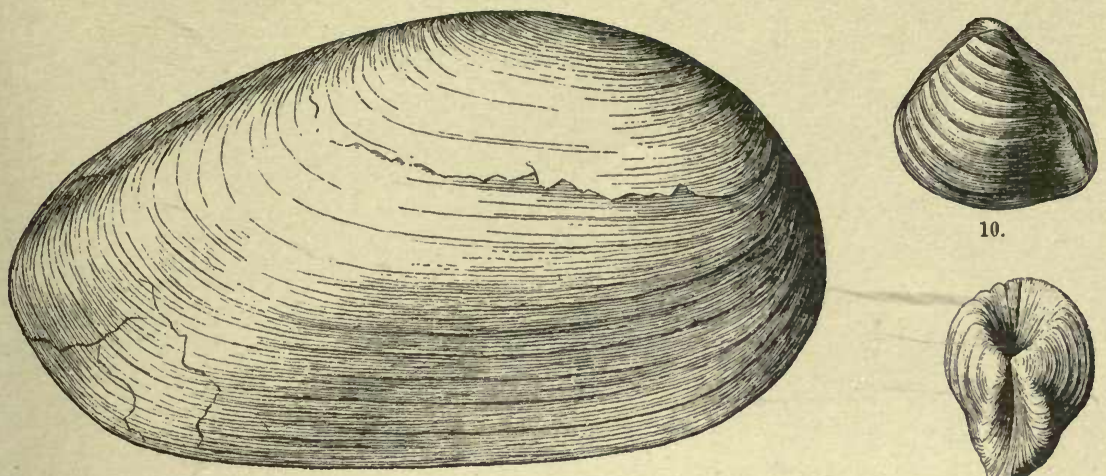

10.

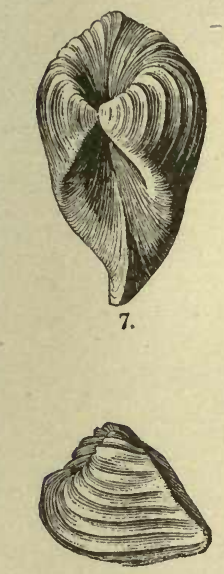

1.

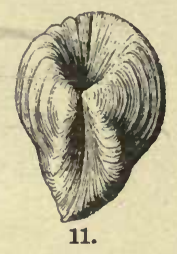

8.
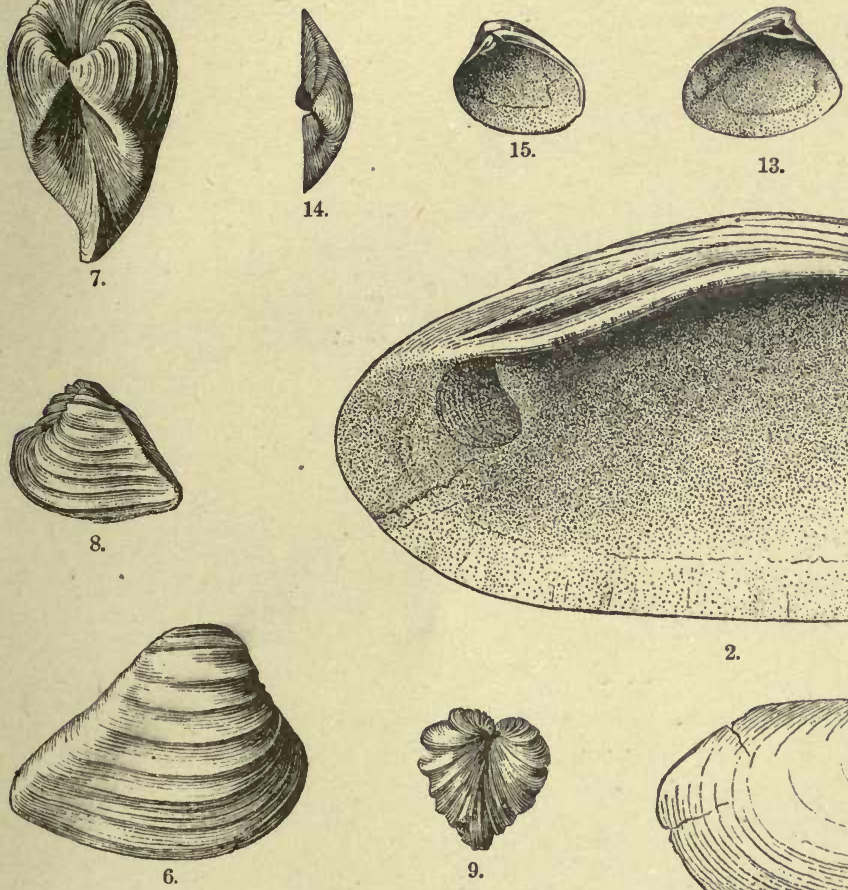

13.

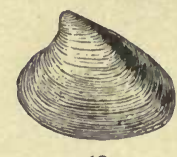

12.

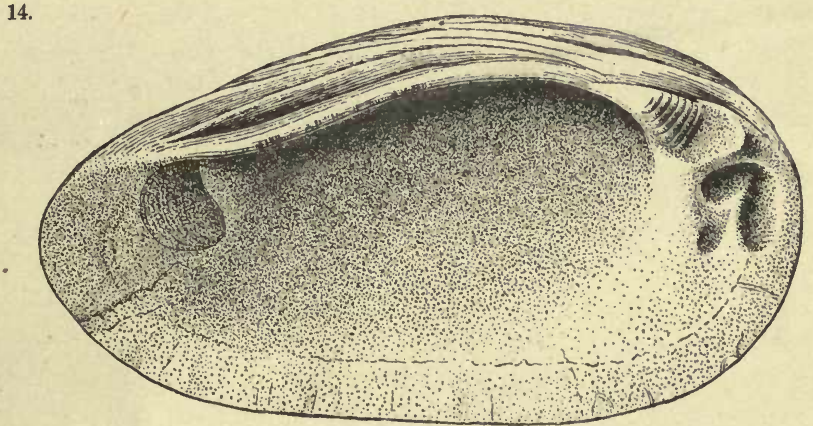

2.
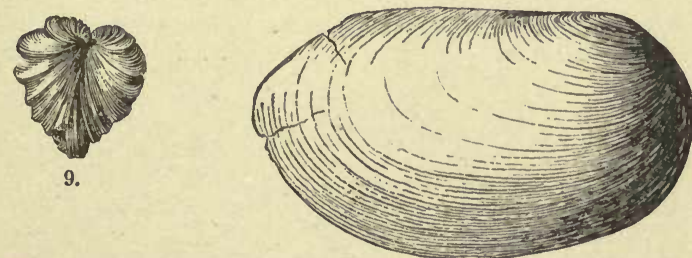

4.

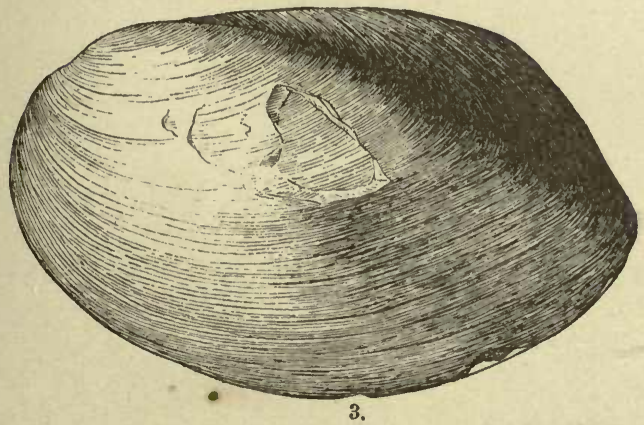

LARAMIE.

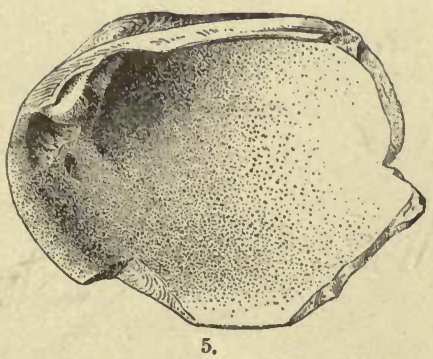




PLATE 19. LARAMIE.

\section{Unio sexectus White (Page 432.)}

Fra. 1. Exterior view of a portion of a right valve.

Fra. 2. Interior viow of a portion of a left valve.

(Both natural size.)

Unio goniambonatus W. (Page 433.)

Fra. 3. Left side vier, natural size.

Fra. 4. Dorsal view of the same.

(Both figures are partial restorations, the type specimen having been dis. torted by compression.)

Axodonta parallela W. (Pago 429.)

Fia. 5. Left side view, restored from fragments; natural size.

ANodonta propatoris W. (Page 429.)

FIa. 6. Left side view of an internal cast of large example.

Fra. 7. Right side view of a similar cast of a larger example.

Fig. 8. Dorsal view of the same."

Fig. 9. Fragment showing the edentulous hinge.

(All natural size.)

Combula subtrigonails Meek \& Hayden. (Page 442.)

Fig. 10. Exterior view of a left valve, natural size. After Meek.

FIG. 16. Exterior view of left valve of the variety C. perundata Meek.

FIG. 17. Similar view of another left valve of the same variety.

(Both natural size, and both after Meek.)

Fig. 15. Right side view of the variety C. tropidophora Meek, natural size.

FIG. 14. Right side view of the variety $C$. crassatelliformis Meek, natural size.

FIG. 11. Left side view of an example trom Crow Creek, Colorado; natural size.

FIG. 12. Dorsal view of the same.

FIG. 13. Left side view of another example from the same locality. 

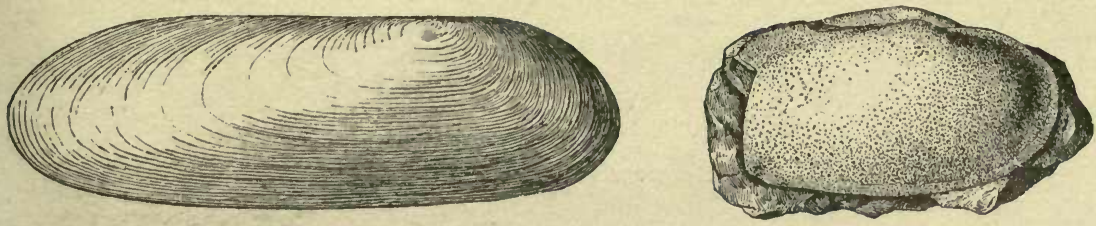

7.

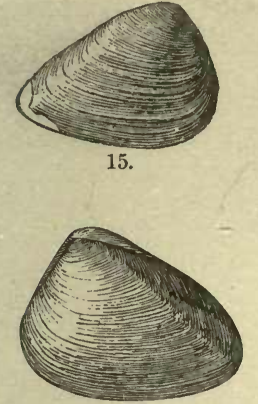

5.

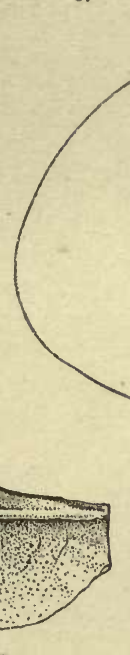

9.
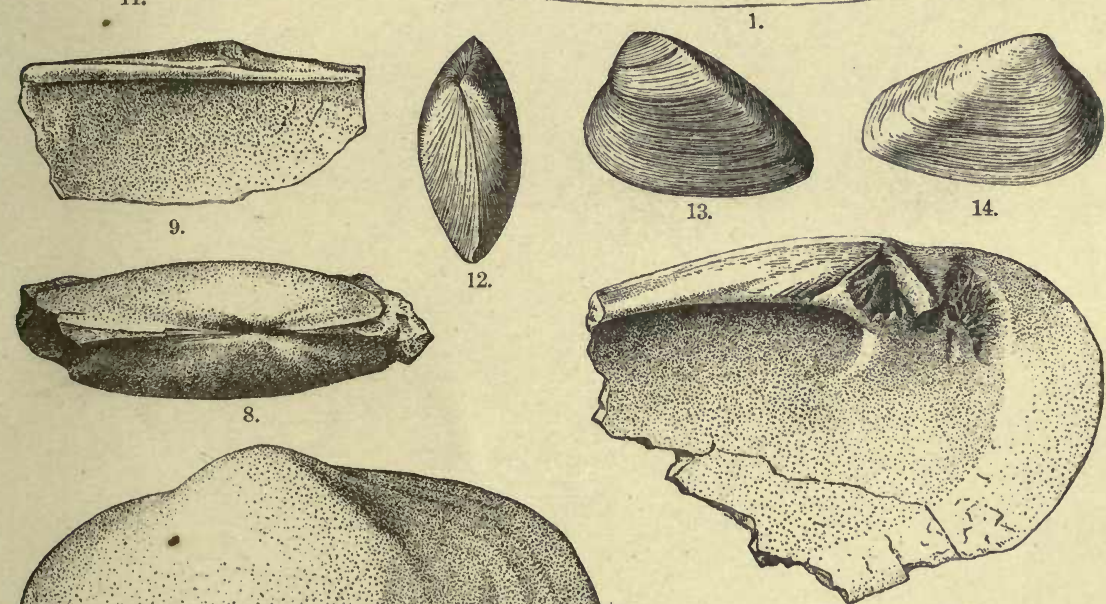

8.
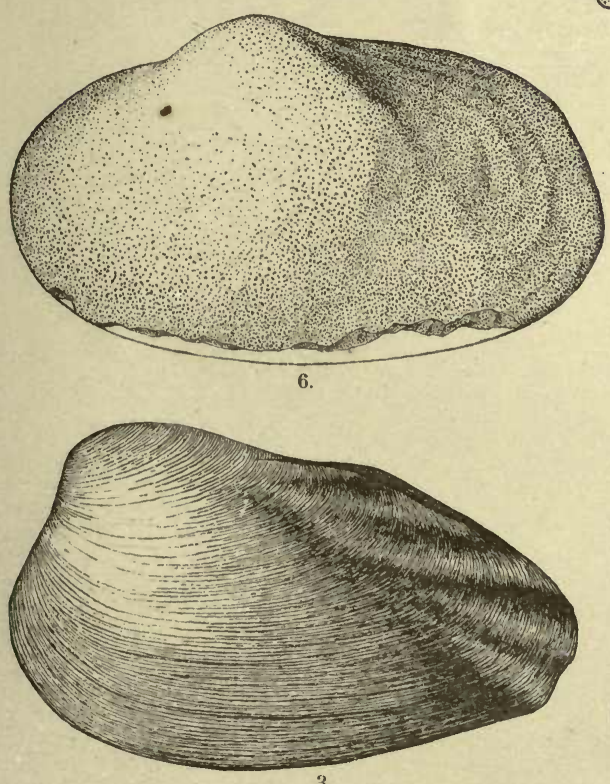

LARAMIE.
13.
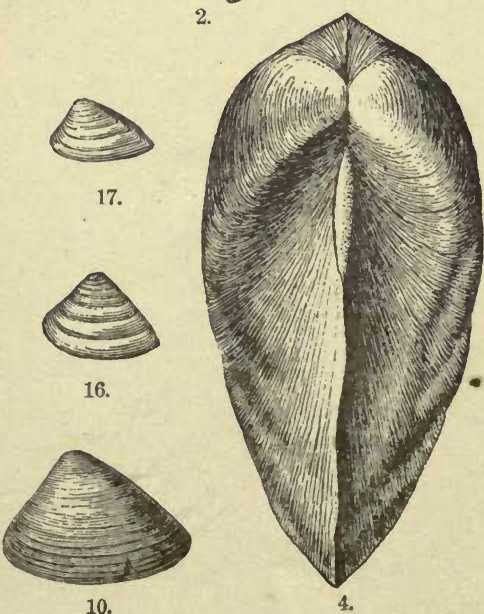

16.

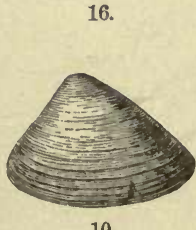

10.

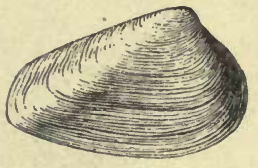

14.

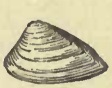

17. 


PLATE 20. LARAMIE.

Corbicula (Leptestmes) fracta Meek. (Page 439.)

FIG. 1. Copy of Mr. Meck's original figure.

Fig. 2. Left side view of a robust example.

Fig. 3. Dorsal view of the same.

FrG. 4. Left side view of a young example.

Fig. 5. Dorsal view of the same.

Fig. 6. Left side view of a more elongate, partially crushed example. (All natural sizo.)

\section{Corbicula Cleburat White. (Page 437.)}

Fig. 7 Left side view of an adnit example.

FIG. 8. Right side view of a smaller example.

Fig. 9. Interior vien of the same. (All natural size.)

Combicula subeliptica Meek \& IIayden. (Page 437.)

Fic. 10. Exterior view of a right valre; natural size.

Fia. 11. Interior view of the same.

\section{Corbicula nebrascensis M. \& H. (Page 437.)}

Fra. 12. Exterior of a left valve; natural size.

Fig. 13. Interior view of the same.

\section{Pisidiua saginatum W. (Page 440.)}

Frg. 14. Lateral view, enlarged.

Fia. 15. Front view of tho same. 
U. S. GEOLOGICAL SURVEY

ANNUAL REPORT 1882 Pl. 20

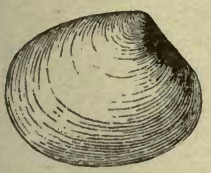

10.

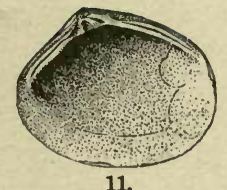

11.

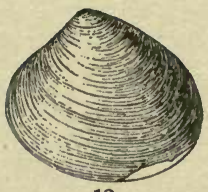

12

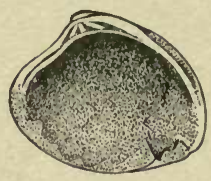

13.

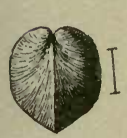

15.

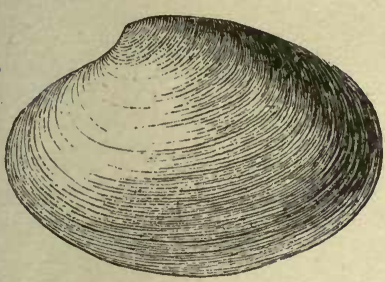

4.
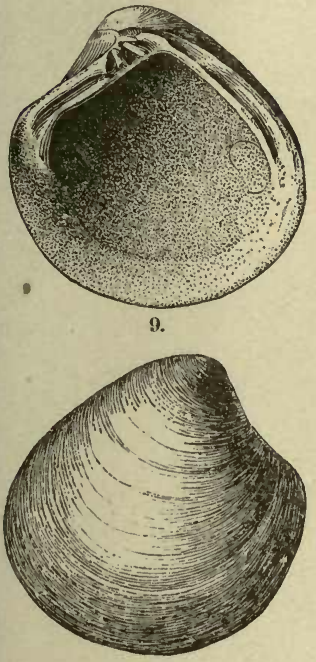

8.

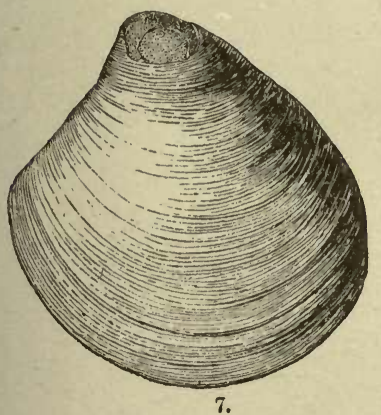

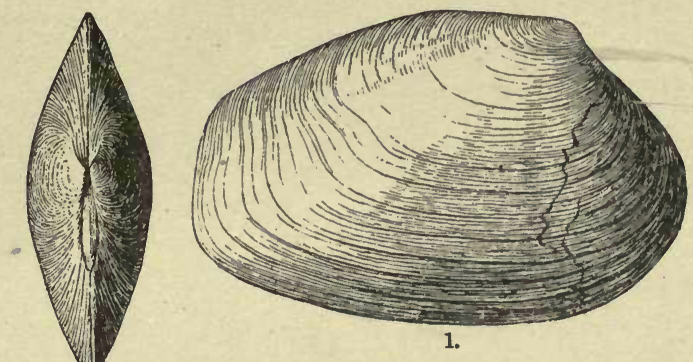

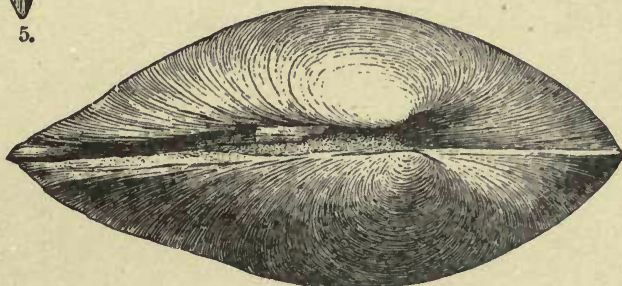

3.

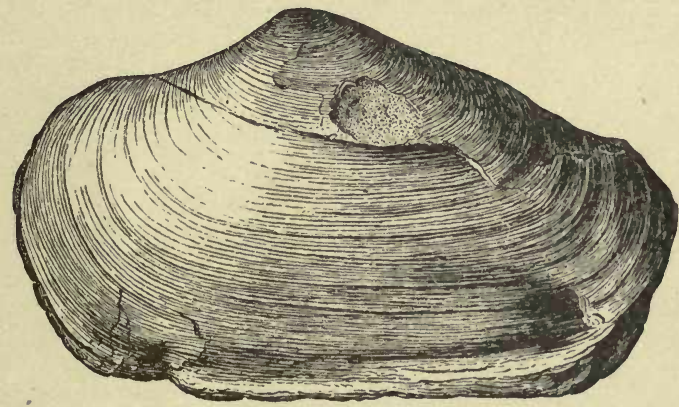

6.

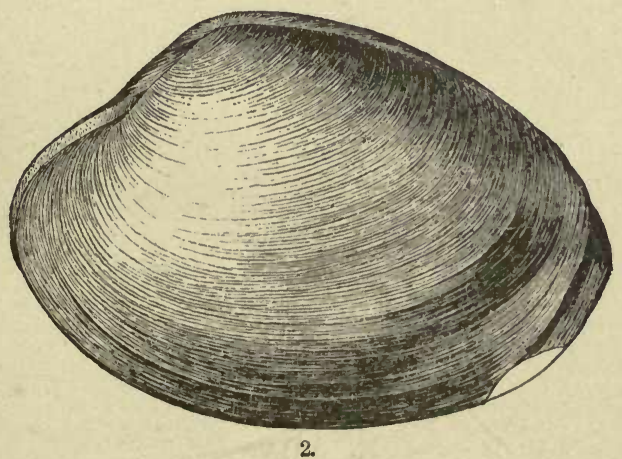

LARAMIE. 




\section{PLATE 21. LARAMIE.}

Conmicula nentmoudi White. (Pago 438.)

Frg. 1. Left valve of a large example, exterior view.

Fig. 2. Dorsal view of another example.

Fig. 3. Interior vierv of a left valve. (All natural size )

Corbicula augmexi IV. (Page 433.)

FIG. 4. Exterior view of a right valve.

Fig. 5. Interior view of the same.

FiG. 6. Dorsal view of another example. (All natural size.)

Conbicula umboxelia Meck. (Page 438.)

FIG. 7. Exterior view of a left valve.

Fig. 8. Interior view of the same.

FiG. 9. Dorsal view of another examplo.

Fig. 10. Front view of the same.

Conbicula (Leptestimes) macropistma IV. (Page 437.)

Frg. 11. Left side view of an adult example.

Fig. 12. Dursal view of the same.

Fig. 13. Left side view of another example.

Frg. 14. Interior view of a left valve 
U. S. GEOLOGICAL SURVEY
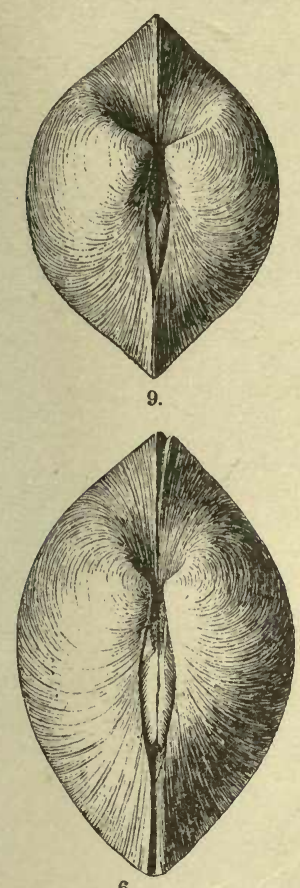

6.
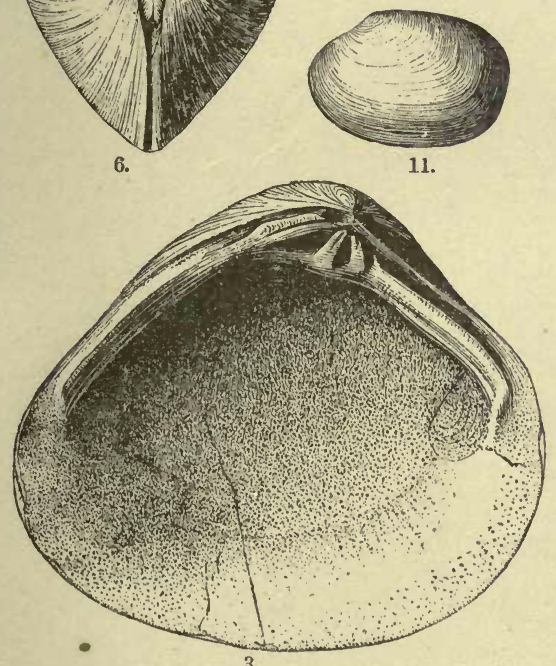

11.

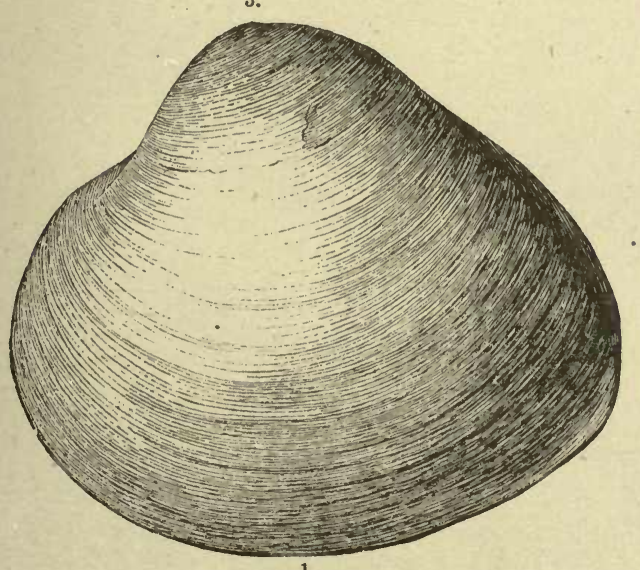

LARAMIE.
ANNUAL REPORT $1882 \quad P L, 21$
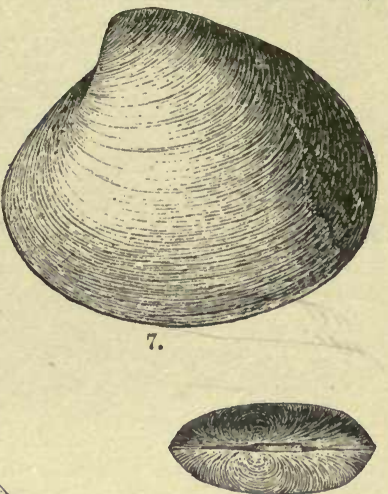

12.

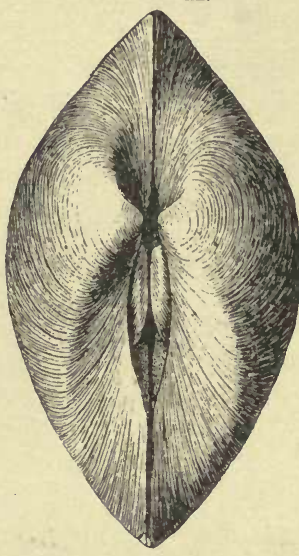

14.
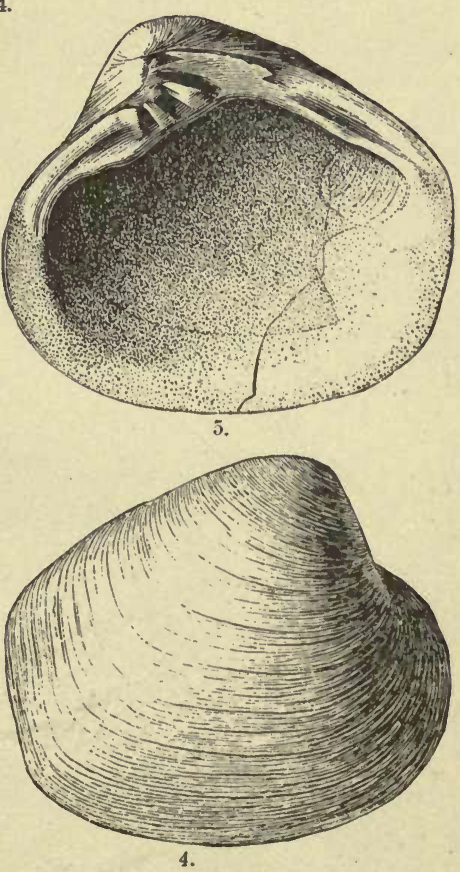



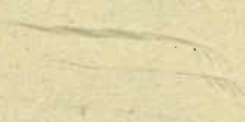

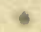

34 G 
PLATE 22. LARAMIE.

- Corbicula cytheriformis Meek \& Hayden. (Page 437.)

FIG. 1. Left side view of a large example.

FIG. 2. Right side view of a small example. (Both after Meek.)

Frg. 3. Right side view of an example from Southern Wyoming.

Fig. 4. Dorsal view of the same.

Frg. 5. Hinge view of left valve; from same locality.

Fig. 6. Similar view of right valve; from same locality. (All natural size.)

Corbicula (Leptesthes) planumbona Meek. (Page 437.)

Frg. 7. Right side view of an adult example.

Frg. 8. Dorsal view of the same.

FIG. 9. Left side view of a large example.

(All natural size.)

Corbicula (Leptesthes) cardiniaformis White. (Page 437.)

FIG. 10. Left side view of a large example.

Frg. 11. Dorsal view of the same.

Fig. 12. Exterior view of a right valve of a smaller example.

Frg. 13. Interior view of the same.

Fig. 14. Dorsal view of another example.

Fig. 15. Exterior view of a left valve, less transversely elongate than usual. (All natural size.) 
U. S. GEOLOGICAL SURVEY
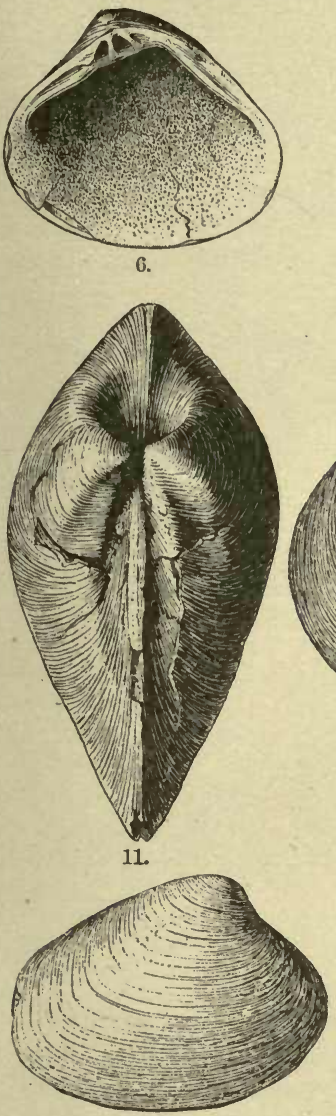

12.
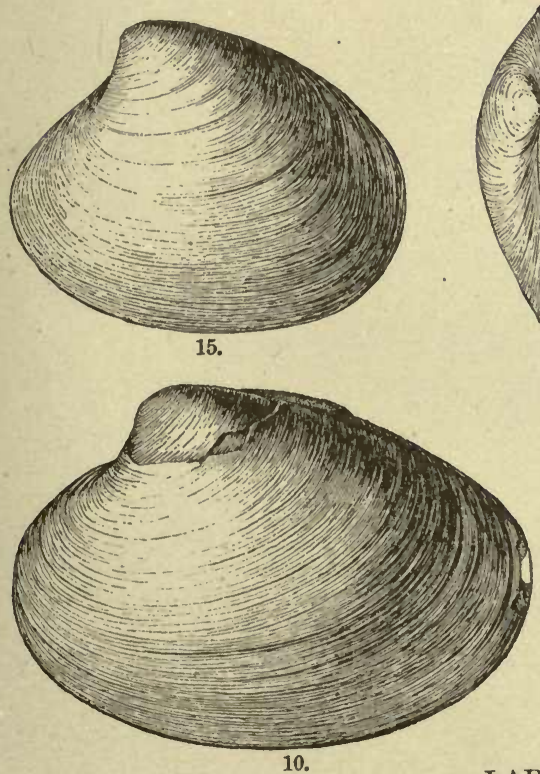

LARAMIE.

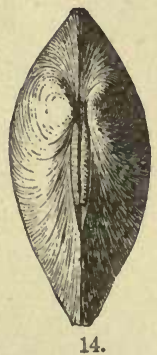

ANNUAL REPORT 1882 Pl. 22
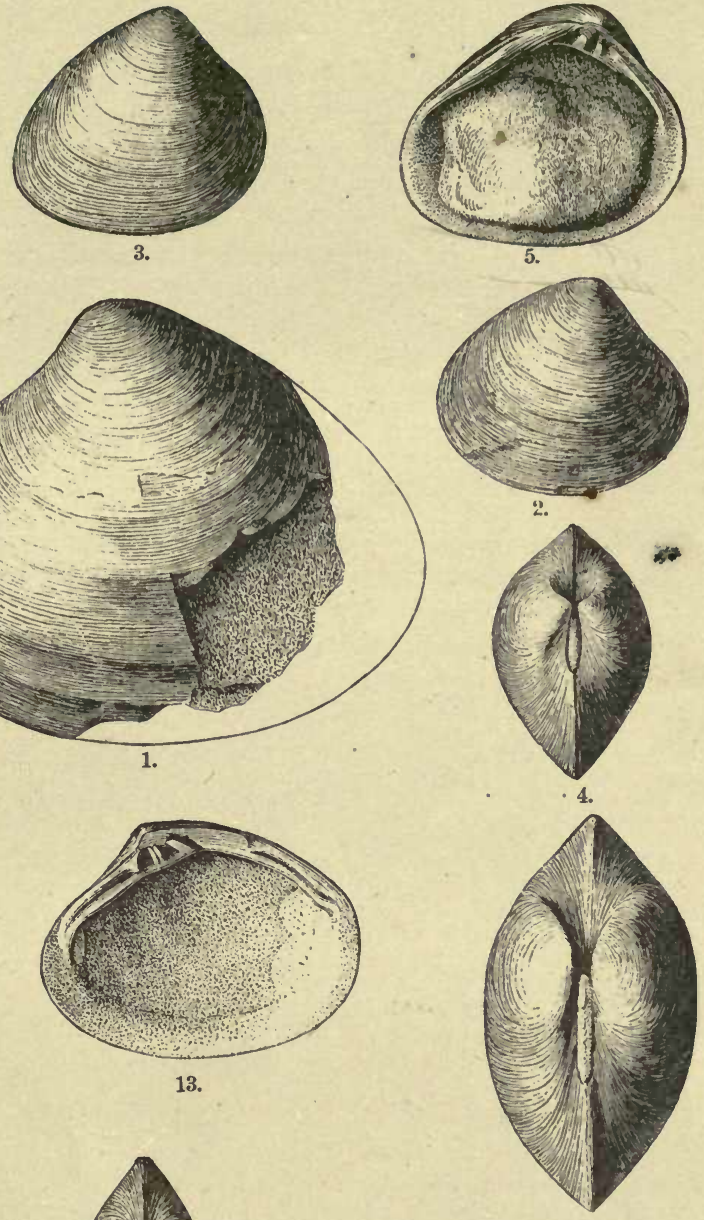

8.
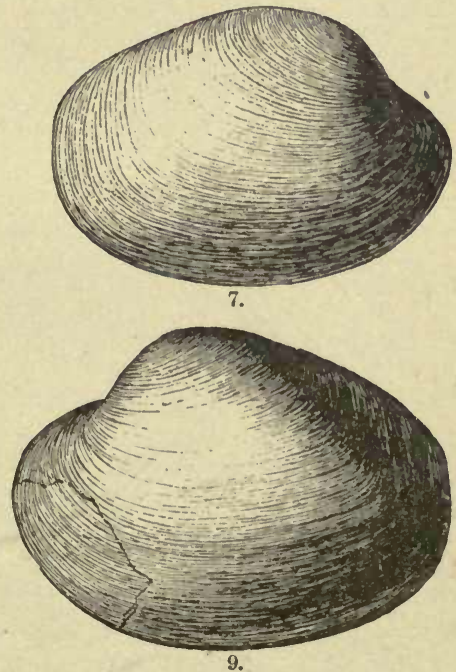

9. 

$+$

눈

wis $7 x$ 


\section{PLATE 23. LARAMIE}

Corbicula occidentalis Meek \& Hayden. (Page 437.)

FIG. 1. Exterior view of the right valve of an example from Yampa River. Northwestern Colorado.

Fig. 2. Interior view of the samo.

FIG. 3. Dorsal view of the same; the left valve restored in symmetry with the right

Frg. 4. Left side view of an example from the same locality of less proportionate height than usual.

Fig. 5. Dorsal view of the same.

FIG. 6. Copy of one of Mr. Meek's original figures.

(All natural size.)

Corbicula obesa White. (Page 437.)

Fig. 7. Exterior view, right side.

Fig. 8. Dorsal view of the same.

Fig. 9. Front view of the same.

FIG. 10. Dorsal view of another example.

Frg. 11. Interior view of a left valve.

(All natural sizo.)

Neritina volvilineata W. (Page 458.)

FIG. 12. Lateral view, enlarged.

Fig. 13. Opposite view of the same:

\section{Neritina bruneri W. (Page 459.)}

Frg. 14. Lateral view, natural size; showing color-markings.

Fig. 15. Opposite view of the same.

Neritina (Velatella) baptista W. (Page 458.)

FIG. 16. Dorsal view of the type specimen from Wyoming, showing the color-markings; enlarged.

Fig. 17. Lateral view of the same.

Fig. 18. Dorsal view of an example from Northeastern Colorado, showing the colormarkings; enlarged.

Fig. 19. Lateral view of the same.

Fig. 20. Inferior view of the same.

Melanopsis americana W. (Page 461.)

FIG. 21. Lateral view, enlarged.

FIG. 22. Opposite view of the same, showing aperture and broken outer lip.

FIG. 23. Similar view of the proximal portion of the same more enlarged, showing callus of inner lip and canal.

Limina (Pleurolimnae) tenuicostata M. \& H. (Page 445.)

Fig. 24. Lateral view, natural size and enlarged. After Meek.

Cassiopella turricula W. (Page 464.)

Frg. 25. Lateral view of the type specimen; the proximal volutions a little broadened by compression.

Fig. 26. Similar view of another example.

FIG. 27. Similar view of a smaller example.

Fig. 28. Lateral view of another example showing the umbilicus, and approximately the outline of the aperture.

Fig. 29. Inferior view of a basal fragment of another example showing the umbilicus. 
U. S. GEOLOGICAL SURVEY

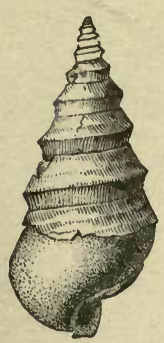

26.

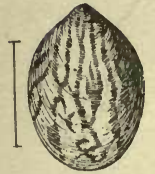

18.

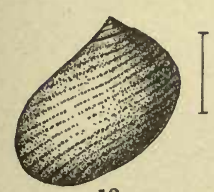

12.
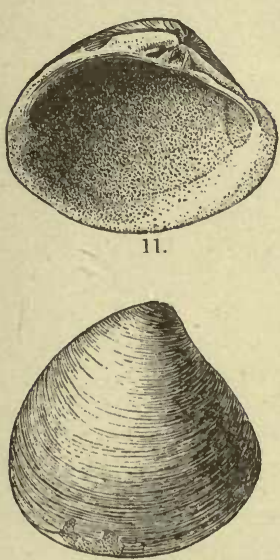

6.

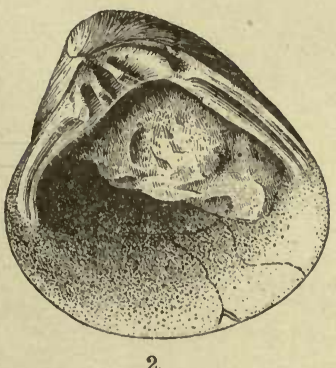

2.

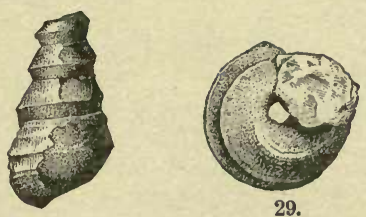

27.

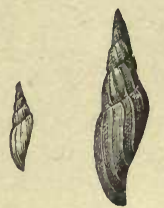

24.

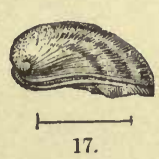

17.

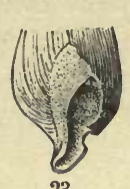

ANNUAL REPORT $1882 \quad \mathrm{Pl} .23$

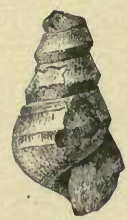

28.
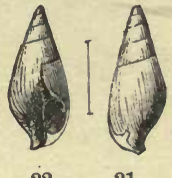

22. 21.

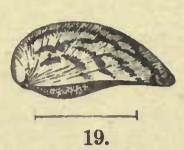

19.

20.

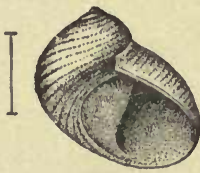

13.

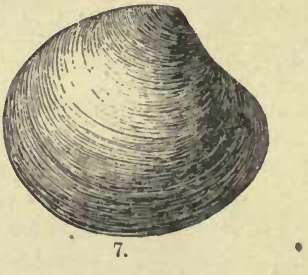

8.

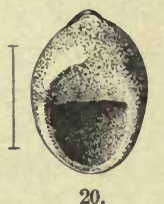

25.

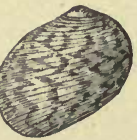

14.

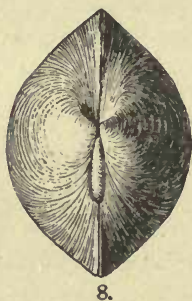

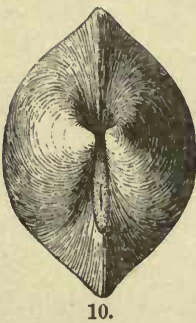

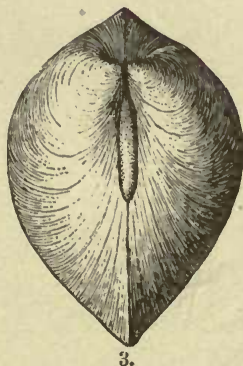

4.

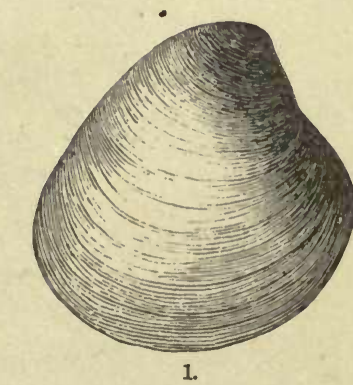

LARAMIE. 



\section{PLATE 24. LARAMIE.}

\section{Viviparus retusus Meek \& Hayden. Page 467.)}

Fig. 1. Lateral view of an adult example.

Frg. 2. Similar view of another example.

FIG. 3. Lateral view of another example, showing aperture. (All natural size.)

Viviparus conradi M. \& H. (Page 467.)

Fig. 4. Lateral view of an adult example.

Frg. 5. Opposite view of the same.

Fig. 6. Another example, more than usually elongate.

\section{Viviparus leidyi M. \& H. (Page 467.)}

Fig. 7. Lateral view of the type specimen. After Meek.

Viviparus Leidyi var. formosus M. \& H. (Pago 467.)

Frg. 8. Lateral view of the type specimen.

Fig. 9. Opposite view of the same. After Meek.

\section{Viviparus trochifolmis M. \& H. (Page 46\%.)}

Frgs. 10, 11, 12, 13, 14, 15, and 16. Lateral views of üifferent examples; all natural size.

Tulotoma trompsoni White. (Page 467.)

Figs. 17, 18, 19, 20, and 21. Lateral views of different examples, showing the ornamentation of the first to be nearly like that of $\nabla$. trochiformis, and the increasing size of the nodes towards the higher numbers; all of natural size, and all from Northern Colorado, east of the Rocky Mountains.

Fig. 22. Lateral view of an example from Southern Wyoming, west of the Rocky Mountains.

Viviparus peculiaris M. \& H. (Page 467.)

Fig. 23. Lateral view of the type specimen of Meek \& Hayden.

Frg. 24. Opposite view of the same, natural size.

\section{Viviparus plicapressus W. (Page 467.)}

Fig. 25. Lateral view, natural size.

Frg. 26. Similar view of another example.

Acroloxus minutus M. \& II.

Fıg. 27. Apical view, magnified to four diameters. 
U. S. GEOLOGICAL SURVEY

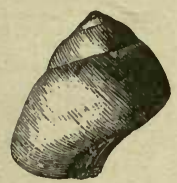

1.

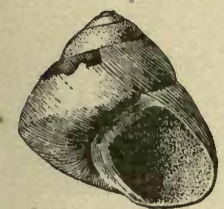

3.
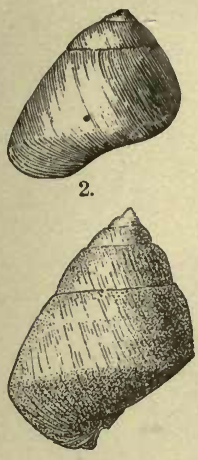

10.

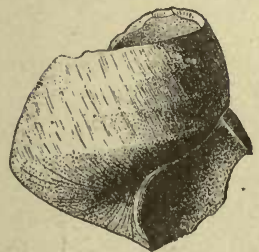

14.
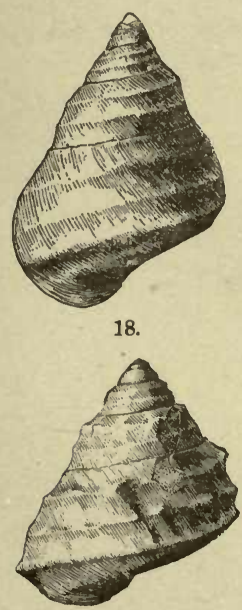

19.
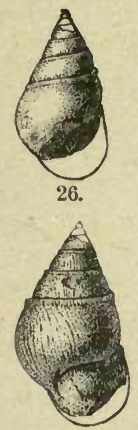

25.

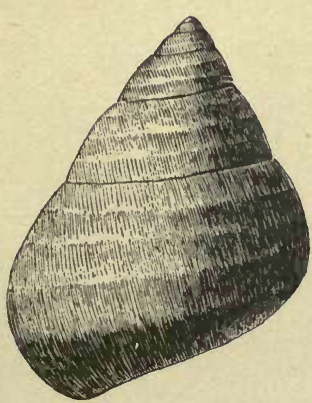

9.

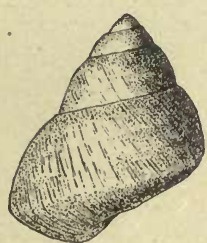

11.
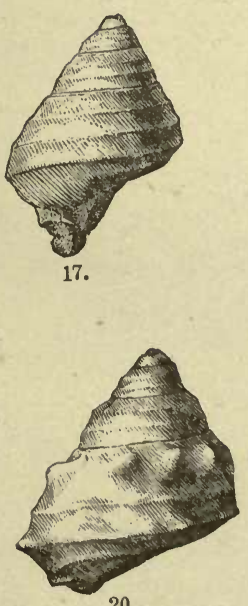

20.

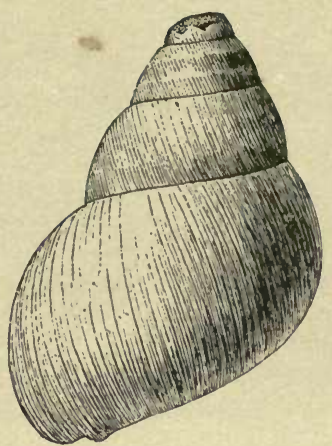

7.

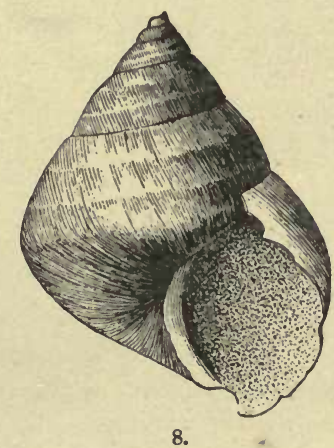

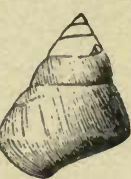

23.

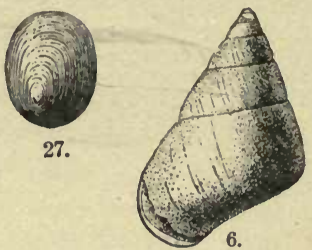

8
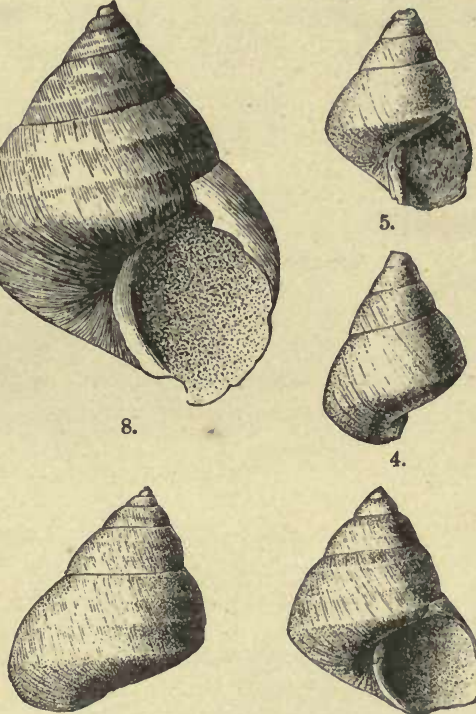

12.

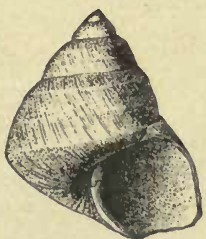

- 13
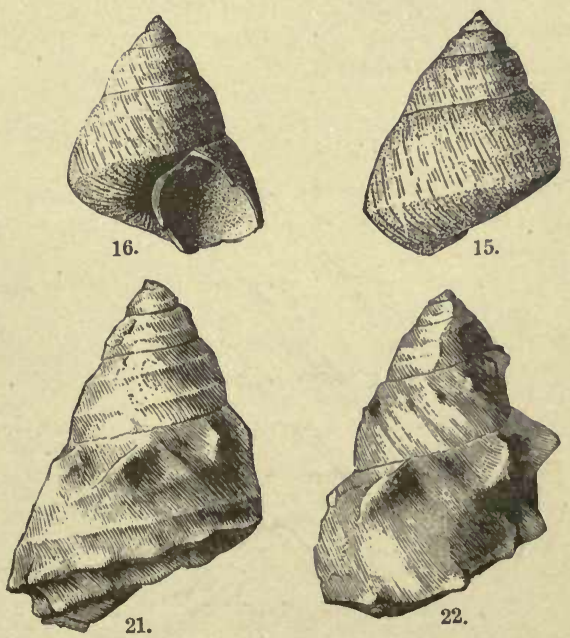

LARAMIE. 



\section{PLATE 25. LARAMIE.}

\section{Prrysa coper White. (Page 450.)}

Frg. 1. Lateral view, natural size.

FıG. 2. Opposite view of the same.

Physa relix W. (Page 450.)

FIG. 3. Lateral viow of an imperfect example, natural size.

\section{Bulinus disjunctus W. (Page 451.)}

Fig. 4. Lateral view, natural size.

FIG. 5. Opposite view of the same.

Bulinus atavus W. (Page 450.)

Fra. 6. Lateral vier, natural size.

Fig. 7. Opposite view of the same.

Bulinus Longinsculus Meek \& Hayden. (Page 451.)

Fig. 8. Two lateral views of the same example, natural size. After Meek.

Bununus rhombordeus M. \& H. (Page 451.)

Fig. 9. Lateral view, natural size. After Meek.

Bulinus subelongatus M. \& H. (Page 450.)

Frg. 10. Lateral view, natural size.

Frg. 11. Opposite view of the same. After Meek.

\section{Helix ranablensis W. (Page 454.)}

Fig 12. Lateral view of an internal cast of the last volutions, showing the grooves left by the internal ridges near the aperture; natural size.

Fig. 13. Upper view of the same.

Fig. 14. Under view of the same.

Columa teres M. \& H. (Page 454.)

Fig. 15. Lateral viow, natural size, and enlarged. After Moek.

Columa vermicula M. \& H. (Page 454.)

Fra. 16. Lateral view, natural size, and enlarged. After Meek.

Viviparus prudentius W. (Yage 467.)

Fig. 17. Lateral view, natural size.

Fig. 18. Opposite view of the same.

Viviparus panguitchensis W. (Page 46\%.)

Fig. 19. Lateral view of an internal cast.

FIG. 20. Opposite view of another example, showing a part of the surface markings.

Fig. 21. Lateral view of another example, showing a portion of the natural surface of the shell.

(All natural size.)

Viviparus reynoldsianus M. \& $\mathrm{H}$. (Page 46\%.)

Fig. 22. Lateral view, natural size.

Fig. 23. Opposite view of the same example.

Tunumastus mimantifolins M. \& II. (Page 454.)

Fig. 24. Apertural and opposite views of an example not quite adult; uatural size. 
O. S. GEOLOGICAL SURVEY

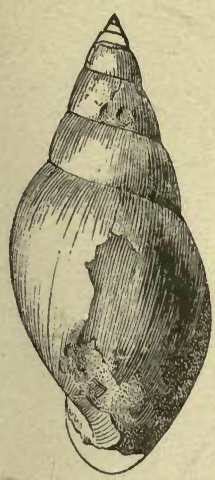

$-5$
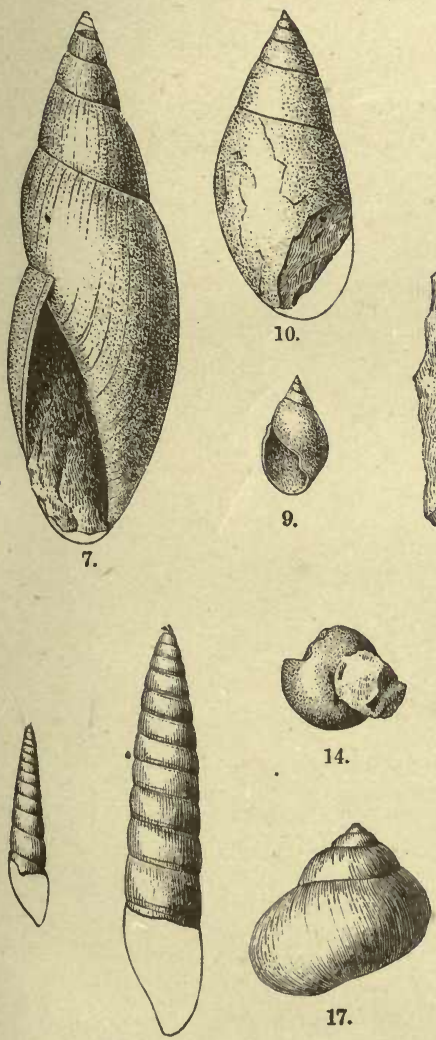

9.

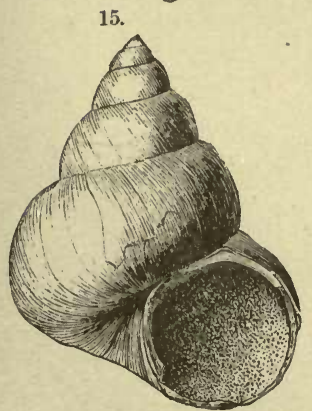

23.
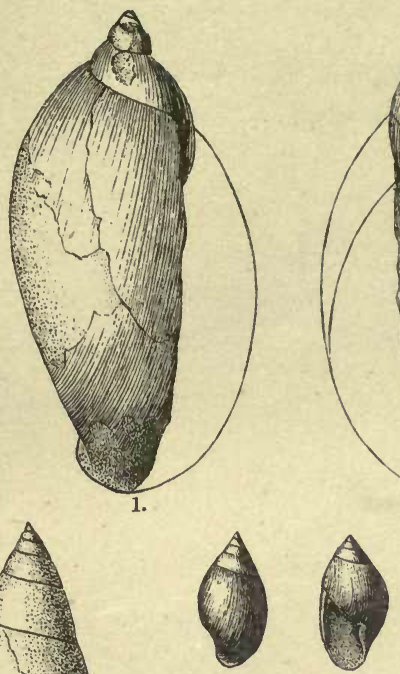

8.
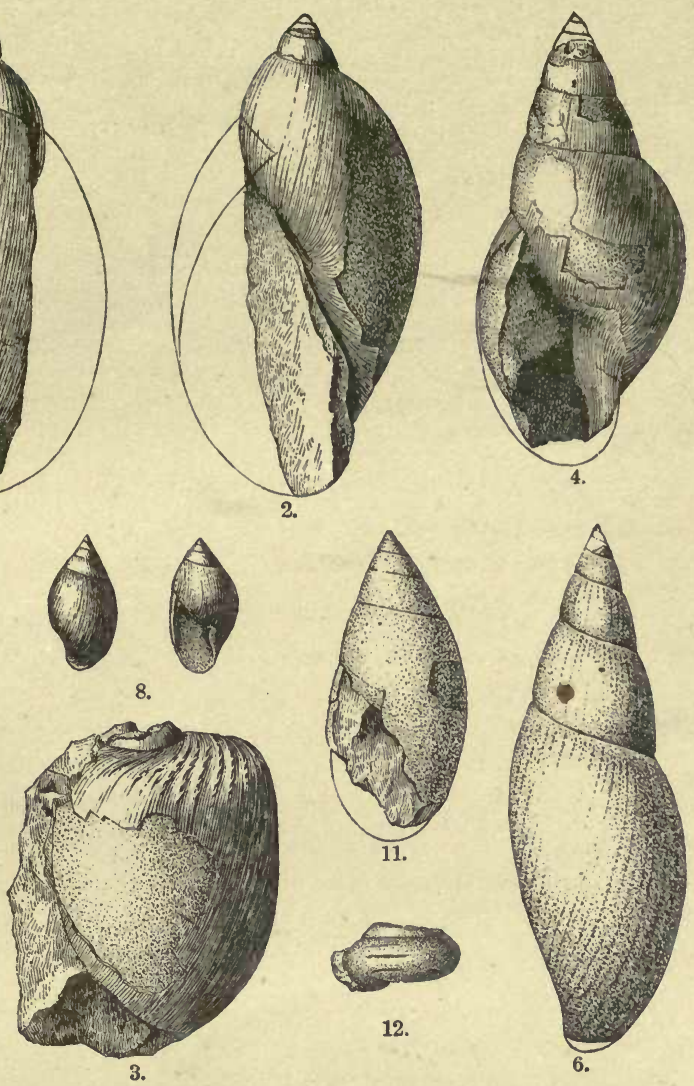

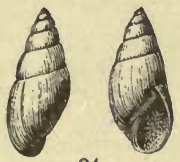

24.
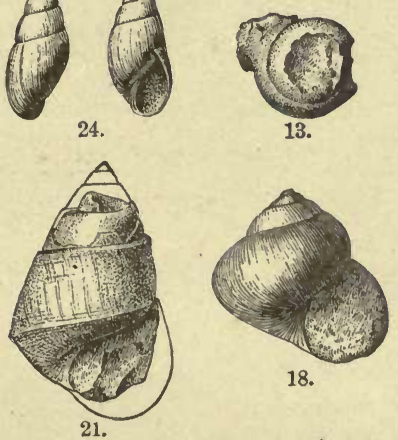

18.

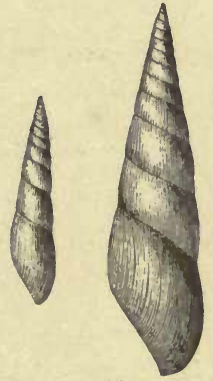

15.

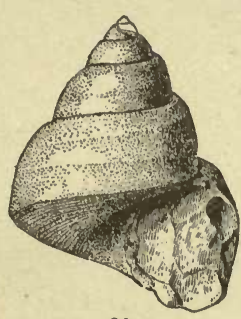

20.

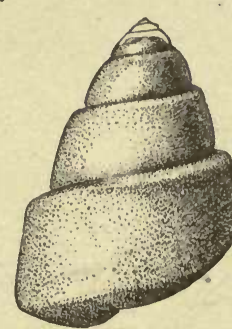

19.

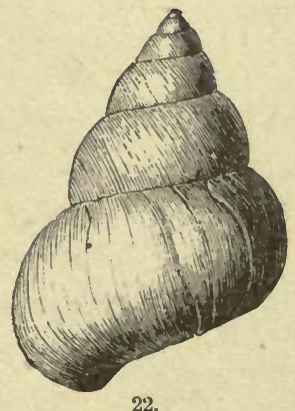





\section{PLATE 26. LARAMIE.}

Melania wromingensis Meek. (Page 460.)

FiG. 1. Lateral view, showing the outline of the outer lip.

Fig. 2. Similar view of another example.

FIG. 3. Similar view of the distal volutions, showing those of the apical portion to be destitute of spines.

Melania insculpta M. (Page 460.)

Fig. 4. Fragment of au adult example.

Fig. 5. Fragment of a smaller example.

(Both natural size, and both from Northeastern Colorado.)

Goniobasis convexa Meek \& Hayden. (Page 463.)

FIG. 6. Lateral view, natural size.

FIG. 7. Opposite view of the same example.

Goniobasis Convexa var. IMPressa M. \& H. (Page 463.)

FIG. 8. Lateral view, natural size.

FIG. 9. Opposite view of the same example.

Goniobasis omita M. \& H. (Page 463.)

FiG. 10. Apertural and opposite views; natural size. After Meek.

Goniobasis tenuicarinata M. \& H. (Page 463.)

FIG. 11. Apertural and opposite views; natural size.

Goniobasis Gracilenta M. (Page 463.)

Fig. 12. Apertual and opposite views of Mr. Meek's type specimen.

Frg. 13. Lateral view of an example from Crow Creek, Colorado. (Both natural size.)

LIMNeA : COMPACTILIS M. (Page 445.)

Fig. 14. Apertural and opposite views of Mr. Meek's type speeimen, natural size.

Goniobasis Nebrascensis M. \& H. (Page 463.)

FIG. 15. Lateral view, natural size.

Fia. 16. Opposite view of the same example.

Goniobasis invenusta M. \& H. (Page 463.).

Fra. 17. Lateral view of the type specinen of Meek \& Hayden, natural size.

Goniobasis sublevis M. \& H.. (Page 463.)

Fig. 18. Lateral view of the type speeimen of Meek \& Hayden, natural size.

Cerithidea ? nebrascensis M. \& H. (Page 463.)

Fig. 19. Apertural and opposite views of the type specimen of Meek \& Hayden, enlarged. After Meek.

Micropyrgus minutulus M. \& H. (Page 465.)

Fig. 20. Apertural and opposite views of the type speeimen of Meek \& Hayden, enlarged.

Campeloma producta White. (Page 469.)

Fig. 21. Lateral view of an elongate example, regarded as the type.

Fig. 22. Opposite view of the same.

Fig. 23. Lateral view of a more robust example.

Fig. 24. Opposite view of the same.

FIG. 25. Lateral view of a subearinate variety.

Fig. 26. Similar view of another example of the same variety.

Fig. 27. Similar view of another example of the same variety.

- (All natural size.) 
U.S. GEOLOGICAL SURVEY

ANNUAL REPORT 1882 Pl.26
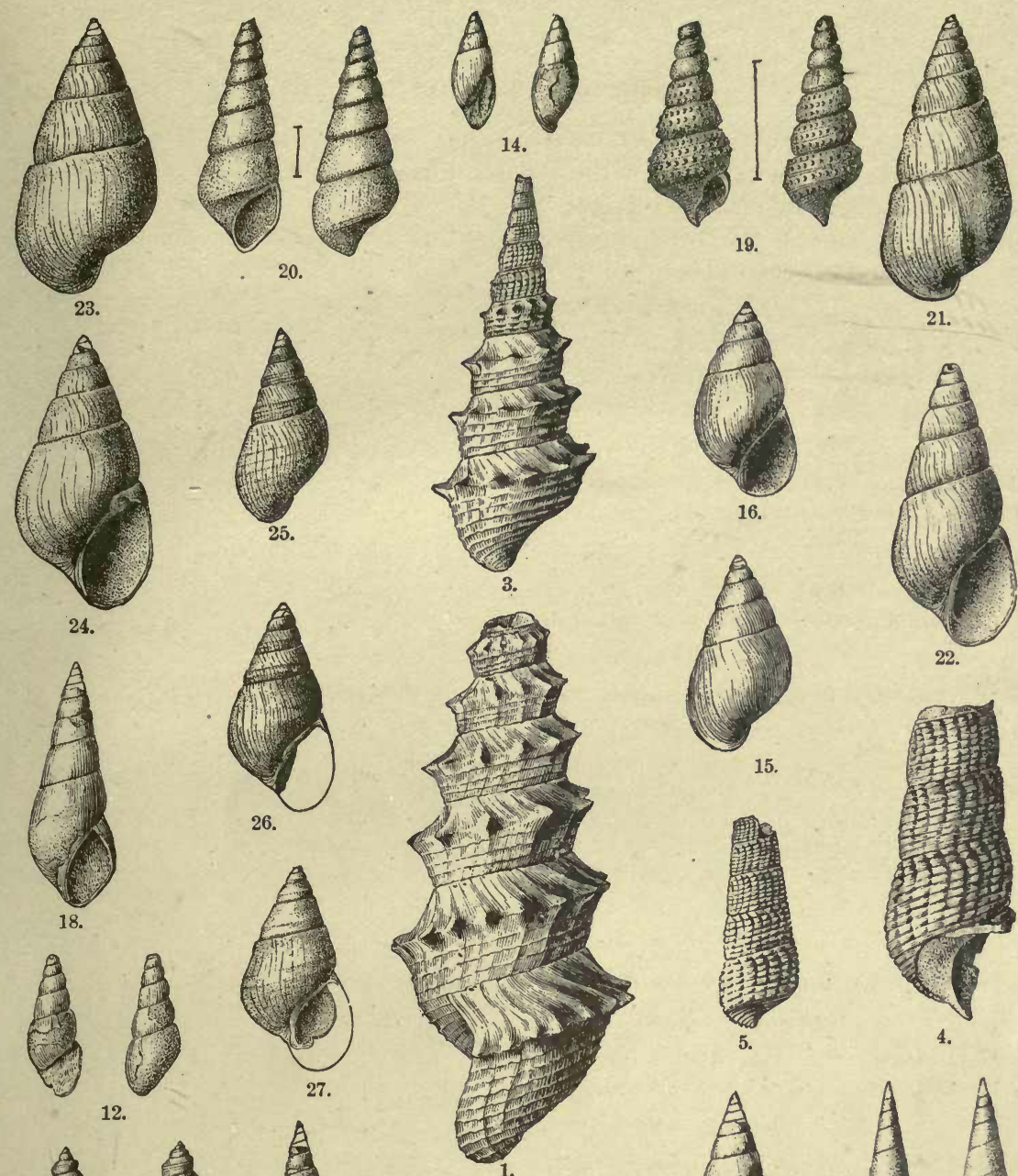

)
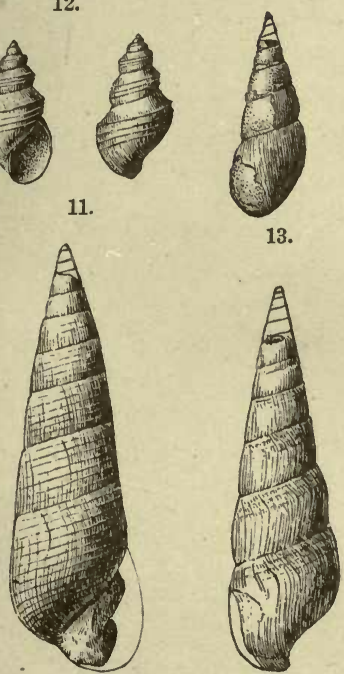

7.

8.
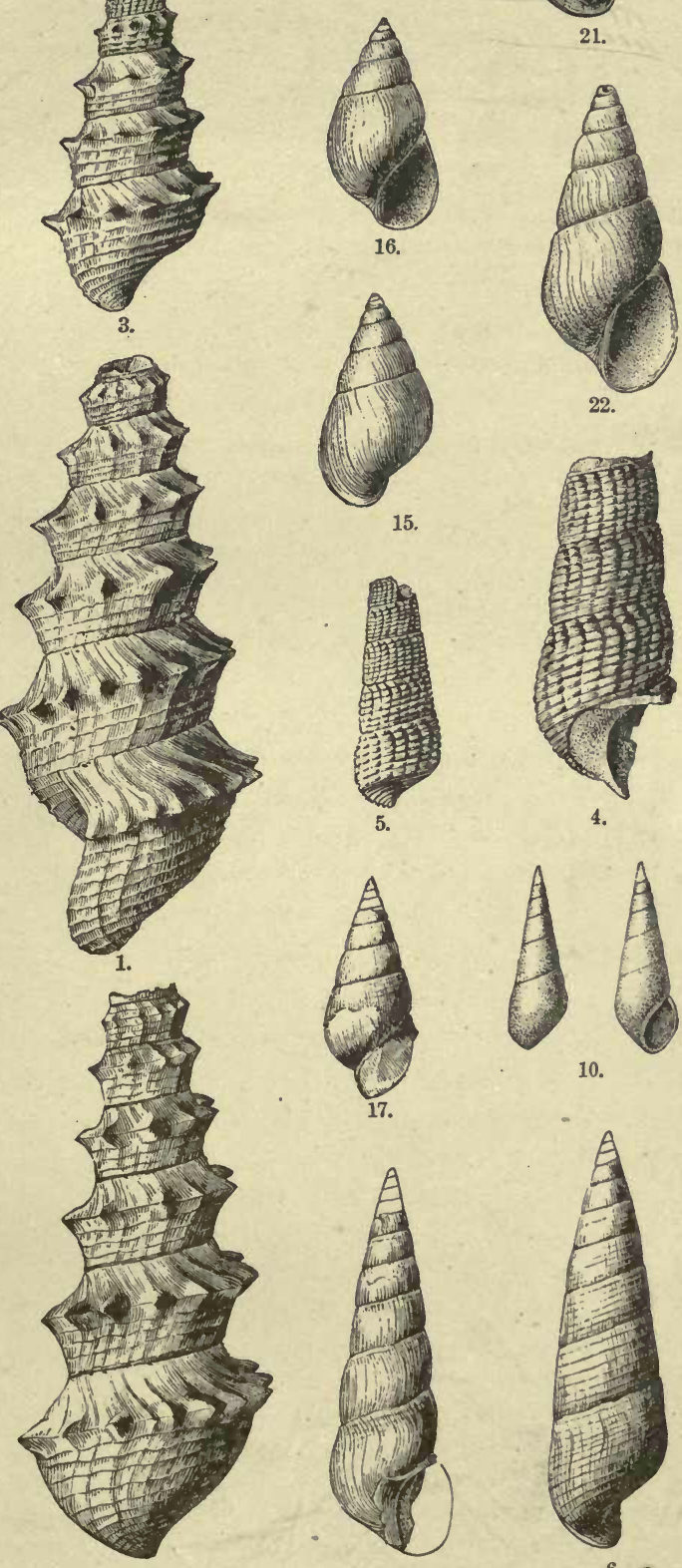

4.

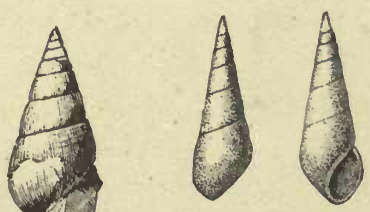

10.

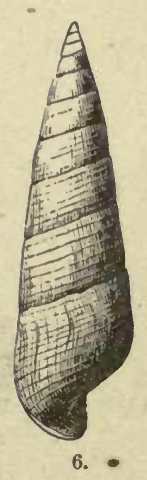

LARAMIE. 

U. S. GEOLOGICAL SURVEY

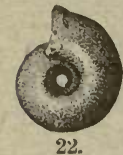

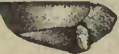

23.

(6)

Q (0)

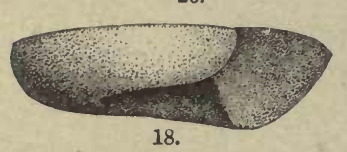

18.
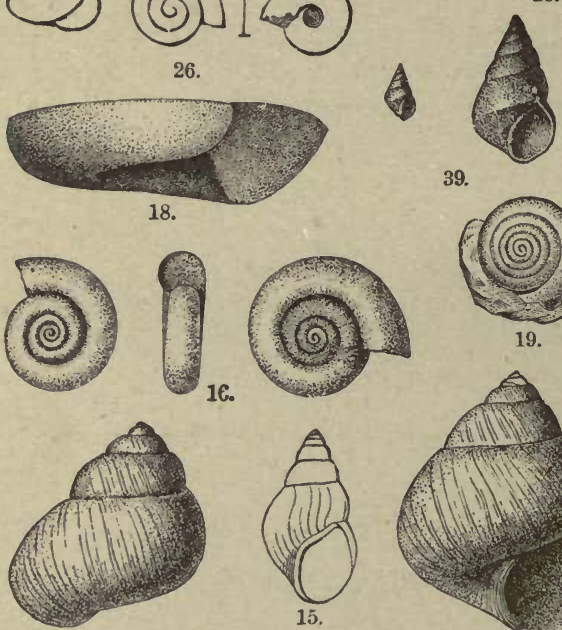

13

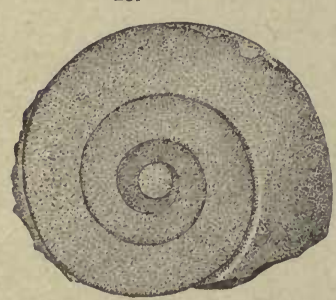

17.
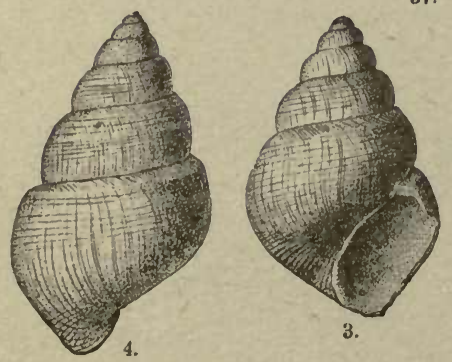

3.

If

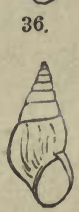

37.

11.

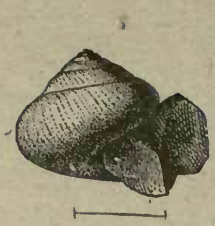

30.

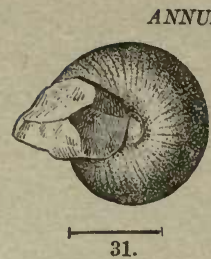

(3) I
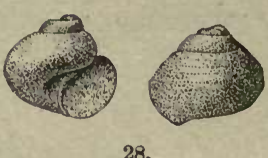

28.

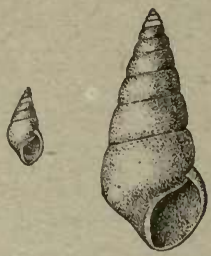

$Q \stackrel{\circ}{x} \odot$

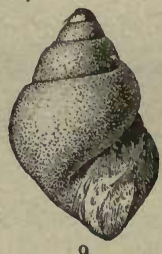

9.

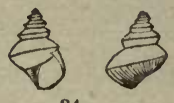

34.

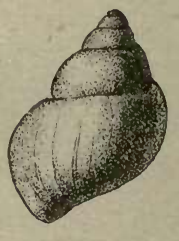

8.

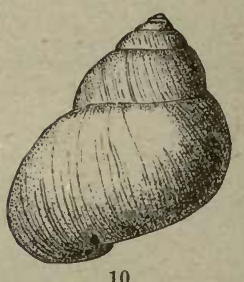

10.
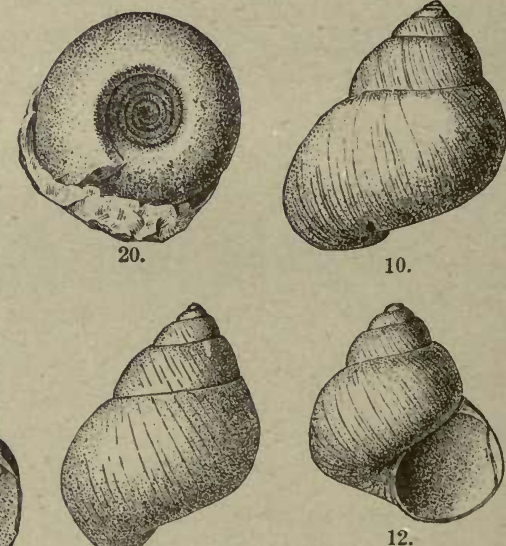

14.

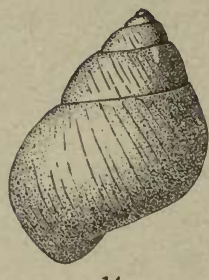

12.
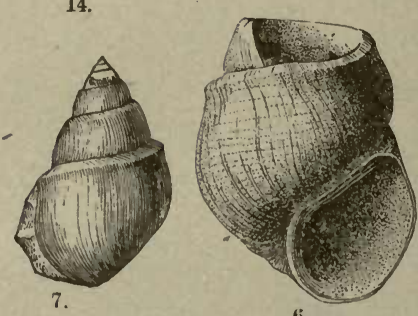

6.
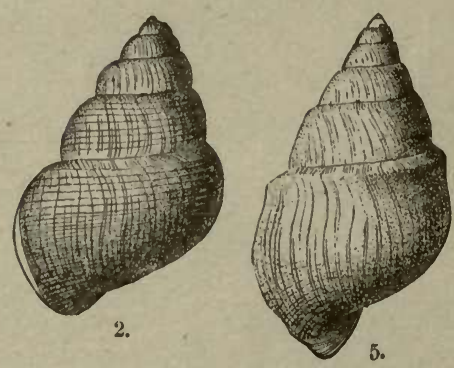

2.

LARAMIE. 


\section{PLATE 2\%. LARAMIE.}

Campeloma multilineata Meek \& Hajden. (Page 469.)

Fig. 1. Copy of Meek's original figure.

Fig. 2. Lateral view of a larger example, showing a slight angularity at the distal side of the larger volutions.

FIG. 3. Opposite view of the same.

Fig. 4. Lateral view of another example, having the angularity a little more dist inct.

FIG. 5. Lateral view of another example, having the angularity distinct and prominent.

Fig. 6. Fragment showing the aperture, and prominent angularity.

Fig. 7. Lateral view of an example from Crow Creek, Colorado.

Figs. 2-6 are from the valley of the Yellowstone, Montana. (All natural size.)

\section{Campeloma vetula M. \& H. (Page 469.)}

Frg. 8. Lateral view of the type specimen of Meek \& Hayden.

Fig. 9. Opposite view of the same, natural size.

\section{Viviparus leai M. \& H. (Page 467.)}

Fig. 10. Lateral view of a large example.

Fig. 11. Opposite view of the same.

Fig. 12. Lateral view of another example.

Frg. 13. Opposite view of the same.

Fig. 14. Lateral view of another example, a little more elongated than usual. (All-natural size.)

Campeloma multistriata M. \& H. (Page 469.)

Frg. 15. Copy of Meek's original figure.

Planorbis convolutus M. \& H. (Page 447.)

Frg. 16. Upper, under, and peripheral views of the type specimen of Meek \& Hayden. After Meek.

Planorbis (Bathyomphalus) planoconvixus M. \& H. (Page 447.)

FIG. 17. Upper view of the type specimen of Meek \& Hayden, natural size.

Fig. 18. Peripheral view of the same. After Meek.

Planorbis (Bathyomphalus) amplexus M. \& H. (Page 447.)

Fig. 19. Upper view of the type specimen of Meek \& Hayden, natural size.

Fig. 20. Under view of the same, enlarged. After Meek.

Planorbis (Bathyompinalus) kanabensis White. (Page 44\%)

Frg. 21. Upper view, natural size.

FIG. 22. Under view of the same example.

FIG. 23. Peripheral view of the same example.

Valdata? montanaensis Meek. (Page 470.)

Fig. 24. Outline views, enlarged. After Meek.

Valvata subuimilicata M. \& H. (Page 470.)

Fig. 25. Upper and nuder views of the type-specimen of Meek \& Hayden, natural size. After Meek. 


\section{Hyalina? evansi Meek \& Hayden. (Page 45\%.)}

Fig. 26. Outline views, enlarged. After Meek.

\section{Hyalina? occidentalis M. \& H. (Page 452.)}

IIG. 27. Upper, under, and peripheral views of the type-specimen of Meek \& Hayden. After Meek.

\section{Helix? vetusta M. \& H. (Pago 454.)}

FiG. 28. Apertural and opposite views of the type-specimen of Meek \& Hayden; natural size. After Meek.

\section{Helix evanstonensis White. (Page 454.)}

Fig. 29. Lateral view, enlarged.

FrG. 30. Opposite view of the same example.

FIG. 31. Under view of the same example.

Vitrina obliqua M. \& H. (Page 452.)

Fig. 32. Lateral view of type specimen of Meek \& Hayden, natural size.

Fig. 33. Apical view of the same. After Meek.

Goniobasis ? subtortuosa M. \& H. (Page 463.)

FIG. 34. Apertural and opposite views of the type specimen of Meek \& Hayden, natural size. After Meek.

\section{Hydrobia utahensis W. (Page 466.)}

Fig. 35. Lateral view, enlarged.

\section{Hydrobia subconica Meek. (Page 465.)}

FIG. 36. Outline lateral view, enlarged; copy of Meek's original figure.

\section{Hydrobia? eulimoides M. (Page 465.)}

FIG. 37. Outline lateral view, enlarged; copy of Meek's original figure.

$$
\text { Hydrobia recta W. (Page 466.) }
$$

FIG. 38. Lateral views of two fragments, enlarged.

\section{Hydrobia anthonyi M. \& H. (Page 465.)}

Fig. 39. Lateral view, natural size and enlarged. After Meek.

$$
\text { Hydrobia warrevana M. \& H. (Page 465.) }
$$

Frg. 40. Lateral view, natural sizo and enlarged. After Meek. 


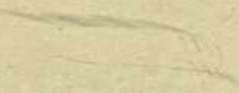


PLA'TE 28. EOCENE.

Unio chnopisthus White. (Page 434.)

FrG. 1. Left side view, natural size.

Fig. 2. Dorsal view of the same.

\section{Unio shoshonensis W. (Page 435.)}

FrG. 3. Left side view, natural size.

\section{Unio haydeyi Meek. (Page 435.)}

Fí. 4. Right side view, natural size.

Fig. 5. Left side view of a smaller example.

Unio washakiensis M. (Page 435.)

Fig. 6. Left side view, natural size.

FrG. 7. Right side view of a sandstone cast.

- Fig. 8. Interior view of a fragment of a right valve.

Unio tellinoides Hall. (Page 435.)

Frg. 9. Copy of Hall's original figure.

\section{Planorbis (Gyraulus) militaris W. (Page 447.)}

Fig. 10. Upper view, enlarged.

Fig. 11. Under view of the same example.

BXthinella gregaria M. (Page 466.)

Frg. 12. Lateral view, enlarged.

Fig. 13. Opposite view of the same.

Bulmus floridanus Conrad. (Page 454.)

Fig. 14. Copy of Conrad's original figure.

Melania claibornensis Heilprin. (Page 460.)

Fig. 15. Lateral view, much enlarged, together with an outline of natural size. After Heilprin. 

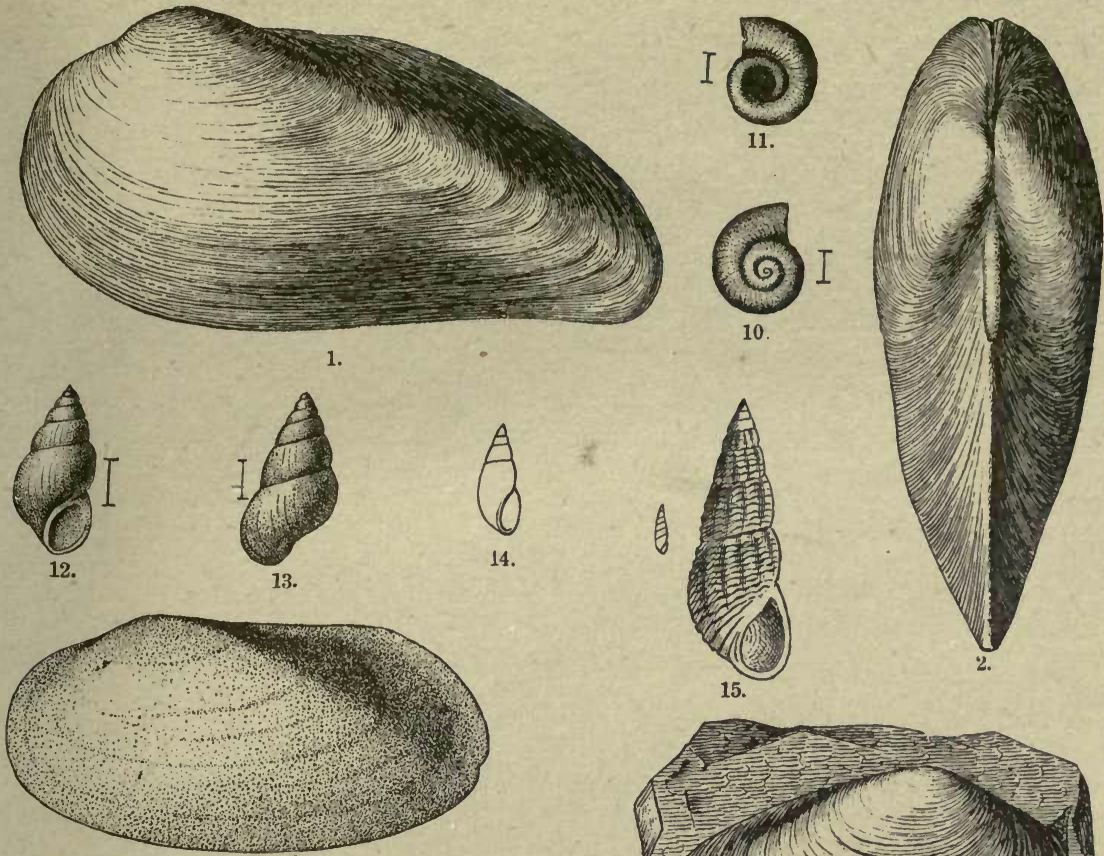

15.
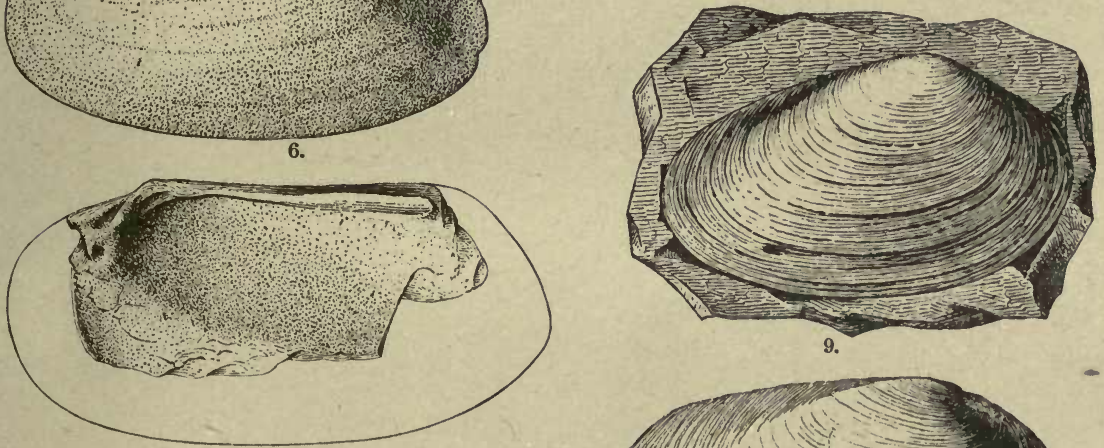

8.
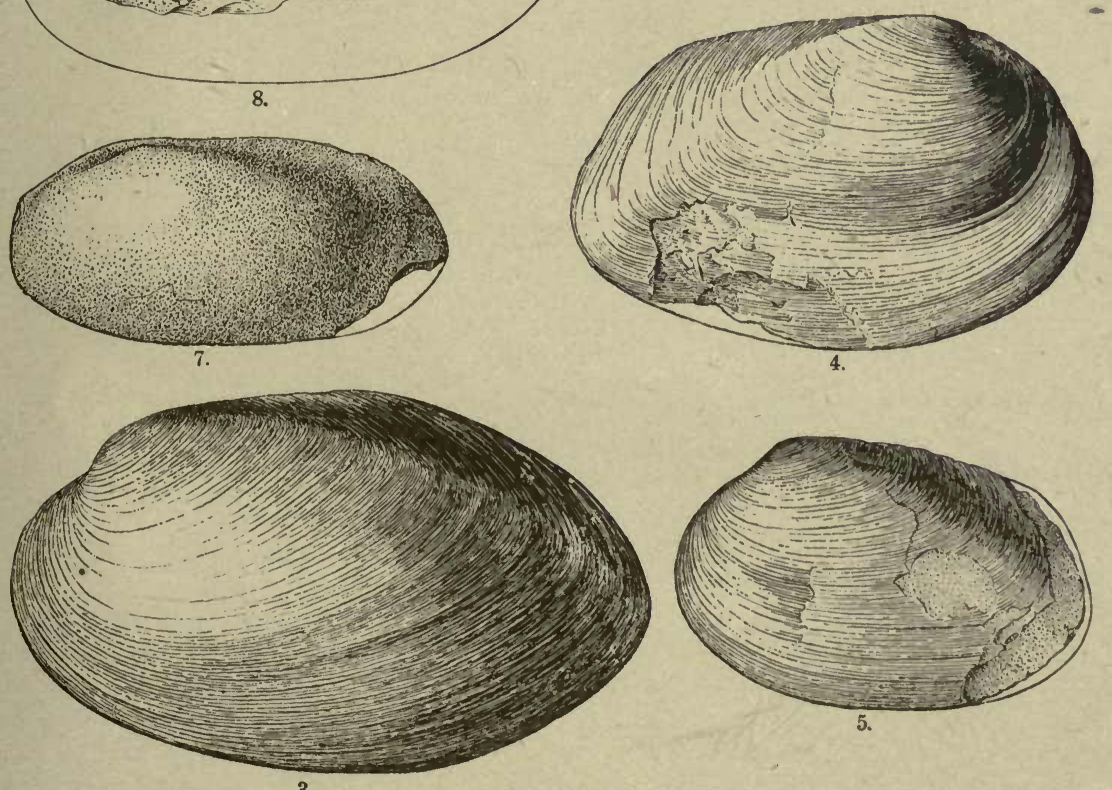

EOCENE. 



\section{PLATE 29. EOCENE.}

\section{Planorbis utahrasis Meek. (Page 447.)}

FIG. 1. Upper view, natural size.

FIG. 2. Under view of the same example.

Fig. 3. Peripheral view of the same. After Meek.

Planorbis utahexsis var. spectabilis M. (Page 447.)

Fig. 4. Upper view, natural size.

Fig. 5. Under view of the same example.

Fig. 6. Peripheral outline of the same. After Meek.

Planorbis cirratus White. (Page 448.)

Fig. 7. Upper, under, and peripheral views, enlarged.

Planorbis aqualis W. (Page 448.)

FIGs. 8 and 9. Under and peripheral views, enlarged.

Fig. 10. Upper view of a smaller example, enlarged.

(All are imperfect, and perfect adult examples are doubtless larger.)

Helix peripheria W. (Page 455.)

Fig. 11. Lateral view, natural size:

Fig.12. Opposite vier of the same.

Helix RIParia W. (Page 455.)

FIG. 13. Lateral view, natural size.

Fig. 14. Opposite view of the same example.

Pupa incolata W. (Page 456.)

Fig. 15. Lateral view, enlarged.

Fig. 16. Opposite view of the same example, showing the aperture.

FIG. 17. View of the same, showing the edge of the outer lip.

Pupa atavuncura W. (Page 456.)

Frg. 18. Lateral view, enlarged.

Pupa arenula W. (Page 50 456.)

FIG. 19. Two lateral views of the type specimen. The rim of the aperture has been broken off.

LimNate similis M. (Page 445.)

Fig. 20. Lateral view, enlarged.

FIG. 21. Opposite view of tho same. After Meek.

Limena vetusta M. (Page 445.)

FIG. 22. Lateral view, natural size.

Fig. 23. Opposite view of another example, a little enlarged. After Meek.

Limndea minuscula W. (Page 446.)

Fig. 24. Lateral view, enlarged.

Fig. 25. Opposite view of the same example.

Succinea (Bisachyspira) papillispira W. (Page 457.)

FIG. 26. Three views of separate examples, natural size, from gutta-percha casts in natural molds.

Axodonta decurtata Conrad. (Page 479.)

Fic. 27. Lateral view, natural size, from an example believed to have been Conrad's type specimen.

FIG. 28. Dorsal view of the same. The true geological age of this species is not certainly known, but it is believed to be Eocene. 
U.S. GEOLOGICAL SURVEY

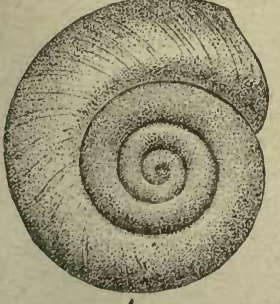

4.

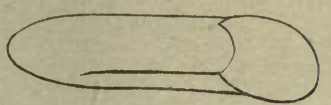

6.
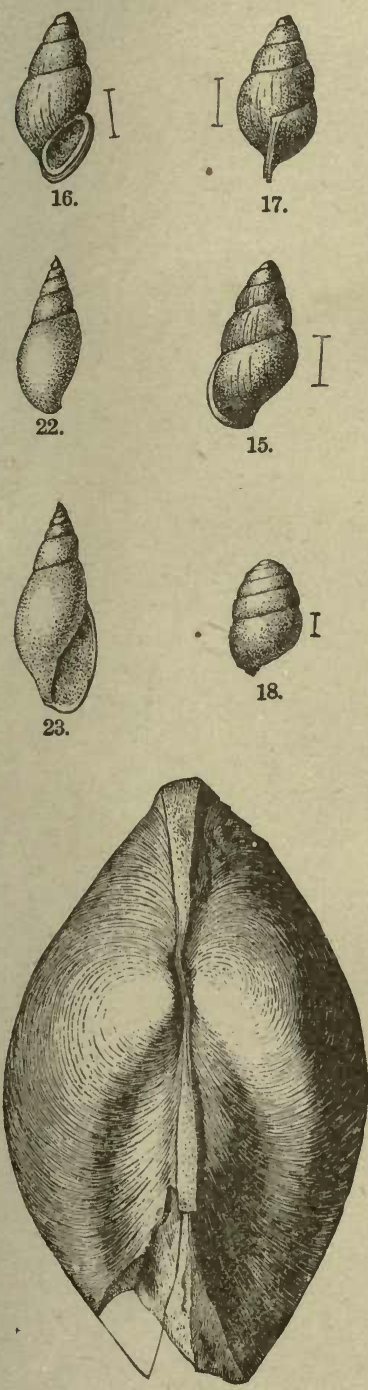

28.

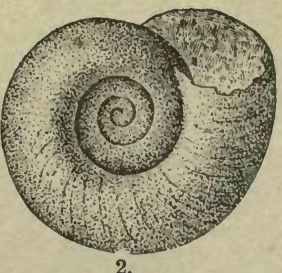

2.
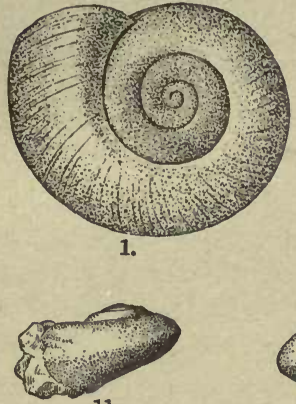

11.

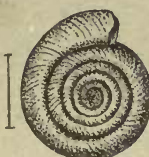

$\mathrm{T}$

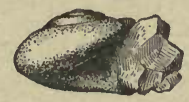

12.

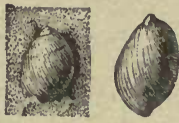

26.

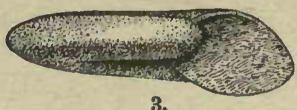

3.
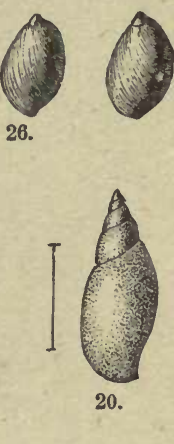

7.
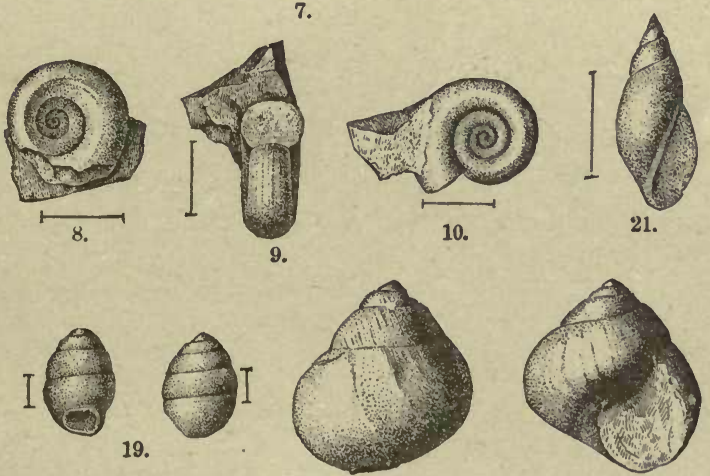

13.

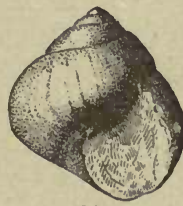

14.

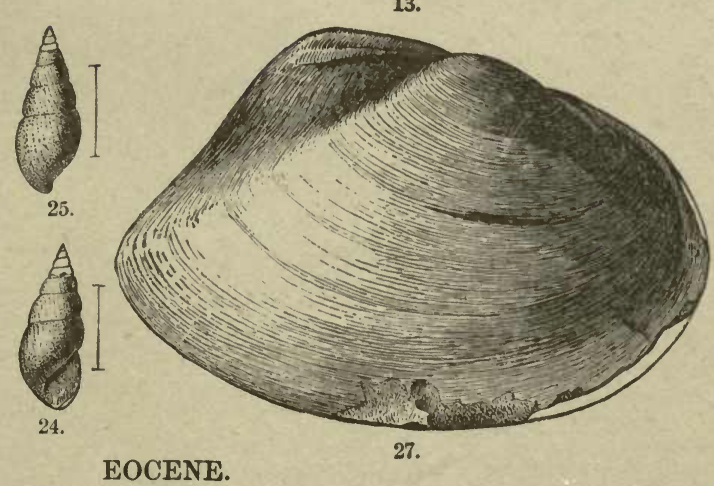

EOCENE.
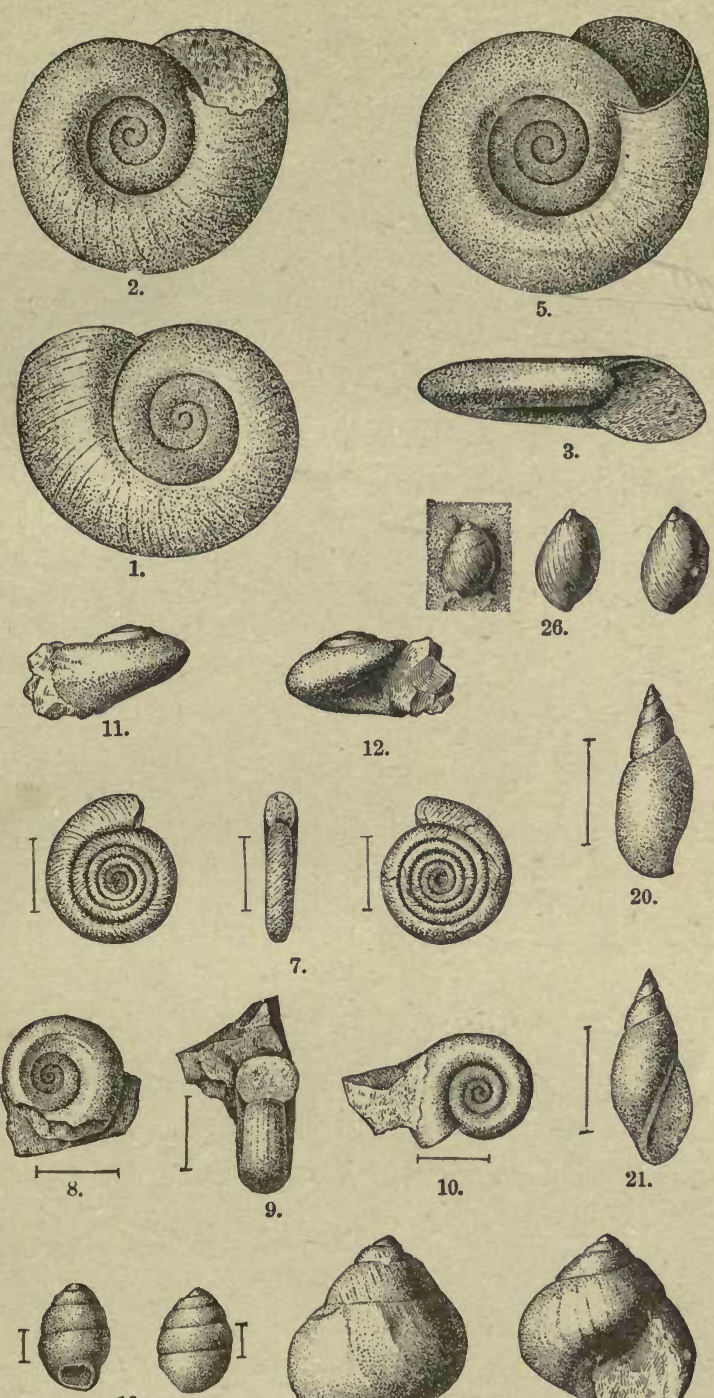

19. 

35 G 
PLATE 30. EOCENE.

Macrocyclis spatiosa Meek \& Hayden. (Page 452.)

Fig. 1. Upper view, natural size.

Fig. 2. Lateral view of the same example.

Fig. 3. Under view of the same, all natural size. After Meek.

Helix ? veterna M. \& H. (Page 454.).

Figs. 4 and 5. Copies of Meek's outline figures.

Physa Pleronatis White. (Page 450.)

Fig. 6. Lateral view of type specimen.

Fig. 7. Opposite view of a larger example, a little distorted, probably belonging to this species.

Fig. 8. Fragment of a very large example, believed to belong to this species.

(All natural size.)

Physa Bridgerensis Meek. (Page 450.)

FrG. 9. Lateral view, natural size.

Fig. 10. Opposite view of a more robust example.

Viviparus paludinaformis Hall. (Page 468.)

Fig. 11. Lateral view, natural size.

FiG. 12. Opposite view of the same.

Viviparus womingensis M. (Page 468.)

Fig. 13. Lateral view, natural size.

Fig. 14. Opposite view of the same. 
U. S. GEOLOGICAL SURVEY
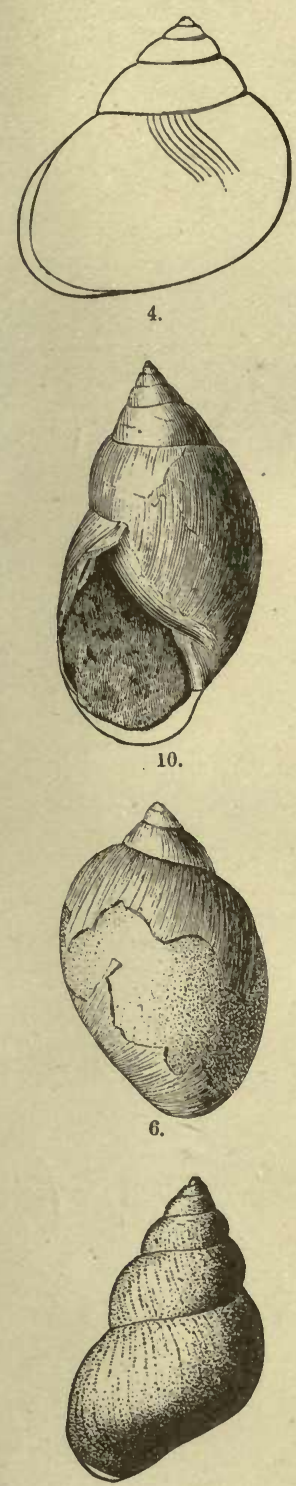

11.

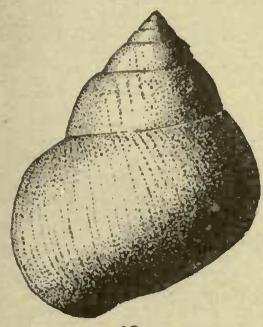

13.
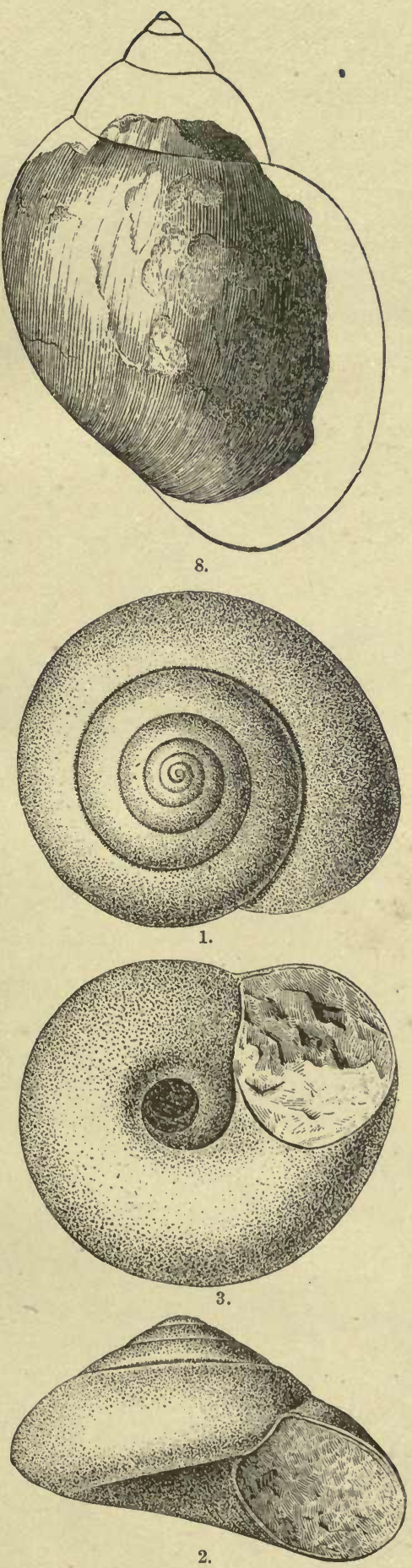

2.

EOCENE.
ANNUAL REPORT 1882 Pl. 30

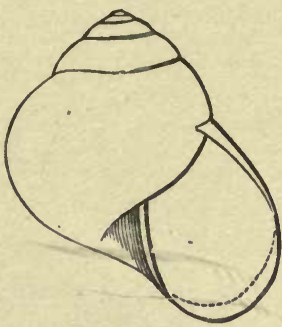

5.
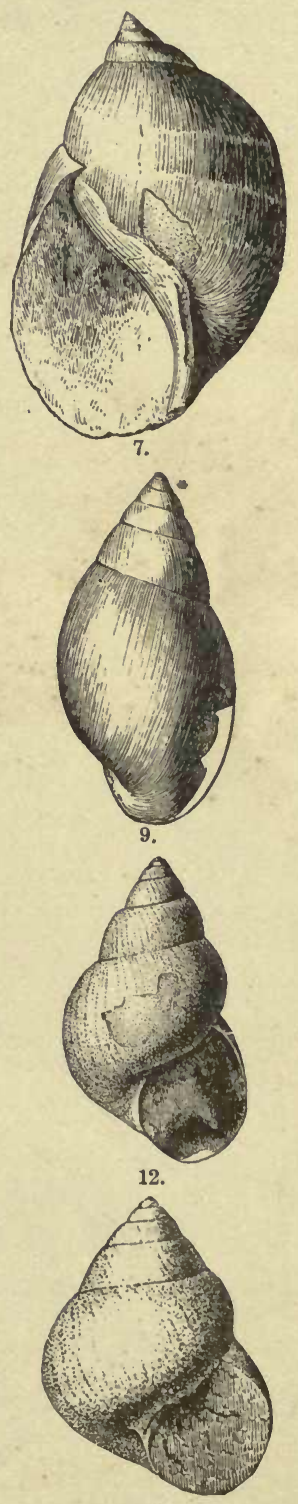

14. 



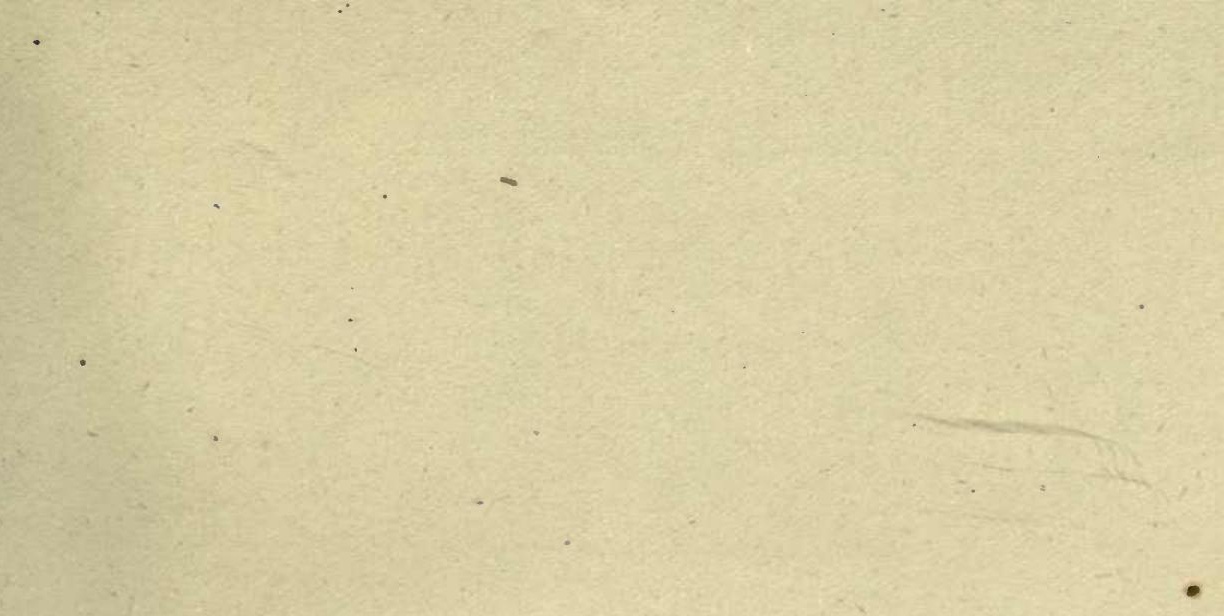


PLATE 31.

All the forms represented on this plate occur in the fresh-water Eocene deposits of Wyoming, Colorado, and Utah; and all are believed to be genetically related. They have been described by different authors ander six respective names, according to the variation of ornamentation and form. (See remarks on page 464.)

Figs. 1, 2, and 3 may be regarded as representing the Goniobasis simpsoni of Meek; Figs. 5, 10, 12, and others, G. tenera Hall; Figs. 14, 15, 20, and others, G. nodulifera Meek ; Figs. 19, 25, 28, and others, G. carteri Conrad; and Figs. 29 and 30, G. columinis White. Fig. 31 is a copy of Meek's figure of $G$. arcta, which he finally regarded as only a variety of his G. simpsoni. It, is however, very like a form which occurs in the Laramie beds of Bear River Valley in Southwestern Wyoming. 
U. S. GEOLOGICAL SURVEY
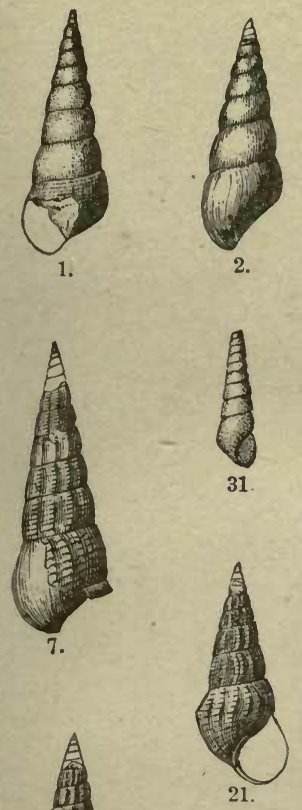

.
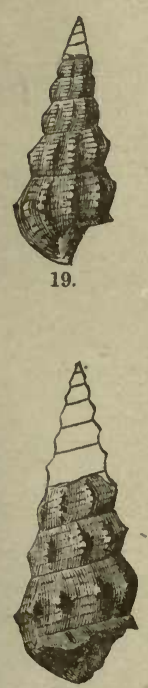

25.

20.
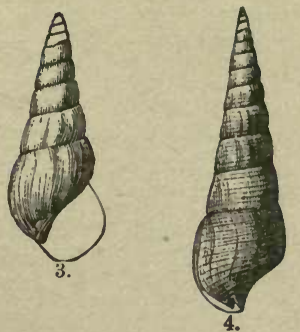

ANNOAL REPORT 1882 PL $\$ 1$
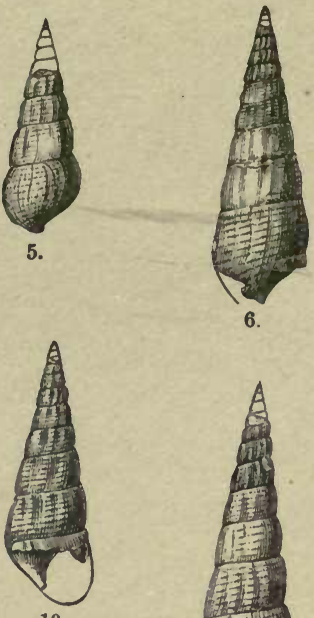

8.
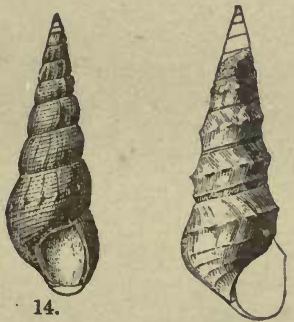

15.

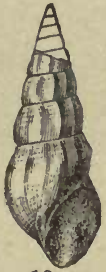

16.
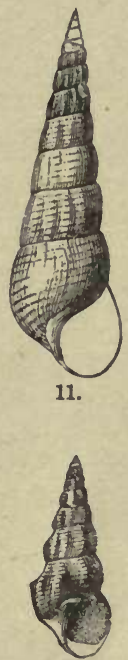

17.
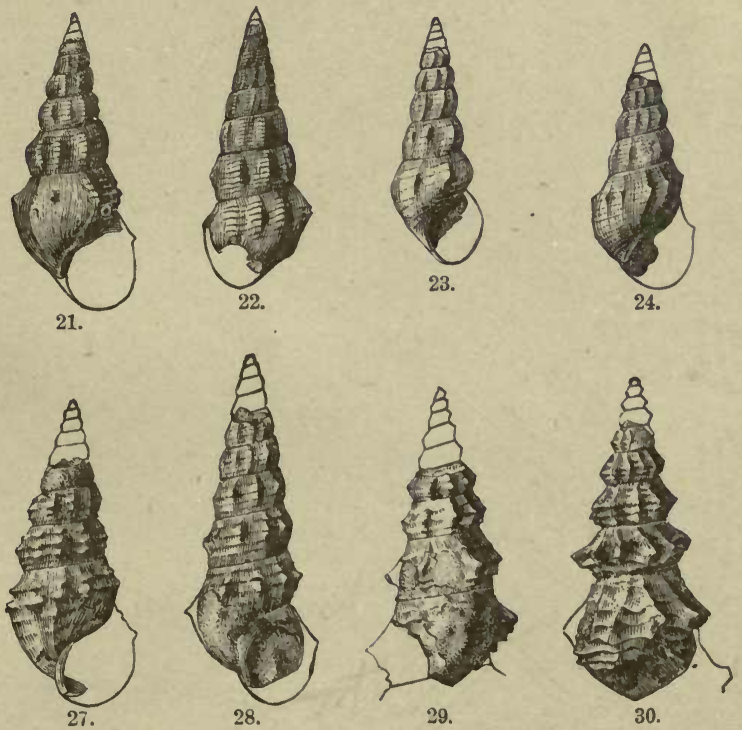

EOCENE. 




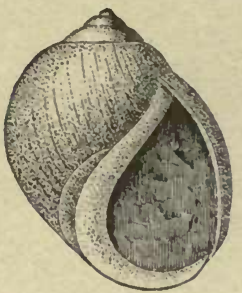

4.

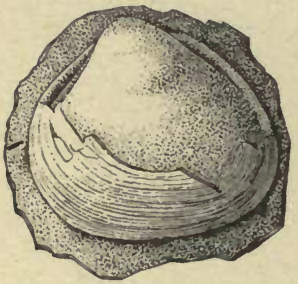

14.

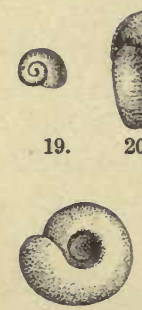

24.

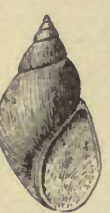

29.

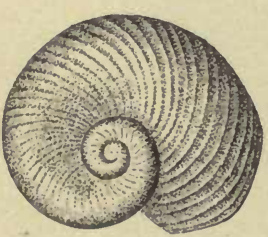

6.

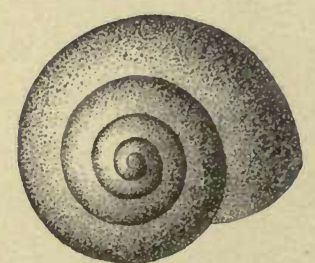

33.

21.

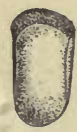

25.

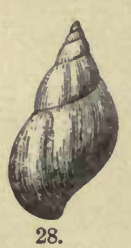

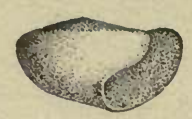

34.

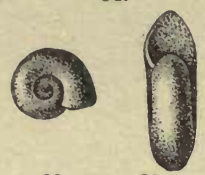

22.

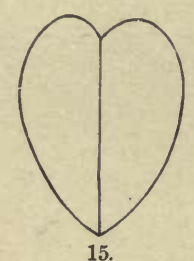

11.

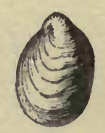

39.
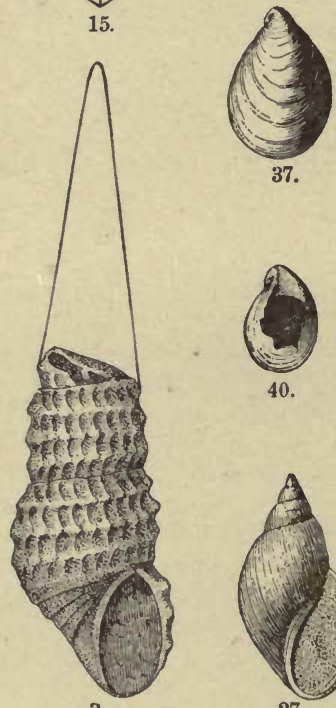

3.
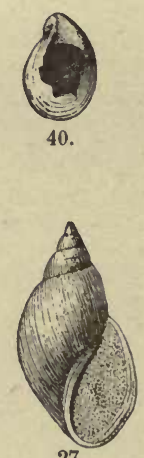

27.
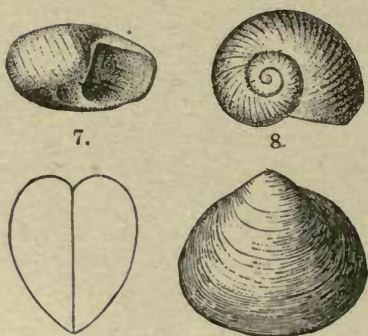

13.

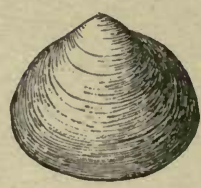

12.
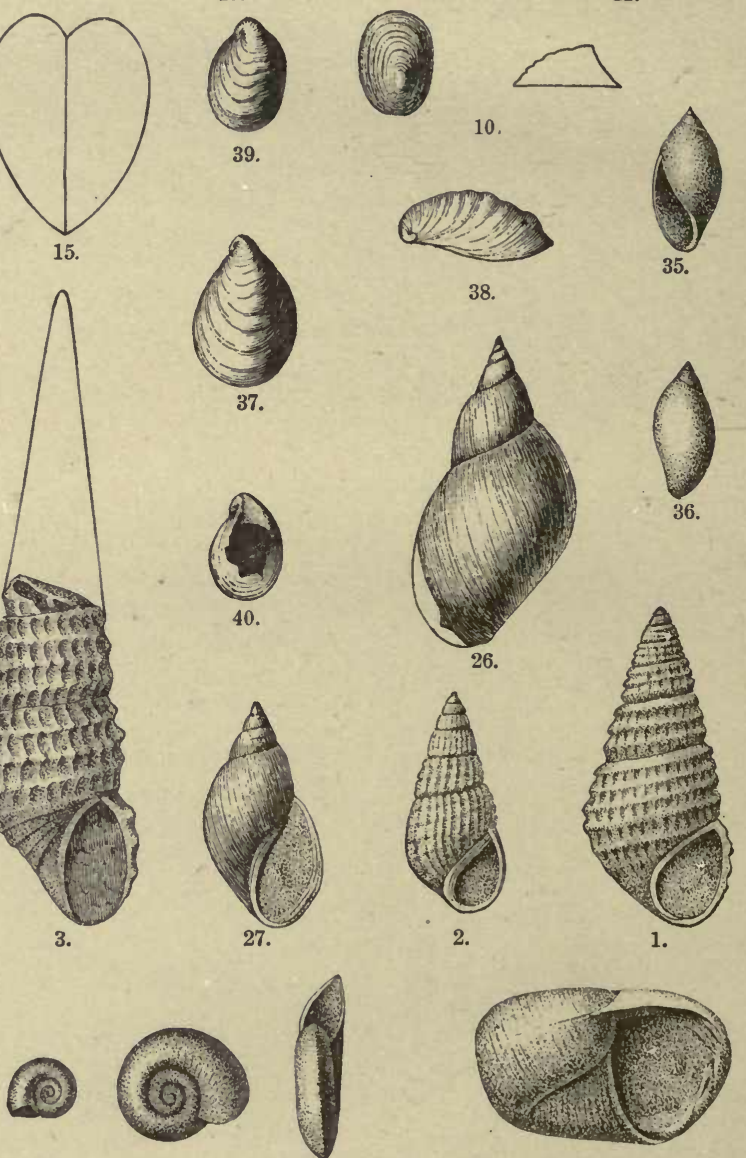

16.

17.

18.

5.
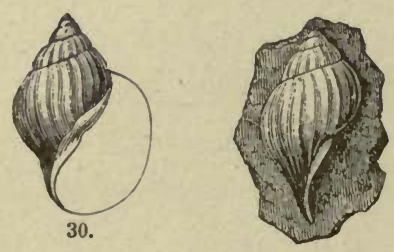

31.

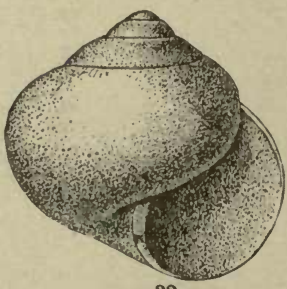

32.

MIOCENE AND PLIOCENE? 


\section{PLATE 32. MIOCENE AND PLIOCENE?}

Melania sculptilis Meek. (Page 461.)

Frg. 1. Lateral view, natural size. After Meek.

Melania subsculptilis M. (Page 461.)

Fig. 2. Lateral view, natural size. After Meek.

Melania tayloni Gabb. (Page 461.)

FrG. 3. Lateral view, natural size. After Gabb.

Litirasia antiqua G. (Page 465.)

Fig. 4. Lateral view, showing the aperture, natural size. $\Lambda$ fter Gabb.

Carinifex (Vorticifex) binneyi M. (Page 448.)

Frg. 5. Lateral view, natural size, showing the aperture.

Fig. 6. Upper view of the same example. After Meek.

\section{Carinifex (Vorticifex) tryoni M. (Page 448.)}

Fig. 7. Lateral view, natural size, showing the aperture.

Fig. 8. Upper view of the same example.

Fig. 9. Under view of the same. After Meek.

\section{Ancylus undulatus M. (Page 451.)}

Fig. 10. Upper view and lateral outline, natural size. After Meek.

Spharium rugosum M. (Page 440.)

Fig. 11. An example of not quite adult size, enlarged two diameters.

Fig. 12. A larger example, enlarged two diameters.

FIG. 13. Outline showing the convexity of the valves. After Meek.

Spharium Idahoense M. (Page 440.)

Fig. 14. An imperfect example, natural size.

Fig. 15. Outline showing the convexity of the valves. After Meek.

Planorbis vetustus Meek \& Hayden. (Pago 448.)

Frg. 16. Under view, natural size.

Fig. 17. Upper view of the same example, enlarged.

Frg. 18. Peripheral view of the saine, more eularged. After Meek.

Planoris leidyi M. \& H. (Page 448.)

Fig. 19. Upper view, natural size.

Fig. 20. Peripheral view of the same, enlarged, showing the aperture.

Fig. 21. Under view of the same, less enlarged. After Meek.

Planorbis nebrascensis Evans \& Shumard. (Page 448.)

Fig. 22. Upper view, natural size.

Fig. 23. Peripheral view of the same, enlarged. After Meek. 
Planoris lunata Conrad. (Page 448.)

Figs. 24 and 25. Copies of Conrad's original figures.

LimnaA Meeri Evans \& Shumard. (Page 446.)

Frg. 26. Lateral view of a large example, natural size.

Fig. 27. Opposite view of a smaller example. After Meek.

Limnea shumardi Meek \& Hajden. (Page 446.)

Fig. 28. Lateral view, natural size.

Frg. 29. Opposite view of the same. After Meek.

LimnaA (Polymitytis) Kingil Meek. (Page 446.)

Figs. 30 and 31. Copies of Meek's original figures, natural size.

Helix Leidyi Hall \& Meek. (Page 455.)

FIG. 32. Lateral view, natural size.

Fig. 33. Apical view of the same example. After Meek.

Helix (Zonites) marginicola C. (Pago 453.)

Fig. 34. Copy of Conrad's original figure.

Physa secalina E. \& S. (Page 450.)

Fig. 35. Lateral view, natural size.

Fig. 36. Opposite view of the same. After Meek.

Latia dalli White. (Page 451.)

Fig. 37. Dorsal view, natural size.

Fig. 38. Lateral view of the same example.

Fig. 39. Dorsal view of another example.

FIG, 40. Similar view of another example, showing a portion of the shell broken away, revealing the large lunate shelf extending forward from the beak. 


\section{NDEX.}

Abstract of report on geology of the Eureka District, Nov., by Arnold Hague.

Accompanying papers .................

Acid rucks of Kew eenaw Series, Origin of

Acrotreta gemma.

- prospectensis $.258,259,261$

Administrativo report of chiefs of divis. ions and heads of parties............... Affinitics of Hesperornis ................. Agassiz, $\Delta$ lexander, referred to.......... $A$ gate Bay group of the Keweenaw Series

- Minnesota

- Harbor, Keweenaw I'oint, Mich.......

Agnostus bidens .....................258, 259, 261

— communis ...................257, 258, 259, 261

- neon..........................258, 259, 261

- prolongus ..........................

- richmondensis .......................

- scclusus..............................

- tumidosus ..........................

- tumifrons ...........................

A gogrebic Lake, Mich............ 136, 147, 163, 165

Albany and Boston conglomerato ....... 114, 131

Algoma Mine, Canada .................

Alhambra Hills, Basalt of...............

Alloucz Mine, Mich....................

Alpha Peak, Altitude of ................

Altamont moraino................. 378, 388, 393

A merivan Muscum of Natural History,

Continued courtesies of the............

$\Delta$ mygdaloids of the Keweenaw Series de. scribed

Analyses of brino from Lake Lahontan

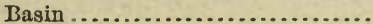

- - river water given by Bischof .......

- - tho water of Great Salt Lake.......

- - tufa from Lake Lahontan Basin.....

Anclyus undulatus

159

280

121

246

Ancylidae ............................

Andesitic pearlites, Position of ..........

Animikio group....................124, 135, 157

- -, Apparent thickness of, in Thunder Bay region.....................

- - at Grand Portage Bay, Minu........ 143, 157

- at Pokegama Falls, Minn ..........

_- Coarse gabbro dikes of, on PIgcon

Point and Thunder Bay ..........

- Dikes in tho ...................... 158, 160

_- Interbedded eruptives of ............. 158, 163

- in the Mesabi Range, Minn........ 161

- - Magnetitic beds of ..................

- on Pigeon Point.

141,15
Page.

Animikie group on the Kaministiqui: River, Canada ................ 158

_- - Saint Louis River, Minn...... 162

- - , Relation of, to Kewcenaw Series ... 135,

157,163

- -, Similarity of, to Penokee Huronian. $\quad 158$

- rocks of Gunflint Lake, Minn ......... i59, 161

Anodonta? angustata................. 424

- ? catskillensis........................ $4: 4$

- decurtata.......................... $\quad 479$

- parallela........................... 429

- propatoris ....................... $\quad 429$

- in Lake Lahontan Basin.............. 221

Anomia gryphorhynchus .............. 422

- micronema ......................... $\quad 242$

-propatoris .......................... 429

Anomiidæ ........................ 421

Anorthite in angite-andesite ............ 278

- rock of Keweenaw Series described... $\quad 97$

Antelope Hills..................... 388, 393

Anthracopupa ohioensis ................ 456

Apatornis .......................... 69

Apostle Islands, Wis ................. 133, 155

Archoeopteryx compared with Hesperor-

nis and Ichthyornis.................. \&3

Arethusina americana................. 250, 261

$\Delta$ rionillæ.......................... 452

Artesian water on the plains........... $\quad$ xvi

Asaphus gigas ...................... 20. 202

Åsar defined ......................... $\quad 299$

Ashbed diabaso of Keweenaw described. $\quad 108$

"Ashbed" of Kow eenaw Point, Mich .109, 119, 127

Assistants, chief, Mcnographs neally com-

pleted by the ......... $x$

,-- Work of the.................... xvil

Athyris subtilita...................... 269

Atlantic mine, Mich ...................

Atlas of the Enreka District........... 242

Atrypa Peak, Altitude of.............. 246

- - Devonian of ..................... $\quad 260$

Atrypa reticularis .................... $\quad 206$

Augite-andesite, Eureka District ....... 277, 280

$281,283,287,290$

- of Cliff Hills...................... 28.

_- Richmond Mountain ............... 278, 282

Augite-syenite described.............. 114

Auriculidx .......................... 443

Australia, Terraces on the coast of...... 207

Babylon Hills, Deronian limestone of.... 267

Bad River country, Wis...115, 119, 122, 130, 134, 136,

$174,177,180,183$

- gabbros, Relations of, to Huronian.. 135

- - region, Great thinning of rocks in .. $\quad 163$

- -, Wis., Coarse gabbros of........... 134 
Page.

Baptism River, Minn ...............127, 143, 145

- - , , Quartz-porphyry of ........... 127

Bare Hills of Keweenaw Point, Mich .... 130

Barrier, Description of a.............. $\quad 207$

Bars and embankments built by Lake

Labontan ....................... 210, 211

Barus, Dr. Carl, Important work under.

taken by

Basalt dikes in Richmond Mountain .....

—, Eureka District ..... $277,280,283,284,286,200$

- of Albambra Hills ....................

Basic flows of Keweenaw Series, Lateral extent of .

- rocks of Keweenaw Series, Chrono. logic relations of, to acid rocks of the same.

,---- Origin of

$---\ldots$, Proofs of contemporaneous formation of.

Basin of Lake Superior, Structure of the.

Basin Range Structure (Fig. 44)

-, The Great (See Great Basin).

Batchewanung Bay, Canada

Batt lo Islands, Canada.

Rayfield county, Wis

Beach ridges .

Bead Island, Canada,

Bearer Bay, Minn

Becker, G. F., Administrative report of.

Beds, Sedimentary, in Lake Lahontan ... 222, 224

Bell, R., on the Animikie gronp......... 160

-, , referred to................158, 162, 169, 171

Berg till............................. 297

Béte Grise Bay, Mich.............108, 140, 148, 152

Bien, Morris, Services performed by ..... 243

Bigsby, Dr., cited...................... $\quad 385$

Billings, E., eited ..................... $\quad 257$

Birds, Cretaceous; aquatic...............

-, Existing, without teeth..............

-, Geological horizon of .

- incapable of flight.

-, Oldest known........................

- , Origin of.

- related to reptiles .....................

-, Remains of, rare ....................

-, toothed, Classification of ..............

- with teeth, by Prof. O. C. Marsh........

- - Geological horizon of ............

Bisehof, Analyses of river water by .......

Black and Nipigon Bays, Canada, Rocks of peninsula between

- Bay, Canada ................... 129, 137, 176

- - , Thickness of Keweenawan rocks of

-River, Miclı...................... 152, 177

- , Wis .......................... 150

Bohemian Mountain, Mich ............ 105

- Range of Keweenaw Point, Mich ...93, 126, 139,

Bois Blanc Lake, Minn., Crystalline schists of ................................

Bonneville, Lake, Extent of .............

Bowlderets defined..................... Bowlders, Trains of .................... Brain growth, General law of ...........
Brain of Hesperornis

Page.

- Ichthyornis......................

Brine from Lake Lahontan Basin, Analyses

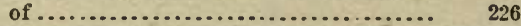

Brooks, T. B., referred to ............ 166, 171

Bruló Lake, Minn ..................... 186

- - region, Gabbro of................ 135

Brule River, Minn .................... 126, 144

- - - Felsites of .................. 144

Brunschweiler River, Wis ............. 133

Brush Peak, Devonian formations of ..... 266

Bnffalo Salt Works, Nov., Analysis of brine from ................. 226

- - - Description of the ........... 225, 226

- - - Production of the ........... 226

Bulimus floridanus.................... 454

Bulinus atavus ...................... $\quad 450$

-disjunctus......................... 451

-longiusculus........................ 451

- rhomboideus ..................... 451

- sublongatus ......................... $\quad 450$

Bull-whacker Mine, Quartz-porphyry dike

in ............................... 274

Burlington Bay, Miun................ 143

Bythinclla gregaria .................... 466

Calumet and Hecla Mine, Mich ......... 130, 180

Cambrian rocks, Thickness of, in Nevada. $\quad 254$

Campeloma macrospira ................ 469

-multilineata......................... 460

-multistriata....................... 469

-producta........................ 469

- vetula ............................. 469

Canaday, David, eited .................. $\quad 381$

Cape Choyyค, Lake Superior ........... $\quad 177$

- Garguntua, Lake Superior ........... $\quad 177$

Carbon Ridge and Spring Hill group ..... Carboniferous rocks of Eureka District..

Caribon Island, Lake Superior............

- -, Thunder Bay, Canada ..............

Carinifex (Vorticifex) binneyi.............

- - tryoni ...........................

Carlton's Peak, Minn. ... . . . . . . . . . . . . Carp Lake, Minn .....................

Carson and Humboldt Sink, Description of the ............................. Cascade River, Minn ....................

Cassiopella turricula...................

Cercocarpus lardifolius ...................

Ceriphasidiice .......................

Cerithiidoe me

459

(n).......

Chamberlin, Prof. T. C., Administrative report of ........................

___ Examination of glacial moraines by ..................... xvii, 17

- - - Preliminary paper on the terminal moraines of the Second

Glacial Epoch, by........... 291 xvii, 17

- - - referred to ........... 93, 139, 174, 175

Chaquamegon Bay, Wis................ 155

Chariocephalus tumifrons................ $\quad 258$

Chauvenet, W. M., referred to............ 126

Chemical deposits of Lake Lahontan .... 211

Chester, Prof. A. H., on the Mesalii Iron

Range, Minn .................. 161, 170

5

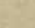

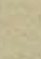

4
.

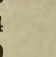

1

0
4

6

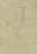

9

1


Chester, Prof. A. H., on the Vermillion

Lake region of Minnesota.............

Chief geologic assistants, Monographs nearly completed by the........

- - Work of the

Chippewa glacier.

Chonetes granulifera.

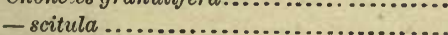

- verneuiliana .........................

Clark, E. A., Services performed by .......

Classification of toothed birds.............

Cliff Hills, A ugite-andesite of ............

Climate of the Great Basin ........... 196, 232

-, Quaternary, recorded by Lake Lahontan

Clinton Point, Wis .................... 155, 175

Cloquet River, Minn ................... 126, 142

Coarse gabbro of Keweenaw Series, Origin of

Coast moraines.........................

Colorado Platean region, Map of the ......

- - , Topographic material pertaining to the

- _ unrivaled for the study of impor. tant problems.

- - , Work in the

-, Work in

Columna teres

- vermicula.

Comb's Mountain, Devonian formations Commingling of Carboniferons fauna in

N. Mex., Col., and Utah.

Comparison of Hesperornis with Archoeop teryx

- Ichthyornis with Archoeopteryx......

Conchifera

Conglomerates of Kew eenaw Series deseribed

Conocephalites bellus.

- breviceps

- dissimilis

- laticeps

- linnarssoni

- pernasutus.

- prospectensis

Conrad, T. A., Description of fossil Uniones

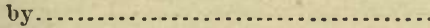

Cook, G. H., cited.................... 302, 345

Copper-bearing rocks of Lake Superior, by

R. D. Irving ............

- - - - Former studies of .......

- - - - - Obstacles to the study of.

Copper deposits of Lake Superior .........

- - Ontonagon region, Mich..........

- , Origin of ........................

- Harbor, Keweenaw Point .............131, 176

- in Saint Croix Valley, Wis ............

- in Wisconsin ........................

- mining in Michigan..................

- on Isle Royale

- - the Minnesota coast of Lake Superior

- Range, Douglas County, $W$ is........... - , South, Mich.

- Rules to guide explorers for, in Lake

Superior region

Corbicula augheyi

169

xvi
Page.

Corbicula berthoudi.

Page.

- cleburni.

- cytheriformis

- nebrascensis

- obesa

- occidentalis

- subelliptica ..........................

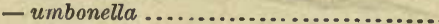

-(Leptesthes) cardinaformis .............

- fracta...........................

- macropistha.

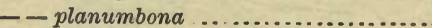

- (Veloritina) durkeei.....................

Corbula crassatteliformis .................

- englemanni

- mactriformis ........................

- perundata...................................

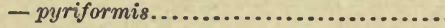

- subtrigonalis.........................

- tropidophora .........................

- undifera.............................

ar. subundifera

Corbulidæ ...........................

Cordaites in White Pine shale............

Coteau des prairies ......................

- du Missonri .........................

- gallatinensis..................... 258, 259,261

-granulosus....................... 259, 261

-larvicep8.......................... 258

- occidentalis......................... $\quad 258$

- similis............................ 258

- simulatus.......................... 259

- unisulcatus .................... 258, 259, 261

Cretaceous birds; aquatic.............. 85

Cross River, Minn ................... 143

Crystalline schists in the Lake Superior region of doubtful geological position

- - of Bois Blane Lake, Minn..........

- - Dog Lake, Canada

- - east shore of Lake Superior......

- - Rainy Lake ....................

- - Saganaga Lake..................

- - - the Marquette and Menominee regions, Mich................

Wisconsin River Valley........

- - -. Wisconsin

_- Vermillion Lake, Minn .......... 162, 169

Cupriferous amygdaloids of the Kewee.

naw Series........................ 181

- conglomerates of the Kew eenaw Series. $\quad 180$

- veins of the Keweenaw Series ......... 183

Current River, Thunder Bay, Canada.... 159

Currents, shore, Action of.............. 207, 208

Curtis, J. S., Work of.

Curve exhibiting the rise and fall of Lake

Lahontan (Fig. 51) ....................

Curves exhibiting the oscillations of La-

hontan climate (Figs. 55, 56) ...........

Oyrena carletoni.......................

Cyrenidær.......................... 435

Dacite, Eureka District........ 277, 280, 282, 284

Dakota, eastern, Topographic features of . $\quad 393$

-, - Moraines of..................... 394 
Page.

glacier. ......................

Dalles of Saint Croix River, Wis .........

Dana, J. D., cited.....................

Dawson, G. M., cited ............ 313,385, 398, 399

Davosonella meeki.......................

Dead Sea, Salinity of tho ..............

Deltas, Terrace.......................

Dendritic tufa in Lake Lahontan Basin .. 214, 215

Denver, Soils near, investigated ........

Deposits, Saline, of Lake Lahontau...... 224, 230

- Sedimentar 5 , in Lake Lahontan ......

- Tufa, of Lake Lahontau ..............

Description of Hesperomis.

- Ichthyornis

prodnets of Lake Lahontan..

Detrital rocks of Koweenaw Series ......

,---- , Origin of ...............

Devil's Track River, Minn..............

Deronian fossils in the Mackenzio River

Basin.

- rocks of Eureka District .............

Diabase-porphyrite of Keweenaw Series described.

Diabases of Kewcenaw Series described..

Diamond Monntains, Geology of .........

- Peak, Altitude of......................

- quartzito

- Range, Position of.................

- Valley.

Dicellocephalus angustifrons .............

- vilobatus ............................

- expansus.

- finalis ...............................

- flabellifer

- marica

-

- osceola.

- quadriceps

- richmondensis.

Dikes in the Keeweenaw Series..........

- of Animikio group on Pigeon Point, Minn..................

- - - - Thunder Bay .............

Director, Report of the.................

Dog Lake, Canada.

Dome, $t$ fa

Basin (Fig. 50) ......................

Domes and towers of tufa built by Lake

Lahontau ............................

Douglas Connty, WV is .....137, 155, 156, 174, 176, 179

- - Copper of......................

Douglas Houghton River, Kewcenaw Point

Drift, Classification of ................

- features of eastern Dakota ...... .....

-, shore, Naturo of .....................

Driftless area ........................

Duluth beds of Kewcenaw Serics ........

-, Minn., Coarse gabbro of ..............

- , Rocks of $105,110,114,119,124,134,142,175,185$

Dwight, IV. B, cited .

Eagle Harbor, Koweenaw Point, Mich..

- Mountain, Miuu., Augite-syenite of ...

- Salt Works, Nev., Analysis of brine

from $\ldots . . . . . . . . . . . . . .$.
Eagle Salt Works, Nev., description of the

- - - Profile of reservoir and vats at ,--- Yicld of

Kast Humboldt Mountains..............

- shoro of Lako Superior, Crystalliuo schists of.................

- - - - Keweenawan rocks of.....

Easteru sandstono betwcen Bêto Griso Bay and Lake A gogebie .... ..... - - Different views as to its relation to the Kowcenaw Series ..............

- - east of Keweenaw Bay ...........

- -, Former supposed Triassic age of .

- Geologic position of ...........

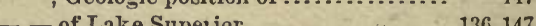

— - on Kewecnaw Point.............. 147

- - Phcnomena of coutact of, with Kewcenawan rocks .............. 148

- -, Quarry in, on tho Torch Lako Railroad .......................... 151

- Relations of, to Keweenawan rocks 152

- - - - Series ................ 147

Embankments, shore, Ideal plat illustrating (Fig. 46) .................. 207

- -, The formation of ................ 206

Emmons, S. F., Administrative report of.. 22

- - cited ....................... 257, 265

- - Work of ..................... xvi

Englacial till defined . . . . . . . . . . . . . . $\quad 397$

Eolian deposits........................ 304

Erie glacier, Western Moraine of........ $\quad 330$

Eskers defined ......................... 299

Euomphalus subrugosus ................ 269

Enreka district, Cambrian rocks of ...... 254

- -, Carboniferous rocks of ........... 268

- -, Climate of ....................... 246

— Devonian rocks of . . .............. 264

—-, Diamond Peak, Quartzitı of ...... 253, 268

- -, Eureka quartzito of .............. 253, 262

_ Hamburg limestone of . . . . . . . . . 253, 255

-,- - shale of ....................... 253, 255

- - Geologic work in................ xvi

- - Geologic sections in .............. $\quad 288$

- -, Granite of....................... 273

- -, Granite porphyry of ............. 274

- - Lone Mount limest one of ......... 253, 262

_-, Lower coal-measures of ............ 253, 268

_. Mode of occurrence of volcanic rocks in .......................... 280

- - Nevada limestone of ............. 253, 264

- - Paleozoic formations of ........... 248

,--- section of.................... 251, 253

- -, Pogonip limestone of. ............ 253, 260

- , Position of ...................... 244

- - Pro-Tertiary igneous rocks of..... $\quad 273$

_ - Prospect Mountain limestone of.... $\quad 253$

,--- quartzite of................ 253

- -, Quartz porplyyry.................. 273

- - Relative age of rolcanic rocks of ... $\quad 281$

- - Secret Cañon shale of............ 253, $25 j$

- $\rightarrow$, Silurian rocks of................. 260

-, Tertiary and post-Tertiary volcauic rocks of ...................... 277

_- Upper coal-measures of........... 253, 270

227 - Weber conglomerato of........... 253,270 
Page.

Euroka district, White Pine shale of ..... 253, 266

- Mining district, Development of .......

- quartzito

Exchange of publieations provided for by

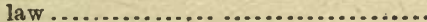

Existing birds without teeth.

Fault on Keweenaw Point, Micb.........

-, The Keweenaw ......................

Faulting, Recent, in the Great Basin ....

Faults at Poreupino Mountains, Mich ...

- in Douglas County, Wis

- on Lake Superior.

Feet of Hesperornis

- Ichthyornis

Felsite of Cascado Pirer, Minn

- Devil's Track River, Minn

- Mt. Iloughton, Keweenaw Point, Mich

Felsitic porphyries of Koweenaw Sories describod

Fenestella (Sp. १)

Field work, Synopsis of .................

Financial statement for the fiscal year...

Finger Lako glacior.

Fish Creek Mountains ..................

- Valley

Floe till defined

Flowage, Indications of in basic rocks of

Kewcenaw Series ....................

Fluidal structure in amygdaloids of $\mathrm{Ke}$. weenaw Series .

- texturo in guartz-porphyry of Keweenaw Series

Fond dn Lac, Minn , Sandstone of

Forest beds.

Fort Wingate, N. Mex., Base line measured near ...........................

Fossil lakes, Discovery of, in Nevada, California, and Oregon ............... - , The smaller, of the Great Basin .... - plants collected by L. F. Ward ......... Fossils, invertebrate, Collection of, by Dr.

C. A. White ....................... xvi

Foster and Whitney referrod to......... 130, 148, $149,152,174,180,182$

Fourteun Mile Point, Lake Superior .....

Fronch River, Minn .................117, 142, 188

Gabbro, Coarse, of Duluth, Minu ....... 134

Gabbros of Keweenaw Series described.. 102, 104

Garnet in rbrolite.................... 279

Gary woraine ......................378, 388, 393

Gasteropod shells in Lako Lahontan doposits....................213, 221, 223

Gasteropoda .........................

Gaylussite in Lake Lahontan Basin .....

Gedles and Bertrand Mine, Rhyolite of..

Grikie, James, cited

Grecorallaw of brain growth

Genes glacior Mlornine of ..............

Geograplic distribution of Deronianfauna Guroka District.

Geologic differences between augite-andesite and basalt.

- hurizon of Odontornithes ..............
Georgia sates of Vermont

Gilber t, G. K , Administrative report of .. 14

- - cited respecting drift.......331, 333, 335, 338

_- - Paper on Lake Lahontan revised and edited by ................. 195

- - roferred to ...................... 131

- - suggests how salt lakes may be. come fresh without overflowing. 199, 229

Glacial corrasion ................... $\quad 355$

- epoch, second, Terminal moraine of ... 291

- movements in Dakota .............. 389

- - the Finger Lako region......... $\quad 358$

- - - Grand River region ........... $\quad 342$

- - - Green Bay reglon ............. $\quad 318$

- - Hudson Valley region......... 373

- - Lake Michigan rogiou ......... $\quad \mathbf{3 2 5}$

- - - Lake Superior region ......... $\quad 387$

- - Maumee region ................ 333

- - Mohawk region .............. 361

- - - Miunesota region ............ 392

- - - Saginaw region ............. $\quad 330$

- - - Scioto region............... $\quad 340$

- , Law of ...................... $\quad 320$

Gneiss of Lake Superior region .......... 168

- Thunder Bay, Canada ............ 161

Golden, Colo., Geology of tho vicinity of.

Goniobasis arcta ....................... 464

- carteri.......................... 464

- chrysalis.......................... $46^{2}$

- chrysalloidea ..................... 462

- cleburni ........................... 462

-columinis .......................... 464

- convexa ........................... 463

- - var. impressa..................... 463

- endlichi ......................... 403

-gracilenta ........................ 463

-invenusta.......................... 463

-macilenta........................ 462

- nebrascensis ....................... 463

- nodulifera........................ 464

- omitta.......................... 463

- simpsoni. ......................... 464

- sublacvis ....................... 463

- subtortuosa. .................... 403

-tenera ........................... 464

- tenuicarinata.................... 403

Gore, J. Howard, $\Delta$ dministrative report of $\quad 30$

Goose Point, Thunder Bay, Canarla ...... $\quad 159$

Grand Marais, Minn ...............123, 144, 177

- Portage Bay, Minn.... ..... . 135, 141, 143, 157

- - - Animikie slates of .......... 143, 157

- - Dikes of ................... 141

- River glacier ........................ 341

- Traverso glacier.................... $\quad 326$

Granite, Eureka District ............... 273

- of Keweenaw Series described ........ 114

Granite-porplyry, Age of .............. 274

- Composition of ................... 275

- - Eureka District................. 274

Granitell of Kereenaw Series described 114

Granitic porphyry of Kewecnaw Series described ......................... 114

284 Graptalites in Pugonip limestone......... 261

50 Gratiot River, Keweenaw Point, Mich. 119, 139, 149 
Page.

Great Basin, the, Altitude of........... 196

- - Barrenness of ................ 196, 199

- - Climate of..................... 196, 232

- - Description of ................ 196

- - , Form of ......................

- - , Geologic attractireness of ..........

- - Industries of ..................

- - Lakes of ..................... 197, 201

- - , Mountains of ....................... 196, 200, 202

- - Oases in .................... 199

_- Present orographic movements in. $\quad 232$

- - Q Quaternary climate of .......... 231

- - Rainfall of.................. 196, 199

- - Rivers of ..................... 197

—- Scenery of...................... 196, 199

- - Seasons in .................... 200

- - Size of ...................... 196

_ - Storms in the uplands of ........ 200

- - , The smaller fossil lakes of...... $\quad 234$

- - Topography of ................ 196

- - Vallegs of .................. 197, 202

- - ; why so called ................. 196

Great Palisales of the Minnesota coast 105. 113, 114

- -, Quartz-porphyry of the ........... 126

- - Relations of acid and basic rocks at. $\quad 126$

- Salt Lake, Analyses of the water of... 212

Green Bay glacier....................

Greenstone group, The, of Keweenaw

Point ..........................

-, The, of Keweenaw Point .......121, 131, 183, 186

Gros Cap, Lake Superior.............. $\quad 178$

Growth, brain, General law of ......... 57

Gunflint Lake, Minn ................. 159, 161

Habits of Hesperornis..................

- Ichthyornis ......................

Hague, Arnold, Abstract report on Geology of tho Eureka District, Ner., by

_ Administrative report of ............

- Work of ..........................

Halysites.

Hamburg limestone ...................

- shale .............................

Helicida . ...........................

Helix evanstonensis

- kanabensis........................

- leidyi...............................

- peripheria ..........................

- riparia...

- I veterna

- ivetusta ...........................

- (Zonites) marginicoli

Hesperornis, Affinities of................

-, Brain of...........................

- Comparison of, with Archoeopteryx ...

-, Description of .....................

-, Habits of ............................

,- Legs and feet of....................

-, Locomotion of .....................

-, Origin of peculiar features of .........

-, Pelvie arch of .......................

-, Reptilian ancestry of ................

-, Restoration of ......................

-, Ribs of.

-, Scapular arch of ...................
Hesperornis, Size of

- , Tail of ........................... 61

-, Teeth of ....................... 52

-; Vertebrid of......................... $\quad 57$

- Wings of ........................ 59

Highland Range, Age of .............. $\quad 250$

History, Sketch of the geologic, of Lake

Lahontan ....................... 195

Hitcheock, C. H..................... 306

Hoosac fault ........................ 288

- -, Volcanic rocks of ................ $\quad 280$

Hornblende-anclesite, Eureka District ... 277, 280

Hornblende-gabbro of Keweenaw Series deseribed ......................... 105

Hornitos Cone, Geology of ............. 284

Hot Springs associated with lines of recent faulting in the Great Basin ....... $\quad 232$

- -, Tufa deposits of................. $\quad 219$

Houghton, Douglas, referred to ......... 148

- Mount, Keweenaw Puint, Mieh ...... 130

House Range, Pogonip limestone of...... 261

Howell, E. E., cited ................... 256

Hudson Valley moraine.............. 366

Hungarian River, Keweenaw Point...... 149, 154

Hunt, T. S., on the Animikio gronp ...... 162

- - - referred to ................124, 135, 162

Huron Bay, Lake Superior............. 147, 177

Huronian (Animikie group)..... 124, 135, 141, 143,

- Comparison of basic eruptives of the, with those of the Keweenaw Series.

-, Confnsed use of the term .............

- of the Marquette and Menomince regions of Michigan ...........

- - Penokee region, Wisconsin ......

-, Relations of the, in general to tho Ko. weenaw Series ................... 171

-, Relations of the, to synclinal ........ 175, 179

- The original ...................... 163

- - Eruptives of ................. 164

- - , Relations of, to the Animikie group .................. 164

Hyalina ? evansi ..................... 452

-1 occidentalis......................... 470

Hydrobia anthonyi .................. 465 .

- Peulimoides........................ 465

- recta.......................... 466

- subconica....................... 465

- utahensis ........................... 466

-warrenana....................... 465

Hyolites primordiaiis .................. 258, 259

Ichthyornis, Brain of ............... 71

-, Comparison of, with A rchoeopteryx ... $\quad 83$

-, Description of .................. 69

-, Habits of ........................ 82

-, Legs and feet of .................. 77

-, Pelvic arch of ................... $\quad 75$

-, Reptilian feat ures of ................ 79

- , Restoration of ................... 77

-, Scapular arch of .................. $\quad 73$

-, Skull of.......................... $\quad 70$

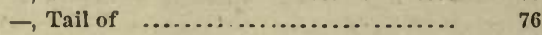

-, Teeth of ........................... 71

-, Vertobra of ..................... 73 
Ichthyornis, Wings ot $242,278,285$

Iddings, Joseph P., cited ...............242, reka District, by .................

Illustrations, List of .

Interlobate moraines defined.

_- described...315, 323, 328, 330, 339, 341, 351, 373 , $380,382,384,397$

Intermediate moraines. (See Interlobate moraines.)

Investigations initiated

Iphidea depressa

Irving, R. D., cited in respect to terminal moraines

- - on copper-bearing rocks of Lake Superior.

Isbister, A. K., cited

Isle Royale, Mich. ...........

- - Copper on .......................

_- Relation of rocks of, to rocks of Minnesota coast.

_ of .............................

Juniperus occidentalis..................

Kakabika Falls, Canada

Kames dlfined .......................

Kaministiquia River, Canada........... 158, 159

- - Animikio group on..............

Kanab Cañon, Paleozoic section of ........

Kettle moraine synonymous with term. inal moraine of the second glacial epoch.

- Range........

- River, Minn

Kettles................................

$\mathbf{x V}$

258

316

89

265

7,183

188

141

137

246

159

299

158

272

291

321

187

311

Keweenaw Bay ..................140, 147, 148, 177 - Fault ........................139, 154, 155 —-, Foster and Whitney's riew as to ...

- Point, Mich........................114, 115, $117,119,121,123,130,136,139,174$ - - A shbed of.. $109,119,127$

_. Bare Hills of 139

- - Bohemian Range of ........93, 126, 139, 153

- - Eastern sandstone on ........... 148

- - Fault on .................... 139, 179

- - Great conglomerato of........... 121

- - Greenstone group of ............ 133

_- Outer conglomerate of........... 131, 132

- - Southern range of............... 93

-

- - The greenstone of ... 107, 121, 131, 183, 186

- - Thickness of rocks of ............

- - Topography of ................. 123

- Series, Absence of rolcanic ash from... $\quad 100$

- A gate Bay group of ............116, 145, 187

$\ldots$ Alterations of diabase of........... 106

- - - olivinitic diabase of ........... 108

_, Amygdaloills of................... 110, 116

- , Amygdules of amygdaloids of ..... $\quad 117$

_- A northite rock of ................... 97, 105

- - A shbed-diabase of ................. 108

- A shbeds of ........................ 98

$\ldots$ A ugitc-syenite of ...............100, 111, 114

$\ldots$ Basic rocks of .................. 97, 101
Keweenaw Series, Chronologic relation of

eruptive rocks of................... 100, 128

- Classiflention of basic rocks of ..... $\quad 102$

- - Coarse gabbros of................. 122, 124

- Comparison of basic cruptives of, with those of the Huronian....... 172

-... Composition of .................. $\quad 97$

- Conglomerates of................. 98

-- , Contact of, with western sandstone in Douglas Connty, Wis.......... $\quad 150$

- Copper deposits of................ $\quad 180$

- C Cupriferous a mygdaloids of......... $\quad 181$

- conglomerates of ............... 180

- - veins of ........................ 183

- Detrital rocks of ................... 97,114

- - Diabase of ...................... 97

- Diabase-porphyrite of, described.... 108

- - Different views as to the relations of, to eastern sandsto ne............ 152

- Dikes of ....................... 100, 124

- Distribntion of upper dirision of.... 132

- Duluth group of .................. 134

- - Effect on topography of basic rocks of 123

- - Extent and general nature of ....... 95

- - Felsites of.................... 100, 111, 113

_- Fluidal texture in amy gdaloids of .. $\quad 118$

- - Formation of coarse gab bros of.... $\quad 125$

- - Gabbro of. ...................... 102, 104

- , General stratigraphy of........... 132

- -, Geologic position of............... 173

- - Granite of ......................100, 111, 114

- - Gra nitell of.................... 111, 114

- - Granitic porphyry of ...........100,111, 114

_- Hornblende-gabbro of ............. $\quad 105$

- - in Canada....................... 95

- - Indications of flowage in acid rocks of $\quad 120$

-,$-\ldots-$ basic rocks of .......... $\quad 120$

- in Michigan .................... 95

- - Minnesota .................... 95

- - the Nipigon Basin.............. 96

- Intrusive augite-syenite of.......... 125

- - - gran ite of...................... 125

- in Wisconsin..................... 95

- - Lateral extent of basic flows of..... $\quad 121$

- - Lava flows of .................. 97, 100

- - Lithology of ..................... 101

- Olivine-diabase of.................. 102, 107

- Olivine-free diabase of............ 106

- - Olivine gabbro of ................. 102

_-, Olivinitic diabase or melaphyr..... 107

- - on the north and east coasts of Lake Superior ................... 140

_- - south shore of Lake Superior .. $\quad 139$

- - Original acid rocks of............. 99,111

- , Origin of acid rocks of............. 130

$-\ldots,-$ basic rocks of............... 120

-, - coarse gabbro of .............. 125

-,- detrital rocks of ............. 100

- Orthoclase-free diabase of .......... 102

- Orthoclase-gabbro of............... 104

- - Proof of contemporaneonsness of basic rocks of.

121

- Pseudamygdaloids of .................. 106, 116

_-, Quartziferous porphyry of........99, 111, 113 
Page.

Keweenaw Series, Quartzless porhyry of. - - Relations of, to the Animikie gronp..............135, 157, 163 -, ,,$- \ldots$ associated formatious.... -,,-- - eastern sandstono........

- , - - - Huronian ............... ,,,,--- newer formations....... - Sandstones of .

- , Source of basic roeks of .......... - - - - detrital material of ............

- Stratiform amygdaloids of , Stratigraphy of lower clivision of...

- Structural features of detrital rocks of........................

-, - - three classes of rocks of ....

- - , relations of, to the Huronian in Nipigon Basin.

- - -, Summary riew of original rocks of..

- , Superposition of, on the Animikie

alates on Thunder Bay.

- - Thickness of beds of basic rocks of.

- - - lower division of ..............

- - - n upper division of ..............

- - Topographic effoct of basic rocks of.

-, Two divisions of....................

- - Warped bedding of lava flows of . .

King, Clarence, Administrative report of.

- cited in respect to terminal moraine.

- -, Work under direction of ...........

King, F. H., cited ...............357, 387, 398,400

Kinnicut, Robert, cited ................ 265

Knifo River, Minnesota ...............

Kutorgina minutissima................ 258, 259

- whitfieldi.

Laboratory facilities afforded by National Musenm and American Museum of Natural History

Lac La Belle, Micbigan................ 105, 150

Lacnstrine deposits associated with torminal moraine................298, 321, 329, 350

Lahontan, Lake. (See Lake Lahonton.)

- -, Lake beds of .....................

Lake Bonnerille, Extent of.

- Erio glacier, Western

- Lahontan, Bars and embank by...

- Chemical deposits of ................

- - Curre exhibiting the rise and fall of.

- - Dendritic tufa deposited by..........

- Desiccated bed of .................

- Desiccation products of.............

- Extent of ..........................

- , Fluctuations of ..................

- - Hydrographic basin of.

- - Investigations relating to...........

- - Lake-beds of. .......................

- - Lithoid tufa deposited by..........

- -, Many questions jet to bo asked of. . - Outlet of not found ................

_-, Orographic movements since epoch of .

- , Preliminary map of ................

- - Profile of the shore of ..............

- - Quateruary climatic oscillations recorded by

111

147

147

171

98

124

118

133

131

116

173

114

159

122

136

132

123

132

346

ii

5

\section{Laopteryx ..............}

Lapham, Dr. I. A., referred to ............. Latia dallii ...........................

Laurentian, Confnsed application of tho term, to rocks of the Lake Superior region..............................

Lara flows of Minnesota coast, Warped bedding of ..........................

Lea, Dr. Isaac, describes fossil Uniones .. Legs and foet of Hesperornis............ - - - Ichthyornis ................. Letter of transmittal of Director's report. Lenticular hills ....................... 306, 318 Leptona sericea ..................... $\quad 262$ Lestef River, Minn ................... 142, 145 - - group of Keweenaw Series ........ . 134 Lewis, H. C., cited .................302, 341, 346 Library, Need of a technical working.... x xii Limnoea (A cella) haldemani............ 445 - ? compactilis ....................... $\quad 445$ - (Limnophysa) nitidula.............. 445 - meekii ............................ 446 - minuscula........................ 446 -(Polyrhytis) kingii ................ 446 - shumardi......................... 446 - similrs ............................ 445

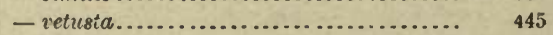
Limnæida .......................... 444 Linear topography...............321, 353, 361, 364 Lingula manticula ..................258, 259, 261 Lingulepis mara.................. 258, 259, 261 - minuta.........................258, 259, 261 Lioplacodes veternus ................. 406
List of illustrations .....................
,-- species..........................

Lithasia antiqua ................... 465 
Page.

212

Lithoid tufa in Lake Lahontan Basin ....

Locomotion of Hesperornis..............

Logan, Sir W., on the Animikie group....

$\ldots, \ldots$, referred to...... 153, 156, 159, 160, 169, 171

-, W. E., cited .......................

Lone Monntain dimestone ...............

Lower Coal-measure limestone of Eureka

District

- copper-bearing group ................

- division of Keweenaw Series, Stratig. raphy of .................

- - - , Thickness of ..............

Macfarlanc, James, cited............... .

Mac Fariane, T., referred to .........137, 138, 162

McKay's Mountain, Canada.............

MeKinlas, R., Work done by, on Soutl

Copper Range of Michigan.............

Macrocyclis spatiosa ....................

Macrodon teriuistriata

Mahogany Hills

Mamainse, Canada, Keweenawan rocks of. $\quad 124$

- - Thickness of Keweenawan rocks of. $\quad 138$

- peninsula, Lake Superior. .........124, 137, 178

Mammillary hills...................... $\quad 306$

Manitou Island, Lake Superior ......... $\quad 177$

- Rirer, Minn ...................... 144

Map of northern and central Nevada.... xvi

- - the Colorado Plateau region ....... $\quad \mathbf{x v}$

- - Ten Mile Mining District, Colo .. $\quad$ xvi

-, Preliminars, of Lake Lahontan....... 204

Mrargaritana nebrascensis .............. 427

Marsb, Prof. O. C., Birds with Teeth, by.. 45

Marvine, A. R., referred to............115, 139, 178

Mather, W. W., cited ................. $\quad \mathbf{3 8 0}$

Maumee glacier...................... $\quad 330$

Maxon, Rev. Dr..................... $\quad 371$

Mcek, F. B., cited ..................256, 259, 265

Melampus ? antiquus ................. 444

Melania claibornensis.................. $\quad 460$

- decursa ............................

-insculpta ..........................

- sculptilis...

- subsculptilis

- taylori..................................

Telanitacensis

Melaniidoe.

Melanopsis americana...................

Melaphyr of Keweenaw Series described.

Mesabi Range, Minn., Animikie group at.

--- , Drift relations of ................

- - Magnetitic rocks of ............

Mica in andesitic pearlites ...............

Michipicoten Island, Lako Superior...109, 114, 130 , $137,141,171,177$

- -, - , Thickness of Keweenawan rocks of..................

Micropyrgus minutulus.................

Minoral Point, Quartz porphyry of.......

Mineralogic differences between angite-

andesite and basalt...................

Minnesota Coast, A gate Bay beds of...116, 145, 187

_- Bearer Bay group of .............. $\quad 145$

_- Copper on...................... 187

$\ldots$, Dips and trends of rocks of ........
Minnesota Coast, Duluth group of .......

- - Great Palisades of

- - Identity of rocks of, with those of

Keweenaw Point...............

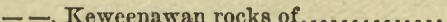

- , Keweenawan rocks of.............
- , Lester River group of............ 140

- - Stratigraphy of Keweenawan rocks of ........................... 144

- -, Temperance Rirer group of ........ 146

_- Thickness of Keweenawan rocks ui. $\quad 337$

- mine, Mich ...................... 181

- valley glacier.................... $\quad 388$

Mission Creek, Minn .................. 141

Missouri Cotean..................... 394

- Moraines of . ...................... $\quad 396$

Mode of eccurrence of volcanic rocks in

Eureka District.................... $\quad 280$

Modern lakes in Lake Lahontan Basin.... 203

Mohawk moraine ..................... $\quad 360$

Monographs by chief assistants nearly

completed......................... $\quad \mathbf{x v}$

Montreal River, Wis ........117, 119, 131, 136, 155,

$175,180,187$

Moraine, Altamont.................378, 388, 393

- of the Chippewa valley glacier........ 381

- - coast region .................. $\quad 380$

- - Dakota valley glacier .......... 393

- - Finger Lake region ..... ........ 353

- - Genesee glacier ................ $\quad 351$

- - - Grand River glacicr............ $\quad 341$

- - - Trarerse glacier............. $\quad 326$

- - Green Bay glacier............. 314

- - Hudson Valley glacier .......... 366

- - Lake Erio glacior, Western ..... $\quad 330$

- - - Michigan glacier ............. 322

- - - Superior glacier, Western.... 382

- - Maumeo glacier............... $\quad 330$

- - Minnesota valley glacier ......... $\quad 388$

- - Missouri Cotean .............. 396

- - Mohawk glacier................ $\quad 360$

- - Saginaw glacier ................ $\quad 327$

- - Scioto glacier ................ 338

- Terminal, of tho second glacial epoch,

by T.C.Chamberlis ............... 291

Moraines defined and classified ......... 301

-, General distribution of............. $\quad 313$

-, Intermodiato or intorlobate, defined .. 301, 313

- _ - described $315,323,328,330,339,341,351$,

$373,380,382,384,397$

-, Kettle, defined.................. $\quad 310$

-, Lateral ........................301, 352, 354

-, Medial........................ 301

-, Modifications of, in ridgerl regions.... $\quad 344$

-, Paper on....................... 291

-, Peripheral, defined ................ 302

-, 一, cited ......................336, 384, 400

-, Relatious of, to the margin of the drift. $\quad 314$

-, Terminal, defined................. $\quad 302$

- - described..................... $\quad 310$

,-- of the second glacial epoch ..........310,402

- , , Possible course of, veyond present explorations.....................

Morainic loops ..................... $\quad 313$

- -, Special descriptions of ........... $\quad 314$

- spurs in western New York .......... $\quad 348$ 
Morton,Dr.S. G., describes fossil Uniones. Mount Houghton, Keweenaw Point, Mich. - - , - - , Felsite of ............... Murray, Alexander, on the Huronian of

Lake Huron and Lake Superior..... 163, 169, 171

Myalina subquadrata..................

Mytilidae

Naiadites carbonaria ....................

- elongata

- lavis

National Museum,

of the

Neritidæ

Neritina bannisteri.

- bruneri .

- naticiformis .........................

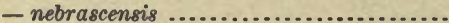

- (Velatella) baptista.....................

- bellatula

- carditoides

- volvilineata

Nevada limestone.....................

-, Map of northern and central..........

-, Niagara, limestone in................

-, Work in ...

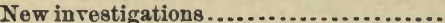

Newberry, Dr. J.S., cited ........ 331, 336, 339, 343

Newman, G. Olivio, Services performed

by ...............................

Niagara limestone in Nevada............

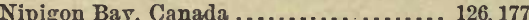

_ - , Thickness of Keweenawan rocks of...........................

- Straits, Canada.

Nonesuch belt, Mich

- cupriferous sandstone................

- silver-bearing sandstone..............

North shore of Lake Superior, Distribntion of Kewecnawan rocks on .....................

- - - - Distribution of rocks on...

- - - - Great exposures on ........

- - - Keweenawan rocks on ..... - - - - Scenic characteristics of.... Norwood, Dr. J. G., cited

, $-\ldots-$, on the geology of the Min. nesota coastof Lake Superior.118, 121, 124, 143

158,164

Numakagan Lake, Wisconsin $.134,165,175$

Obolella discoidea ..................... 259,261

Odontolcae .......................... 50,86

Odontornithes, Geologic horizon of ........

Odontotorma.

$50,69,86$

Office of the Survey, Location of the....

- work, Synopsis of .

Ogygia problematica

\section{- spinosa}

Olilest known birds

Olenellus abnormis

- barrandi

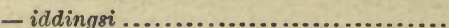

- thompsoni .........................

- vermontana.

- shales.

478

114

270

x vii

457

458

459

458

457

458

458

458

458

264

xvi

263

vi

$\mathrm{xV}$

243

263

137

129

180

185

143

141

140

140

140

385
Page.

130

(1)

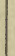

-

(

Petit Marais, Minn...................

Phillipsia (sp. १).........................

Physa bridgerensis...................... - carletoni.............................

- copei..................................

- felix

- pleromatis.............................

Physidx............................. 449

P'ic River, Canada ....................... 177

113 Pigeon Point, Minn., Animikie rocks of.. 141, 158

49 - - - Dikes of .................... 158

256 - River, Minn......................... 117, 130, 137

256 Pin̄on Range, Devonian limestone of..... 267

256 Pinto fault............................. 289

$257 \quad$ -, Volcanic rocks of ................ $\quad 280$

257 - Peak, Altitude of................... 240

$256,257 \quad \ldots$, Rhyolite of .................... 279, 282 
Pisidium saginatum.....................

Plains marginal to moraine...303, 321, 324, 329, 340 ,

Planorbis cequalis

355,378

- (Bathyomphalus) amplexus .........

- - kanabensis.

- planoconvexus

- cirratus

- convolutus.

- (Gyraulu

militaris

- leidyi.

- lunata..................................

- nebrascensis

- utahensis

- - var. spectabilis

- veternus

- vetustus.

Plant improssions in White Pine shale...

Playa lakes

(Pleurolimnaca) tenuicostata .............

Pleurotomaria sp.?

Pogonip limeston

Pointe anx Mines, Lake Supe

Poler

,,--- Animikio Group at.............

,,-- Magnetitic quartzite of .........

Polypora sp.?

Poplar River, Minn .................. 126, 144

,,-- Felsitic porphyries of...........

Porcupine Monntains, Mich..

.,-- , Faults in ......................

-, Folsite of .................. 114, 139

$\ldots,-$, Relation of the, to Koweenawan gynclinal ...

175,186

,,-- Structure of ................. 130, 139

-, , Topography of................ 123

Portage Lake, Mich ......121, 123, 150, 151, 180, 181

Post-Lahontan orographic movements.... 232, 233

Potato River, Wis....................

Potslam sandstone of the Mississippi

$$
\text { Valley }
$$

Power of flight of birds .................

Preliminary paper on the terminal moraine, by Prof. T. C. Chamberlin........

Productus hallianus

- prattenianus.

- punctatus...........................

- semircticulatus.

- shumardianus

P.

- - the Lahontan lithoid terrace (Fig. 47)

Prospect Mountain limestone ...........

- - quartzite..........................

- -, Rhyolito dikes of .................

- Peak, $\Delta$ ltitude of....................

- Ridge ...........................

Protospongia fenestrata ................

Prygulifera humerosa.................

Pseudamygdaloids of Keweenaw Series described .........................

Psilophyton in White Pine shale. ........

Ptilodictya carbonaria..................

- serrata.
Ptychaspis minuta .................. Page.

Publications, Exchange of, provided for xv by law ........................ xvii

-, Preparation of.......................

Pumpell 5, R., referred to.115, 117, 129, 151, 153, 178,

181,184

- - Studies of the copper-bearing rocks

of Lake Suporior by .................93, 106, 111

Pupa arenula ....................... $\quad 456$

- atavuncula ....................... 450

- bigsbyi.......................... 456

- incolata........................... 450

- vermillionensis..................... $\quad 456$

- vetusta.............................. 456

Pupidro ............................ 455

Quartz in basalt..................... $\quad 280$

Quartz-porphyry, Agø of.............. 274

- - Eureka District.................. 273

- of Keweenaw Sories ............... 113

Quartzless-porplyyries of Kowcenaw Series described ......................... 112

Quaternary climato recorded by Lake Lahontan....................... 230

- furmations, Classification of ......... 295

- lakes of the Great Basin, Study of the. xvi

Raer.............................. 299

Rainfall a potent factor in any region.... 199

- of the Great Basin.................. 196, 199

Rainy Lake, Crystalline schists of ...... $\quad 169$

Real, M. C., cited.................... 341, 342

Real, Thomas J., $\Delta$ id rendered by....... 243

Receptaculites mammillaris............. . 201

Reconnaissance, A geologic, in Nevada, California, and Oregon ...............

Relative arge of augite-andesito and basalt ............................ 284

- - - - - rbyolite............... 284

- - dacite and rhyolite.............. $\quad 283$

- - rhyolito and basalt .............. 284

- - - volcanic rocks of Eureka District. 281, 284

Remains of birds rare................. 49

Report, Administrative, of Clarence King 3

,,$---\Lambda$ rnold Hague ............... 10

,,--- G. K. Gilbert ................ 14

,,-- T. C. Chamberlin............ 17

,,-- S. F. Emmons ............... 22

,,--- G. F. Becker ................. 2 .

,,--- L. F. Ward ................. $\quad 26$

,-- J. Howard Goro .............. $\quad 30$

,,--- Gilbert Thompson ............ 32

Report of the Director................ $\quad \mathrm{xv}$

Reptiles, Birds related to.............. $\quad 51$

Roptilian aucestry of Hesperornis ....... $\quad 66$

- features of Ichthyornis .............. $\quad 79$

Rescue Cañon, Rhyolite of.............. 279, 282

- Hill, Deronian of.................. 265

Restoration of Hesperornis............. 64

- Ichthyornis...................... 77

Retzia mormoni...................... $\quad 270$

460 Reviow of the non-marine fossil mollusca of North America by D1. C. A. Whito.. 403, 550 Rhynchonella castanea ................ 265, 266 - eurekensis ......................... 209

270 Rhyolite, Eureka District.....277, 279, 281, 284, 289 
Page. 277,284

Rhyolite-pumice.

Rhytophorus meekii.................... - priscus.

Ribs of Hesperornis ...................

Richmond Mine, Cambrian fossils in limestone of

- Mount, Altitude of ...................

- -, Augite-andesito of.

Rickard, R., Aid rendered by .............

Rise and fall of Lake Lahontan, Curre exhibiting the (Fig. 51) ..................

Rissoidæ.

Roberts Peak Mountains, Deronian limestone of ............................

Rominger, Carl, cited.

- - , referred to

Ruby Hill, Magnesian limestone of........

- -, Mines of........................

_-, Prospect Mountaln, quartzite of....

_., Rhyolite of ..

Russell, I. C., Sketch of the geologic history of Lake Lahontan, by ......

-, - - Work of....................

Saganaga Lake, Crystalline schists of....

Saginaw glacier .......................

Saint Croix River, W is ................ 174, 177

_- - Kowernawan rocks of...123, 133, 137, 156

- Valley, Wis..................... 187

- - - - Copper in................. 187

— Ignace Island, Lake Superior ........ 126, 176

- John's ridge.

332,338

- Louis River, Minn $105,137,141,144$,

162,175

,,--- , Animikie group on............

$-\ldots,-$, Coarse gabbro of .

142,144

-,-- , Gabbro dikes in slate of ......

,,--- , Red porphyries of ............

$\ldots,-$, , Rejations of Koweenawan and Huronian rocks on...........

- - , - Slates of ................137,

- Mary's ridge

142

- River, Minn .....................

Salive deposits of Lake Lahontan ........

Salinity of Great Salt Lake..............

- the Dead Sea .....................

Salisbury, R. I., cited .........350,357,360,375

Salt-works in Lako Lahontan Basin..... 225, 228

Salts in Lake Lahontau Basip ........... 224, 230

Saud Spring Salt Works............... $\quad 227$

Sandstones of Kewreenaw Series......... 98

Sault Ste. Marie ...................... 140, 170

Scapular arch of Hesperornis ...........

- - Ichthyornis ..

Scenella conica ........

Schell Creek Range, Pogonip limestone of

Schizodus cuneatus

Scioto glacier.

Secrot Canon shale.....................

Section, Gencralized, of bank of Truckeo Rivcr vear Iudian A gency ...

-, - , - a tafa dome of Lake Lahontan Basin (Fig. 50) ................

-, Ideal, illustrating cañons of Corson River (Fig. 53) ...................

-, -, of a spring deposit (Fig. 49) .......
Section, Ideal, of Basin Range Structure (Fig. 44)...........................

- illustrating the relations of the Laliontan tufas (Fig. 48) .................. - of Quaternary strata at Mill City, Nov.

(Fig. 52) ......................... - - reservoir and vats ar Eagle Salt Works, Ner. (Fi... 54) ............ Sedimentary deposits in Lake Lahontan. 221, 224 Selwyn; A. R. C., referred to ............ 124 Shells of fresh-water gasteropods in Lako

Lahontan deposits ................213, 221, 223

Shore currents, W ork of............... 207

- drift, Nature of..................... 207

- embankments, Ideal plat illustrating (Fig. 46) ......................

- T The formation of .................. 200

Sierra Cañon, Dacite of ................. Silica in augite-andesite, Percentage of .. $\quad 287$ Silurian rocks, Eureka District .......... $\quad 260$ Silver Creek, Minn .................. $\quad 110$ - Islet Landing, Canada ............... 160 - Mine, Canada.................. 161 - Monntain, Mich ................... $\quad 139$ Silrerado and County Peak group ....... 250 Size of Hesperornis.................... 65 Sketch of the geologic listory of Lake

Lahontan, by I. C. Russell.............. 189 Skull of Ichthyornis ................. $\quad 70$ Smock, J. C., cited .............302, 343, 346, 369, 377 Suake River, Minn .................... 187

Soils near Denver studied............. xvi South copper range, Mich......... 122, 147, 152, 155 - shore of Lake Superior, Kewcenawan rocks of ..................... - $-\ldots$, Scenic characteristics of ...

Sphoerium formosum.................. 439 -idahoense.......................... 440

- planum........................... 439

- recticardinale...................... 439

- rugosum......................... 440

- subellipticum ....................... 439

Spirifera camerata................... 269

-maia .............................. 266

- piñonensis....................... 206

- subumbona....................... 266

Split Rock River, Minn,......105, 116, 113, 145, 177

Spring deposit, Irleal section of a (Fig. 49) 219

- Hill, Carboniferous fauna of........... 269

Spurious and doubtful species........... 478

Stannard's Rock, Lake Superior .113, 139, 177, 179

- -, Quartzless porphyry of .......... 139

Stenolheca elongata.................... 258

Sterenson, J. J., cited .................. 343

Stratiform amygdaloids of Kereunaw

Series described ................... 118

Streptorhynchus chemangensis .......... 206

- crenistria ......................... 269

Striation, Glacial, in Dakota ........... $\quad 399$

$223-\ldots,-$ Finger Lake r......n ........... 358

-, -, - Grand River region ........... 342

-, -, - Green Bay rogion ............ $\quad 318$

-, - - IIuldson (wostorn) region....... 374

$224 \quad-,-,-$ Lake Michigan rogion ........ 325

219 -,- - Supcrior regiou............ 387 
Striation, Glacial, in Maumee region.....

-, -, - Minnesota Valley .............. ,,--- Mohawk Valley.

,,--- Scioto region..........................

Stromatopura (sp. ?)

Strong, Moses, cited ..........

-, _, on the copper-bearing rocks of

Lake Superior .....................03, 174, 175

Strophites grandaeva

Strophodonta perplana...................

Structural differences between augiteandesite and basalt...............

- - in granite-porphyry.

Styliola fiseurella ...s.

Subaqueous till...297, 324, 329, 331, 336. 351, 355, 360,

$362,383,386,392$

Snb-glacial till 296,321

Succinea (Brachyspira) papillispira ......

Succinidæ...........................

Superglacial till.

Swcet, E. T., cited

- - on the copper-bcaring rocks of

Lake Superior............93, 139, 174, 175

Synclinal of Lake Superior...............

- - - between Isle Royale and $\mathrm{Ke}$ weenaw Point ..............

- - - in northern Wisconsin.........

Synopsis of field and office work

Syringopora perelegans ..................

Tail of Hesperornis.

- Ichthyornis

Taylor, F. W., Chemical analyses of brines

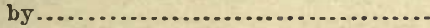

Teoth, Birds with

- of Hesperornis.

\section{- - Ichthyornis.}

Tellimanya contracta.

Temperance River group of Koweenaw Series

Ten Mile Mining district, Colorado, In vestigations in ...........

_- - , , Topographic map of........

Terminal moraine, Paper on

Terrace and sea cliff, Profile of a (Fig.45).

-, Profile of the Lahontan Lithoil (Fig.

$$
\text { 47) .. }
$$

Terraces. .303 ,

- and embankments, The formation of..

- cut by Lako Lahontan................

- - - - ; what they teach.

- on tho coast of Australia

Tertiary and post-Tertiary volcanic rocks

of Eureka District ...................

Thaumastus limnoiformis.

Thickness of paleozoic rocks of Euroka District .

- - - Kanab Cañon .............

- - - - Wahsatch Range...........

Thinolite in Lake Lahontan Basip .......

Thinolitic tufa in Lake Lahontan Basin..

Thompson, Gilbert, Administrative re-

$$
\text { port of . }
$$

- - Geodetic and topographie work of.

Thompson, Minn., Animikie slates at....

$x v i$

xri

291

206
Thunder Bay, Canada Rage.

ks of.......135, 141, 158 ,-- , Sandstone of................ 35 - -, Lake Superior, Dikes of.......... $\quad 158$ - - region, Coarse gabbro of........... 144 - Cape, Lake Superior.................. 159 Till classified ...................... 290 -, Subaqucons, berg or floe..297, $324,329,331,336$,

$351,355,360,362,383,386,392$ -, Snbglacial .................... 296, 321 —, Superglacial, englacial, or upper ..... $\quad 297$ Todd, J. E., cited ................. 395, 397, 400 Topographic relations of the Grand River moraine ....................

- - - Green Bay moraine ........... - - - Lake Michigan moraine........

- - - Maumce moraine..............

- - - Minnesota moraine............

- - - Saginaw moraine..............

- - - Scioto moraine...............

- types, Åsar ........................

-, , Boach ...........................

- - classified .........................

- - Drainage-erosion .................

- - , Dune. .........................

- - Fluviatile ......................

- -, Glacio-erosion .....................

- - Kame .........................

- - Lacustrine

- -, Lenticular ...................306, 318, 321

- - , Linear .............306, 318, 321, 353, 361, 364

— - Mammillary ..................... 306, 32i

- -, Marine....................... $\quad 308$

- - Morainic ..................... 307

- , Orographic...................... 305

- - Till ........................ 306

Topography of eastern Dakota ......... $\quad 393$

- - shores ....................... 304

Torch Lake, Keweenaw Point ......... 149, 151

Torrell, Otto, cited ................... $\quad 297$

Towers and domes of tufa built by Lake

Lahontan.

Trains of bowlders.....................

Treasure Ilill, Deronian limestone of ....

Trenton limestone in the northern penin. sula of Michigan ..................

- species in the Lone Mountain limestone. - - - Pogonip....................

Trilymite in angite-andesite............ Trinucleus concentricus .................. Tuculit Mountains, Deronian fishes of .. - - - limestone of ................... Tufa deposits of hot springs ............ - - Lako Lahontan................. - - - - Section illustrating the relations of the (Fig. 48) ...

8

9

1

97

342

316

323

333

389

329

339

308

304

305

308

09

305

.

\begin{tabular}{l}
1 \\
8 \\
7 \\
6 \\
3 \\
1 \\
7 \\
\hline
\end{tabular}

- from Lake Lahontan Basin, Analyses of . ...................................

-, Physical conditions favorable to forma. tion of - towers and domes built by Lake La.

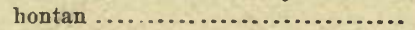

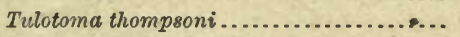

Tyler's Fork, Wis.................... 114 
Page.

Unconformity at top of Eureka quartzite. 262, 267

Unio clavus...........................

- aldrichi .............................

- belliplicatus.......................

- brachyopisthus

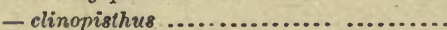

- coucsii

- cristonensis

- cryptorhynchus.

- deveyanus

- endlichi.

- goinonotus

- goniambonatus.

- haydeni.

- holmesianus .........................

- hubbardi.

- mendax............................

- mucalis

- penultimus.

- primaevus

- proavitus

- propheticus

- senectus.

- shoshonensis

- stevoardi

subspatulatus

- tellionoides.

- vetustus.

- vashakiensis

Unonidx

Upham, Warren, cited .......302, 346, 377, 378, 380, $383,384,387,388,392,39$

Upper Coal-measure limestone of Eureka District ..........................

- dirision of the Keweenaw Series.......

Valley drift.......302, 321, 350, 352, 355, 357, 360, 382

Valleys of the Great Basin occupied by

Quaternary lakes.

Valvata? montanaensis

- inana

- iscabrida .

- isubumbilicata.

Valratida

\section{1}

430

433

434

432

425

431

431

432

433

4.33

435

433

427

433

426

427

432

432

433

433

432

435

420

431

435

430

435

424

Vanuxem, Larned, cited .............. 352, 357, 364

Vermillion Lake, Minn.,Crystalline schists of..

Vormont, Georgia slates of..s...........

Vertelbre of Hesperornis.

- Ichthyornis.

V(rtebral forms, Origin of.................

Vitrina obliqua........................

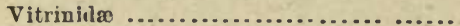

Viviparida

Viviparus conradi

(

- gillianus

- leai.

- leidyi rar. formosa

- paludineaformis.

- panguitchensis.

- peculiaris.

- plicaprissus

- prudentius.

- retusus
Viviparus reynoldsianus

Page.

467

- trochiformis.......................

-wyomingensis .......................

Volcanic rocks of Eureka District, $\Lambda$ go of.

Volsella (Brachydontes) laticostata........

- - regularis.

Wadsworth, M. E., on the relation of eastern sandstone of Lake Superior to the Keweenaw Series .........

154

-, - 一, referred to..................150, 153, 154

Wahsatch Range, Paleozoic section of .. 271

Walcott, Charles D., cited........ .257, 265, 269, 272

-, - , on Devonian fishes in Kanab Cañon $\quad 265$

_, - , Paleontology of the Eureka Dis-

trict, by ......................... . 242

W ard, L. F., Administrative report of...

- - Paleontologic work of ...........

Wave action on shores...................

Wober conglomerate of Eureka District.

Western sandstone at Fond du Lac, Minn

- - of Lake Superior.................

- $-\ldots$, Contact of, with Kowoenaw Series in Douglas Co., Wis.

- - - - Equivalency of the, with the eastern sandstono........

- $-\ldots$, Relation of the, to the Koweenaw Sories.........

- - - - - - , - Misslssippi Pots. dam ...........

26

xvi

206

270

141

155

156

150

White, Dr. C. A., cited ................. 259, 269 - _ - - in respect to terminal moraine................. 389, 392

- $-\ldots$, Collection of invertebrate fos. sils by .....................

- - . Review of the non-marine fossil mollusca of North America by .................. 403

- I. C., cited................... 343, 372, 373

White Cloud Peak, Altitude of ......... 246

- Pino shale....................... 206

Whitfield, R. P., cited................... 269 Whittlesey, C., cited . ........... 310, 336, 339, 384 Wirhman, A., on the microscopic charac-

ters of the Menomince Hurunian ...... 107

Williams, J.S., cited................... 333

-, Prof. II. S., cited ................... $\quad 359$

-, Prof., aid rendered by .............. 371

Wilson, G. H., Services performed by .... 243

Winchell, A., cited .............. 326, 329, 334 -, N. II., vited ............. 330, 332, 3:33, 336, 383 _- , r' ferred to. $118,123,126,158,161,164,169,171$

Wings of Hesperornis ................. 59 - Ichthyornis ...................

Wisconsin geological surrey ........... $\quad 93$

- River Valley, Crystalline schists of.... 171

Woodpecker's P'rak, Altiturle of ......... 246

- - Deronian of ................... 265

Wooster, Pruf. L. C., cited .......... . 3ะ3, 325, 310

Work of chief grologic assistants ........ $\quad x v$

Wright, G. F., cited ..........302, 341, 346, 317, 380 Zaphrentis (sp. ?) ..................... 270

Zircon in angite-andesito............... $\quad 278$

- - rhyolite......................... $\quad 279$

Zirkel, Prof. Ferdinand, cited........... $\quad 285$

Zonites priscus ...................... 453 





\section{RETURN EARTH SCIENCES LIBRARY}

TO $\Rightarrow 230$ Earth Sciences Bldg. 642.2997

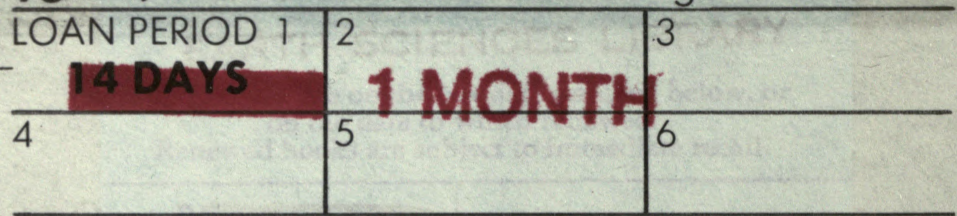

ALL BOOKS MAY BE RECALLED AFTER 7 DAYS

Books needed for class reserve are subject to immediate recall

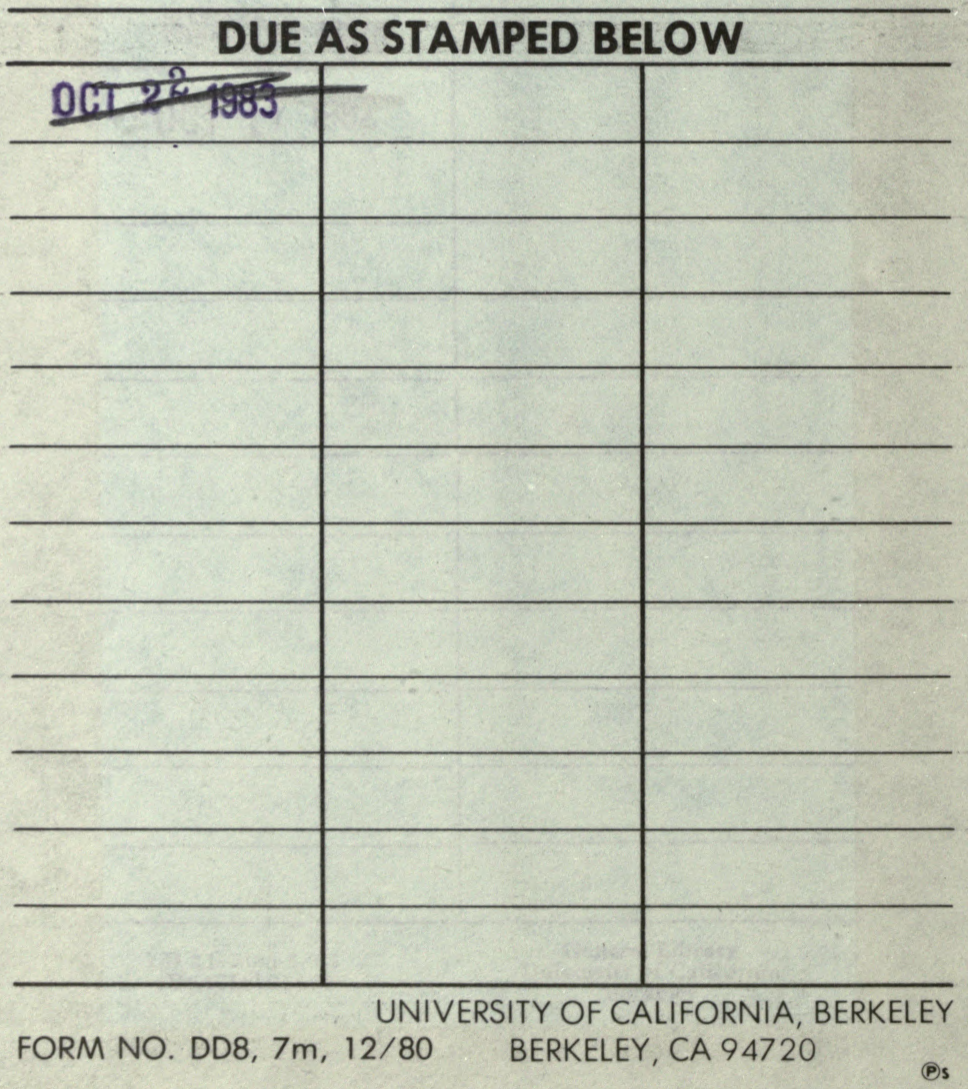


storage

781 
